\title{
Arquitetura e domínio técnico: a prática de Marcos Acayaba
}

Tatiana Midori Nakanishi

Dissertação apresentada à Escola de Engenharia de São Carlos da Universidade de São Paulo, como parte dos requisitos para a obtenção do título de Mestre em Arquitetura e Urbanismo

Orientador: Prof. Dr. Márcio Minto Fabrício

São Carlos 
AUTORIZO A REPRODUÇÃO E DIVULGAÇÃO TOTAL OU PARCIAL DESTE TRABALHO, POR QUALQUER MEIO CONVENCIONAL OU ELETRÔNICO, PARA FINS DE ESTUDO E PESQUISA, DESDE QUE CITADA A FONTE.

Ficha catalográfica preparada pela Seção de Tratamento da Informação do Serviço de Biblioteca - EESC/USP

Nakanishi, Tatiana Midori
N163a Arquitetura e domínio técnico : a prática de Marcos Acayaba / Tatiana Midori Nakanishi ; orientador Márcio Minto Fabrício. -- São Carlos, 2007.

Dissertação (Mestrado-Programa de Pós-Graduação em Arquitetura e Urbanismo. Área de Concentração: Arquitetura, Urbanismo e Tecnologia) -- Escola de Engenharia de São Carlos da Universidade de São Paulo, 2007 .

1. Arquitetura - técnicas. 2. Domínio técnico. 3. Soluções construtivas. 4. Prática profissional. 5. Marcos Acayaba. I. Título. 
Aos meus pais, por todo o amor que sempre me deram e pela confiança que depositaram em mim nesses anos de muitas conquistas. 


\section{AGRADECIMENTOS}

Essa pesquisa é resultado de uma reflexão iniciada ainda no período de graduação e que se estenderá por toda minha vida profissional, no intuito de manter em minha atividade, a terna curiosidade de uma criança em descobrir o mundo em todas as respostas que ele contém.

Muitas pessoas me ajudaram nesse caminho, por isso agradeço:

Ao meu orientador, Márcio Minto Fabrício, pela dedicação, paciência e incentivo para transformar minhas angústias em pesquisa.

Aos professores, João Marcos de Ameida Lopes e José Mário Nogueira Carvalho Jr., por compartilhar seus conhecimentos em minha banca de qualificação, contribuindo muito para o desenvolvimento desse trabalho.

Ao arquiteto Marcos de Azevedo Acayaba, ao engenheiro Hélio Olga de Souza Jr. e seu auxiliar, Marcus Vinicius Barreto Lima, por todo o material cedido e pelo tempo dedicado em me atender em inúmeras visitas e telefonemas.

Aos professores que me ajudaram a enxergar coisas que meus olhos não estavam acostumados a ver: Prof. Dra. Akemi Ino, Prof. Dr. João Marcos de Ameida Lopes, Prof. Dr. Miguel Antônio Buzzar, Prof. Dr. Mounir Kalil El Debs, Prof. Dra. Rosana Maria Caran, entre outros.

À Elena Gonçalvez, pelo auxílio com as regras de informação e documentação.

À Capes, pelo financiamento desta pesquisa.

Por fim, agradeço também a todos os meus amigos, cujos abraços e sorrisos me fazem ter forças para seguir traçando meus caminhos na busca de algumas respostas. 
RESUMO

\begin{abstract}
A importância do domínio técnico na arquitetura vem sendo debatida desde meados do século XVIII. Apesar disso, verifica-se na atuação de muitos arquitetos contemporâneos uma deficiência no desenvolvimento e detalhamento de soluções construtivas. A pesquisa objetiva estudar a relação do arquiteto com a questão da técnica, desde o início do processo projetual até a obra construída, a partir da experiência do arquiteto Marcos Acayaba, que se destaca por desenvolver soluções conceituais e espaciais intimamente atreladas a um rigoroso tratamento técnico, transitando por diversos materiais e sistemas construtivos. O método de pesquisa abrange levantamentos bibliográficos e documentais referentes à atuação do arquiteto e ao desenvolvimento de oito projetos cujas soluções construtivas são descritas e analisadas através de dados coletados em visitas às obras e entrevistas com Acayaba e seus parceiros profissionais. Como resultado, aponta fatores determinantes na formação e na atividade do arquiteto que, embasados pelos estudos detalhados dos projetos e seus recursos construtivos, demonstram que o domínio técnico pode ser um importante instrumento para o pensar e o fazer arquitetônico.
\end{abstract}

Palavras-chave: Arquitetura; Domínio técnico; Soluções construtivas; Prática profissional; Marcos Acayaba. 
ABSTRACT

The importance of the technical domain has been discussed since the middle of the seventeenth century. Although, we can see some deficiency at the development and at the construction solution's detailing on the performance of several contemporary architects. This paper intends to study the architect's relationship with the technique itself, since the beginning of the design process until the constructed building, starting from the architect Marcos Acayaba's experience, who outstand for developing conceptual and space solutions strongly connected to a rigorous technical treatment, transiting among several materials and building systems. The research's method includes bibliographical and documental survey referring to the architect's performance and the development of eight design projects which the construction's solutions are described and analyzed through collected data that come from visits to construction places and interviews with Marcos Acayaba himself and his professional partners. As a result, this paper points determinant factors on the professional formation and the architects' activities, that based on the last studies detailed on the projects, their building resources show that the technical domain might be an important instrument to the thinking and the caring through of the architect.

Keywords: Architecture; Technical domain; Construction's solutions; Professional practices; Marcos Acayaba. 


\section{SUMÁRIO}

\section{RESUMO}

\section{ABSTRACT}

$\begin{array}{ll}\text { 1. Introdução } & \text { p. } 9\end{array}$

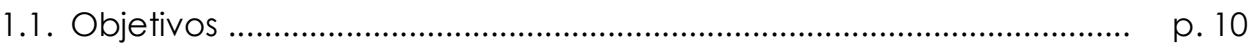

1.2. Método de pesquisa …........................................................................ p. 10

1.3. Estrutura do trabalho ............................................................................ p. 13

2. Contexto P. 15

2.1. Arquitetura, técnica e tecnologia ....................................................... p. 15

2.2. Breve contexto da arquitetura no Brasil pós 60 ................................... p. 21

$\begin{array}{ll}\text { 3. Marcos Acayaba } & \text { p. } 27\end{array}$

3.1. Formação, referências e parcerias …..................................................... p. 29

3.2. Formas de estudo e representação de projeto …………..................... p. p. 30

4. Residência Milan (São Paulo - SP, 1972-1975)

4.1. O projeto …….................................................................................... p. 42

4.2. A solução construtiva: Casca em concreto armado .......................... p. p. 46

4.3. Considerações sobre o projeto .............................................................. p. p. 55

4.4. Ficha técnica .................................................................................... p. p 56

5. Fazenda Pindorama:

Casa-sede e Pavilhão (Cabreúva - SP, 1974 e 1984)

5.1. O projeto - Casa-sede ....................................................................... p. p. 58

5.2. A solução construtiva: Abóbadas de blocos de concreto ................ p. p 61

5.3. O projeto - Pavilhão ............................................................................ p. 67

5.4. A solução construtiva: Parede de tijolo e concreto ………………..... p. p. 72

5.5. Considerações sobre os projetos ………….......................................... p. p. 78

5.6. Ficha técnica-Casa-sede .................................................................... p. p. 79

5.7. Ficha técnica - Pavilhão ........................................................................... p. p. 80 
$\begin{array}{lll}\text { 6. Residência Hélio Olga (São Paulo - SP, 1987-1990) } & \text { P. } 81\end{array}$

6.1. O projeto

p. 82

6.2. A solução construtiva: Estrutura em madeira pré-fabricada em terreno de alta declividade

6.3. Considerações sobre o projeto

p. 102

6.4. Ficha técnica

p. 103

7. Residência Baeta (Guarujá - SP, 1993-1994)

Residência Marcos Acayaba (Guarujá - SP, 1996-1997)

p. 105

7.1. O projeto - Residência Baeta

p. 106

7.2. O projeto - Residência Marcos Acayaba

p. 114

7.3. A solução construtiva: Estrutura em madeira pré-fabricada com base modular triangulada

7.4. Considerações sobre osprojetos

p. 132

7.5. Ficha técnica - Residência Baeta

p. 133

7.6. Ficha técnica - Residência Marcos Acayaba

p. 134

8. Escola Estadual Jd. Bela Vista II (Mogi das Cruzes - SP, 2003-2005)

p. 135

8.1. O projeto

p. 136

8.2. A solução construtiva: Duas funções para elemento em concreto pré-moldado

p. 141

8.3. Considerações sobre o projeto ……................................................. p. p. 149

8.4. Ficha técnica ................................................................................. p. 150

$\begin{array}{ll}\text { 9. Vila Butantã (São Paulo - SP, 1998-2004) } & \text { p. } 151\end{array}$

9.1. O projeto

p. 152

9.2. A solução construtiva: Laje nervurada em concreto e madeira .....

p. 160

9.3. Considerações sobre o projeto

p. 167

9.4. Ficha técnica

p. 168

10. Considerações finais

p. 169

BIBLIOGRAFIA

p. 172

ANEXO A - Texto escrito por Acayaba sobre sua metodologia de trabalho

p. 178

ANEXO B - CD-ROM - Entrevistas com Marcos Acayaba e Hélio Olga 


\section{CAPÍTULO 1:}

INTRODUÇÃO

O distanciamento dos arquitetos das questões técnicas é um fenômeno que alguns historiadores afirmam ter se iniciado ainda na Renascença. Foi alvo de fortes críticas pelos arquitetos modernistas no início do século vinte, mas até hoje continua contaminando imagem da profissão. No Brasil ainda é comum a idéia de que cabe ao arquiteto somente as questões estéticas, e que as questões da construção ficam a cargo do engenheiro, creditando àquele uma função erroneamente supérflua e secundária.

O arquiteto é quem define as diretrizes, formas e materiais do edifício. Sua atuação interfere diretamente nos índices de impacto ambiental, economia, conforto, durabilidade e funcionalidade da construção. Ressalte-se portanto a importância do conhecimento técnico que, além de tudo, pode consistir num importante instrumento de criação, ampliando as possibilidades não só do fazer, mas principalmente do pensar arquitetônico.

Isso se vê na atuação do arquiteto Marcos de Azevedo Acayaba, em que o diálogo entre as áreas técnicas específicas e seus profissionais (estruturas, instalações, conforto ambiental, entre outros) costuma ser corrente ao longo dos processos projetuais, além disso, seus projetos se destacam pela grande variedade de materiais e técnicas construtivas, desde as tradicionais, como a alvenaria estrutural, até as industrializadas, como as estruturas pré-fabricadas em madeira e concreto. 
Capítulo 1

Introdução

\subsection{Objetivos}

A pesquisa tem como objetivo estudar a relação do arquiteto com a questão da técnica, desde o início do processo projetual até a obra construída, por meio do estudo da atuação do arquiteto Marcos Acayaba e de oito projetos que se destacam por suas inovações construtivas e formais.

Visa-se produzir um estudo detalhado dos processos e das soluções projetuais sob o ponto de vista técnico-construtivo dos edifícios, verificando as relações entre as premissas projetuais de cada caso e as soluções técnicas adotadas, contextualizando seu desenvolvimento e investigando a prática do arquiteto.

Por fim, através do caso particular da atuação de Marcos Acayaba, busca-se demonstrar como o domínio técnico contribui, e não limita, a capacidade dos arquitetos em desenvolver criativas soluções formais e espaciais.

\subsection{Método de pesquisa}

Primeiramente foi realizada uma revisão bibliográfica baseada em dois veios de investigação. O primeiro, com um caráter mais histórico visava realizar um breve panorama sobre o contexto em que se inserem a formação e a atividade profissional de Acayaba. O segundo, com caráter mais tecnológico, visava fornecer subsídios para as análises das técnicas e das tecnologias empregadas nos projetos. A revisão foi realizada com consulta a livros, periódicos, teses e publicações em geral.

Foram feitas, a partir daí, descrições de oito obras realizadas ao longo da carreira do arquiteto, escolhidas em função de suas inovações, técnicas e datas de projeto, possibilitando criar um panorama geral de sua prática profissional. O levantamento dessas obras se deu ainda durante o processo de 
Capítulo 1

Introdução

revisão bibliográfica. Dentre as oito obras, não por acaso, cinco são de residências unifamiliares. Isso se deve ao fato de que, "[...] na procura de novas linguagens, técnicas e materiais, Acayaba acredita que a arquitetura de residências aparece como campo aberto à experimentação" (PEDREIRA, 1986, p.58), pensamento que reflete diretamente em sua produção arquitetônica.

Desde o início da pesquisa, foram realizadas entrevistas com Acayaba e visitas ao antigo escritório (fechado) e ao atual estúdio de criação, em sua residência.

As entrevistas foram elaboradas com base na fundamentação teórica e nos conhecimentos obtidos a partir dos estudos bibliográficos/ iconográficos e, abordam questões referentes ao processo projetual, conhecimentos técnicos e de construção.

Foram também realizadas visitas aos edifícios analisados na companhia do arquiteto, dentre as quais: residência Milan (atual residência do arquiteto) e conjunto residencial Vila Butantã, em São Paulo-SP; residência Baeta e residência Marcos Acayaba, no Guarujá-SP.

Essas visitas foram de grande importância para a pesquisa, pois revelaram detalhes e intenções, difíceis de obter apenas por meio de materiais iconográficos.

No estúdio, foram coletados cópias de projetos, imagens e memoriais, obtendo dados referentes a: programas de necessidades, estudos de viabilidade e modos de desenvolvimento do projeto, diretrizes básicas, técnicas construtivas, estrutura, projetos complementares, ferramentas de estudo e desenvolvimento de projeto e interface projeto-obra.

Foi realizada também uma visita à residência e ao estúdio do engenheiro Hélio Olga de Souza Júnior, parceiro de Acayaba em diversos projetos. Nessa ocasião, realizou-se uma entrevista com o engenheiro, abordando assuntos referentes à sua atividade profissional e às soluções construtivas adotadas nos projetos. 
Capítulo 1

Introdução

Também foi realizada uma visita à Escola Jardim Bela Vista II, em Mogi das Cruzes - SP, e consulta ao engenheiro Ruy Franco Bentes, responsável por seu projeto estrutural.

O material obtido nas visitas e nas entrevistas permitiu a consolidação dos estudos detalhados das soluções técnicas adotadas nos projetos. Para a elaboração dessa etapa foram feitas investigações bibliográficas especificamente relacionadas aos sistemas construtivos analisados e consultas a especialistas em cada área: Prof. Dra. Akemi Ino, EESC-USP - Escola de Engenharia de São Carlos da Universidade de São Paulo (sistemas construtivos em madeira); Prof. Dr. Mounir Khalil El Debs, EESC-USP (concreto pré-moldado); Prof. Dr. João Adriano Rossignolo, EESC-USP (concreto); Prof. Dra. Rosana Maria Caran, EESC-USP (conforto térmico de edificações); Prof. Dr. João Marcos de Almeida Lopes, EESC-USP (projeto e estruturas). E para o levantamento bibliográfico relacionados às questões históricas também foram consultados: Prof. Dr. Miguel Antônio Buzzar e Prof. Dr. Paulo Fujioka, ambos da EESC-USP. 
Capítulo 1

Introdução

\subsection{Estrutura do trabalho}

O trabalho se organiza em dez capítulos.

O primeiro introduz o conteúdo da pesquisa e apresenta seus objetivos e método.

O segundo discorre sobre as questões da técnica e da tecnologia no campo da arquitetura e contextualiza brevemente a arquitetura no Brasil a partir dos anos de 1960, período de formação de Marcos Acayaba.

O terceiro aborda assuntos ligados à postura projetual do arquiteto, relatando aspectos relevantes em sua formação, interesses e atividades profissionais.

O quarto apresenta a residência Milan, primeiro projeto de destaque de Acayaba, realizado na década de 70, que utiliza a tecnologia do concreto armado na realização de uma cobertura curva.

O quinto capítulo expõe o projeto da Fazenda Pindorama, um conjunto de edificações cuja casa-sede e o pavilhão de recreação utilizam linguagens e recursos construtivos diferentes entre si: a casa-sede adota abóbadas feitas de blocos de concreto como cobertura, e o pavilhão, associa concreto e tijolos na constituição de suas paredes.

O sexto exibe o projeto da residência Hélio Olga, uma obra que se destaca pelo desafio de vencer a implantação em um terreno com mais de $100 \%$ de inclinação com uma estrutura pré-fabricada em madeira.

O sétimo apresenta os projetos das residências Baeta e Marcos Acayaba, investigando o sistema construtivo em ambos empregado: a estrutura em madeira pré-fabricada de base modular triangulada.

O oitavo expõe o projeto da Escola Estadual Jardim Bela Vista II, um projeto realizado para o FDE (Fundação para o Desenvolvimento da Educação), em que se explora a solução do concreto pré-moldado, criando um elemento que cumpre duas funções: a de proteção solar e a de travamento estrutural. 
Capítulo 1

Introdução

O nono apresenta o projeto da Vila Butanã, um conjunto de sobrados construídos por Acayaba e pelo engenheiro Hélio Olga de Souza Júnior para fins imobiliários, mas que foge dos padrões convencionais utilizados nesse tipo de empreendimento, adotando uma solução construtiva diferenciada, a laje nervurada de concreto e madeira.

O capítulo dez apresenta as considerações finais acerca do desenvolvimento da pesquisa. 
CAPÍTULO 2:

CONTEXTO

\subsection{Arquitetura, técnica e tecnologia}

Para falar sobre esses assuntos, faz-se necessário, mesmo que brevemente, discorrer sobre os termos técnica e tecnologia.

Esses termos têm seus significados estudados e debatidos por diversos autores, apresentando definições muitas vezes diferenciadas entre conhecimento prático e estudo científico:

[Técnica:] conjunto de regras práticas para fazer coisas determinadas, envolvendo a habilidade do executor, e transmitidas, verbalmente, por exemplo, no uso das mãos, dos instrumentos e ferramentas e das máquinas (BIROU apud GAMA, 1986, p. 30).

[Tecnologia:] estudo e conhecimento científico das operações técnicas ou da técnica. Compreende o estudo sistemático dos instrumentos, das ferramentas e das máquinas empregadas nos diversos ramos da técnica, dos gestos e dos tempos de trabalho e dos custos, dos materiais e da energia empregada (BIROU apud GAMA, 1986, p. 30).

Vargas (1994) adota definições semelhantes, definindo a técnica como "[...] uma habilidade humana de fabricar, construir e utilizar instrumentos" e relacionando o termo tecnologia ao estabelecimento da ciência moderna.

Na arquitetura, esses termos muitas vezes se misturam. Carvalho Jr. (1994) os situa como significado e função no contexto da profissão: 
Capítulo 2

Contexto

No processo projetual, o arquiteto pode utilizar tanto conhecimentos já sistematizados - tecnologia, como aqueles que têm origem na própria execução da arquitetura, normalmente denominado conhecimento construtivo - não necessariamente codificado segundo métodos científicos.

Essa pesquisa abrange questões referentes tanto à técnica quanto à tecnologia, assumindo suas distintas caracterizações. Porém, para que haja melhor fluência na leitura do texto, utilizam-se algumas vezes, como no título, os termos conhecimento técnico e/ou domínio técnico, certo modo, abrangendo também as questões científicas, isto é, de cunho tecnológico.

De qualquer forma, não é preciso bases bibliográficas para perceber que a questão da técnica sempre esteve ligada à arquitetura. Já que desde o início da humanidade, com a necessidade de se abrigar das intempéries da natureza, o homem precisou utilizar-se da técnica para construir sua moradia.

O papel do arquiteto é definido por Alberti, no século XV, relacionando arte, técnica e construção:

[arquiteto é] Aquele que, com uma razão e uma regra maravilhosa e precisa sabe, primeiramente, compreender as coisas com seu espírito e sua inteligência, e secundariamente, como organizar com precisão durante os trabalhos de construção todos os materiais que envolvem essa produção, os quais pelos movimentos de suas cargas, pela reunião e justaposição de seus corpos possam servir com eficiência e dignidade às necessidades do homem [...] (JAQUES apud SEGNINI JR., 2002, p.06).

Alguns autores, como Benévolo e Munford, indicam que, grosso modo, no período da Revolução Industrial da Europa, inicia-se uma ruptura entre a arte e a técnica no campo da arquitetura. Os arquitetos não teriam acompanhado as necessidades de desenvolvimento tecnológico exigido nas novas construções como, por exemplo, as pontes, os galpões industriais etc.

A diferenciação entre projeto e execução começa na Renascença, quando o projetista evoca para si todas as decisões, deixando aos outros apenas a realização material do edifício [...] o arquiteto reserva-se a parte artística e deixa para os outros a parte de construção e técnica. Assim nasce o dualismo de competências que ainda hoje é expresso pelas duas figuras do arquiteto e do engenheiro (BENÉVOLO, 1989, p. 29-30). 
Capítulo 2

Contexto

A profissão de arquiteto passou então a sofrer uma segmentação, oscilando entre a arte e a técnica. Fenômeno que até hoje influencia o ensino nas escolas de arquitetura e na atuação dos profissionais, ainda que os preceitos da arquitetura moderna, em função das necessidades criadas pelas guerras e da crescente industrialização, tenha ditado uma postura mais funcionalista.

Arquitetos como Le Corbusier criticam o afastamento da arquitetura das questões técnicas. Em seu livro, "Por uma Arquitetura", tece elogios à engenharia e ironiza sobre a postura puramente estética do arquiteto:

Os engenheiros são viris e saudáveis, úteis e ativos, morais e alegres. Os arquitetos são desencantados e desocupados, faladores ou lúgubres. É que em breve não terão mais nada a fazer. Não teremos mais dinheiro para construir monumentos históricos. Precisamos nos justificar. Os engenheiros pensam nisso e construirão (CORBUSIER, 1994, p.06).

No Brasil, a arquitetura moderna procurava acompanhar a crescente industrialização, buscando se adaptar às novas condições de produção que a indústria trazia (ou deveria trazer) e ao mesmo tempo dialogar com os movimentos artísticos que ocorriam no país.

O arquiteto moderno começa a ver na verdade técnica, na sinceridade de relação entre engenharia, como colaboradora do projeto, e o material uma crítica sobre a superficialidade com que o ecletismo arquitetônico tratava suas idéias a serem realizadas (ARTIGAS, 2004, p. 204).

No entanto, ainda hoje no Brasil a idéia do arquiteto como fachadista ou decorador, funções totalmente desvinculadas da técnica construtiva, tem interferido na formação e na prática de inúmeros novos profissionais e, por conseqüência, a visão da sociedade frente à profissão. A maioria das imagens demonstra um profissional inseguro quanto aos conhecimentos técnico e tecnológico (CARVALHO JR., 1994).

O arquiteto, durante a etapa projetual, é quem define as diretrizes, formas e materiais do edifício, interferindo diretamente nos índices de desperdício, impacto ambiental, economia, conforto e funcionalidade. Os erros de projeto, principalmente no que se refere às especificações de materiais e à falta de detalhamento técnico, podem resultar em construções de baixa qualidade. Além disso, como afirma o arquiteto Marcelo Accioly Fragelli, "O 
Capítulo 2

Contexto

desconhecimento da técnica pode limitar a capacidade de expressão do arquiteto, mas pior, pode fazer suas obras frágeis, vulneráveis ao envelhecimento precoce e às intempéries, deteriorável" (METODOLOGIAS..., 1982, p. 60).

Contudo, "[...] o projeto arquitetônico não é ainda arquitetura" (GREGOTTI, 1975, p. 13).

A construção é uma das mais antigas práticas humanas que surge da necessidade do homem de se abrigar das condições adversas da natureza. Representa um importante fator de desenvolvimento e progresso das civilizações e, mais do que espaço construído, é uma maneira do homem expressar suas realizações, suas conquistas e suas crenças (FABRíCIO, 1996).

Para Severiano Porto, "O arquiteto deve ter um profundo conhecimento da obra propriamente dita, pois esta sim é a razão e a atividade-fim da nossa profissão. O projeto é somente a etapa que antecede e fundamenta o seu fazer" (PORTO, 2004, p.50).

No entanto, atualmente, é freqüente nas revistas internacionais, um tipo de arquitetura em que, como diz Acayaba (2006), "[...] o arquiteto não tem a menor preocupação com construção nem com técnica, ele faz um trabalho quase que de cenografia; está entre cenografia e artes plásticas".

O arquiteto Ciro Pirondi reconhece que "nos últimos 20 anos, nos afastamos totalmente das obras, perdendo com isso não só o mercado de trabalho, mas também o controle sobre a qualidade do espaço edificado". (NAS TRILHAS..., p.80).

O domínio técnico e tecnológico, além de evitar problemas de execução e manutenção, pode fornecer subsídios para a manutenção de uma postura formal e para a realização da arquitetura como fator social, propiciando maior liberdade de criação e ampliando suas possibilidades.

[...] hoje a técnica constitui um instrumento imprescindível para pensar a arquitetura, e não exclusivamente para concretizar. [...] A compreensão mais ampla da dimensão técnica da profissão permite que a consideremos não apenas como um meio para a 
Capítulo 2

Contexto

concretização de idéias, mas, principalmente, como um poderoso e vital eixo de reflexão sobre arquitetura (TRUJILLO, 2006, p.11).

O conhecimento técnico também auxilia no diálogo entre os profissionais envolvidos no projeto e na construção, tornando-o mais direto e preciso e facilitando a interdisciplinaridade.

Atualmente a construção não depende somente do planejamento espacial, ela envolve necessariamente diversas especialidades como estrutura, fundações, hidráulica e elétrica, que influem e são influenciadas pela arquitetura, exigindo uma interatividade entre os projetos e os profissionais envolvidos no projeto e na obra.

Artigas, na primeira argüição de sua prova para titulação como professor da FAU-USP, em 1984, fala sobre a separação entre arquitetura e engenharia, e da necessidade de integração e de como ela pode ser feita, destacando a questão da interdisciplinaridade:

[...] $\circ$ arquiteto antigo não conheceu o engenheiro; não conheceu a separação entre seu trabalho criador e o homem que avalia as estruturas. [...] o arquiteto clássico era o homem falo a você como especialista em fundações - que mandava abrir um buraco e dava uma olhada com os pés para ver se dava dois quilos por centímetro quadrado ou se não dava fundação nenhuma! [...] Com a Revolução Industrial a atividade do arquiteto partiu-se; ele teve de bancar, não por causa do progresso técnico-científico, tipos de conhecimentos que até aquela época não imaginava que pudessem ser necessários. [...] Hoje o conhecimento científico nos leva, por exemplo, a andar praticando 0 que se chama interdisciplinaridade, uma convivência com o que é a suplantação de um grande período histórico, em que $\mathrm{o}$ arquiteto tem onde assumir a responsabilidade artística e exprimir o pensamento de uma determinada época, por intermédio de sua visão artística, mas essa visão era também a própria construção que ele realizava (ARTIGAS, 2004, p. 204-205).

Acayaba, em entrevista, admite que "Às vezes, é uma conversa com o engenheiro, com o construtor, que define até essa questão da técnica a ser usada" (ACAYABA, 2006).

Nesse trabalho, procura-se explorar soluções em que se fundem intenções de arte e técnica, associando em uma só resposta os ideais de engenharia e de 


\section{Capítulo 2}

Contexto

arquitetura. Os recursos construtivos utilizados nos projetos são investigados como solução técnica, mas para tanto:

Uma solução técnica não pode ser cabalmente entendida sem que se conheça o contexto que motivou seu desenvolvimento; por esse motivo, a compreensão do por que uma solução efetivamente soluciona algo, deveria anteceder à sua pura descrição (TRUJILLO, 2006, p.10).

O item a seguir discorre brevemente sobre o contexto da arquitetura brasileira a partir da formação do arquiteto Marcos Acayaba para, no próximo capítulo, demonstrar nuances de sua postura profissional e, em seguida, introduzir alguns de seus projetos. 
Capítulo 2

Contexto

\subsection{Breve panorama da arquitetura no Brasil pós 60}

A arquitetura brasileira a partir das décadas de 1940 e 1950 passou por um momento de grande prestígio e reconhecimento internacional, tendo como auge a construção e inauguração de Brasília, no início da década de 1960.

Em 1964, com o golpe militar, houve uma reversão no quadro político e econômico do país, culminando no fim da conciliação política-ideológica consignada pela bandeira do nacional-desenvolvimentismo, que, grosso modo, inaugurou um período de repressão às manifestações políticas e intelectuais (BASTOS, 2003). Nesse período, o Brasil ainda vivia uma época de grande anseio pelo desenvolvimento.

A produção intelectual no meio acadêmico, mesmo com a repressão do regime militar, teve uma sobrevida e, na arquitetura, as atividades políticas subsistiam em forma de posturas projetuais. Isso se fez presente na atuação de arquitetos como Vilanova Artigas, que buscava desenvolver uma arquitetura que, de certa forma, denunciasse o modelo político, contra o qual se posicionava (BUZZAR, 1996). Essa arquitetura buscava manter uma postura preocupada com questões sociais e políticas, tendo como mote a industrialização da construção no Brasil.

Foi nessa época de grandes rupturas, agitações sociais e direcionamentos políticos que Marcos Azevedo Acayaba (nascido em 1944) ingressou na FAUUSP em 1964, formando-se arquiteto em 1969. Tendo conhecido o auge da agitação política-cultural e o posterior endurecimento do regime, com a cassação de diversos professores. Dentre os quais, Sérgio Ferro e Rodrigo Lefèvre que, em oposição à postura de manter a atividade dos arquitetos restrita ao campo da produção arquitetônica, iniciaram uma forte crítica, como consta no trecho do texto Arquitetura Nova, escrito por Sérgio Ferro em 1967: 


\section{Capítulo 2}

\section{Contexto}

formas das direções. Alienados de sua função real por um sistema caduco, reagem dentro da faixa que o sistema thes atribui, aprofundando, com isto, a ruptura entre sua obra e a situação objetiva a ser combatida. Para enfrentar as forças negativas que os diluem, aceitam a fragmentação da particularidade, o que é outra forma de diluição. Adensando seus projetos, revestindo-os de malabarismos expressivos para agredir, afastam-se mais e mais do objeto da agressão: complexos demais, já não são ouvidos (FERRO, 2006, p.50-51).

Suas aspirações e militâncias políticas, que extrapolavam o debate arquitetônico, acabaram ocasionando em sua deportação, exilando-se na França, onde se manteve ativo profissionalmente como professor da Escola de Arquitetura de Grenoble e onde vive até hoje.

Somente com a publicação de seu livro "O Canteiro e o Desenho" 1, em 1979, suas idéias passaram a ser mais difundidas no país, fazendo crítica à exploração das relações de produção e concepção da arquitetura posta em prática pelo modernismo brasileiro, principalmente na construção de Brasília.

Ferro nesse livro levanta a idéia de que a arquitetura moderna, até então praticada no Brasil e tão amplamente difundida com a fundação de Brasília, alienava o trabalhador da construção civil, pois propunha um grau de industrialização e desenvolvimento técnico que afastava a mão de obra do processo de produção e criação do conjunto da obra.

Se para Artigas a elaboração de um projeto cultural autônomo passava pela superação do subdesenvolvimento com a adoção de um projeto de modernização técnica baseado nos países ricos, para a Arquitetura Nova tal superação dependia da elaboração de um modelo tecnológico baseado no emprego intensivo de mão de obra e de menos investimentos em mecanização da produção, ou seja, um processo a ser realizado com os recursos possíveis e com os limites existentes no contexto efetivo do país (KOURY, 2003, p.56).

Em entrevista concedida à Revista Caramelo, Acayaba fala sobre essa polaridade conformada na FAU:

[...] em 67 teve o que se chamou de "racha do partido". Duas posições se separaram, inconciliáveis, e membros dos dois lados existiam também dentro da escola, passando a ter posições

\footnotetext{
1 O texto foi primeiramente publicado em 1976, dividido em duas edições (2 e 3) da revista Almanaque, sob os títulos: "A forma da arquitetura e o desenho da mercadoria" e "O desenho".
} 
opostas. Dando nome aos bois era o Artigas de um lado e o Sérgio Ferro do outro. O que eram essas posições? Vocês sabem, mas é o seguinte: o Sérgio Ferro representava o grupo que partiu naquele momento para a luta armada. Antes de mudar 0 regime e a sociedade, não interessava fazer arquitetura. Fazer pra quê? Fazer arquitetura seria compactuar com o regime. Enquanto o outro lado viu a coisa mais a médio e a longo prazo, dizendo que não, que nós tínhamos que resguardar certas conquistas e continuar trabalhando. Foi uma loucura total, porque o pessoal partiu pra luta armada... uma luta perdida de antemão. Com isso a gente perdeu muita gente importante, foi uma tristeza, e acabou (ACAYABA, 1991, p. 10).

No entanto, o regime militar, com suas aspirações desenvolvimentistas, inicia uma fase de expansão, ocasionando na realização de grandes investimentos em áreas de infra-estrutura: centros cívicos e administrativos, hospitais, estações, escolas (campi universitários), conjuntos habitacionais, centrais de energia, aeroportos, rodoviárias, centrais de telefonia entre outros, fazendo do Estado o principal cliente dos arquitetos. Era o chamado "milagre econômico".

[...] enquanto as artes de modo geral foram silenciadas, a censura para nós veio com a concentração de riquezas [...] os órgãos do governo concentravam as obras de infra-estrutura, as chamadas obras faraônicas, no período Médici. Estava aberto um certo espaço para o exagero, impondo o esquecimento de toda evolução que caracterizava a arquitetura brasileira, com os programas adequados à realidade nacional e ao contexto político-social do momento (PRANCHETA, 1986, p. 57).

A intensa demanda arquitetônica ocasionada pelo grande número de obras públicas criou certa euforia por parte de muitos arquitetos, que geraram, em muitos casos, uma produção acrítica, que adotava aleatoriamente elementos "símbolos de uma arquitetura nacional", como protetores solares (brises), grandes vãos, rampas, concreto aparente etc. Existia muita produção e pouco debate arquitetônico.

Não importava o programa de uso: da casa ao viaduto, da agência bancária ao forno crematório, da escola, à torre de garagem, do sofá ao edifício administrativo - era a moda (ou ditadura) das grandes estruturas de concreto, do concreto aparente, dos pilares esculturais, das estruturas protendidas, do exibicionismo estrutural, a competição por vãos livres maiores, dos panos de vidro - imitações esvaziadas dos conteúdos elaborados por mestres como Niemeyer, Vilanova Artigas e seguidores consistentes (SEGAWA, 1999, p. 191). 
Capítulo 2

Contexto

Nos anos de 1980, com o fim do regime militar, inicia-se uma grave crise econômica. Junto com a redemocratização, há a retomada do debate arquitetônico, que havia sido suspenso durante o período do governo militar. Inicia-se nesse momento uma revisão crítica da arquitetura moderna e de toda a produção realizada nas últimas décadas.

As mitológicas obras da arquitetura dos anos de 1950-1960, por falta de manutenção e por obsolescência, transformaram-se em ruínas da modernidade; Brasília, cidade elaborada no período democrático, amadurecida durante o regime militar, confundese com o caráter autoritário do período; as realizações dos anos de 1970, pela suntuosidade e pelo monumentalismo, transformando-se no símbolo da burocracia estatal e do desperdício (SEGAWA, 1999, p. 197).

Em 1990, a Revista Projeto publicou um debate sobre a produção dos anos 80 , em que o arquiteto Antonio Carlos Sant'Anna Jr. dá um breve panorama entre o período de sua formação e o que se sucede:

Eu me formei em 1974, pela FAU/USP. No meu tempo de escola, a questão do prazer em arquitetura estava absolutamente interditada. Foram exatamente os anos do governo Médici e essa interdição foi colocada pelos próprios professores e estudantes de arquitetura: necessário substituir o lápis por instrumentos mais contundentes. Acredito que essa questão não seja só paulistana! No início dos anos 80 , o processo de abertura política que começa a se firmar no Brasil dá à sociedade civil oportunidade de se manifestar de maneira mais aberta, mais franca. A arquitetura começa a encontrar seu espaço, às vezes até de maneira excessiva (EM DEBATE..., 1990, p. 144)

A produção moderna ainda exercia forte influência no debate e na prática arquitetônica. Por outro lado, nesse momento, novos temas foram introduzidos na arquitetura, trazendo questões como o maior diálogo do edifício com o sítio onde se insere (urbano ou rural) e com as realidades locais, o reconhecimento da história como referência projetual, o questionamento do mito do autor em função de uma atividade projetual coletiva (arquitetos/ arquitetos, arquitetos/ usuários), entre outros.

Conceitos como o respeito pelo contexto, pela tradição e pelo o meio físico em que se insere um edifício também surgem como uma crítica à política de "tabula rasa" modernista (BASTOS, 2003). 
Capítulo 2

Contexto

A partir da crise energética iniciada nos anos de 1970, quando se passou a ter consciência de que os recursos eram finitos, surgiram discussões relacionadas ao meio ambiente, as quais passaram a influenciar a produção arquitetônica das décadas seguintes, seguindo em debate até hoje.

O processo de conscientização ecológica fez com que os materiais tradicionais tivessem seu uso re-valorizado. Obras realizadas ainda nas décadas anteriores passaram a ganhar destaque, como é o caso da experiência de Lúcio Costa, com o projeto do Parque Hotel São Clemente (BASTOS, 2003).

Com a revalorização, no anos de 1980, das técnicas tradicionais, o Park Hotel São Clemente, em Nova Friburgo, tornou-se a obra emblemática de Lúcio Costa, na busca de síntese entre a tradição local e o espírito moderno (BASTOS, 2003, p. 141).

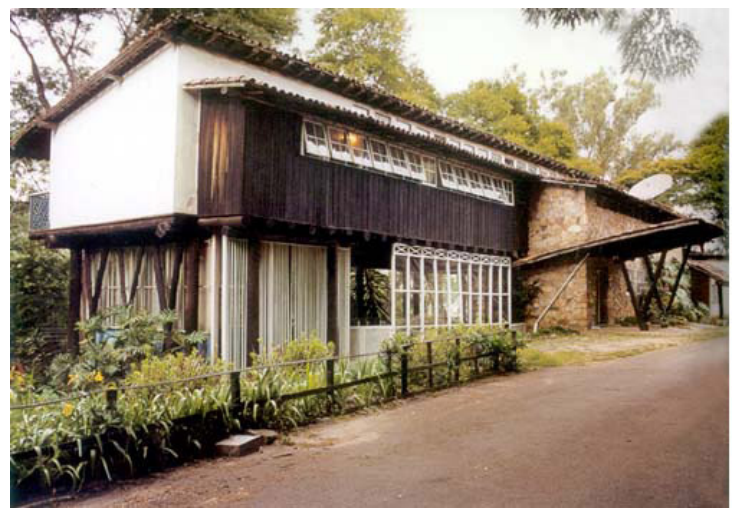

Fig. 2.1: Park Hotel São Clemente, Nova Friburgo, 1944-1945. Lúcio Costa.

(fonte: OLIVEIRA, 1992)

A produção arquitetônica brasileira passou então a assimilar novamente materiais típicos da arquitetura tradicional, como é o caso da madeira e do tijolo.

Um exemplo desse fenômeno é um projeto de 1982, o da residência dos Padres Claretianos em Batatais, SP, de Affonso Risi Jr. e José Mário Nogueira de Carvalho Jr., uma obra que propunha a utilização de um material tradicional, - tijolo, mas associado a novas técnicas construtivas, priorizando a humanização do canteiro e cultivando a criatividade da mão de obra.

Também se destaca nesse quadro o projeto do Centro de Proteção Ambiental de Balbina, em Manaus, AM, de Severiano Mário Porto, iniciado em 1983, que 
Capítulo 2

Contexto

utiliza a madeira como estrutura e cobertura, e paredes de alvenaria de tijolos como vedação.

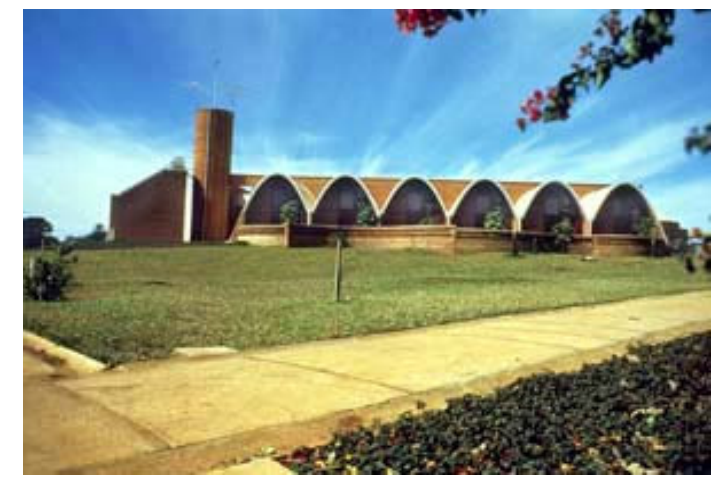

Fig. 2.2: Residência dos Padres Claretianos de Batatais. Affonso Risi Jr. e José Mário Nogueira Jr. 1982-1984. (fonte: LEMOS, 2005)

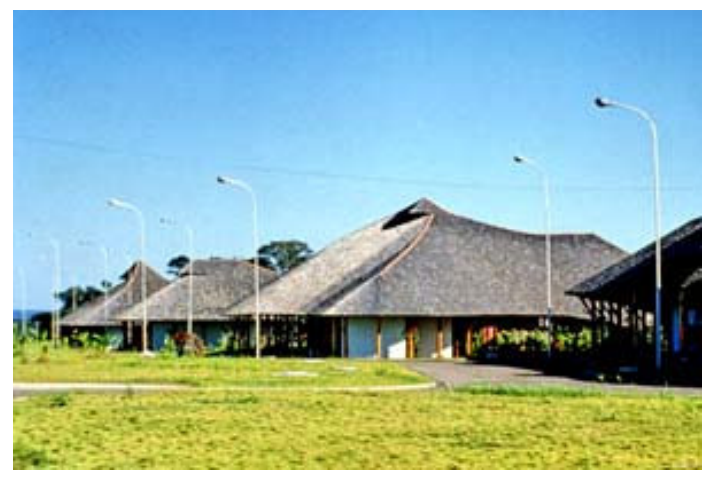

Fig. 2.3: Centro de Proteção Ambiental da Usina Hidrelétrica de Balbina. Severiano Porto. 1983-1988. (fonte: LEMOS, 2005) 
Capítulo 3

Marcos Acayaba

\section{CAPÍTULO 3:}

MARCOS ACAYABA

Discípulo do mestre Vilanova Artigas, Acayaba trouxe para sua prática profissional um forte interesse pelas questões técnicas, numa constante investigação arquitetônica.

Transitando por entre os mais variados tipos de materiais e técnicas construtivas, Acayaba experimenta as potencialidades de cada material na formulação do espaço arquitetônico e nas contribuições às intenções formais de cada projeto.

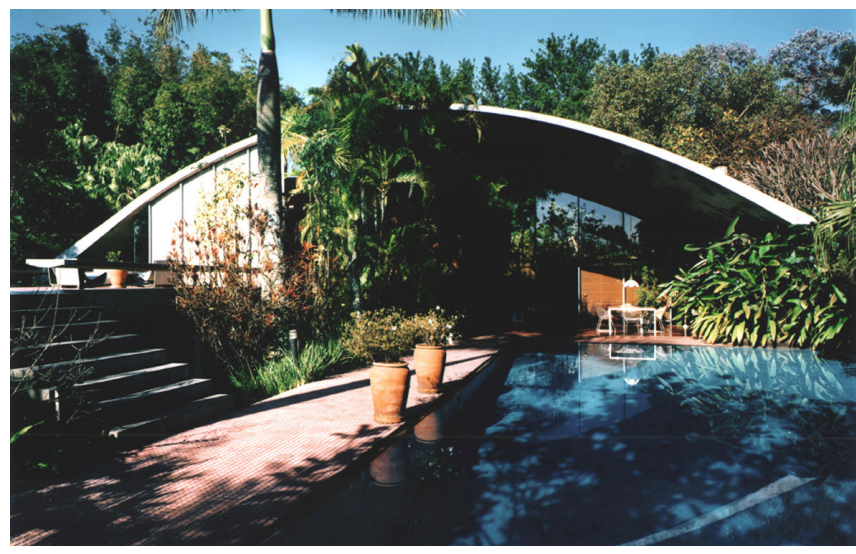

Fig. 3.1: Residência Milan 1972-1975: Casca em concreto armado. (fonte: arquivo pessoal Marcos Acayaba)

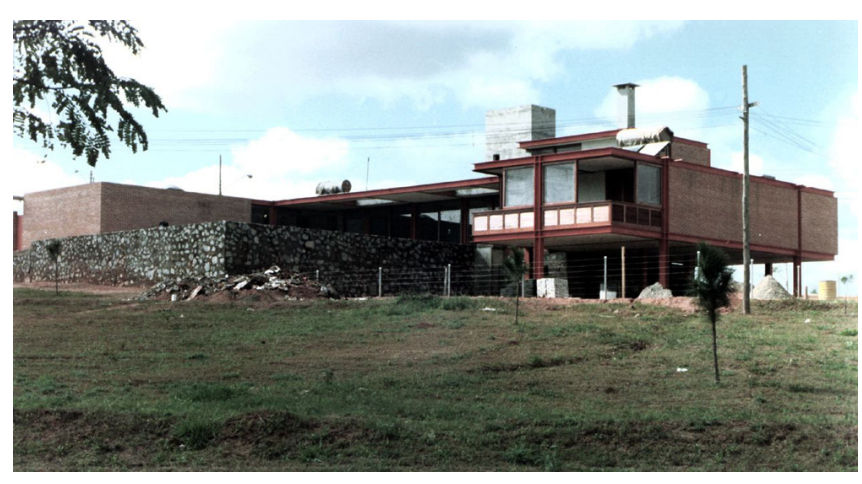

Fig. 3.2: Residência em Alphaville 19811982: Estrutura em aço com elementos de vedação em pedra e alvenaria de tijolos. (fonte: MARCOS ACAYABA ARQUITETOS, 2007) 
Capítulo 3

Marcos Acayaba

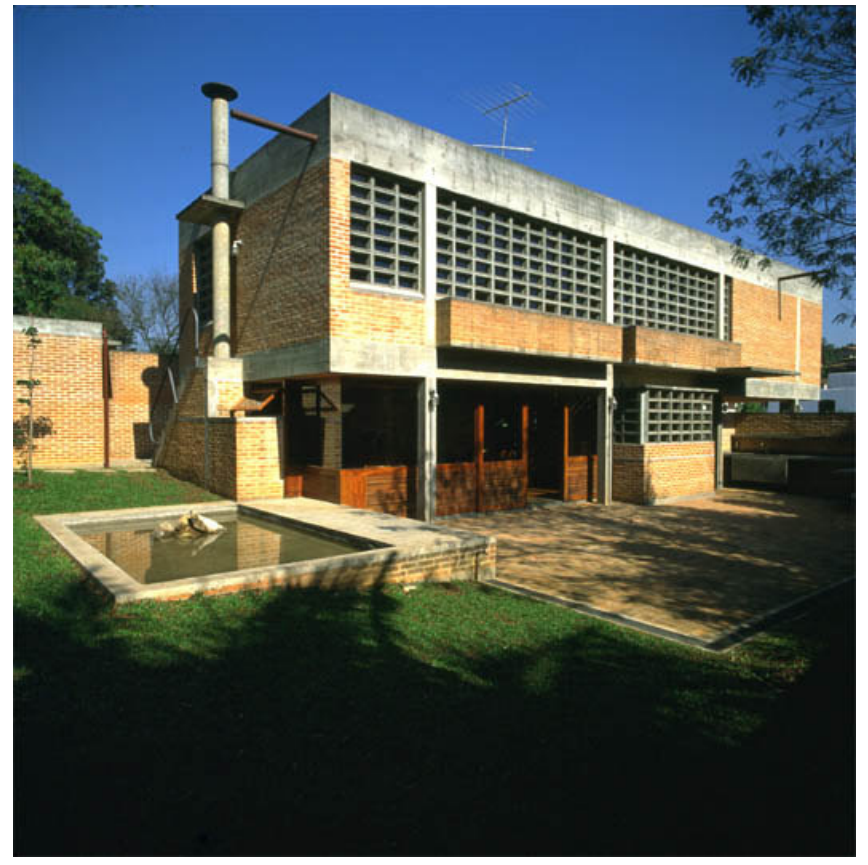

Fig. 3.3: Residência Hugo Kovadloff 1986-1987. Estrutura em concreto armado com vedação em alvenaria de tijolos. (fonte: arquivo pessoal Marcos Acayaba)

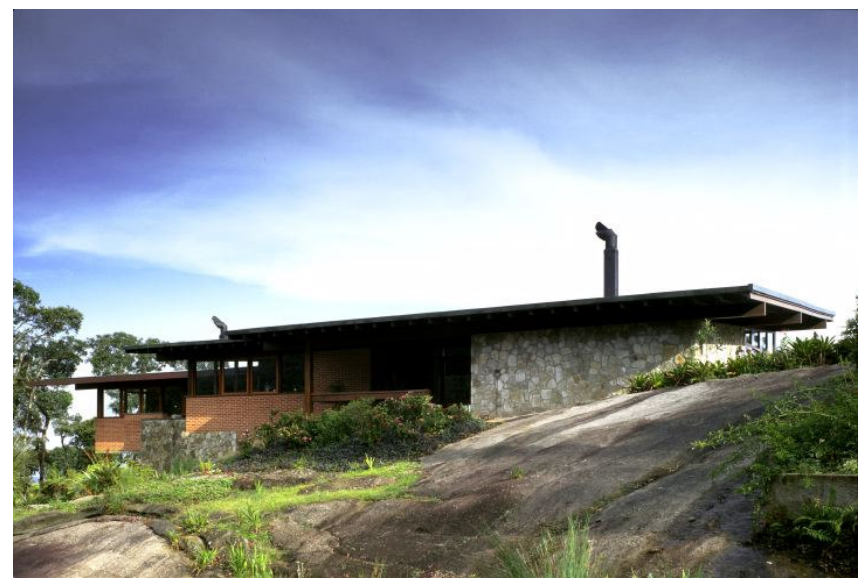

Fig. 3.4: Residência em Monte Verde 1994-2000. Estrutura em madeira com vedação em tijolos e pedras. (fonte: MARCOS ACAYABA ARQUITETOS, 2007)

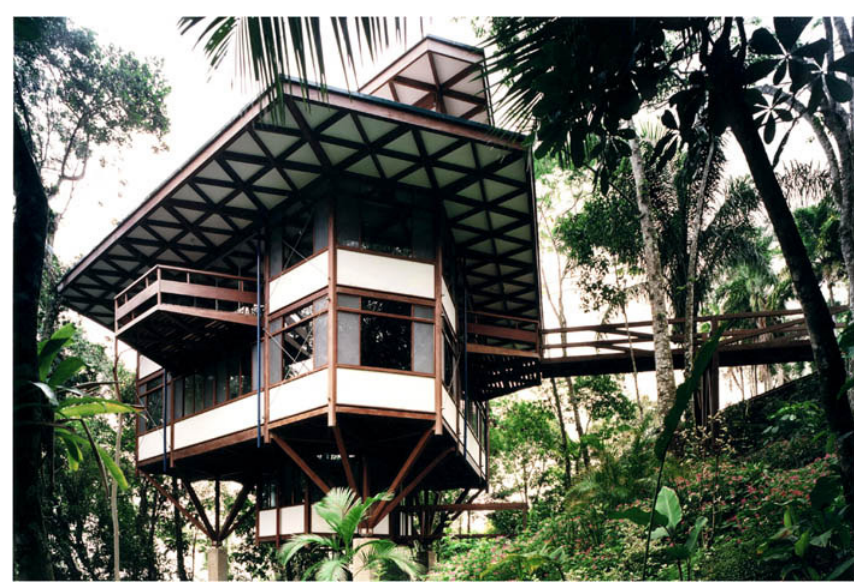

Fig. 3.5: Residência Marcos Acayaba 1997. Estrutura préfabricada em madeira. (fonte: arquivo pessoal Marcos Acayaba) 
Capítulo 3

Marcos Acayaba

\subsection{Formação, referências e parcerias}

Acayaba ingressou na FAU USP em 1964. Não havia muitos anos que a Faculdade de Arquitetura havia se desvinculado da Escola Politécnica. Grande parte de seus professores vinha da Politécnica como, por exemplo, seu grande mestre, formado engenheiro-arquiteto, Vilanova Artigas.

Havia na escola uma grande ênfase em questões técnicas. Tínhamos muitos professores engenheiros e, mesmo entre os arquitetos vários tinham formação politécnica. Nosso professor mais importante, João Vilanova Artigas, era engenheiroarquiteto formado pela Escola Politécnica (ACAYABA, 2004, p. 21).

Naquele momento, a busca por uma tecnologia construtiva que sustentasse os conceitos de industrialização acarretou na expansão do uso do concreto armado, que através de suas diversas formas permitiu a criação de uma nova linguagem e de novas relações espaciais.

A variedade de possibilidades plásticas que o material propiciava fez com que se tornasse uma solução corrente entre os arquitetos. Ainda mais depois da construção de Brasília, que estabeleceu uma nova linguagem na arquitetura nacional.

Segundo Acayaba (2004), logo no início de sua carreira, quando teve a oportunidade de realizar um projeto com maior liberdade, o da residência Milan, acabou optando por realizar uma casca curva em concreto armado, adotando uma postura mais formalista, numa referência à arquitetura de Niemeyer, a que mais gostava, desde a infância.

Nesse mesmo período, outros arquitetos também realizavam experiências com construção em abóbada, como é o caso de Sérgio Ferro que, por outro lado, adotava uma postura mais ligada às questões sociais, preocupada com a qualificação da mão de obra e a utilização de materiais tradicionais associados a técnicas construtivas diferenciadas. 


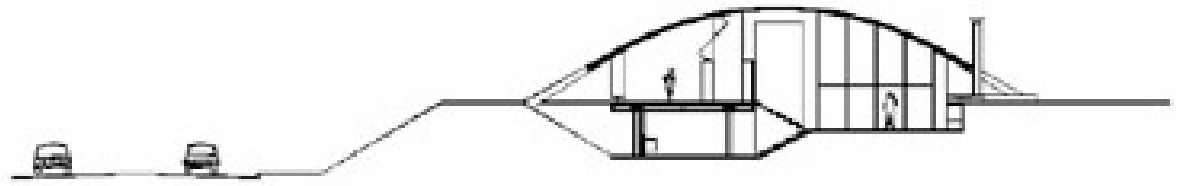

Fig. 3.6: Residência Milan, de Marcos Acayaba. (fonte: arquivo pessoal Marcos Acayaba)

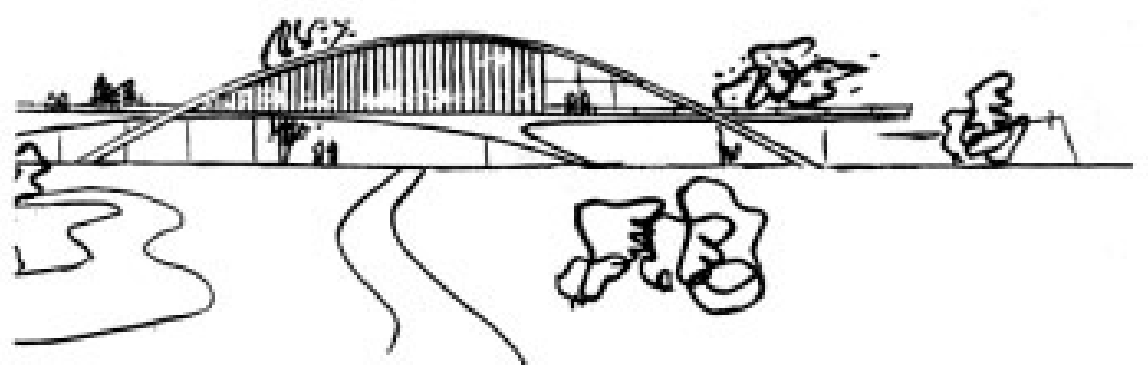

Fig. 3.7: Clube Diamantina, de Oscar Niemeyer. (fonte: arquivo pessoal Marcos Acayaba)

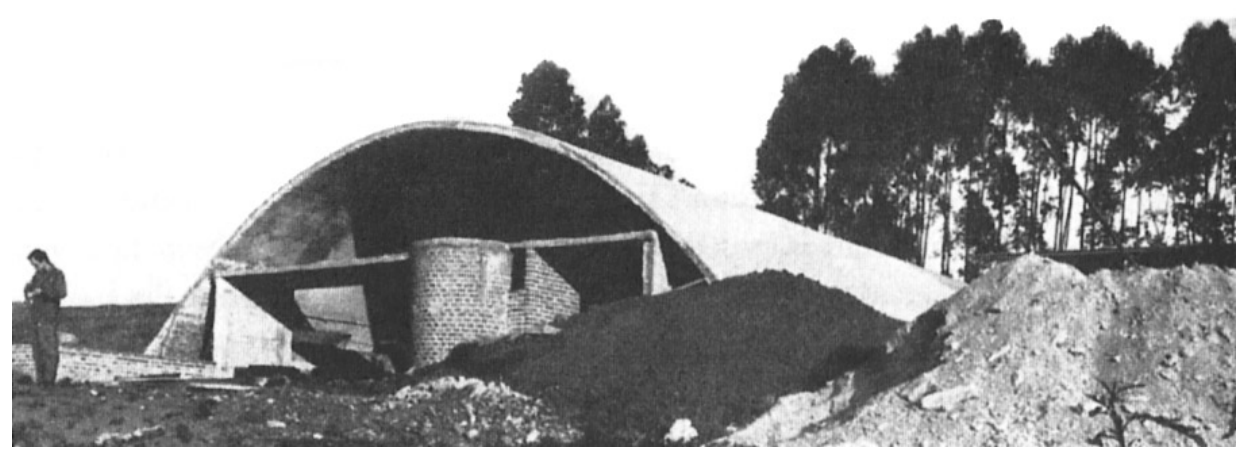

Fig. 3.8: Residência em Cotia, de Sérgio Ferro. (fonte: FERRO, 2006)

Nos anos de 1980, as preocupações ambientais trouxeram à tona arquiteturas marcadas pelo uso de materiais tradicionais locais, como a madeira e os tijolos, por exemplo.

Nesse período Acayaba fez o projeto da Residência Hugo Kovadloff, que já manteve uma postura bem mais modesta em termos construtivos, adotando estrutura em concreto armado e vedação em tijolo aparente, fazendo 


\section{Capítulo 3}

Marcos Acayaba

referências às Maisons La Roche e Jaoul, de Le Corbusier, e às Usonian Automatic Houses, de Frank Lloyd Wright.

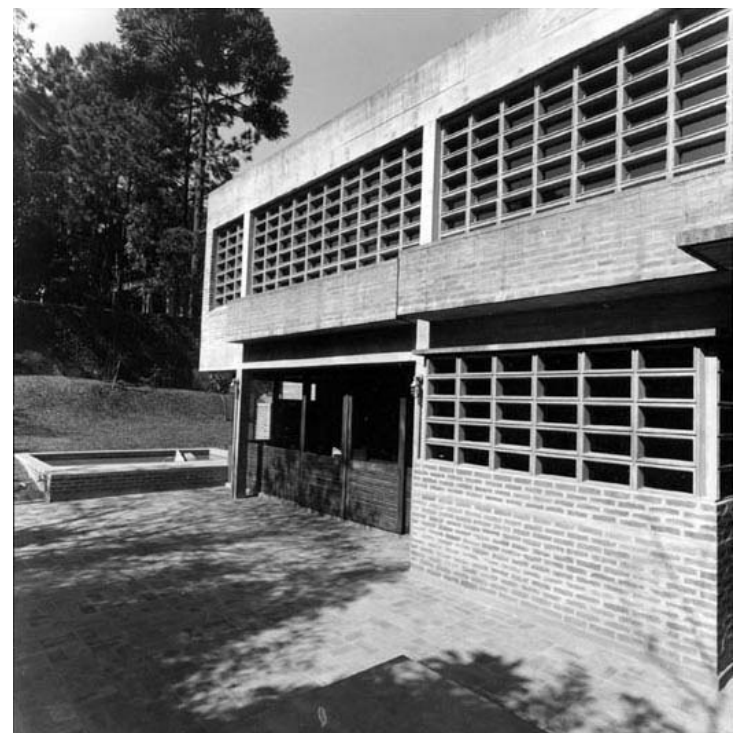

Fig. 3.9: Residência Hugo Kovadloff. (fonte: arquivo pessoal Marcos Acayaba)

No fim dos anos de 1980 e início dos anos de 1990, Acayaba passou a trabalhar também com madeira. A primeira obra de destaque nesse segmento foi a residência Hélio Olga, sobre a qual o arquiteto menciona referências da arquitetura japonesa:

Para aprender a 'falar uma nova língua', a da estrutura padronizada, aproveitei para realizar o antigo desejo de fazer uma casa japonesa. Afinal, desde o século XII, se não antes, os japoneses fazem uso de estruturas em madeira moduladas padronizadas e produzidas em série (ACAYABA, 2004, p. 75).

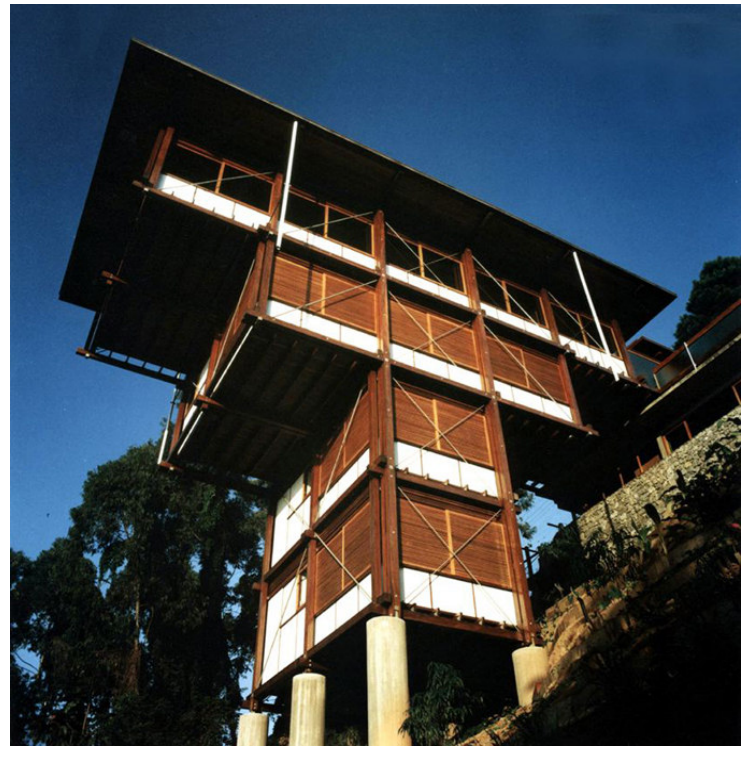

Fig. 3.10: Residência Hélio Olga. (fonte: arquivo pessoal Marcos Acayaba) 


\section{Capítulo 3}

Marcos Acayaba

A arquitetura japonesa também foi referência constante nos trabalhos de Frank Lloyd Wright, arquiteto admirado e referenciado por Acayaba em diversas obras como, por exemplo, no projeto da Residência Calabi, de19891991:

Ainda que essa casa tenha referências na arquitetura tradicional japonesa, a vejo mais como resultado do meu interesse crescente na arquitetura de Frank Lloyd Wright (ACAYABA, 2003, v.1, p.81).
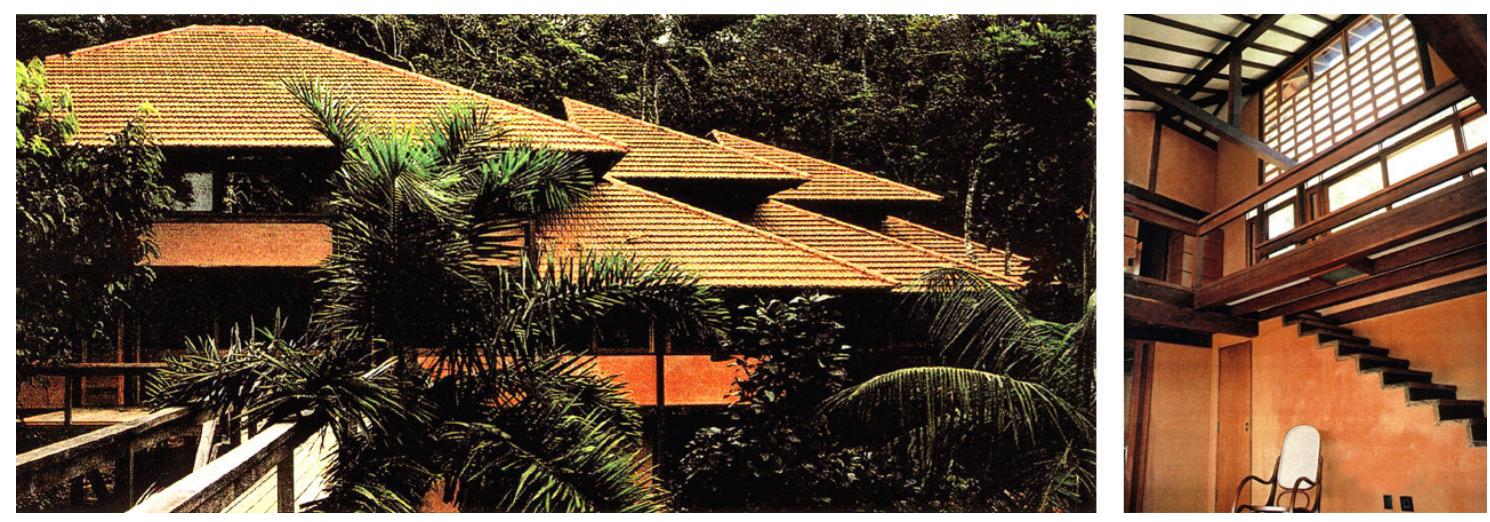

Fig. 3.11: Residência Calabi 1989-1991, Guarujá-SP. (fonte: MARCOS ACAYABA ARQUITETOS, 2007)

O pesquisador e professor Paulo Fujioka, em sua tese de doutorado, o explora as inter-relações entre a obra de Wright e de Acayaba, suas referências à arquitetura oriental e suas posturas organicistas. Analisa os projetos em madeira de Acayaba executados no sistema de triangulação da estrutura.

Com a arquitetura das casas-árvore, Acayaba atinge justamente os ideais wrightianos da destruição da caixa, de dissolução dos limites entre interior e exterior, além do rompimento do esquema pilar/viga/laje [...] todos os elementos da estrutura não agem somente como esqueleto, mas servem wrightianamente aos objetivos do programa la noção organicista das partes em relação ao todo) (FUJIOKA, 2003, p. 255). 
Capítulo 3

Marcos Acayaba
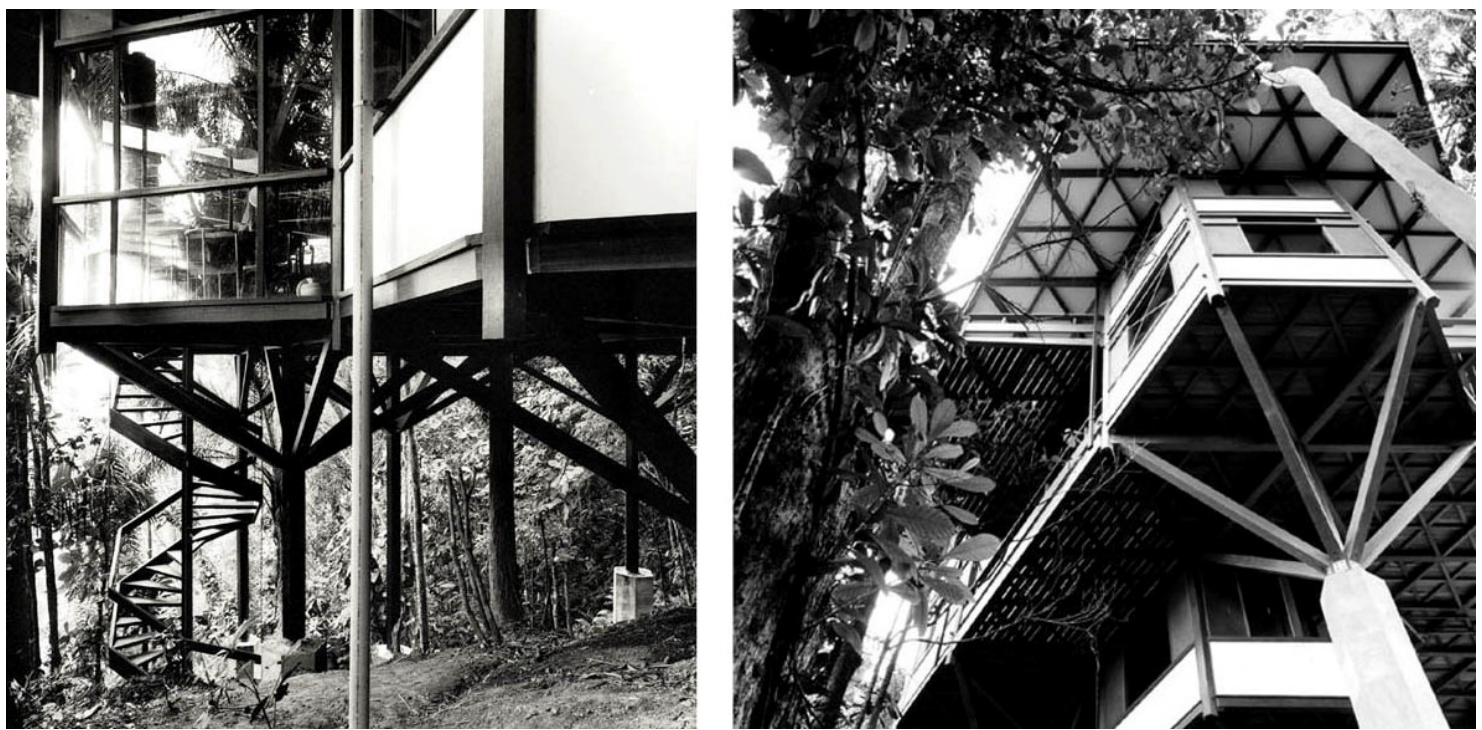

Fig. 3.12: "Casas-árvore". Residência Baeta 1993-1994 e Residência Marcos Acayba 1997. (fonte: arquivo pessoal Marcos Acayaba)

Como demonstra Fujioka, há uma estreita relação entre as posturas de Wright, Artigas e Acayaba, num processo em que a preocupação com a solução construtiva se vincula diretamente à estruturação rigorosa do programa, tendo como resultado, a linguagem plástica do edifício, e não o contrário, como se vê na postura de muitos arquitetos.

Em Artigas vemos também, além da preocupação genérica com o partido e a expressão espacial rigorosa do programa, a preocupação com a solução construtiva. Temos aí a presença do método wrightiano, tão difícil de ser copiado ou mesmo entendido, sobrepondo-se ao modelo corbusiano (FUJIOKA, 2003, p.248).

Acayaba também fala dessa relação:

Wright é engraçado, como ele nunca teve estilo, ele fez de tudo, usou todo tipo de tecnologia, de material, de linguagem. Wright não é um arquiteto de fazer modelos para serem copiados. Ele tem um método [...] Têm raros exemplos de wrightianos bem sucedidos. O Artigas é um ótimo exemplo, porque tem aquela questão do método... (ACAYABA, 1991, p.10, grifo nosso).

Artigas, como professor, sempre foi muito aberto. Estimulava, provocava a criatividade dos alunos. Também não gostava que o copiassem. "Esse cara não entendeu nada...", era como reagia, diante de certas obras, com elementos do seu repertório, mal usados, ou mal colocados no discurso arquitetônico. Ao invés de um estilo, tanto como professor, quanto através de seus projetos, sempre didáticos, Artigas 


\section{Capítulo 3}

Marcos Acayaba

transmitia um método; a partir duma interseção, uma organização semântica do programa, equacionada numa espacialidade própria, através dum desenho rigoroso mas também significativo da estrutura, da construção. Acho que tem sido meu próprio método de trabalho. Entretanto, talvez por isso mesmo, meus projetos muito raramente acabam parecidos com os do Professor Artigas, formalmente (ACAYABA, 2003, p.236, grifo nosso).

Nessas citações, Acayaba deixa claro que, como discípulo, sempre adotou os ideais que seu mestre Artigas pregava.

A idéia de que o arquiteto deve adotar uma postura relacionada aos fatores sociais, técnicos e econômicos atribuídos por cada situação, e não simplesmente assimilar e aplicar um modelo, também se encontra presente no discurso de Walter Gropius:

Quero que o jovem arquiteto seja capaz de encontrar seu próprio caminho, quaisquer que sejam as circunstâncias, que ele crie independentemente formas autênticas, a partir de condições técnicas, econômicas e sociais a ele dadas, em vez de impor uma fórmula aprendida a um ambiente que talvez exija uma solução completamente dispersa. Não pretendo ensinar um dogma acabado, mas, sim, uma atitude perante os problemas de nossa geração, uma atitude despreconcebida, original e maleável (GROPIUS, 1974, p. 25-26).

No geral, o trabalho de Acayaba reflete uma postura preocupada com os métodos e os processos de projeto'. Isso acaba resultando na adoção de diversas tecnologias construtivas, elegidas em função das particularidades de cada projeto, como o relevo, o clima e o programa. Nos trabalhos em madeira citados por Fujioka, ressalta-se também a parceria entre Marcos Acayaba e o engenheiro Hélio Olga de Souza Júnior que, quando perguntado sobre o conflito existente entre engenheiros e arquitetos, afirma:

Esse conflito, na maioria das vezes, existe entre maus engenheiros e maus arquitetos. Cansei de participar de reuniões nas quais o arquiteto sugere algo que faz sentido, mas o engenheiro preguiçoso, que não quer pensar, diz que não é possível e o arquiteto, sem conhecimento técnico, conforma-se (SOUZA JR., 2002, p. 07).

\footnotetext{
1 Em alguns momentos, no entanto, isso parece ocorrer simplesmente pela influência da produção arquitetônica da época, numa ânsia de experimentar as novas técnicas, formas e soluções que iam surgindo, como é o caso da residência Milan. Essas questões serão mais discutidas ao longo da pesquisa.
} 
Capítulo 3

Marcos Acayaba

Hélio, assim como Acayaba, vem cultivando ao longo de sua atividade profissional um profundo interesse pela construção:

Quando eu era criança, meu pai e meu tio tinham uma construtora, e eu convivia muito com obras. Sou mais construtor do que engenheiro. Interesso-me mais por "como fazer" do que pelo estudo de teoria, como faz um engenheiro calculista no sentido clássico da palavra (SOUZA JR., 2002, p. 06).

Procuro, a partir da análise conjunta de todas as condicionantes, deduzir qual a melhor estratégia para a realização da obra. Assumo, então, a estratégia de obra, onde o processo de produção é fundamental, como uma referência, como uma bússola, para orientar a concepção e desenvolvimento do projeto ${ }^{2}$ (ACAYABA, 2004, v.1, p.22).

O interesse pelas obras e pelas técnicas construtivas acabou aproximado os dois profissionais. Em 2002, após trabalharem juntos em cerca de quinze projetos em madeira, os quais renderam inúmeras publicações e prêmios pelo aprimoramento espacial e por suas inovações construtivas, Acayaba e Hélio se associaram na realização de um empreendimento imobiliário, a Vila Butantã. Um conjunto de casas na cidade de São Paulo que foge do padrão imobiliário atual. Apresenta soluções diferenciadas tanto técnica quanto espacialmente, tendo sido criada e patenteada uma nova solução de laje mista de madeira e concreto, como mostra o capítulo 9.

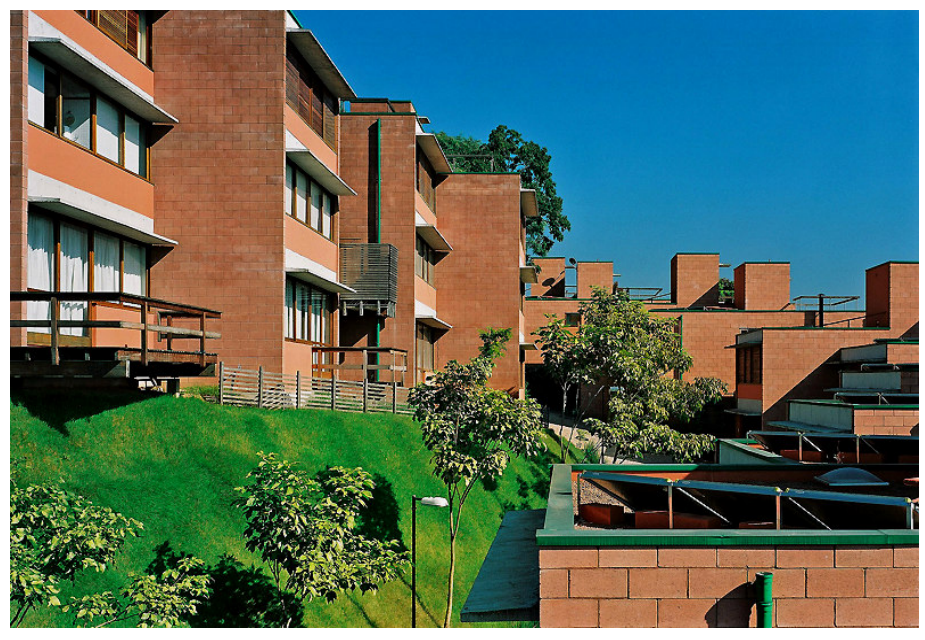

Fig. 3.13: Vila Butantã 2002. (fonte: MARCOS ACAYABA ARQUITETOS, 2007)

\footnotetext{
2 Essa citação faz parte de um texto recentemente escrito, é uma postura de trabalho atual (ver anexo A), resultado de uma experiência, como o próprio Acayaba afirma, de mais de trinta anos de profissão, como projetista e professor. Em seus projetos as nuances desse discurso são mais ou menos presentes ao longo de sua carreira.
} 
Capítulo 3

Marcos Acayaba

\subsection{Formas de estudo e representação de projeto}

O domínio das técnicas da construção propicia ao arquiteto maior liberdade no desenvolvimento do projeto na medida em que oferece subsídios para a utilização de recursos variados em termos de materiais e soluções construtivas. Porém, outras formas de domínio técnico também podem influenciar na elaboração de um projeto arquitetônico e na prática profissional de um arquiteto, como o domínio das técnicas de estudo e de representação de projeto, tais como o desenho, a fotografia e as maquetes físicas e eletrônicas. Acayaba revela que, durante sua graduação, trabalhou como fotógrafo. Também chegou a fazer perspectivas para arquitetos como Ruy Ohtake e alguns professores da FAU-USP (informação verbal) ${ }^{3}$.
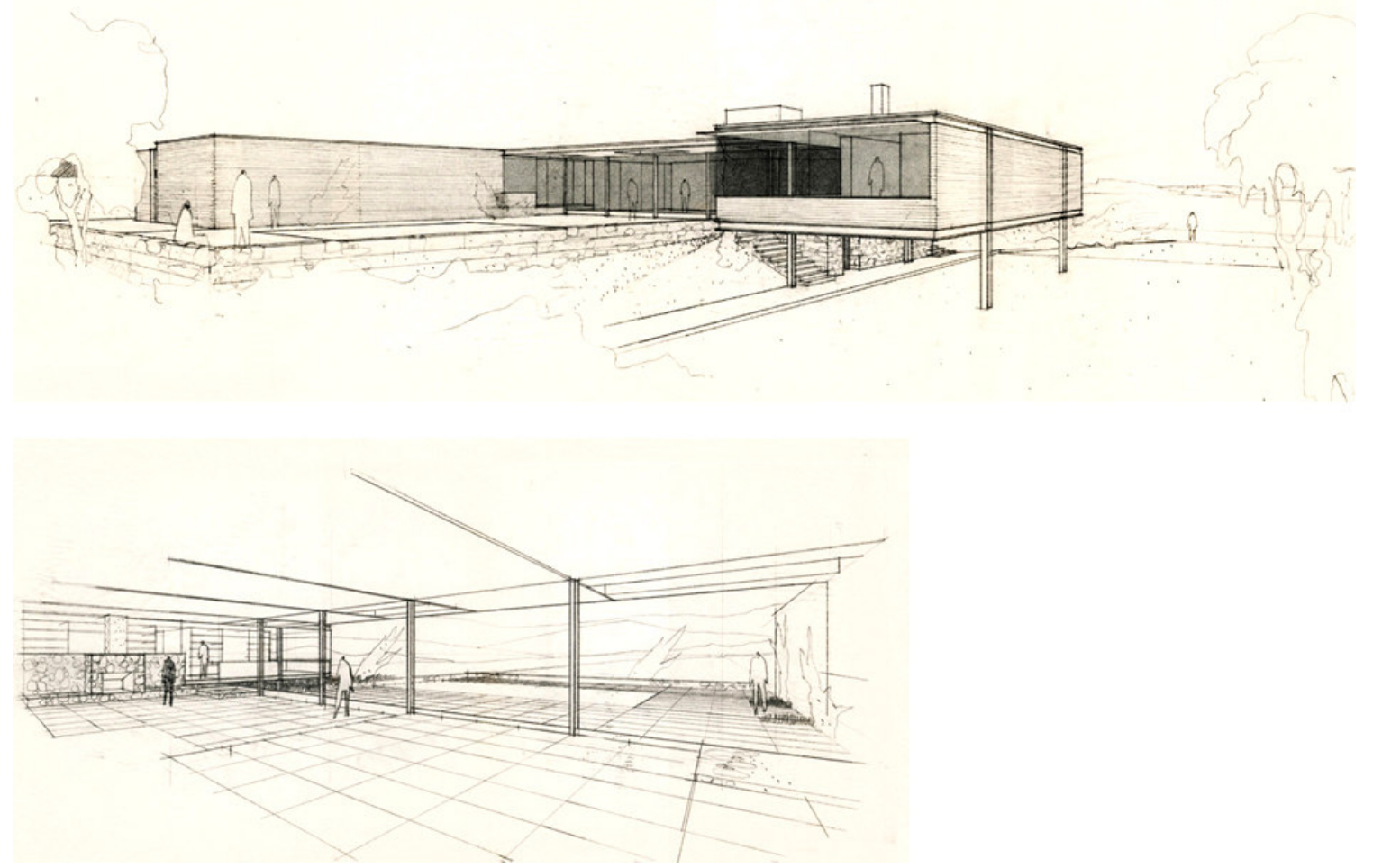

Fig. 3.14: Perspectivas feitas à mão (grafite) por Acayaba para residência em Alphaville 19811982. (fonte: MARCOS ACAYABA ARQUITETOS, 2007)

\footnotetext{
3 Informação dada por Acayaba em visita a sua residência no Guarujá.
} 
Capítulo 3

Marcos Acayaba

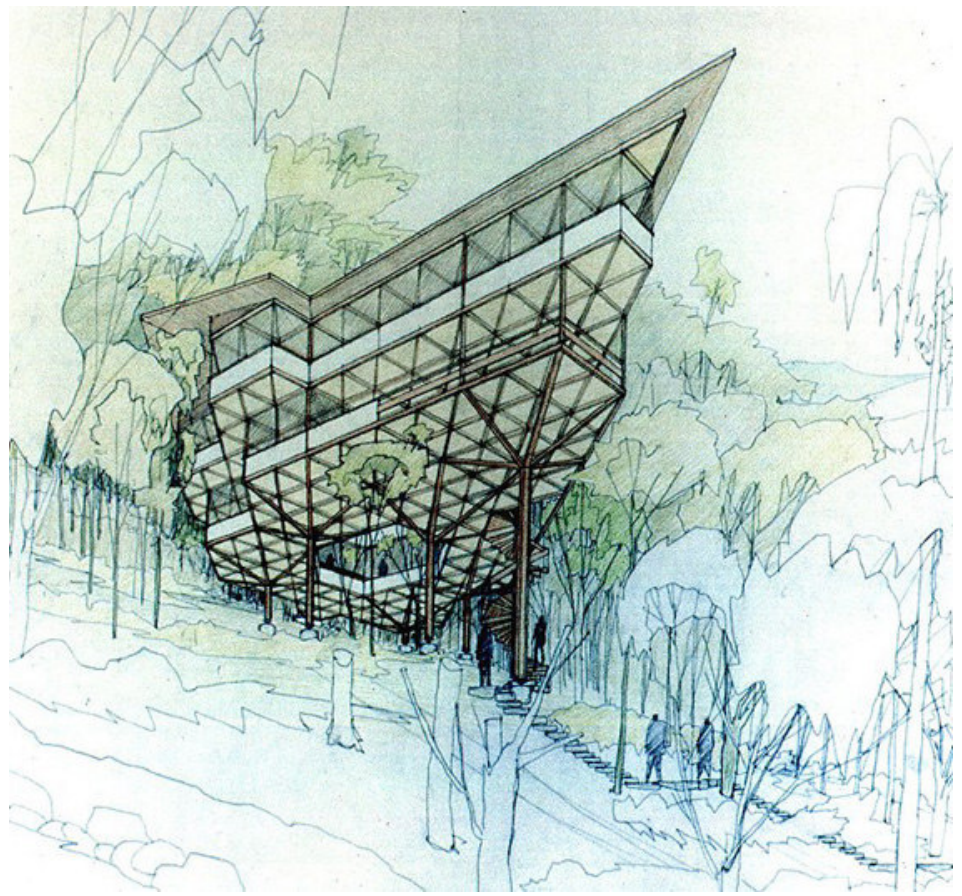

Fig. 3.15: Perspectiva feita à mão (grafite e aquarela) por Acayaba para residência Baeta. (fonte: arquivo pessoal Marcos Acayaba)

Entre os arquitetos de sua geração, Acayaba foi um dos pioneiros dentre os raros que decidiram se aventurar no mundo da informática. Desde o início dos anos 90, utiliza o computador não só como forma de representação, mas também como forma de concepção e experimentação projetual.
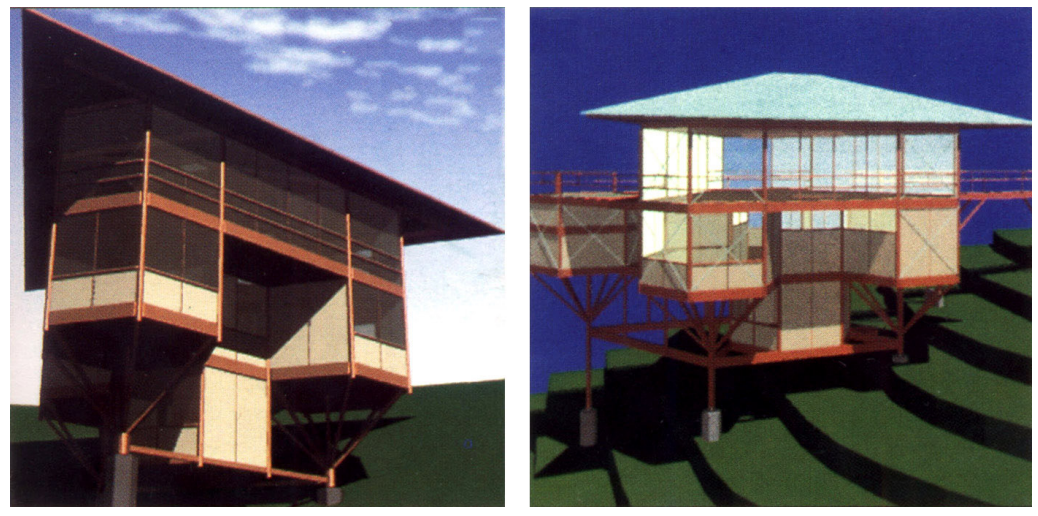

Fig. 3.16: Maquetes eletrônicas produzidas em ArchicAD. (fonte: arquivo pessoal Marcos Acayaba)

O depoimento que se segue foi dado pelo arquiteto à revista Projeto, em 1993, sobre o uso do, naquele momento, novo programa de desenho e modelagem virtual, o ArchiCAD:

Tenho conversado com muitos colegas sobre a informática, sobre esse programa, e noto que os mais velhos ou da minha geração ficam surpresos e dizem que vão colocar seus funcionários, seus estagiários, para aprender o novo recurso. 


\section{Capítulo 3}

Marcos Acayaba

Faço questão de dizer que isso é um grande engano. O computador não é um simples instrumento para produzir desenhos e projetos executivos. Ao contrário, é um instrumento de projeto, de concepção. Quem deve operá-lo é o próprio arquiteto, o criador da proposta (A MÁQUINA..., 1993. p. 60).

No início, o arquiteto usava o ArchiCAD apenas como forma de estudo e representação em 3D. Somente a partir de 1996-97, passou a utilizá-lo também para realização de projetos executivos (informação verbal) ${ }^{4}$.

Mesmo com o advento do computador, as "antigas" técnicas de estudo e representação não foram deixadas de lado. O croqui não deixou de ser a primeira materialização da idéia, a forma de estudo mais fácil e imediata.
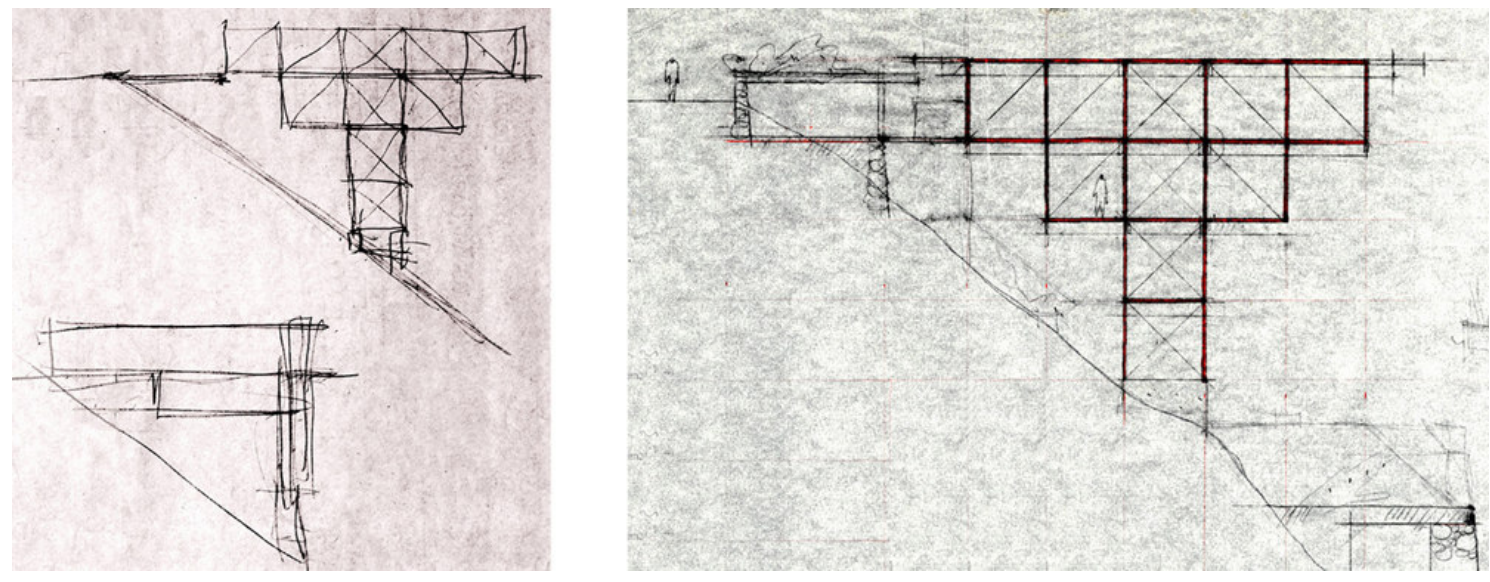

Fig. 3.17: Croquis para projeto da Residência Hélio Olga. (fonte: arquivo pessoal Marcos Acayaba)

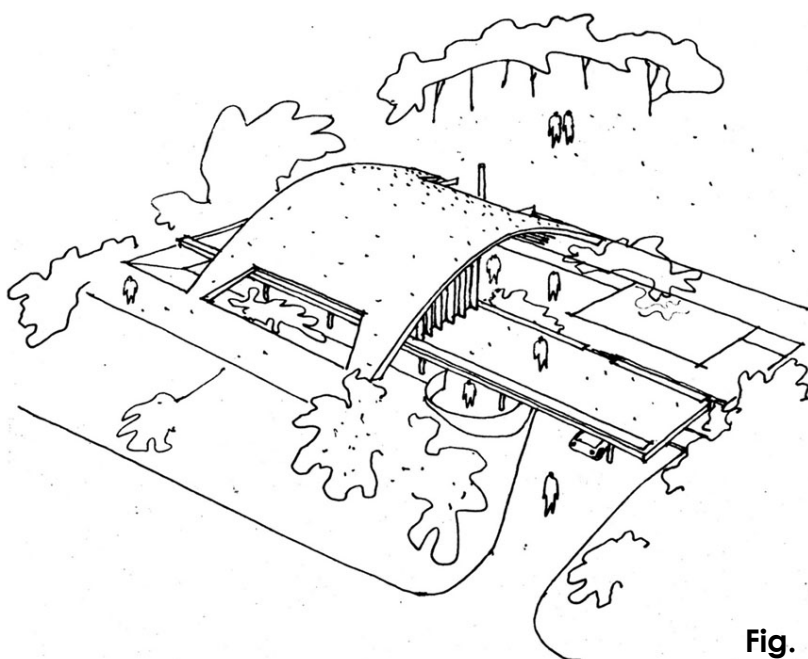

Fig. 3.5: Croqui para projeto da Residência

Milan. (fonte: MARCOS ACAYABA ARQUITETOS, 2007)

\footnotetext{
${ }^{4}$ Essa informação foi dada por Acayaba em visita ao seu estúdio, quando apresentou alguns projetos executivos desenvolvidos à mão.
} 
Capítulo 3

Marcos Acayaba

Um dos mais premiados projetos de Acayaba foi o Pavilhão Pindorama, cujo partido arquitetônico surgiu de uma experimentação com uma maquete de cartolina pintada a guache feita pelo próprio arquiteto.

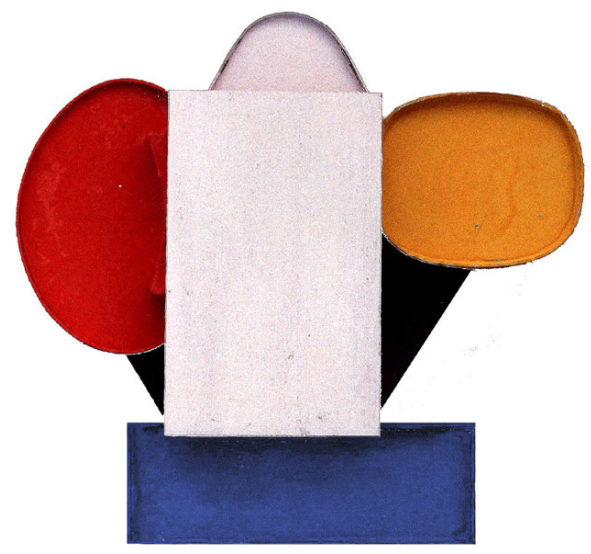

Fig. 3.6: Maquete feita por Acayaba para estudo do Pavilhão Pindorama.

(fonte: MARCOS ACAYABA ARQUITETOS, 2007)

O sistema desenvolvido para a série de casas de estrutura pré-fabricada de madeira foi estudado por meio de modelagem virtual em computador (maquetes eletrônicas) e de protótipos construídos em várias escalas, em parceria com o engenheiro Hélio Olga.

Os protótipos em madeira, construídos em várias escalas, inclusive 1:1, permitiram estudar os esforços sobre a estrutura e principalmente os encaixes entre as peças, ajudando a identificar os problemas e as dificuldades que poderiam incidir na execução da obra.

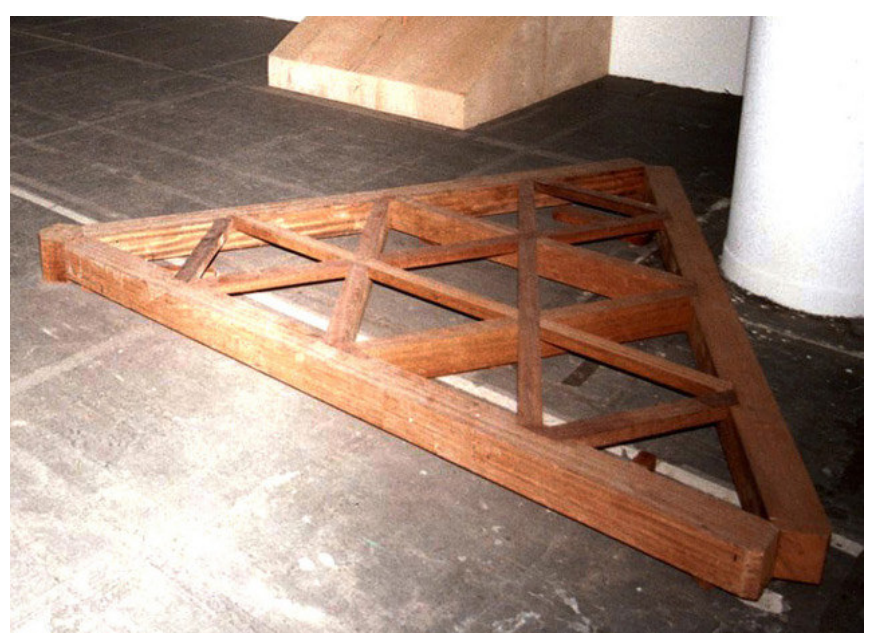

Fig. 3.20: Modelo em escala 1:1 da malha triangular de piso. (fonte: arquivo pessoal Marcos Acayaba) 
Capítulo 3

Marcos Acayaba
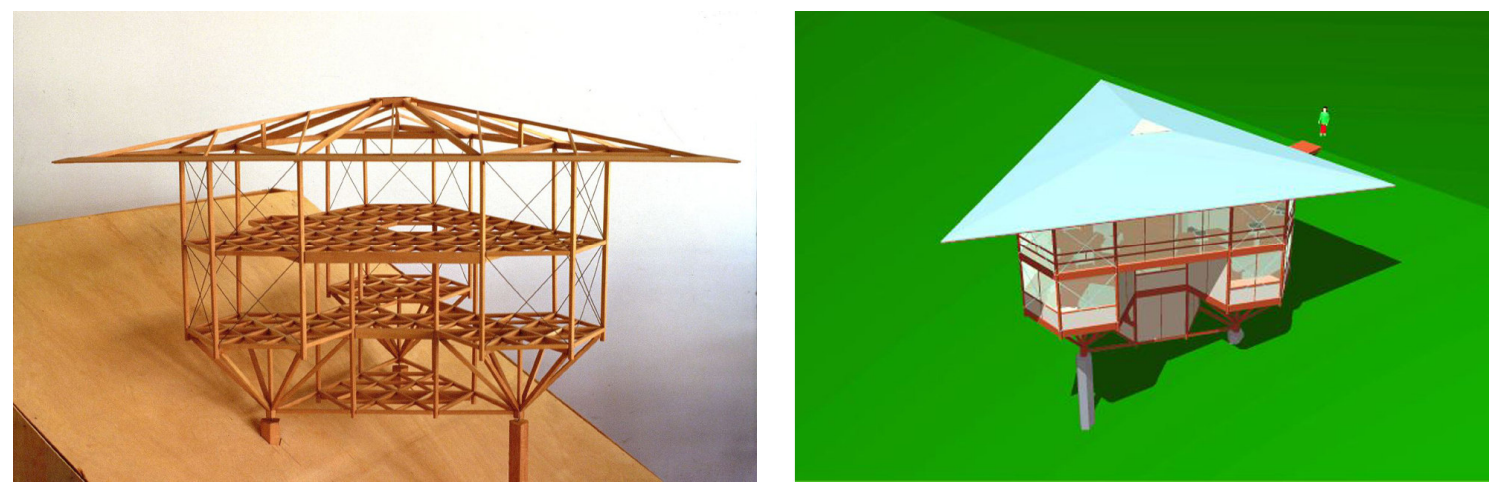

Fig. 3.21: Modelo em escala 1:15 e maquete eletrônica para estudo de estrutura em madeira pré-fabricada. (fonte: arquivo pessoal Marcos Acayaba)

A maquetes eletrônicas permitem a prévia visualização do edifício, auxiliando o estudo da espacialidade, da volumetria e da implantação do edifício. Acaba facilitando também a apreensão do projeto pelo cliente.

Outro ponto vantajoso, segundo Acayaba (2007), é que também podem ser realizados estudos de insolação a partir da inserção da longitude e da latitude do local de implantação, permitindo verificar com certa precisão a posição do sol em relação ao edifício ao longo do dia e das estações do ano. Esses estudos acabam sendo determinantes no projeto arquitetônico na medida em que auxiliam em certas escolhas como, por exemplo, a utilização ou não de elementos de proteção solar, seu desenho e suas dimensões, além do tamanho das aberturas, dos peitoris e dos beirais. As simulações das sombras também podem influenciar, por exemplo, na locação de uma piscina, evitando que seja colocada em área de sombra constante provocada por construções vizinhas ou pelo próprio edifício. 
Capítulo 4

Residência Milan

\section{CAPÍTULO 4:}

\section{RESIDÊNCIA MILAN (São Paulo - SP, 1972-1975)}

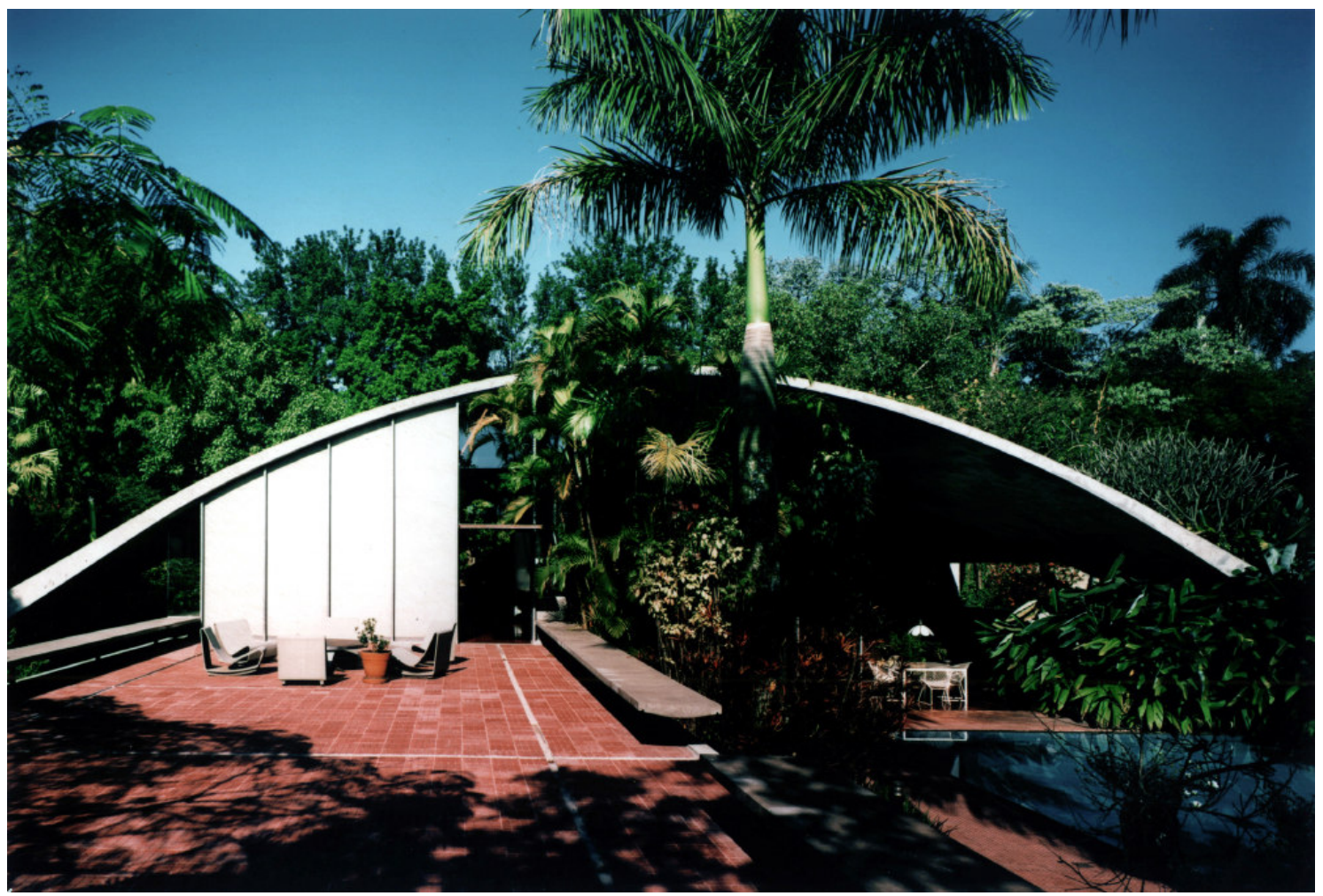

Fig. 4.1: Residência Milan. Vista frontal a partir do pátio. (fonte: arquivo pessoal Marcos Acayaba) 


\section{Capítulo 4}

Residência Milan

\subsection{O projeto}

O programa da Residência Milan previa uma casa de cerca de 450 m², num terreno de 2050,0 m², o que permitia a criação de espaços internos integrados e um grande jardim.

A idéia era valorizar a paisagem e ao mesmo tempo estabelecer um maior contato entre o interior da casa e todo o terreno, seguindo os conceitos de espaço mínimo e integração dos espaços internos, com os quais trabalhavam os arquitetos modernos nesse período.

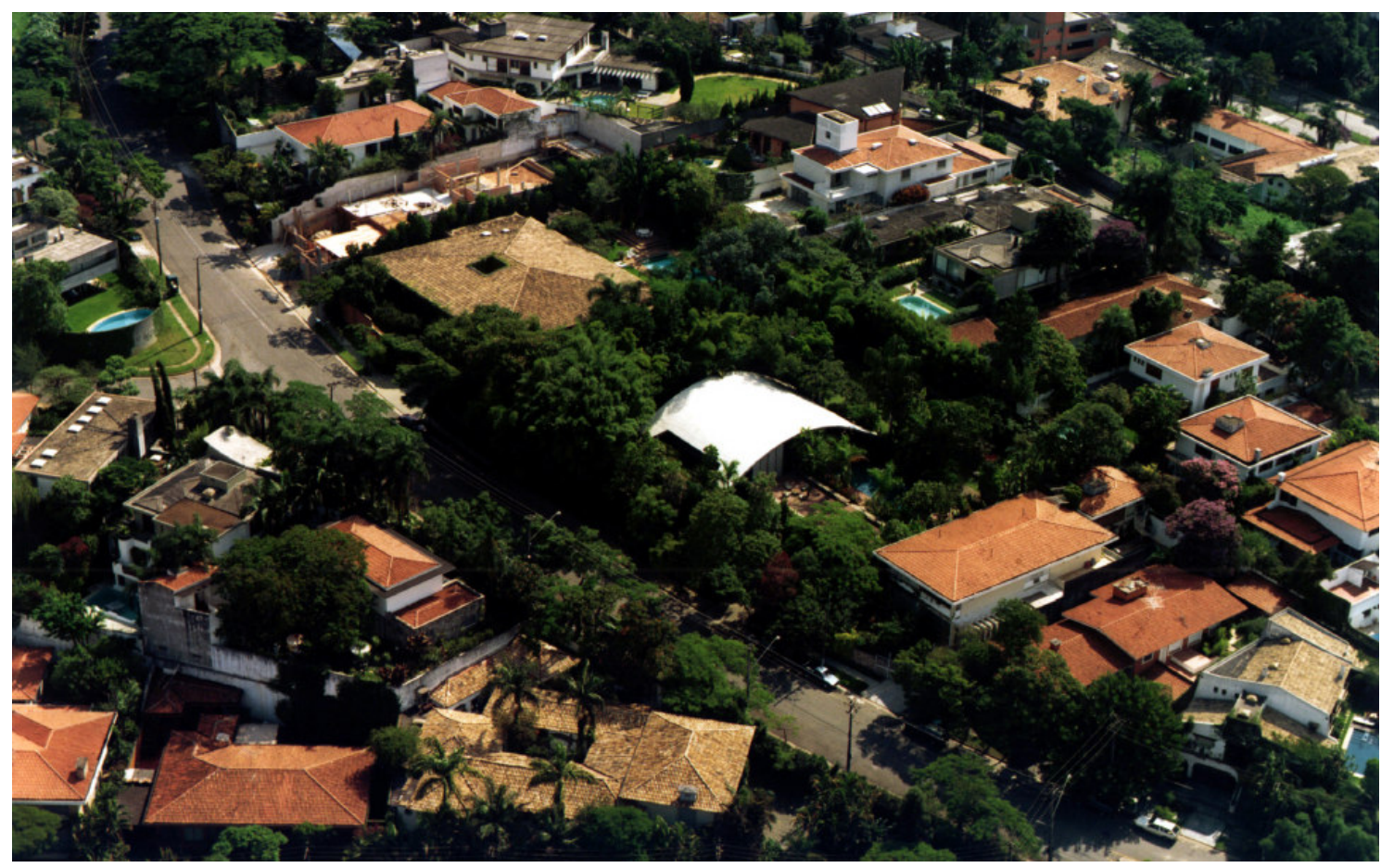

Fig. 4.2: Residência Milan. Vista aérea. (fonte: arquivo pessoal Marcos Acayaba)

A casa se articula em três meios níveis, com uma grande laje transversal à cobertura, criando uma organização funcional do programa. Na área central, no desnível, dois volumes de concreto abrigam os quatro banheiros e as duas caixas d'água. 


\section{Capítulo 4}

Residência Milan

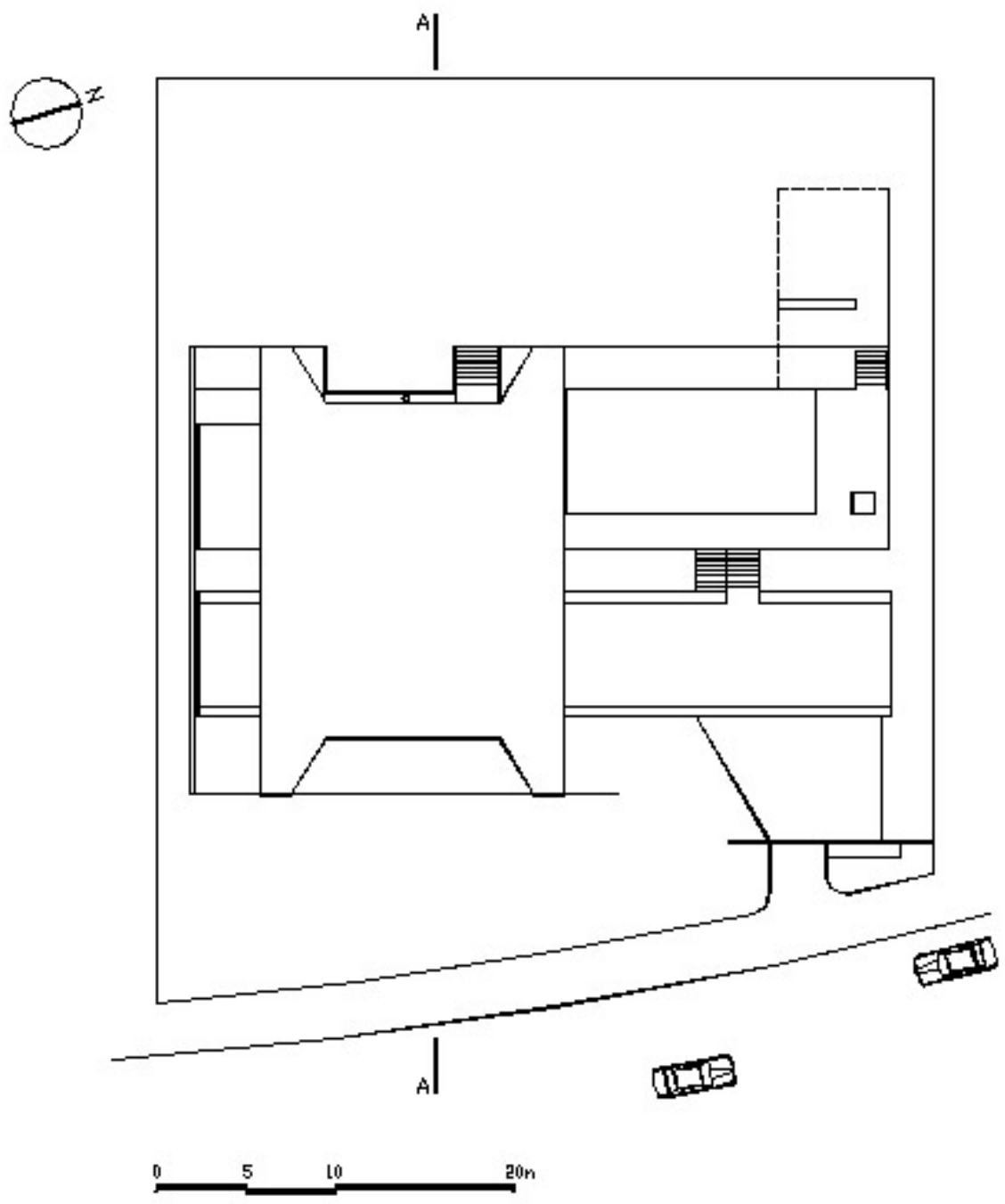

Fig. 4.3: Residência Milan. Implantação. (fonte: arquivo pessoal Marcos Acayaba)

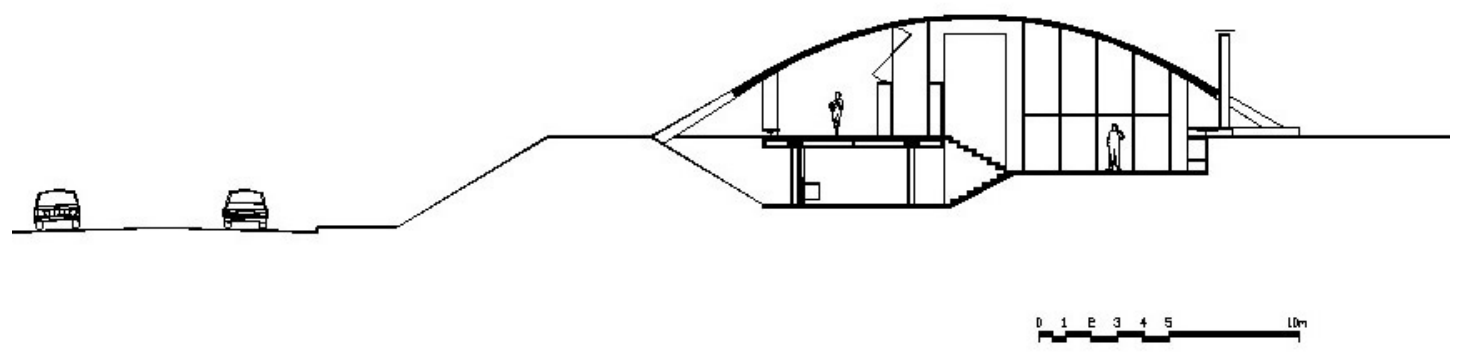

Fig. 4.4: Residência Milan. Corte transversal. (fonte: arquivo pessoal Marcos Acayaba) 


\section{Capítulo 4}

Residência Milan

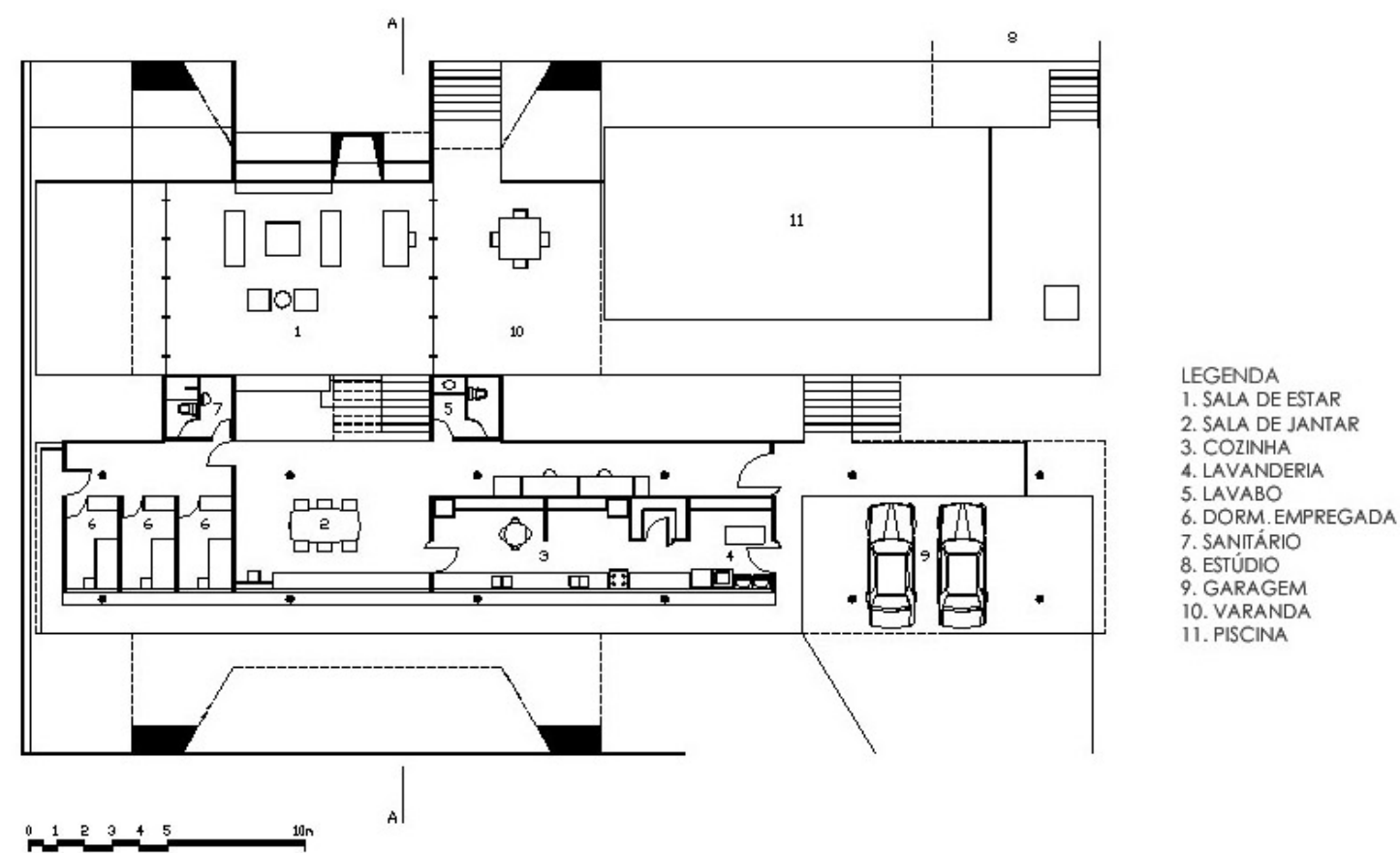

Fig. 4.5: Residência Milan. Planta pavimento térreo. (fonte: arquivo pessoal Marcos Acayaba)

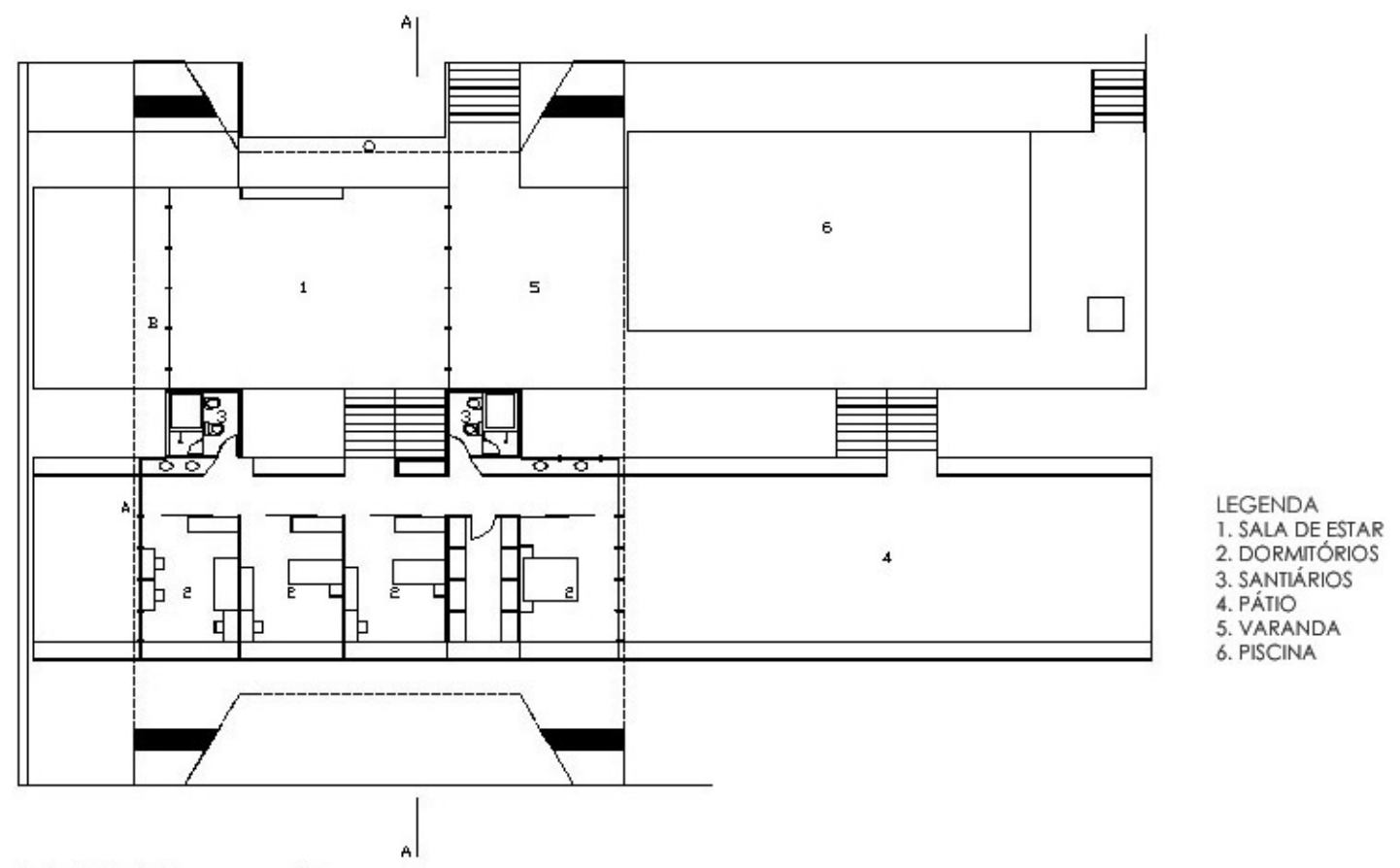

Fig. 4.6: Residência Milan. Planta pavimento superior. (fonte: arquivo pessoal Marcos Acayaba) 
Capítulo 4

Residência Milan
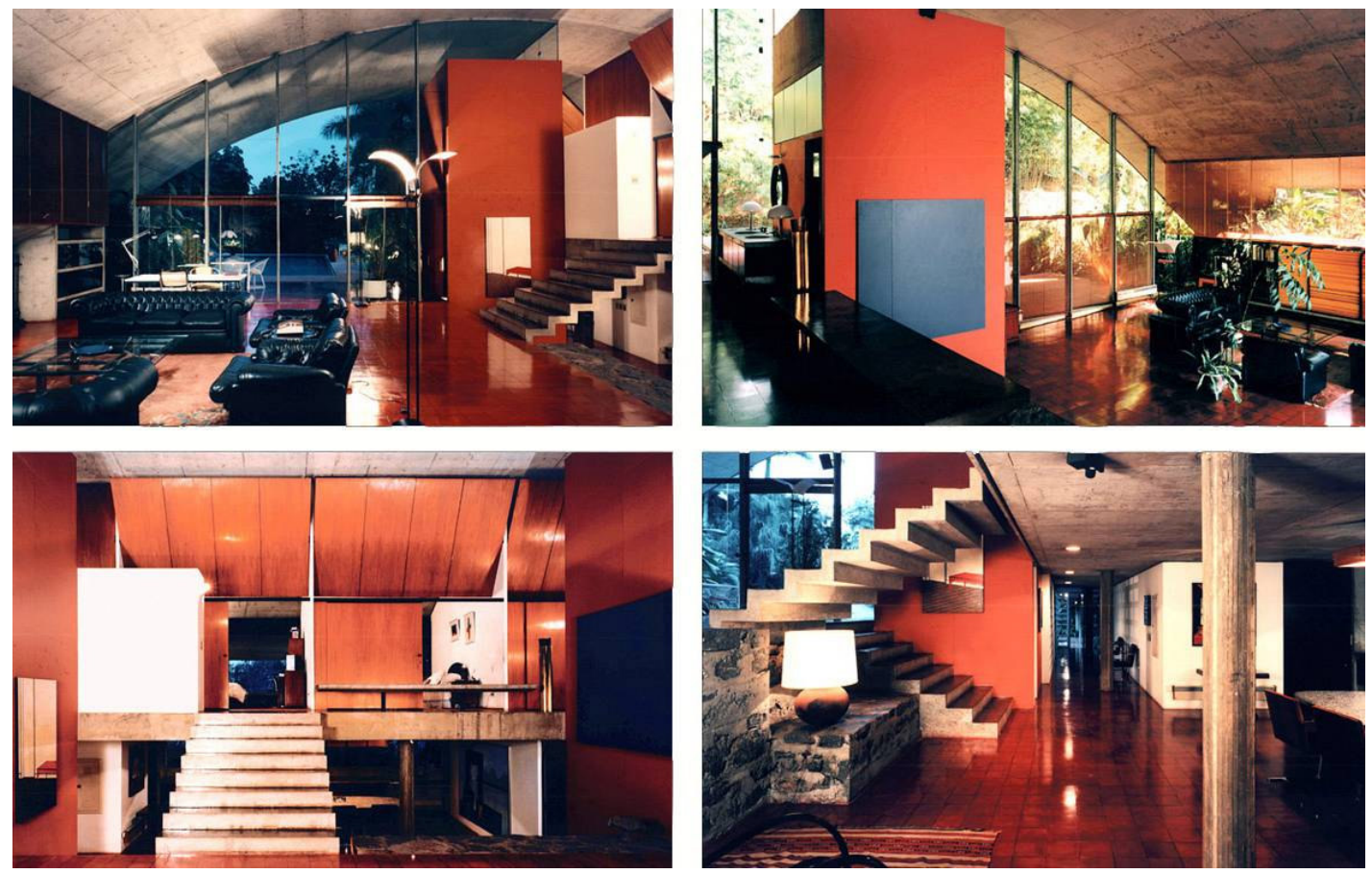

Fig. 4.7: Vistas internas. Acima: sala de estar. Abaixo, à esquerda: entrada dos dormitórios. À direita: sala de jantar. (fonte: arquivo pessoal Marcos Acayaba) 
Capítulo 4

Residência Milan

\subsection{A solução construtiva - Casca em concreto armado}

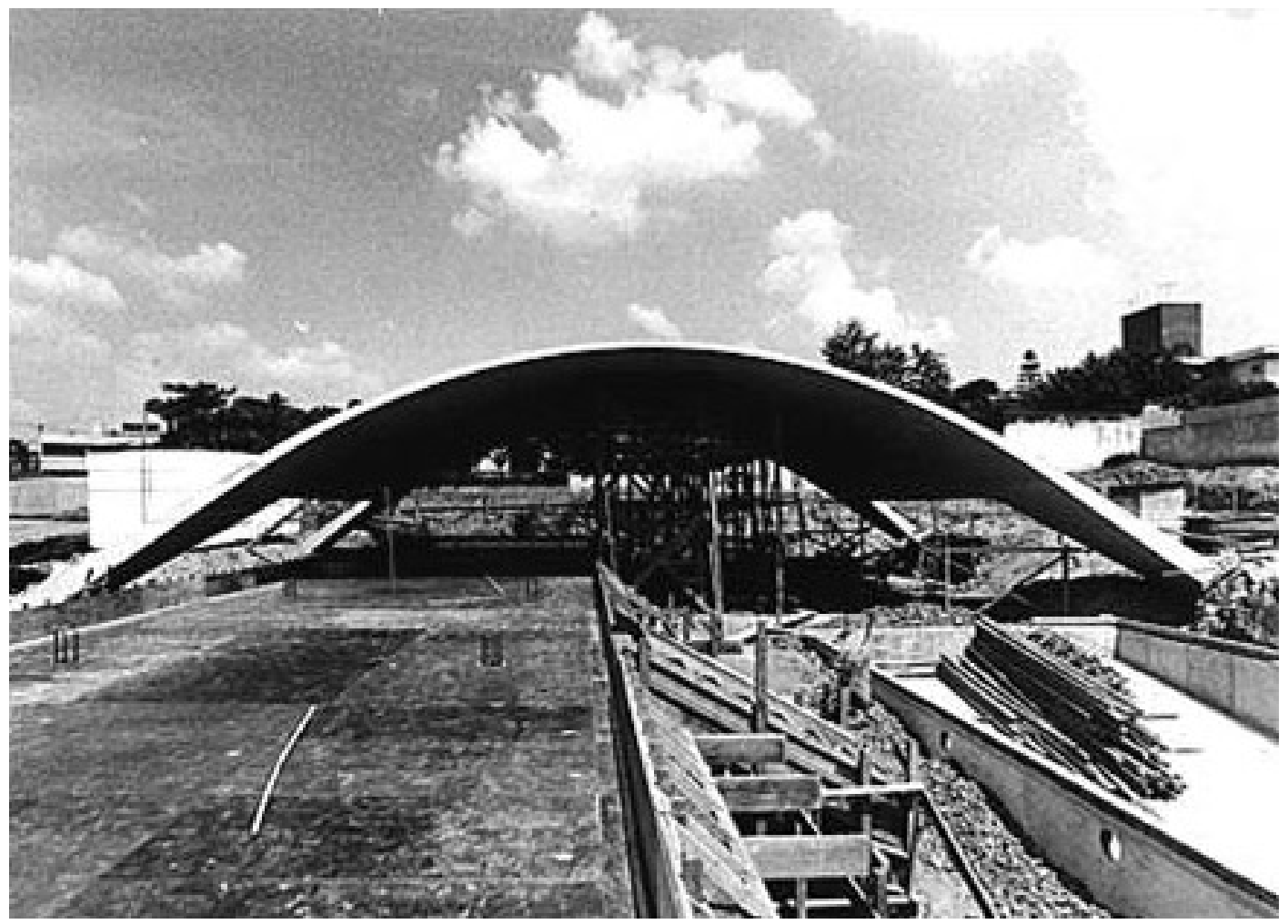

Fig. 4.8: Construção residência Milan. Retirada do cimbramento. (fonte: arquivo pessoal Marcos Acayaba)

Quando foi convidado para fazer o projeto dessa casa, para sua cunhada, Acayaba ainda era um jovem arquiteto recém formado. Em conversa informal, o arquiteto revelou que a admiração pelo arquiteto Oscar Niemeyer desde a infância teve forte influência na escolha do partido a ser adotado para a casa.

Acayaba (2004) aponta que uma de suas maiores inspirações foi o Clube Diamantina, realizado nos anos de 1950, por Niemeyer. O projeto consistia numa casca em arco apoiada em quatro pontos sobreposta a uma laje alongada no seu sentido longitudinal. 
Capítulo 4

Residência Milan

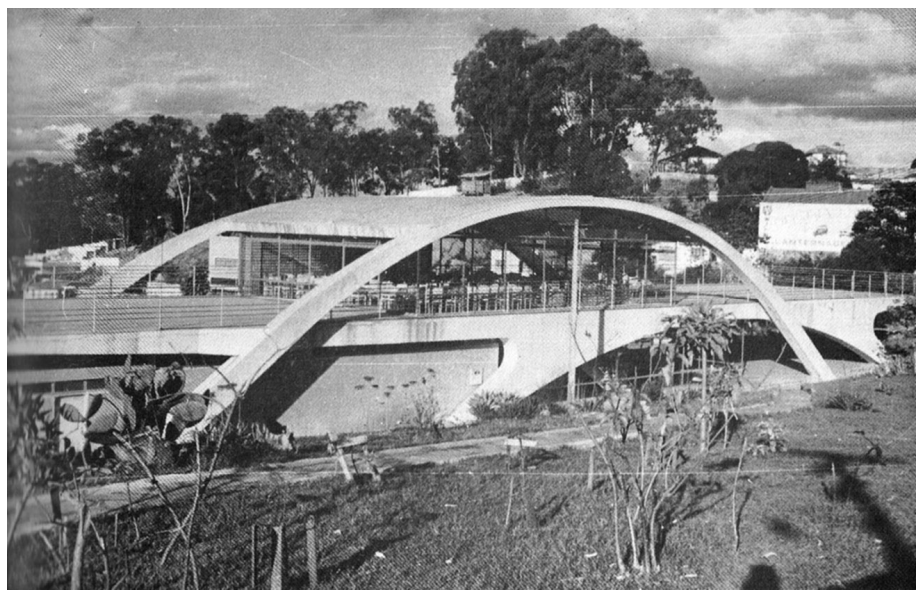

Fig. 4.9: Clube Diamantina, 1950. De Oscar Niemeyer. Casca em concreto armado. (fonte: BRUAND, 1999, p.159)

No período em que esse projeto foi desenvolvido, além de Niemeyer, outros arquitetos também estavam fazendo experiências com coberturas em abóbada. Como é o caso de Sérgio Ferro que, apesar de trabalhar com a mesma linguagem, pregava a utilização de técnicas construtivas baseadas na manufatura, com materiais baratos e tradicionais.

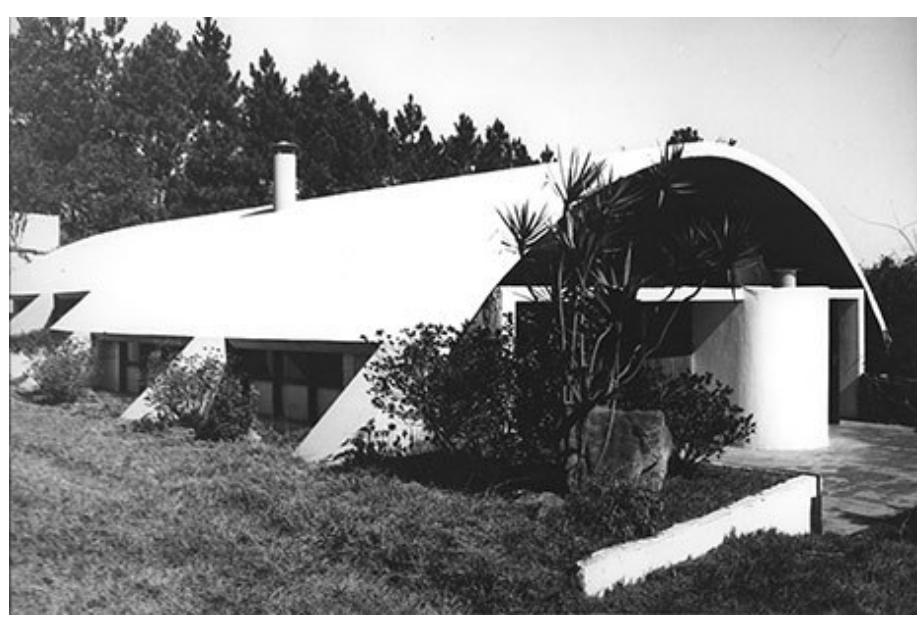

Fig. 4.10: Residência em Cotia, 1964. Sérgio Ferro. "Uma abóbada circular construída de vigas retas de tijolo furado, com o auxílio de cambotas simples de madeira". (fonte: LIMA, 2007, p. 44)

Acayaba acabou adotando a tecnologia do concreto armado. Naquele momento, o concreto armado estava sendo utilizado em larga escala. Era símbolo da arquitetura contemporânea e permitia uma forte expressividade.

Com a deferência de Oscar Niemeyer e sua apologia do material como suporte ideal para suas elaborações plásticas, o concreto armado tornou-se uma solução recorrente e imbatível entre os arquitetos alinhados ao pensamento da "escola". Enfim, o concreto transformou-se na expressão contemporânea da técnica construtiva brasileira (SEGAWA, 1999, p.149). 
Capítulo 4

Residência Milan

A cobertura curva foi executada em concreto armado fundido "in-loco", com espessura variável, abrangendo uma área em planta de 25,0 m x 17,0 m.

Com ângulos de arranque de $30^{\circ}$, apóia-se nas extremidades do terreno e é atirantada nas sapatas de fundação.

O vão livre entre as sapatas é de $33,0 \mathrm{~m}$. Seu desenho surgiu a partir de dois arcos de círculo de raios diferentes com tangentes seguindo suas extremidades, como mostra o croqui a seguir:

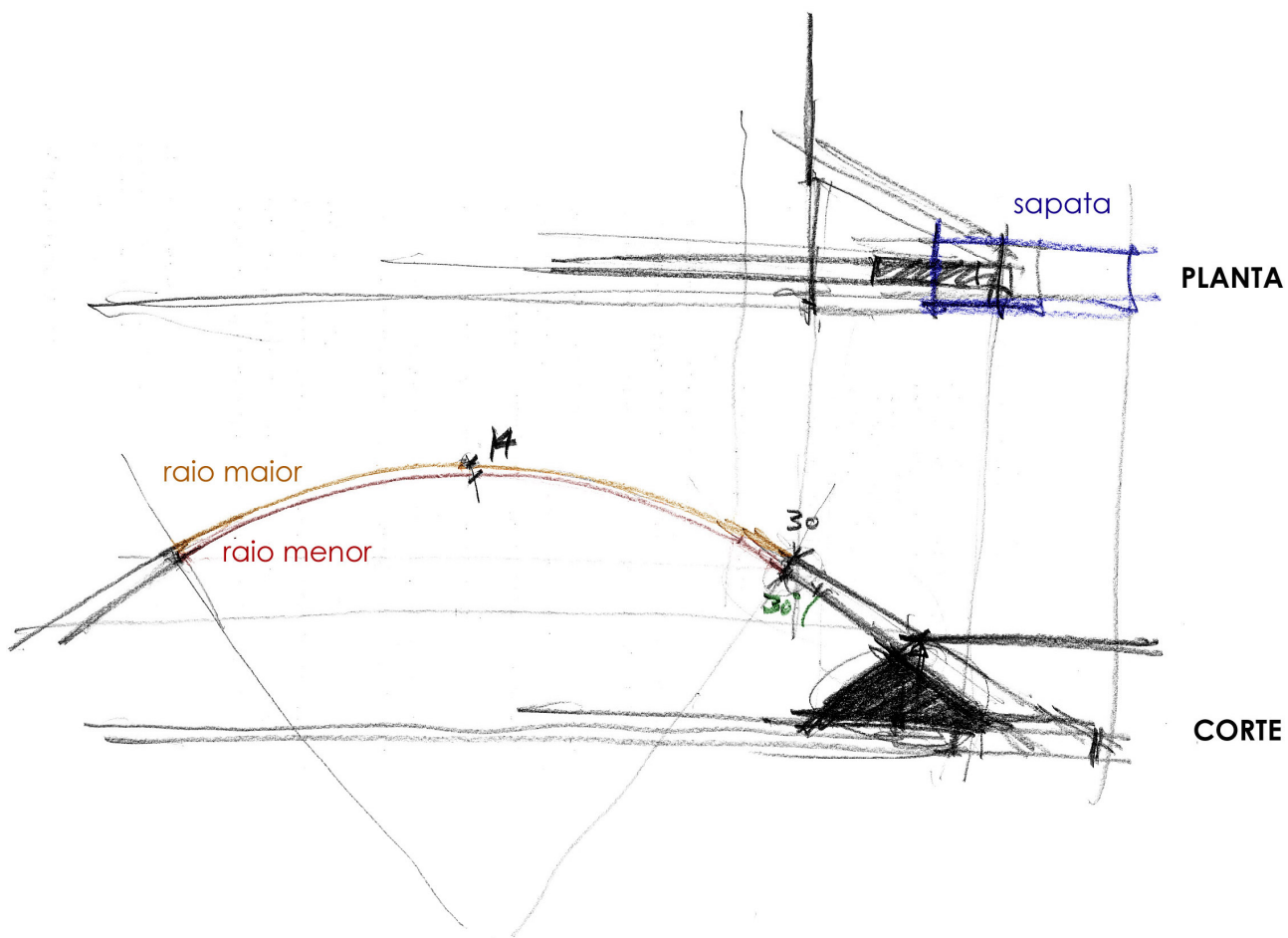

Fig. 4.11: Croqui feito por Acayaba e colorido digitalmente para indicar construção da curva a partir de dois raios e ângulos de arranque de $30^{\circ}$. (fonte: autora)

Foram utilizadas fôrmas de madeira, inclusive para a parte superior da casca. $E$ o concreto foi lançado por bombeamento. Sua execução foi complicada, pois exigia fôrmas de madeira complexas e artesanais, com um cimbramento' muito denso e que depois foram descartadas, além da utilização de uma técnica até então nova no Brasil, a do bombeamento e lançamento do

1 "O cimbramento é a estrutura provisória [...] que sustenta as fôrmas que vão receber e dar forma ao concreto ainda mole (pastoso). Quando o concreto inicia a pega, ele adquire uma determinada resistência que permite a retirada do cimbramento e das fômas" (BOTELHO, 1983, p.286). 
Capítulo 4

Residência Milan

concreto em altura, "uma sofisticação que eu não sei se caberia na obra de uma residência" (ACAYABA, 2004, vol. 1, p.24).

A curva adotada não é uma catenária, portanto não trabalha somente à compressão. Logo após a retirada do cimbramento foram detectadas fissuras nos quatro apoios da casca.

A solução foi fazer reforços prismáticos em concreto nos quatro apoios e atirantar as sapatas entre si, formando um quadrilátero de tirantes protendidos.
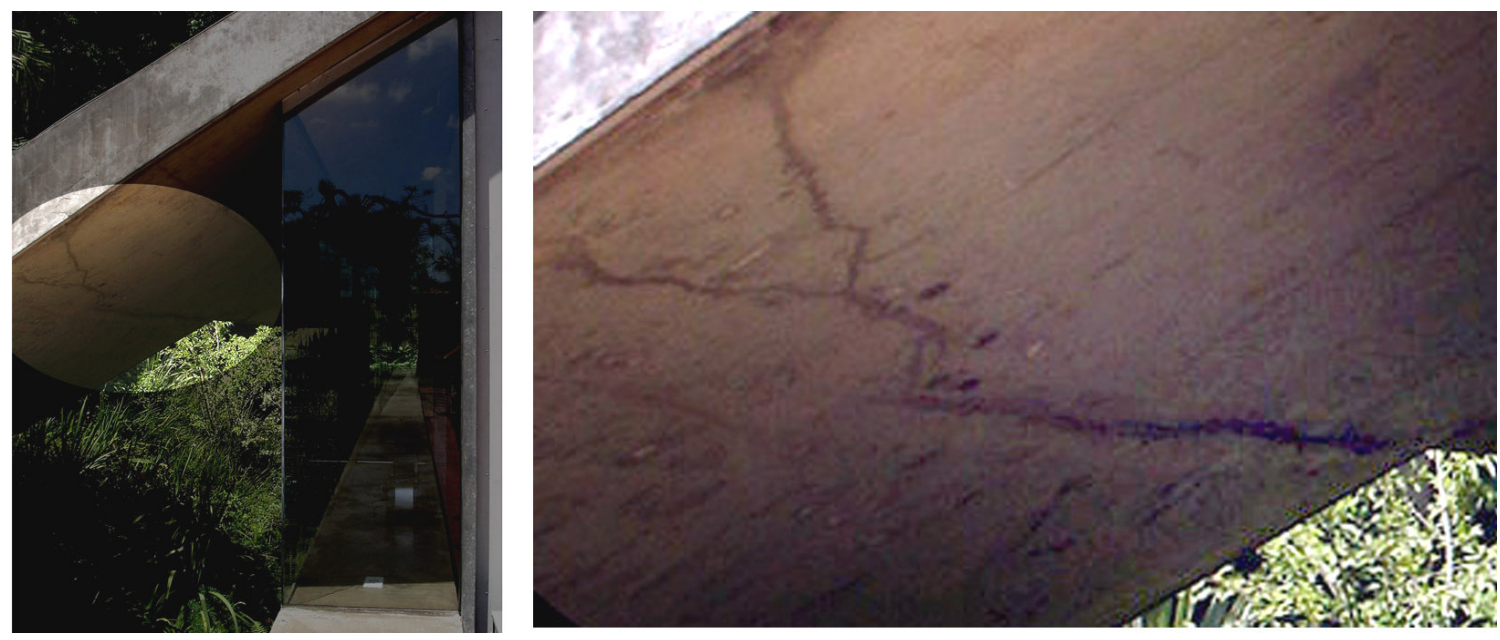

Fig. 4.12: Fissuras num dos pontos de apoio da casca. (fonte: autora)

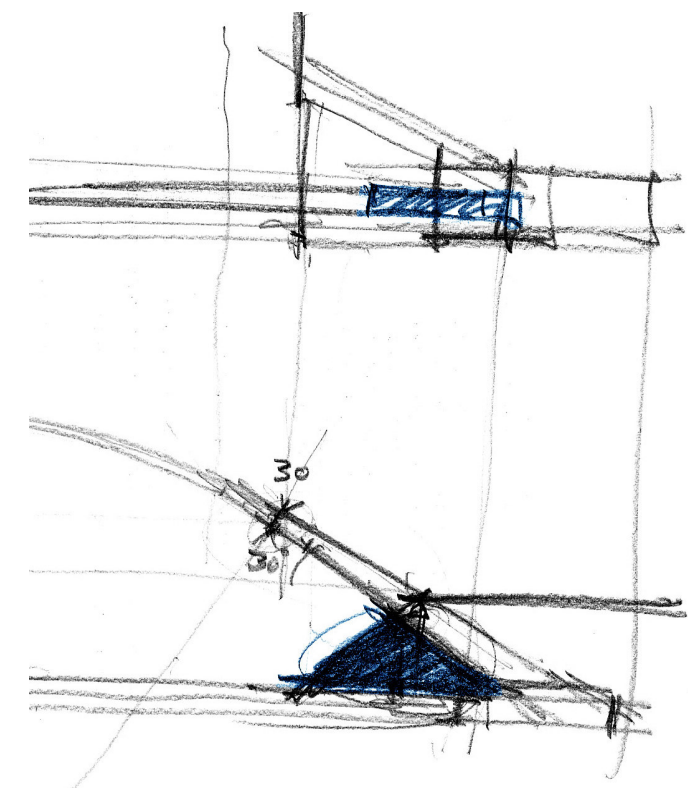

PLANTA Marcos Acayaba, editado pela autora. (fonte: autora) 


\section{Capítulo 4}

Residência Milan

A curva catenária pode ser conformada através da "[...] forma adquirida por um cabo de massa uniformemente distribuída, quando sujeito somente à ação do seu peso" (SILVA, 2003, p. 31).

Lopes confirma essa afirmação e explica a utilização da catenária no Egito pelos núbios: "[...] os núbios construíam suas abóbadas seguindo uma geometria decalcada sobre a catenária: uma corda suspensa desenvolve, em si, uma curva catenária. Se uma corda se estabiliza comodamente aos esforços de tração segundo essa geometria, os núbios aprenderam que o mesmo deveria ocorrer ao contrário, quando utilizando materiais resistente à compressão[...]" (LOPES, 2006, p. 166).

A figura a seguir demonstra a diferença entre a curva adotada e a curva catenária lobtida através de uma corrente suspensa fixada pelas extremidades).

Em azul, apontam-se as zonas de maior solicitação à flexão em corte e em planta. Foi exatamente nesses pontos que a estrutura sofreu fissuras na retirada do cimbramento.

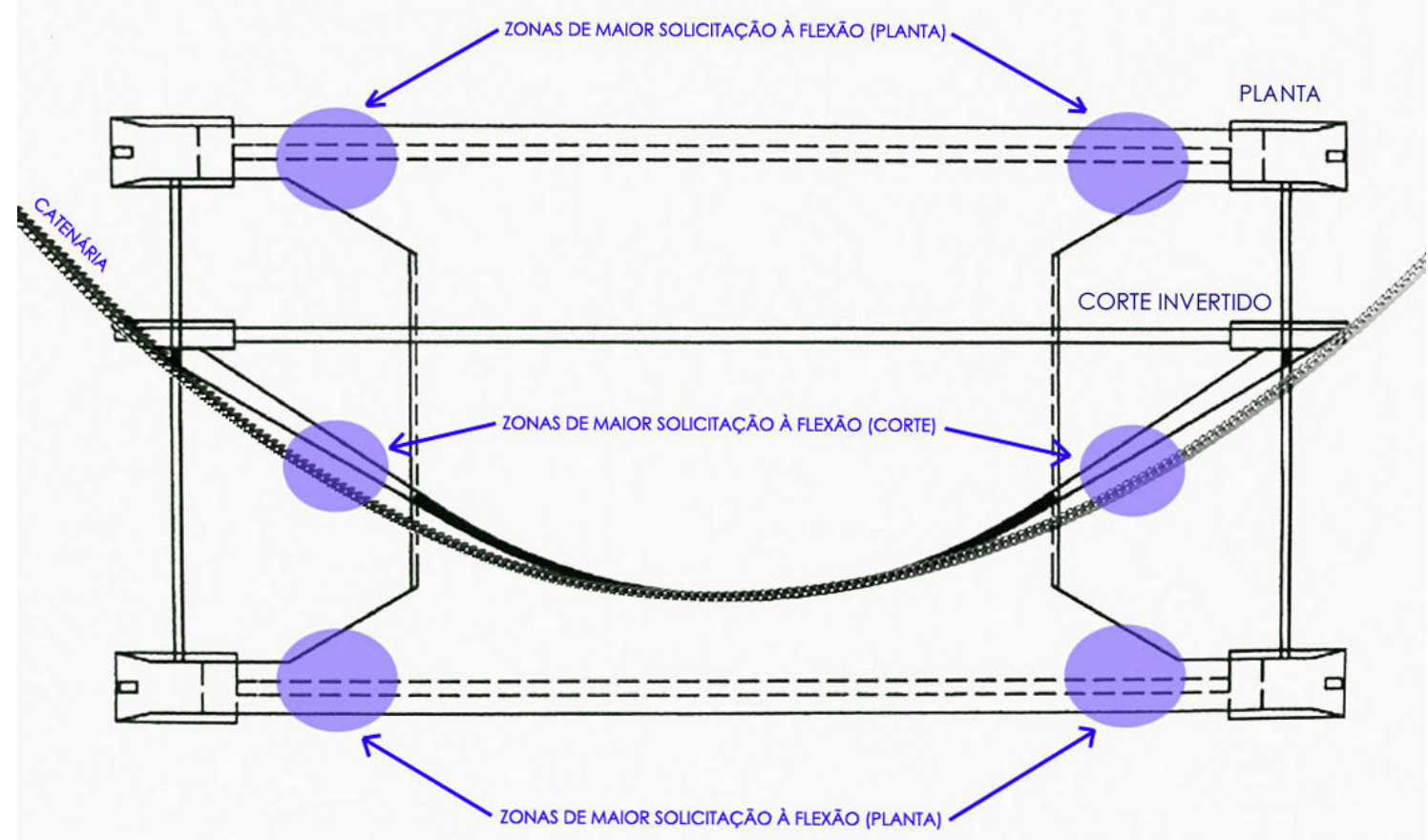

Fig. 4.14: Sobreposição planta e corte da fundação e estrutura, com catenária, indica zonas de maior solicitação à flexão. (fonte: autora) 


\section{Capítulo 4}

Residência Milan

Na parte central da casca, a curvatura comporta-se de maneira muito próxima a uma catenária. Nessa região não houve fissuras.

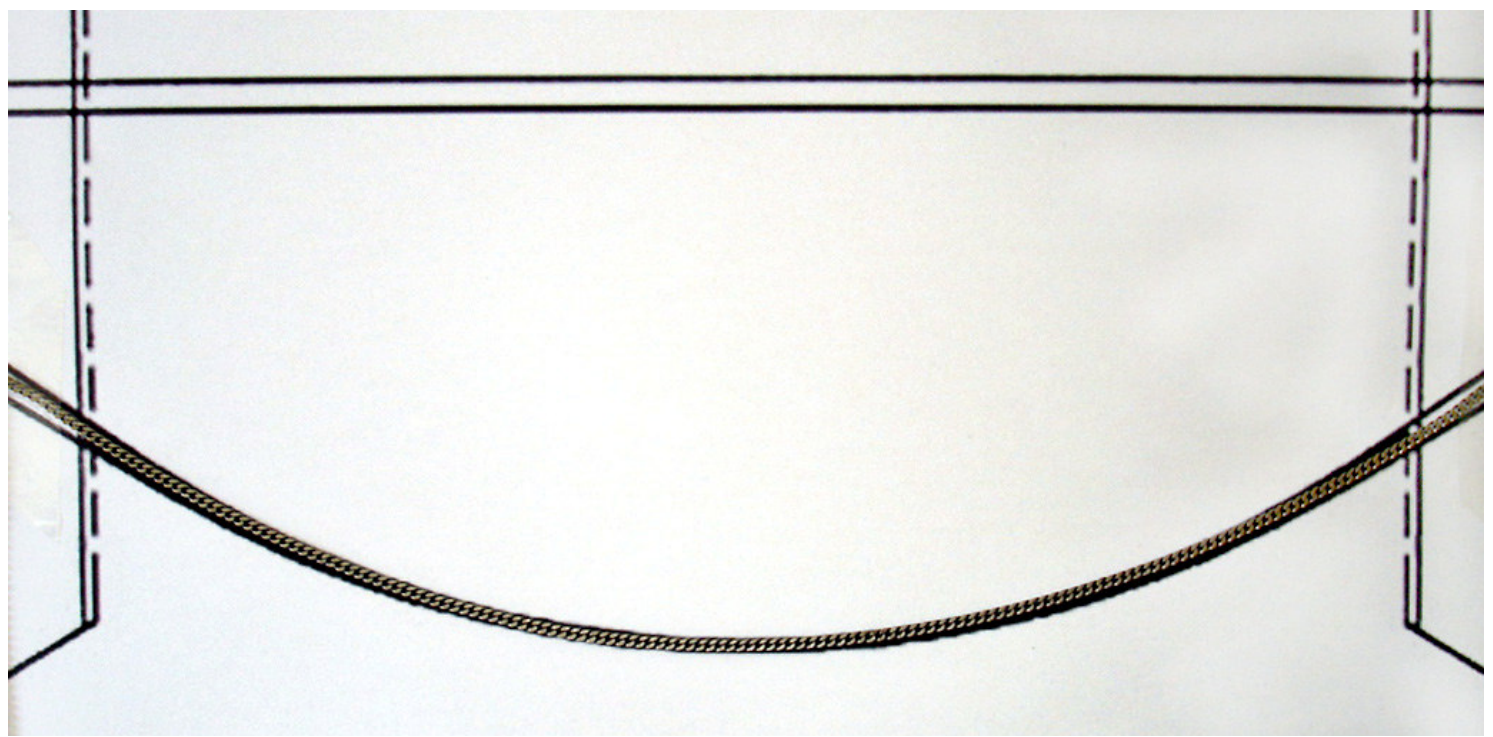

Fig. 4.15: Corrente em pêndulo indica a proximidade da parte central da curva com a catenária. (fonte: autora)

De acordo com Acayaba (2007), na face externa da casca foram coladas placas de poliuretano expandido de $2,0 \mathrm{~cm}$ de espessura e por sobre elas uma camada de manta de lã de vidro. Por cima da manta aplicou-se poliuretano líquido que, ao se fundir com as placas, formou uma camada única e sólida. Esse recurso visava auxiliar no isolamento térmico da edificação, mas exigia uma manutenção constante. A cada dois anos era necessário pintar a cobertura, pois sua a camada superficial descascava, mas sem formação de fissuras. Inicialmente era pintada com o próprio poliuretano mas, devido ao seu alto custo, passou-se a utilizar tinta acrílica.

Por volta de 1999-2000, mesmo sem nunca ter havido infiltrações ou vazamentos, Acayaba decidiu revestir a casca com uma manta termoplástica de impermeabilização², protegendo então o poliuretano e dispensando as constantes pinturas. O acabamento resultou muito satisfatório e o problema das manutenções muito freqüentes foi solucionado.

2 Conhecida comercialmente como Alwitra, essa manta termo-plática de impermeabilização também foi utilizada nas lajes de cobertura da residência Marcos Acayaba (ver capítulo 7). 
Capítulo 4

Residência Milan
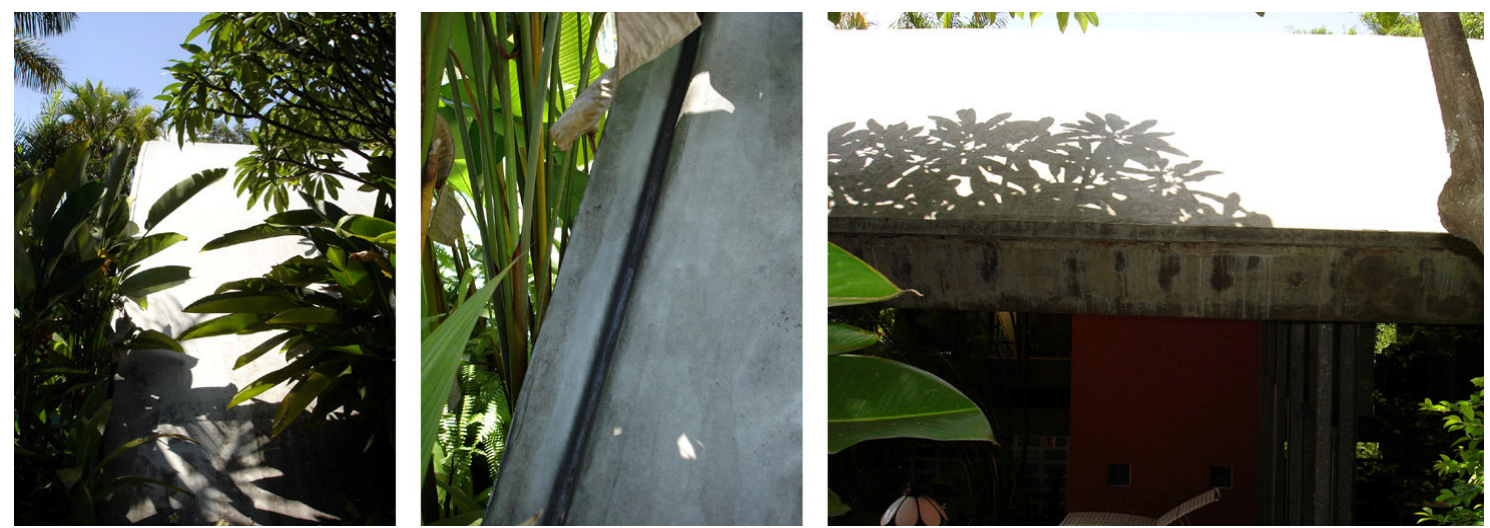

Fig. 4.16: Manta termo-plástica revestindo a cobertura. (fonte: autora)

Os caixilhos da residência são de aço galvanizado, estruturados por tubos retangulares de chapa de aço dobrada. Os montantes verticais não receberam nenhum tipo de pintura e, mesmo após mais duas décadas, não apresentam nenhum sinal de deterioração.

Segundo Acayaba, devido às grandes dimensões do pano de vidro e à necessidade de resistência à ação dos ventos, foram realizados diversos ensaios com o serralheiro Roberto Venturolli antes da montagem (informação verbal) ${ }^{3}$.
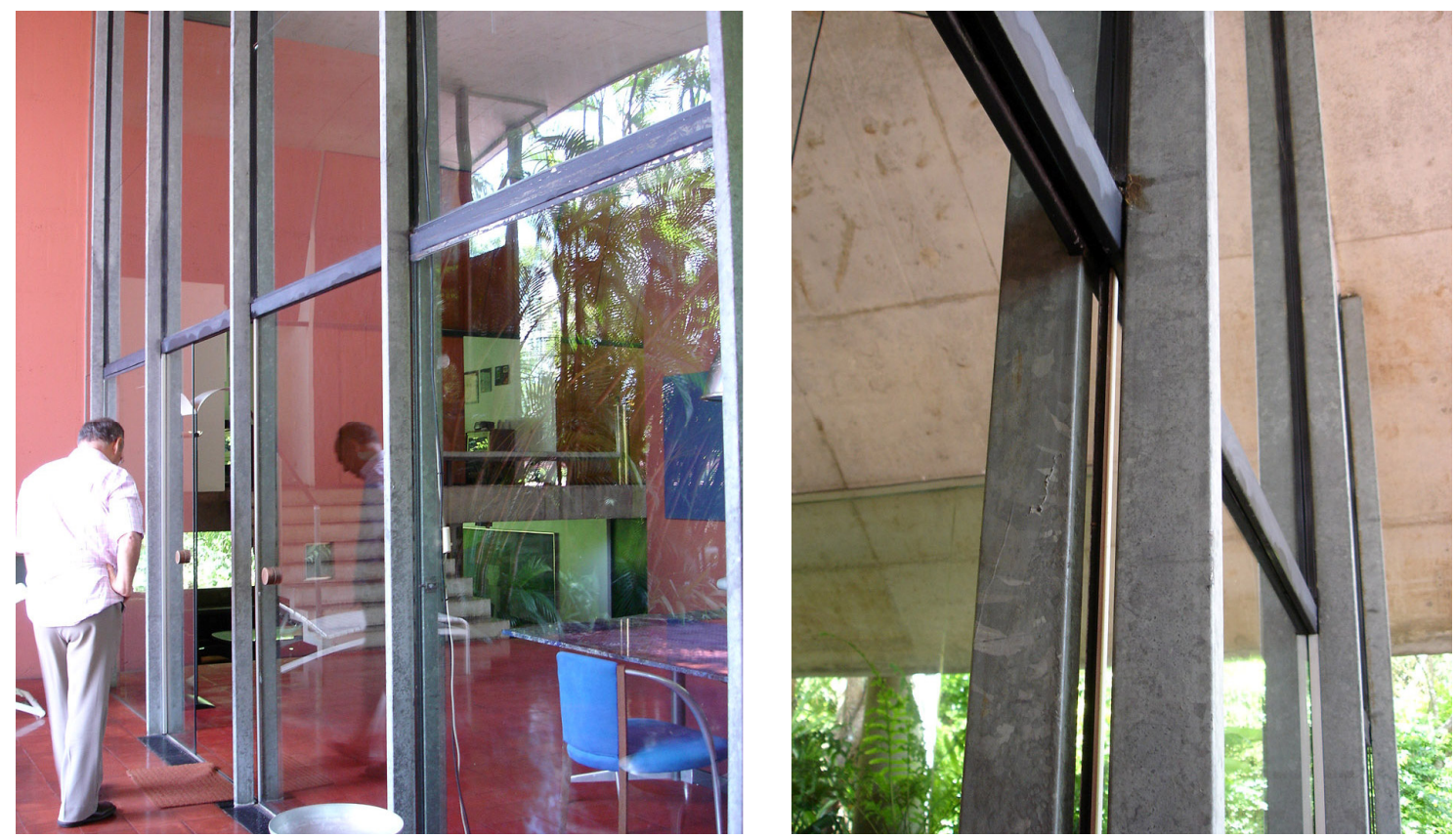

Fig. 4.17: Caixilhos em aço galvanizado e Marcos Acayaba. (fonte: autora)

\footnotetext{
3 Informação dada por Acayaba em visita à residência Milan, sua moradia atual.
} 
Capítulo 4

Residência Milan
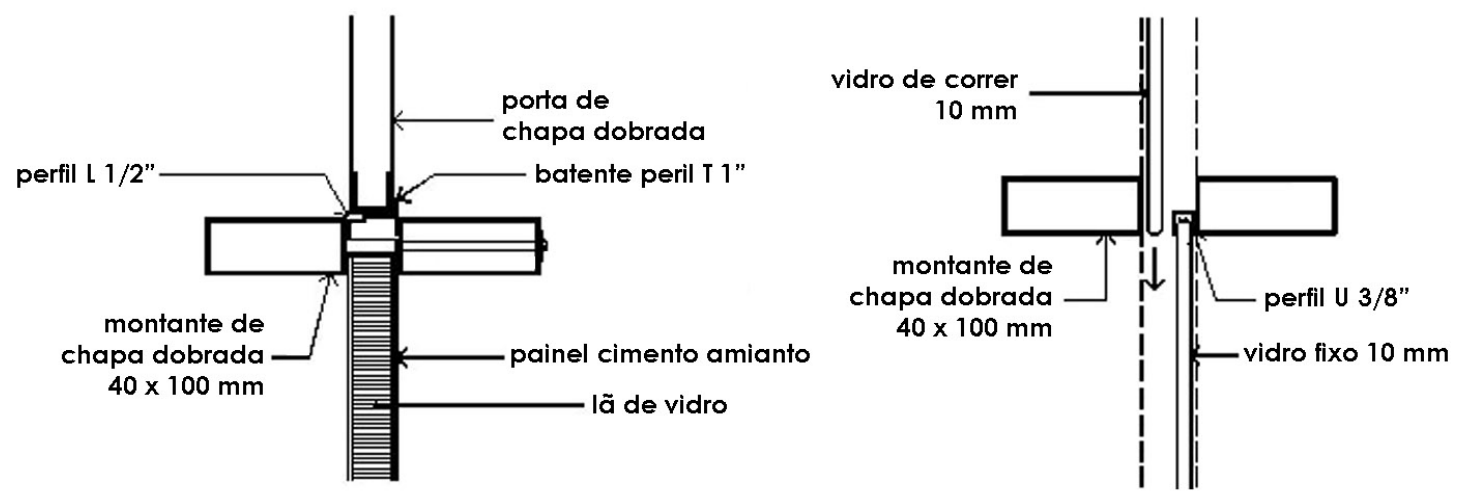

Fig. 4.18: Detalhes da caixilharia. Planta. (fonte: arquivo pessoal Marcos Acayaba - editada pela autora)

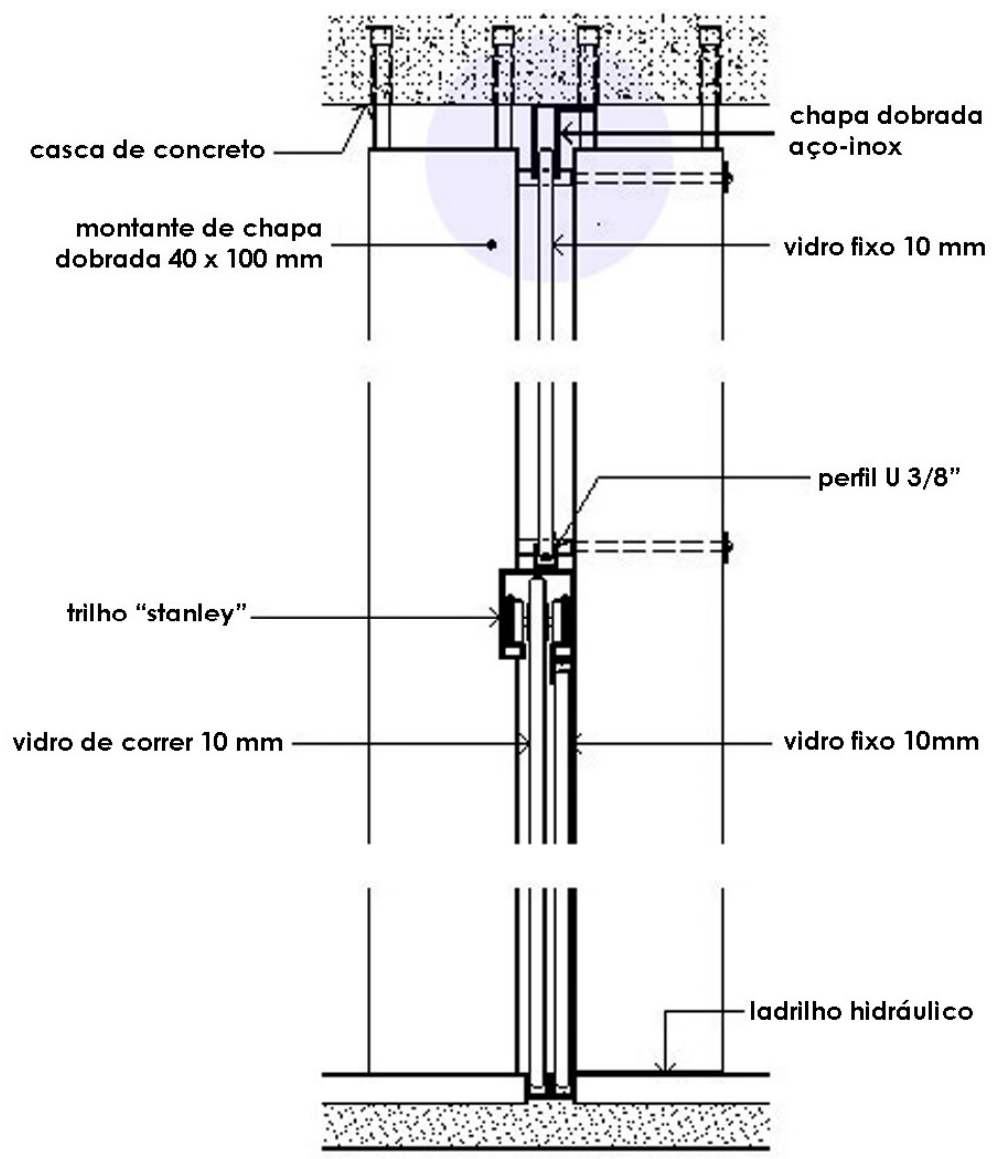

Fig. 4.19: Detalhes da caixilharia. Corte. Na fixação do caixilho na casca de concreto é prevista a movimentação vertical da estrutura através de perfis com encaixe flexível. (fonte: arquivo pessoal Marcos Acayaba - editada pela autora) 
Capítulo 4

Residência Milan
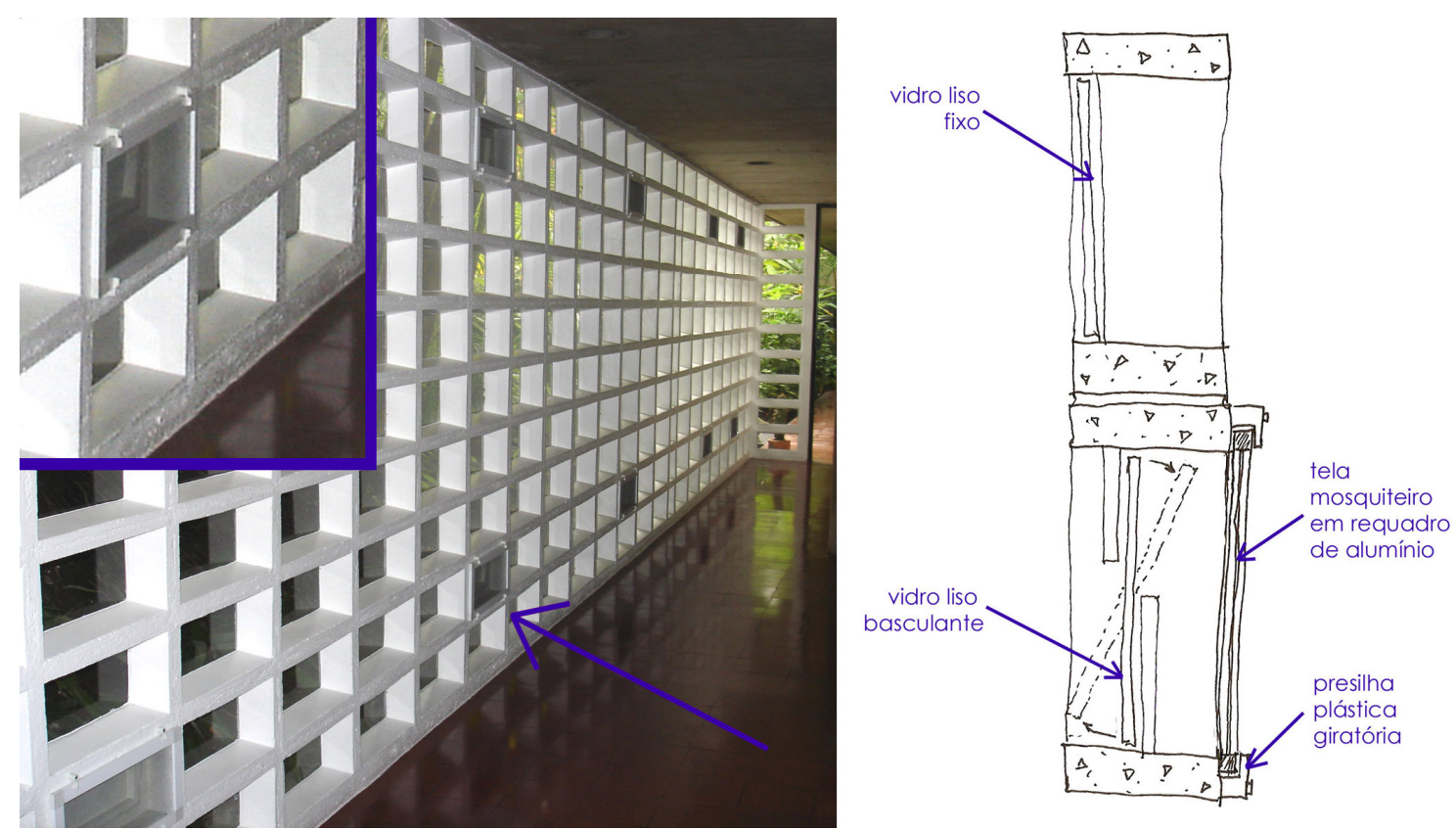

Fig. 4.20: Parede de elementos vazados, em concreto pré-moldado, no corredor de acesso da garagem para a sala de jantar. A maioria dos elementos recebeu vidros fixos, mas alguns receberam vidros basculantes associados a uma tela mosquiteiro em requadro de alumínio removível, permitindo ventilação permanente. (fonte: autora)

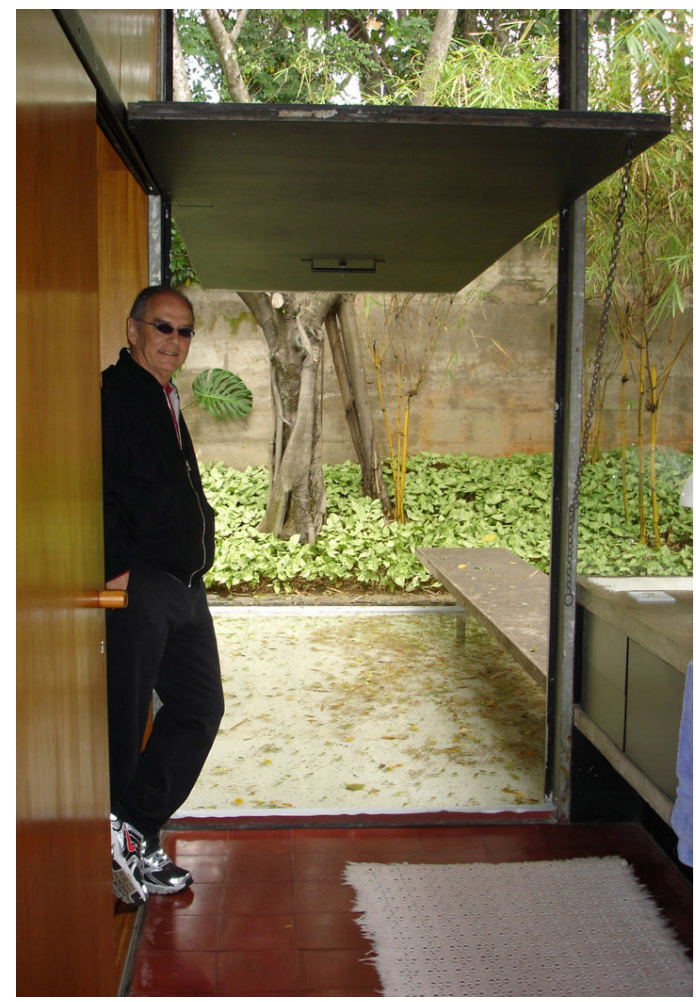

Fig. 4.21: Porta basculante transforma-se numa pequena marquise, marcando a saída para 0 terraço. Feita em perfis galvanizados, e revestida de chapa de aço galvanizado pintada, possui acionamento manual simples e é fixada na posição horizontal por meio de uma corrente metálica que se prende ao montante lateral. (fonte: autora) 


\subsection{Considerações sobre o projeto}

Acayaba realizou esse projeto em 1972. Tinha se formado há apenas três anos. Nesse período, as formas de Niemeyer, tão difundidas com a construção de Brasilia, cerca de uma década antes, ainda influenciavam fortemente a produção arquitetônica nacional.

Como admirador de Niemeyer desde a infância, não é à toa que Acayaba aproveitou sua primeira oportunidade de trabalhar com essa linguagem e adotou o mesmo partido construtivo utilizado por ele e pelos tantos mestres modernistas que estudou na faculdade.

Em entrevista cedida à autora, Acayaba (2006), quando questionado sobre a tecnologia do concreto armado, admite que "o concreto armado realmente é uma coisa muito sedutora como técnica porque qualquer forma que você conceba, dá pra fazer com concreto".

Porém, é preciso ressaltar, que a técnica construtiva utilizada nesse caso não se justificaria num projeto de residência devido a seu alto grau de sofisticação e custo ${ }^{4}$. Houve também um desperdício de um grande volume de madeira utilizado nas fôrmas.

Como pôde se ver, a casa também requisitou uma manutenção muito freqüente e de alto custo, pelo menos até a colocação da manta termoplástica.

No entanto, ainda em 1975, Acayaba realizou o projeto da casa sede de uma fazenda, a Fazenda Pindorama. Nesse projeto também utilizou abóbadas como cobertura, porém o sistema construtivo adotado foi outro (ver capítulo $5)$.

\footnotetext{
${ }^{4}$ Autocrítica feita pelo arquiteto em sua tese de doutorado ACAYABA, 2004.
} 


\section{Capítulo 4}

Residência Milan

\subsection{Ficha técnica - Residência Milan}

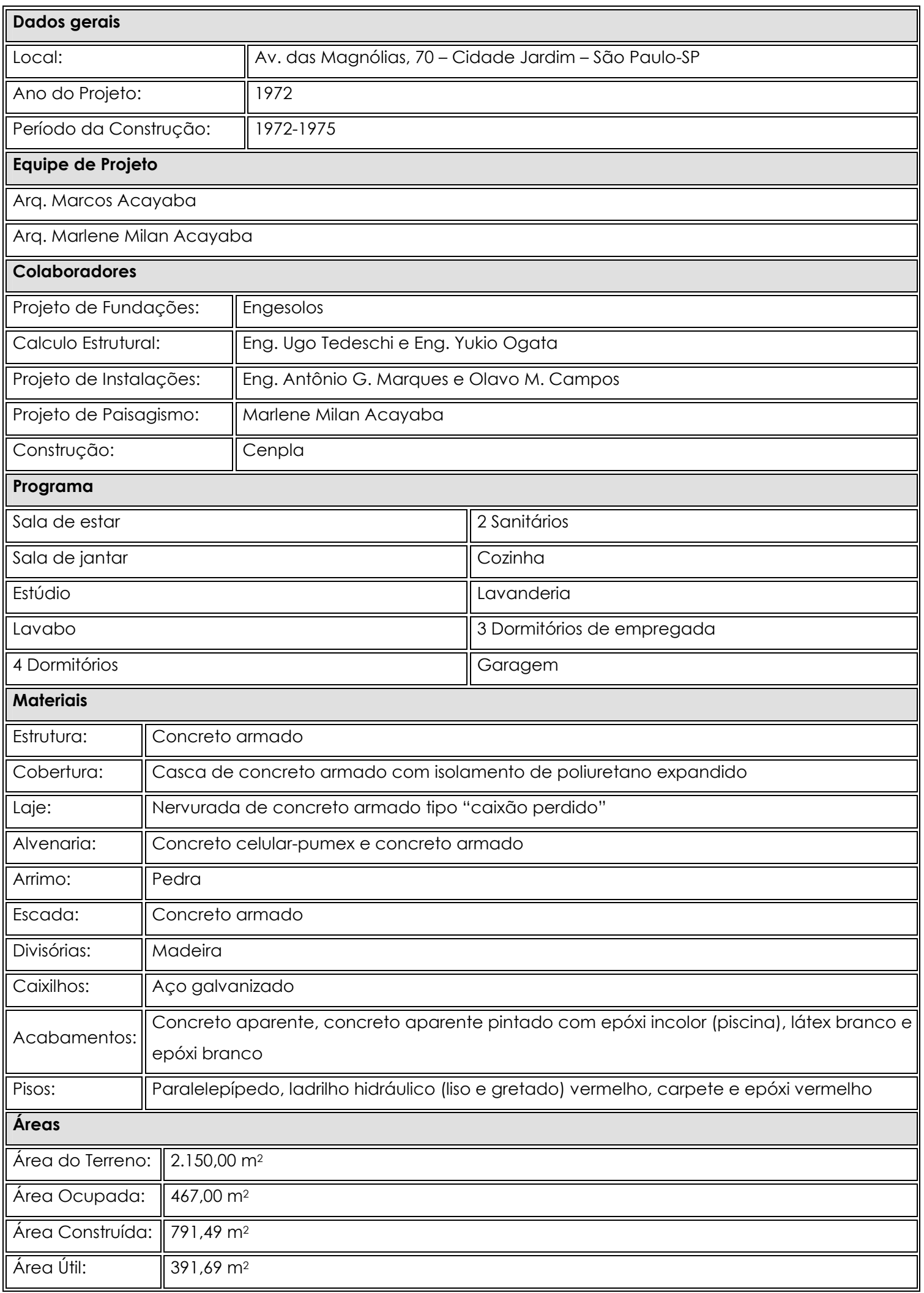




\section{CAPÍTULO 5:}

FAZENDA PINDORAMA: CASA-SEDE E PAVILHÃO

(Cabreúva - SP, 1974 e 1984)

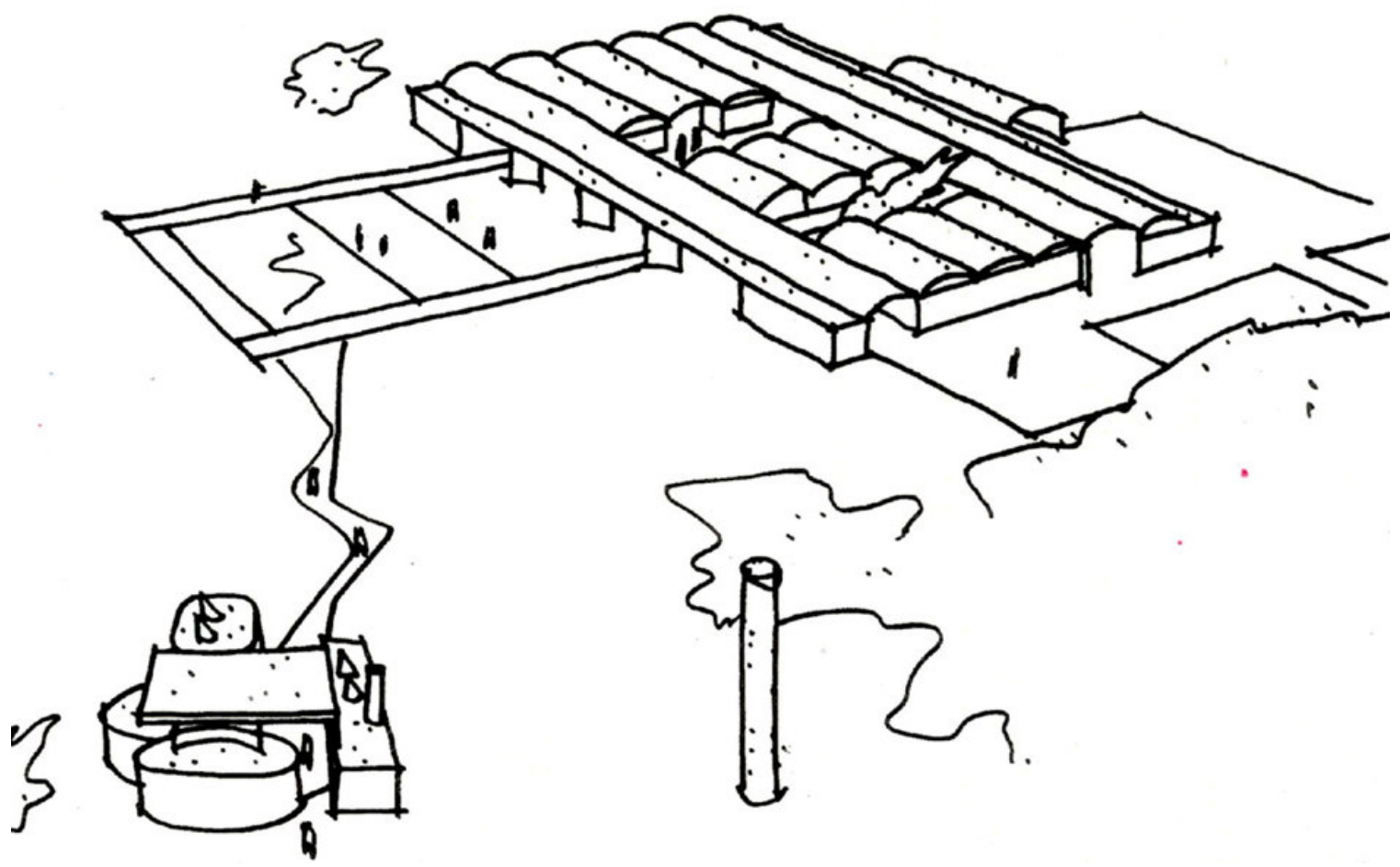

Fig. 5.1: Croqui de Marcos Acayaba. Pavilhão, a baixo, e sede acima. (fonte: arquivo pessoal Marcos Acayabal 


\section{Capítulo 5}

Fazenda Pindorama: Casa-sede e Pavilhão

\subsection{O projeto}

\section{Casa-sede}

A Fazenda Pindorama, localizada em Cabreúva, interior de São Paulo, possui um conjunto de três edificações. A primeira foi o haras, construído em 1969 por Acayaba em parceria com os arquitetos Augusto Malzoni e Cristina Pisa. Em 1974 construiu-se a casa-sede, em parceria também com Malzoni. Por último, foi feito o Pavilhão, que foi destinado a abrigar a área de lazer coletivo da fazenda.

Para o projeto da casa-sede adotou-se uma implantação térrea, sobre um terreno praticamente plano, totalizando uma área construída de 767,0 m².

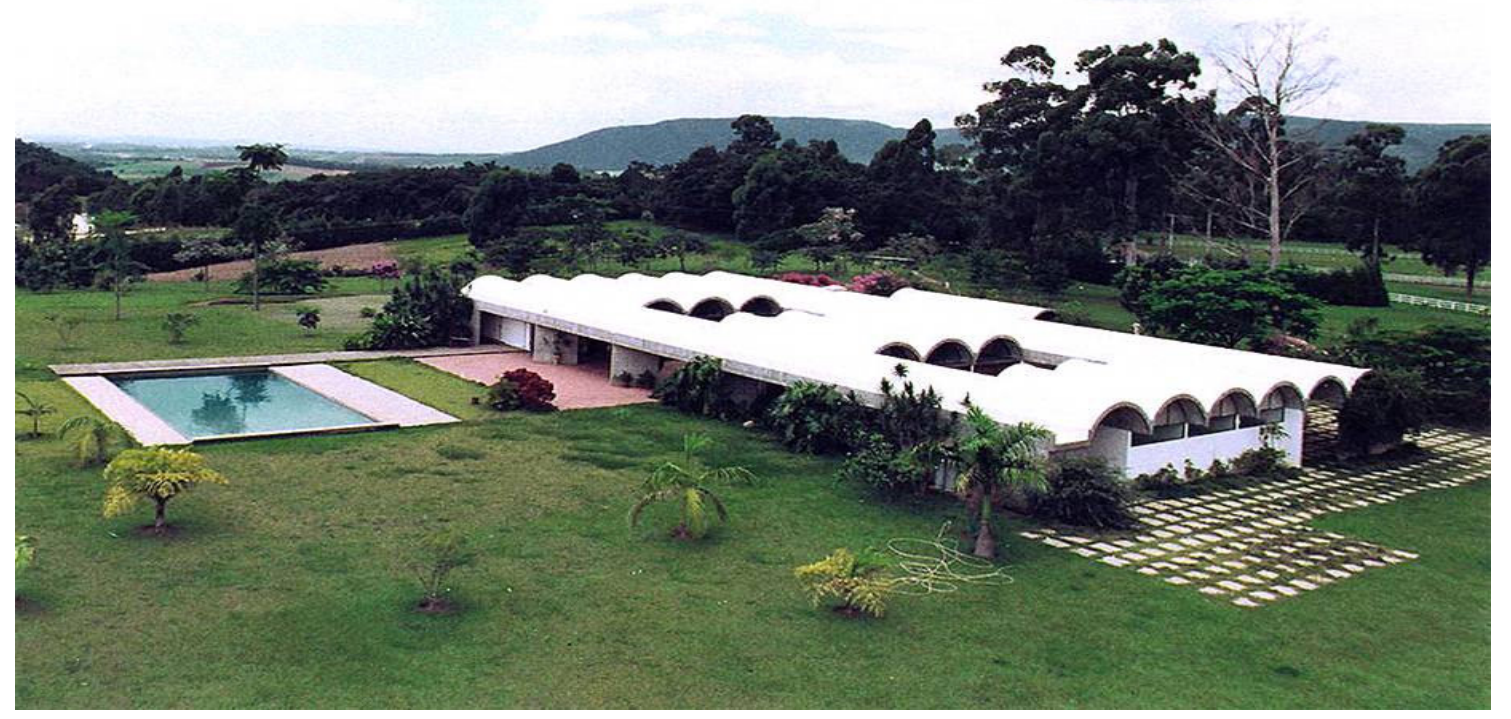

Fig. 5.2: Casa-sede da fazenda. (fonte: MARCOS ACAYABA ARQUITETOS, 2007)

O programa distribui-se em torno de dois pátios internos que conformam áreas descobertas, mas protegidas dos ventos fortes e constantes do local (ACAYABA, 2004). 
Capítulo 5

Fazenda Pindorama: Casa-sede e Pavilhão

Os quartos localizam-se voltados para a fachada leste, para receber o sol da manhã. Ao redor dos pátios são conformadas áreas cobertas que protegem a circulação entre os ambientes.

Num bloco separado, próximo à cozinha, localizam-se as dependências de empregados, a lavanderia e o depósito.

Ao centro, as áreas de uso coletivo: sala de estar, sala de jantar e terraços.

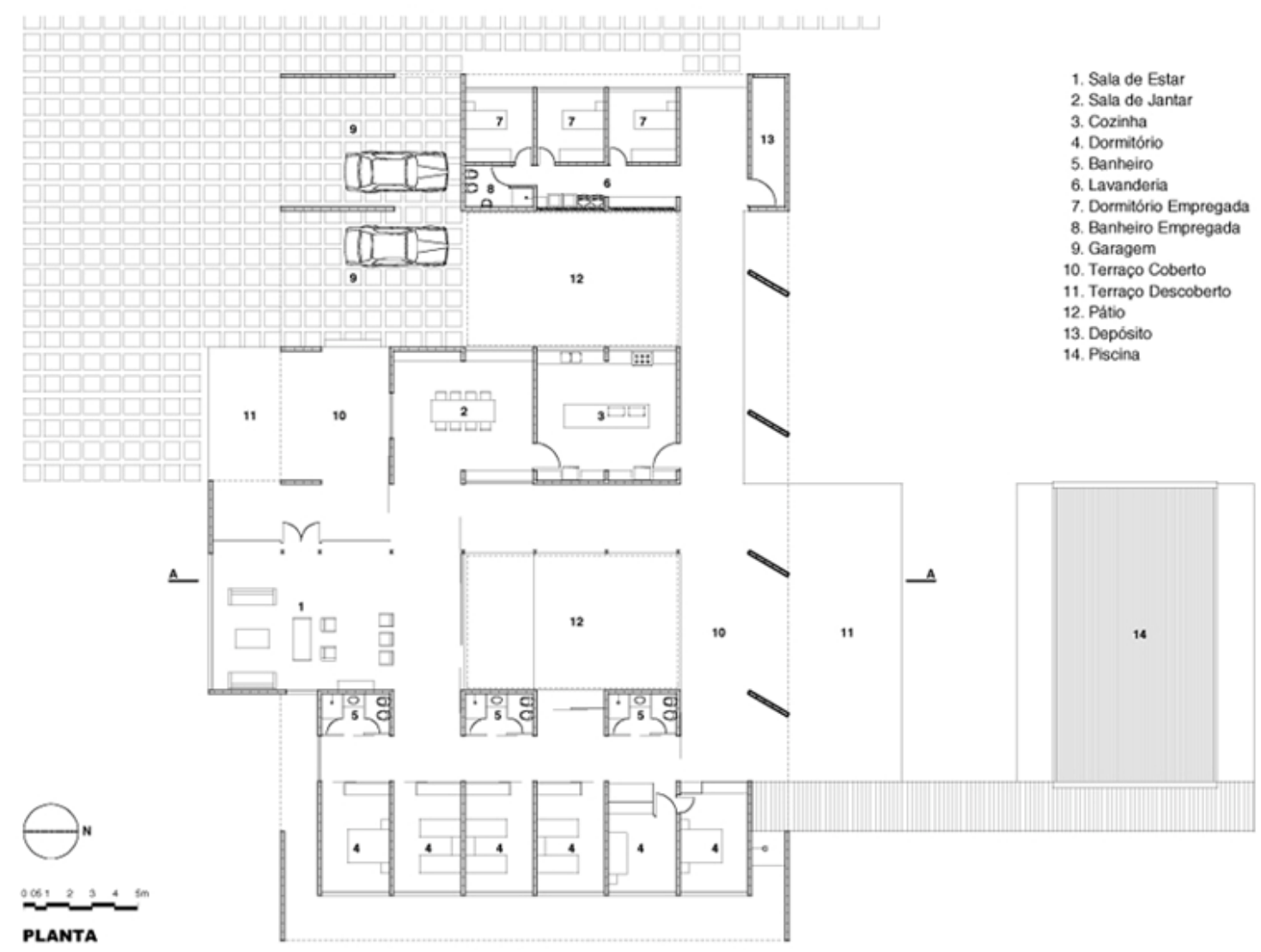

Fig. 5.3: Planta. (fonte: MARCOS ACAYABA ARQUITETOS, 2007)

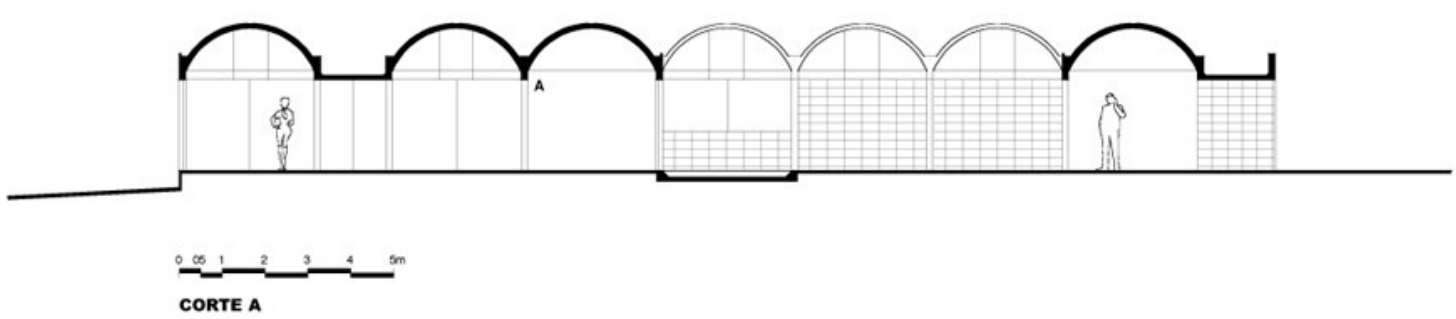

Fig. 5.4: Corte. (fonte: MARCOS ACAYABA ARQUITETOS, 2007) 


\section{Capítulo 5}

Fazenda Pindorama: Casa-sede e Pavilhão

Segundo Acayaba (2004), a cobertura da casa, que combina uma seqüência de abóbadas e pequenas lajes planas nas laterais, adquiriu sua forma definitiva quando, no desenvolvimento do projeto, Malzoni mostrou a ele uma revista que continha uma obra de Louis Kahn, o Kimbell Art Museum, no Texas.

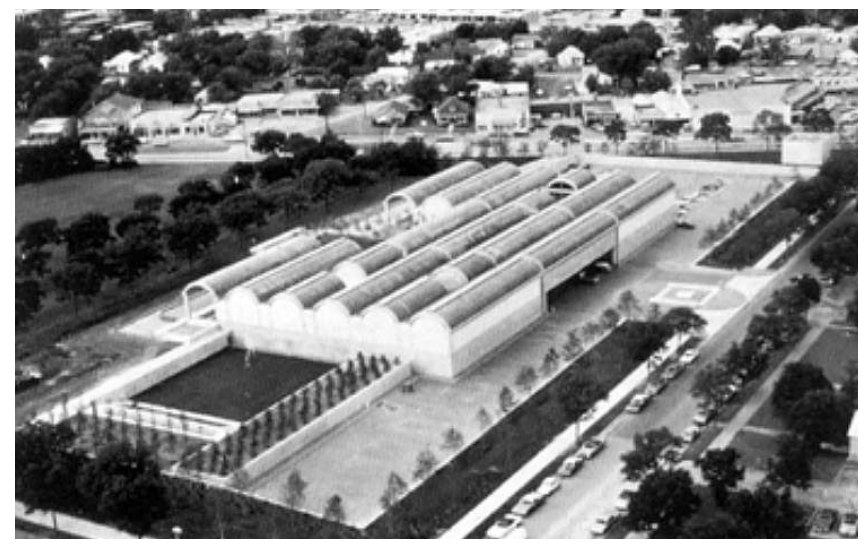

Fig. 5.5: Kimbell Art Museum, de Louis Kahn, principal referência.

A partir de então, o detalhamento construtivo da casa-sede começou a ser feito. Adotou-se um sistema parecido com o que Sérgio Ferro vinha desenvolvendo, mas que utiliza blocos de concreto ao invés de tijolos. Veja análise desse sistema no item 5.3. 


\section{Capítulo 5}

Fazenda Pindorama: Casa-sede e Pavilhão

\subsection{A solução construtiva}

\section{Abóbadas de blocos de concreto}

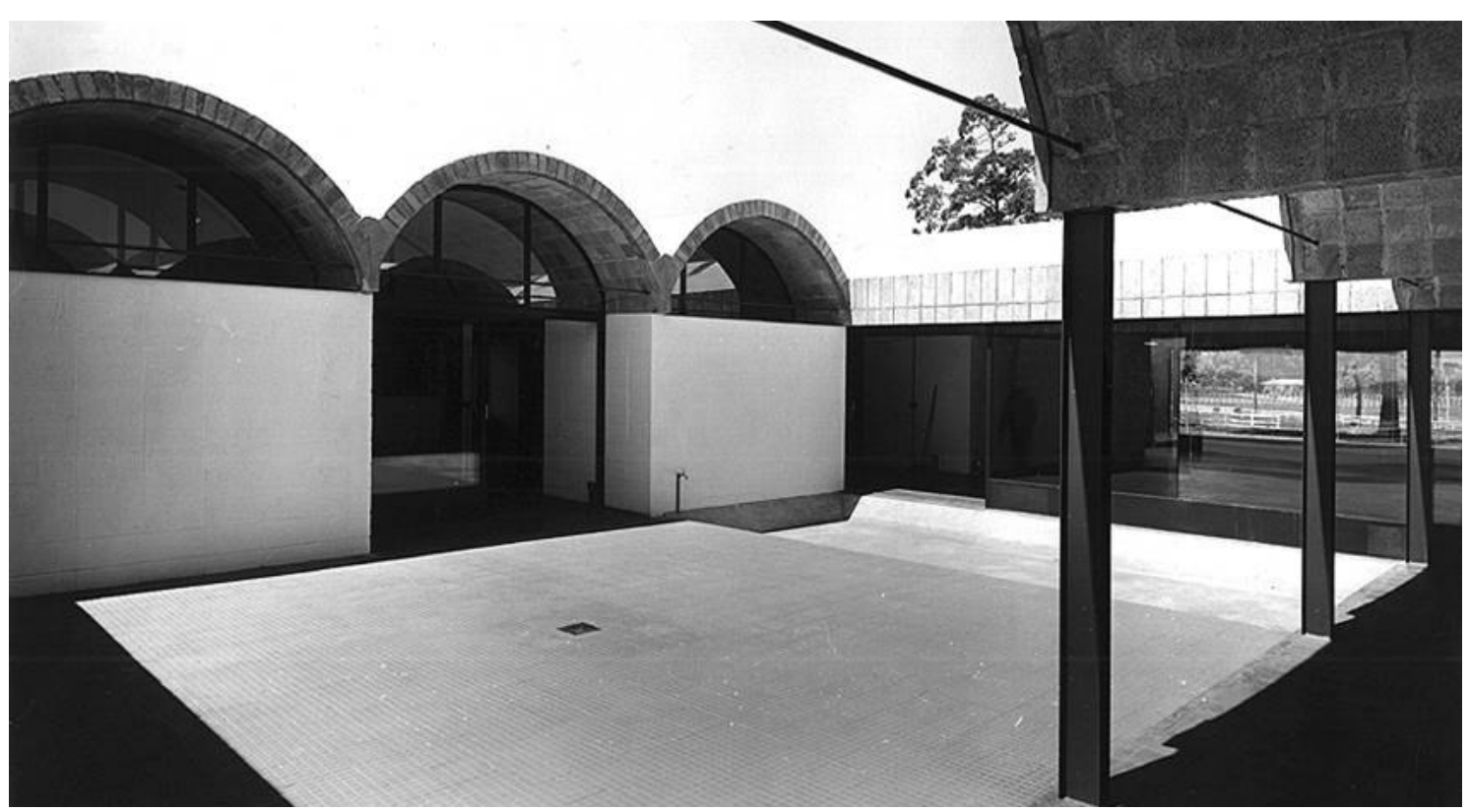

Fig. 5.6: Casa-sede fazenda Pindorama. Pátio central. (fonte: MARCOS ACAYABA ARQUITETOS, 2007)

No período de construção da casa-sede da fazenda Pindorama diversos arquitetos brasileiros estavam trabalhando com coberturas em abóbada. Alguns, como Niemeyer, utilizando o concreto armado como material de construção, e outros, como Sérgio Ferro e Carlos Milan, o tijolo cerâmico.

Para o projeto desta casa, foram utilizados blocos de concreto, tanto nas abóbadas de cobertura quanto nas vedações.

O processo de construção das abóbadas, cuja largura é de 3,0 m, inicia-se com a colocação de cambotas de madeira, a cada 1,50 m e travadas duas a duas, sobre guias horizontais. Após serem niveladas por cunhas, nelas são pregadas ripas a cada $20,0 \mathrm{~cm}$ no sentido longitudinal das abóbadas. Começa-se então o assentamento dos blocos, de $20,0 \times 20,0 \times 7,0 \mathrm{~cm}$, em fiadas alternadas com lajotas de $2,0 \mathrm{~cm}$ de espessura, formando 'canaletas', nas quais se coloca a armadura: ferros de 3/16". Em seguida, se faz o 


\section{Capítulo 5}

Fazenda Pindorama: Casa-sede e Pavilhão

capeamento de $3,5 \mathrm{~cm}$ de concreto, preenchendo as canaletas e dando o acabamento nas abóbadas. Após a cura do concreto, as cambotas e guias são retiradas e reaproveitadas na construção de outros trechos. Segundo Acayaba (2004), foram cerca de $100 \mathrm{~m}^{2}$ de fôrma para $800 \mathrm{~m}^{2}$ de cobertura.

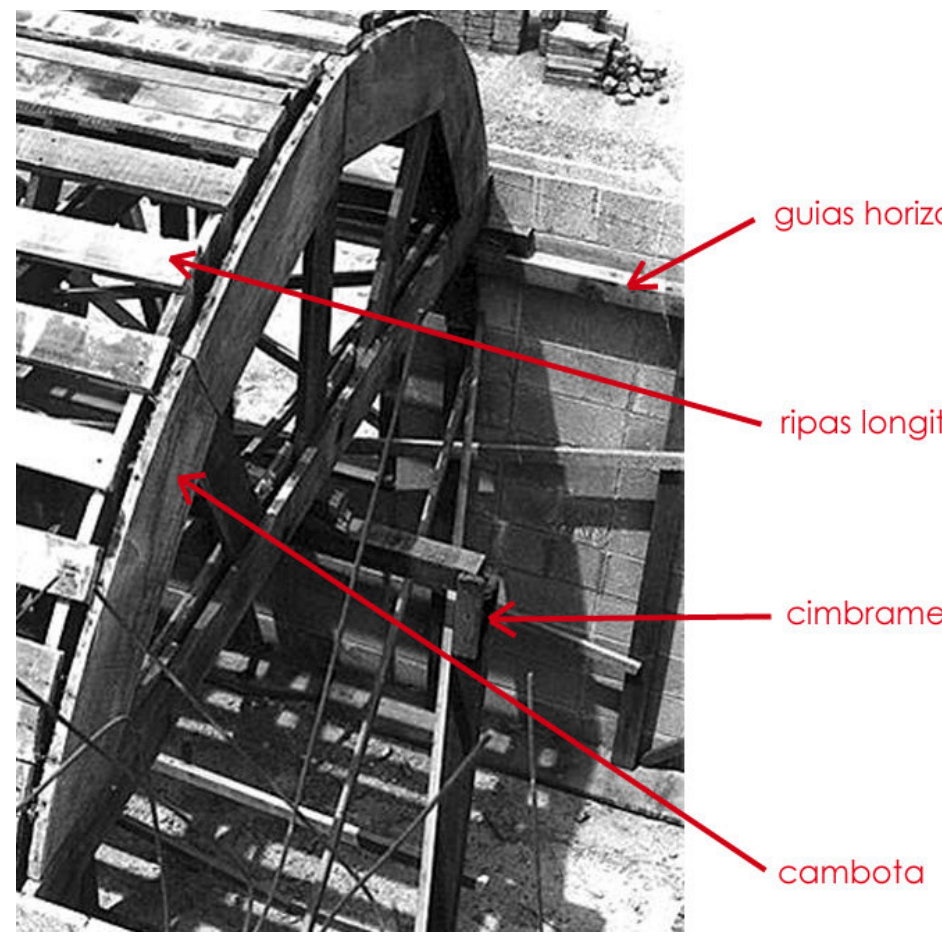

Fig. 5.7: Montagem da fôrma de madeira.

(fonte: MARCOS ACAYABA ARQUITETOS, 2007)

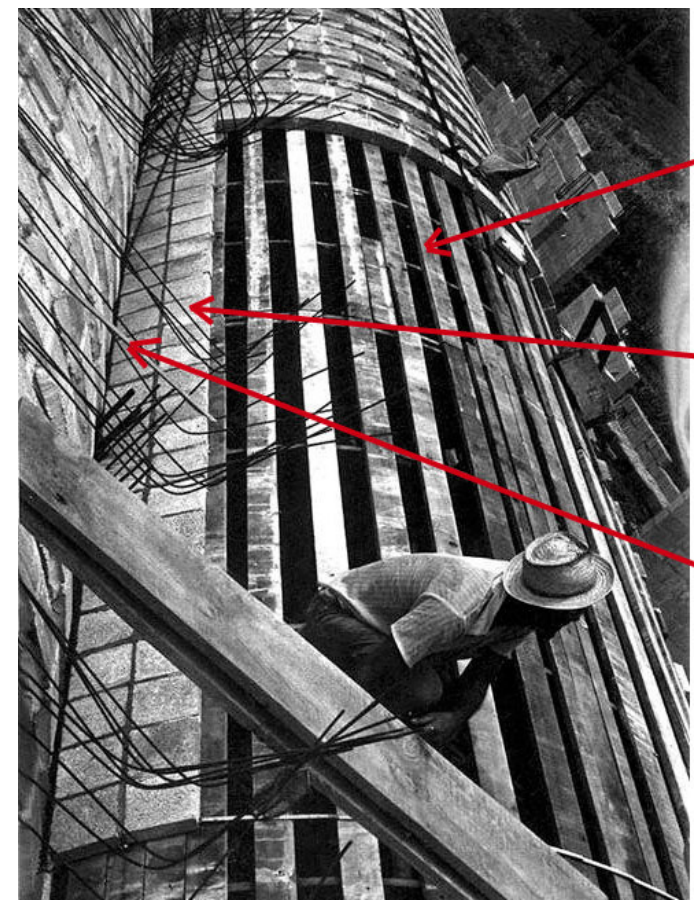

Fig. 5.8: Início da colocação dos blocos. (fonte: MARCOS ACAYABA ARQUITETOS, 2007) 
Capítulo 5

Fazenda Pindorama: Casa-sede e Pavilhão

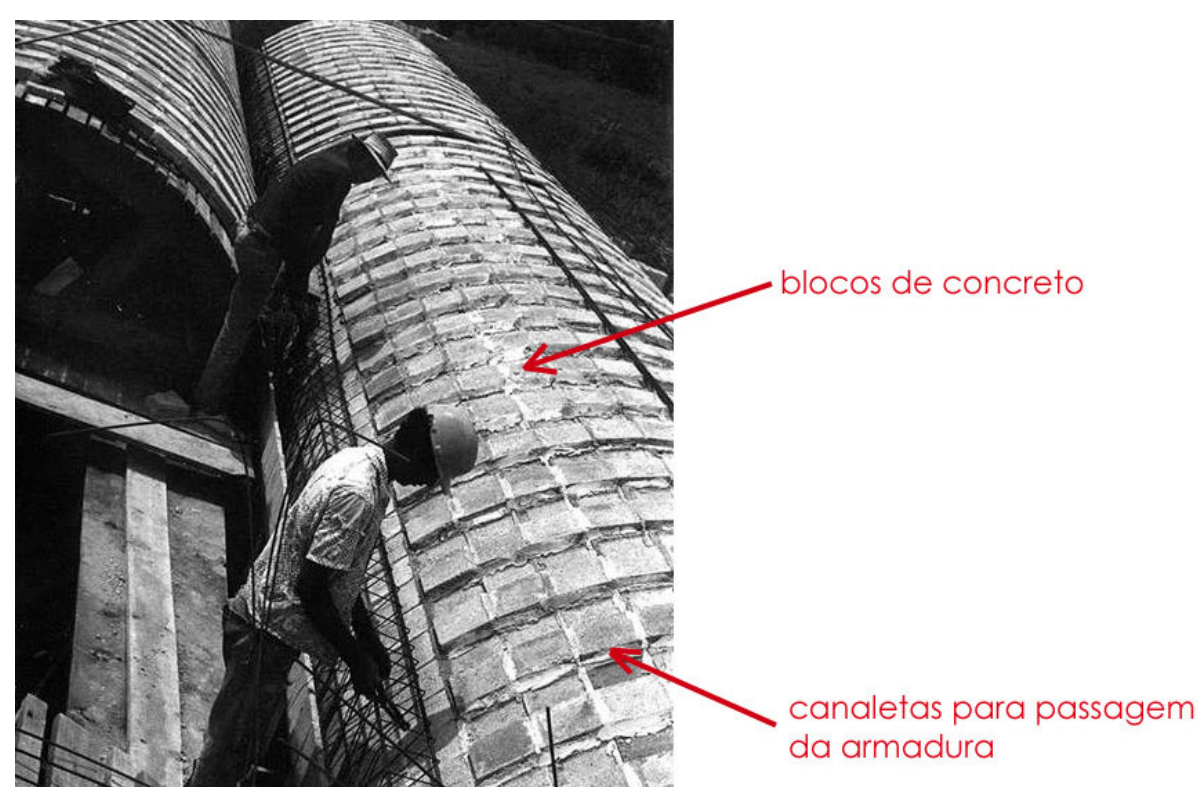

Fig. 5.9: Início da colocação da armadura. (fonte: MARCOS ACAYABA ARQUITETOS, 2007)

Entre as abóbadas, blocos-verga em ' $U$ ' e lajotas de $3,0 \mathrm{~cm}$ de espessura formam um conjunto rígido, que vence vãos de até $6,0 \mathrm{~m}$ ou balanços de até 2,0 m de comprimento.

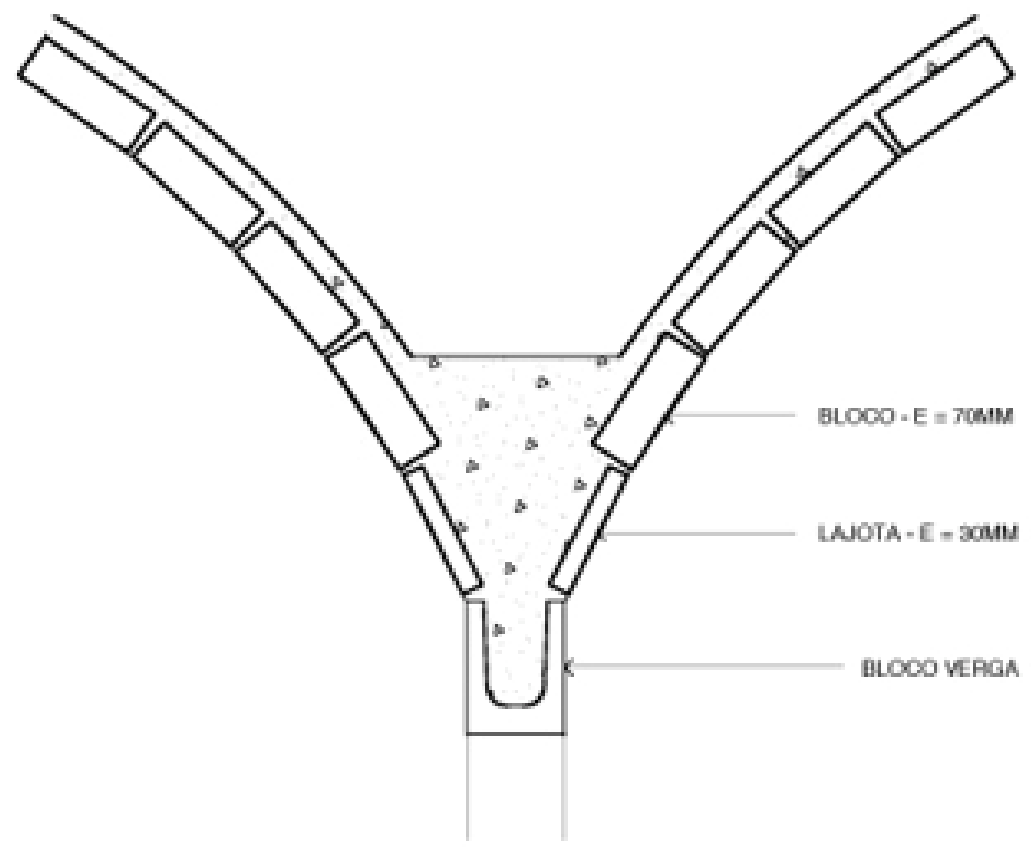

Fig. 5.10: Detalhe entre abóbadas.

(fonte: MARCOS ARQUITETOS, 2007) 


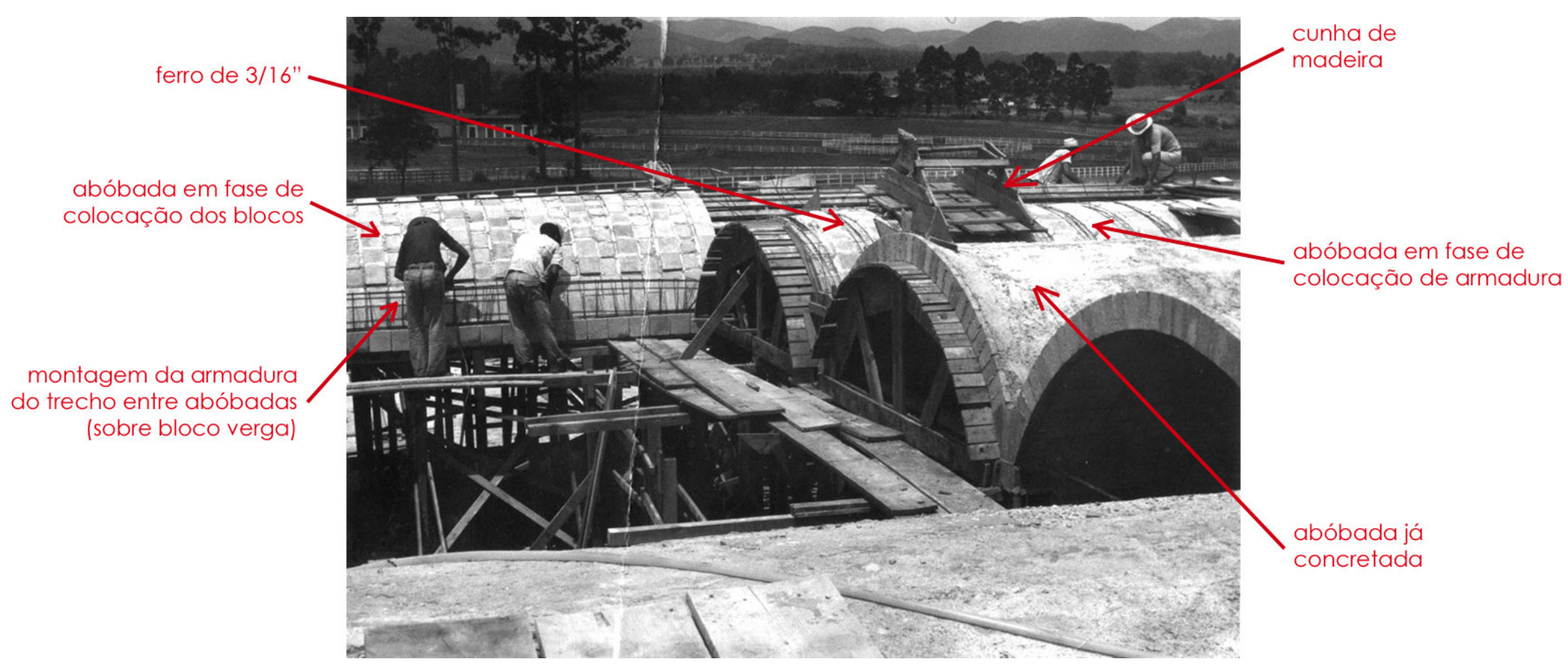

Fig. 5.11: Abóbadas são construídas em etapas seqüenciais em função umas das outras. (fonte: MARCOS ACAYABA ARQUITETOS, 2007) 


\section{Capítulo 5}

Fazenda Pindorama: Casa-sede e Pavilhão

A disposição das abóbadas, enfileiradas em série, teoricamente, faria com que elas 'segurem' umas às outras no sentido horizontal, controlando as forças resultantes do seu peso próprio, mas ao fim da seqüência, a força de tração resultaria muito forte, por isso, foram colocados tirantes de aço que tracionam a base de cada uma delas em seu sentido transversal.
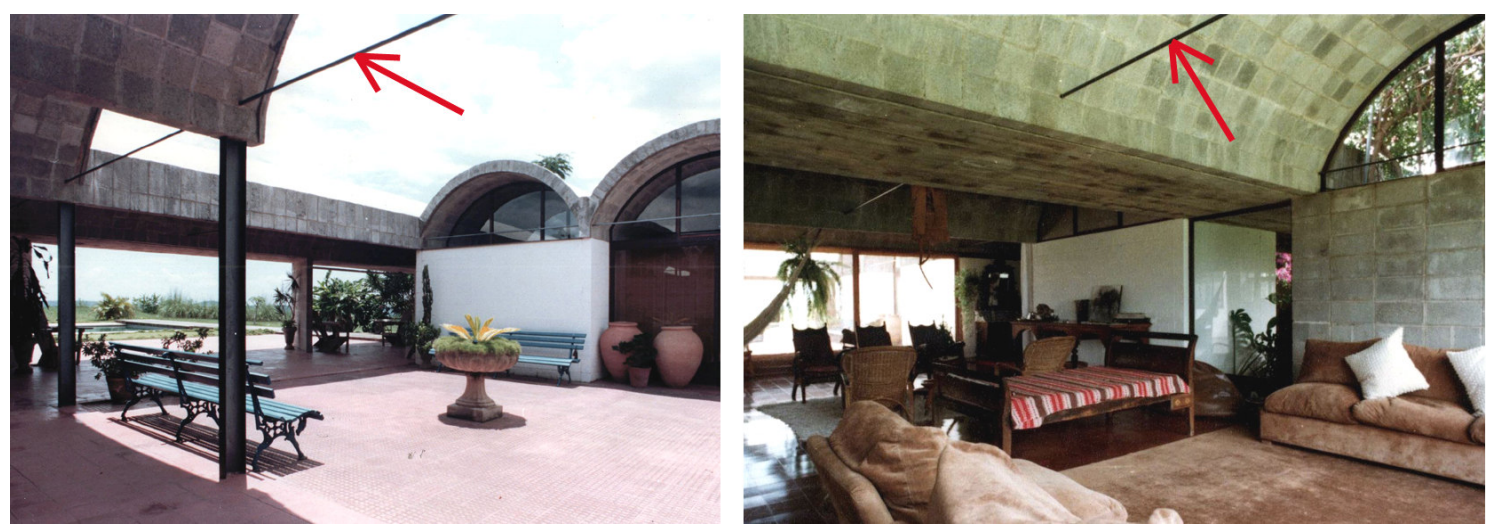

Fig. 5.12: Tirantes de aço tracionam as bases da abóbadas.

(fo fonte: MARCOS ACAYABA ARQUITETOS, 2007 - editada pela autora)

Essas forças ocorrem porque, segundo Lopes (2006), "[...] o arco pleno, derivado de uma semicircunferência, promove uma dissimetria entre esforços de tração e compressão [...]".

Lopes (2006) ainda explica que os romanos, na construção de arcos e abóbadas, acrescentavam massa e consequentemente peso, ao seu redor, na intenção de conter os esforços que poderiam levar ao colapso da estrutura.
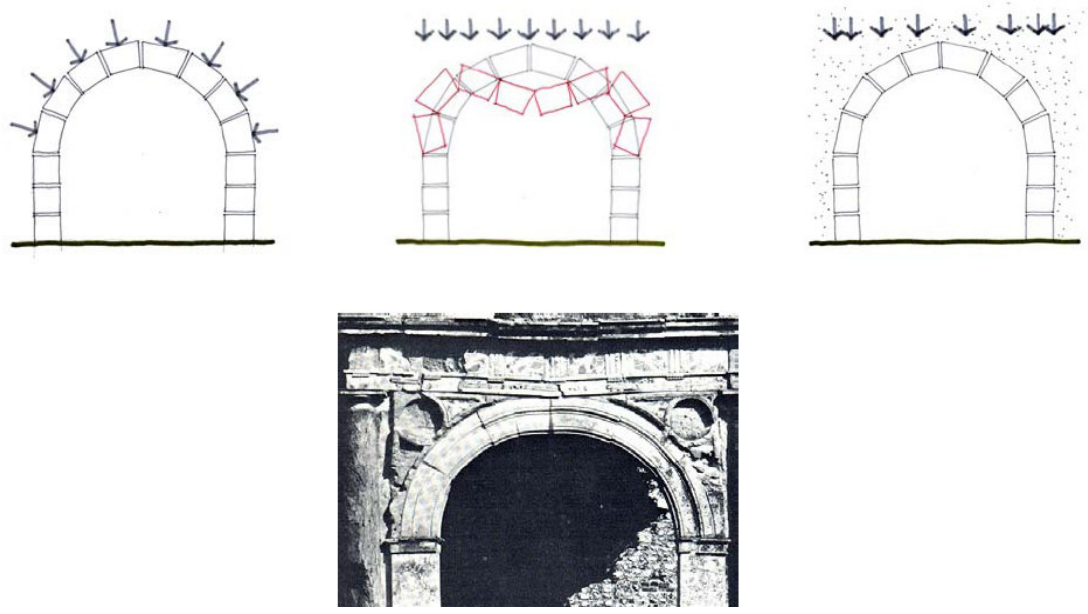

Fig. 5.13: Esquema de forças em arcos/abóbadas e solução de arco romano. (fonte: LOPES, 2006, p. 166) 
Capítulo 5

Fazenda Pindorama: Casa-sede e Pavilhão
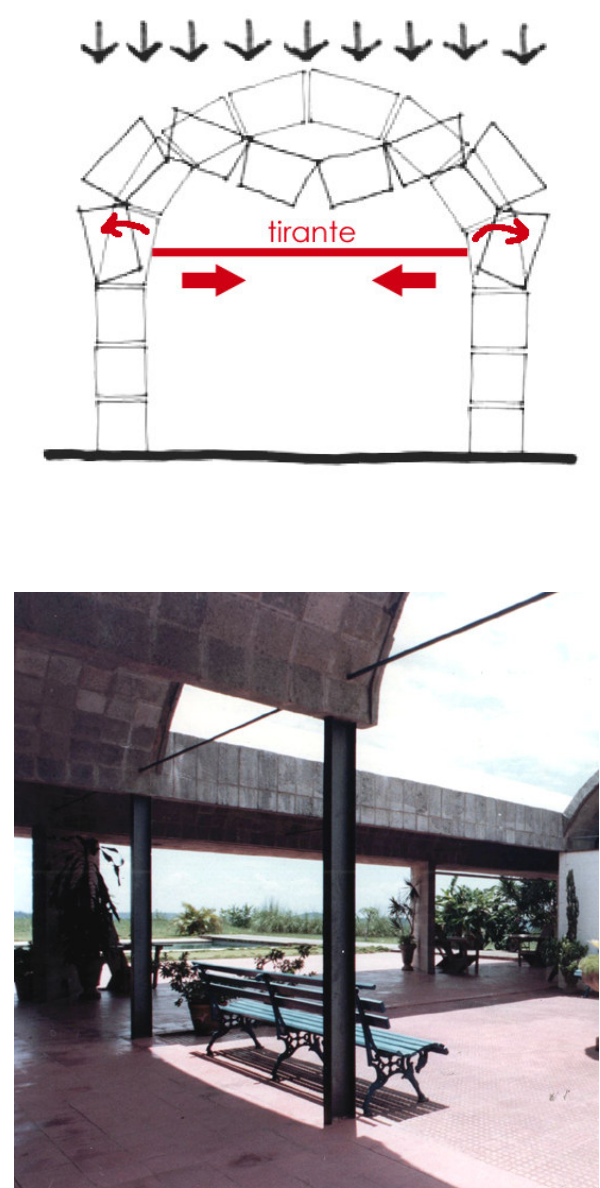

Fig. 5.14: Esquema de forças. Tirante impede flexão das peças de base, evitando colapso da estrutura.

(fonte: LOPES, 2006, p. 166 - editada pela autora)

Fig. 5.15: Em alguns pontos, a cobertura apóia-se em pilares de aço de perfil $I$.

(fonte: MARCOS ACAYABA ARQUITETOS, 2007) 


\section{Capítulo 5}

Fazenda Pindorama: Casa-sede e Pavilhão

\subsection{O projeto}

\section{Pavilhão Pindorama}

O projeto do pavilhão iniciou-se dez anos após a casa, em 1984. Segundo Acayaba (2004), a idéia era utilizar uma linguagem lúdica, de formas simples e cores primárias, que abrigasse todas as funções de acordo com suas especificidades.

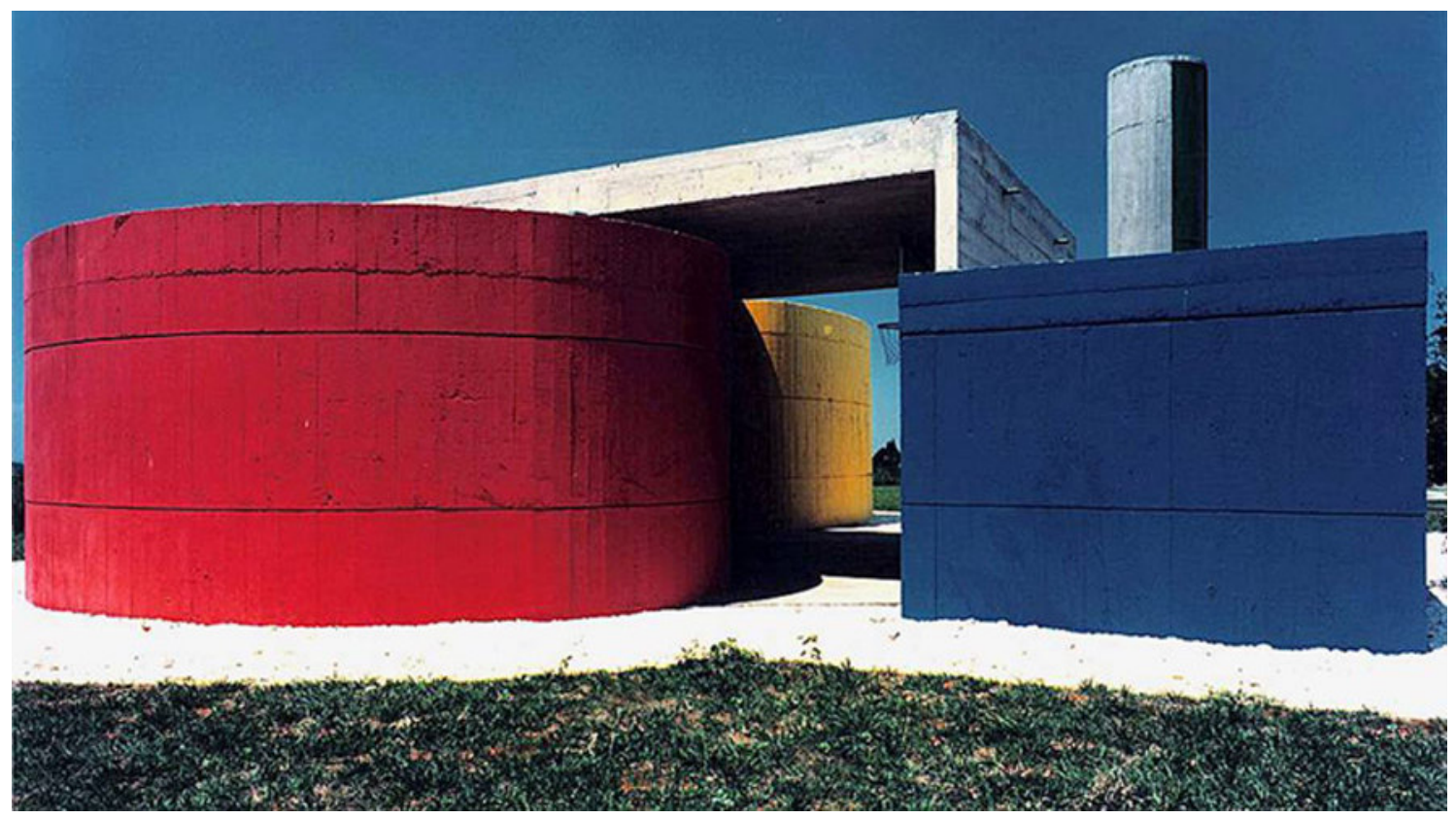

Fig. 5.16: Pavilhão Pindorama. (fonte: MARCOS ACAYABA ARQUITETOS, 2007)

No desenvolvimento do projeto, Acayaba realizou estudos com um modelo físico em escala. Reproduziu os volumes em 1:100, com cartolina e os pintou com guache.

Cada um deles corresponderia a uma função: o da sala de snooker, amarelo, com planta em super-elipse de retângulo e pé-direito alto, para manuseio dos tacos; o da sala de vídeo e som, vermelho, com planta em elipse e pé-direito mais baixo; o das saunas, azul, com planta retangular; e o da sala de carteado, de elementos vazados em concreto aparente com vidros e planta em forma de parábola. 


\section{Capítulo 5}

Fazenda Pindorama: Casa-sede e Pavilhão

Ao centro, configura-se um pátio coberto por uma laje plana, que abriga mesa de ping-pong e cesta de basquete e é protegido dos ventos do sul pelo volume das saunas.

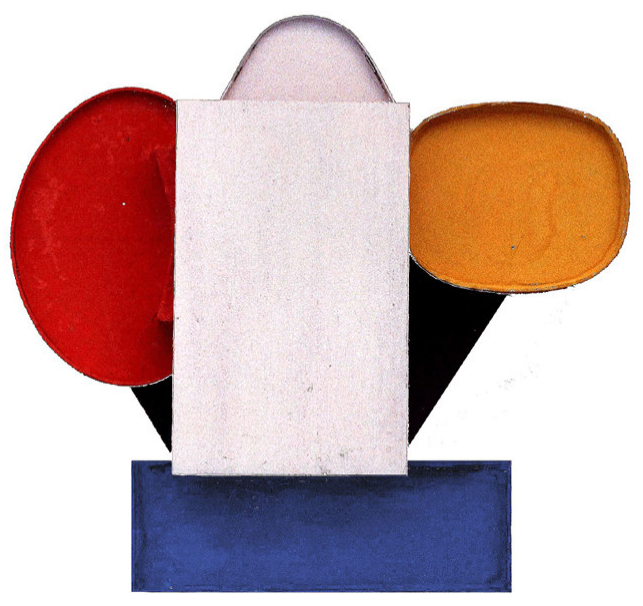

Fig. 5.17: Maquete em cartolina feita pelo arquiteto para estudo de projeto.

(fonte: MARCOS ACAYABA ARQUITETOS, 2007)

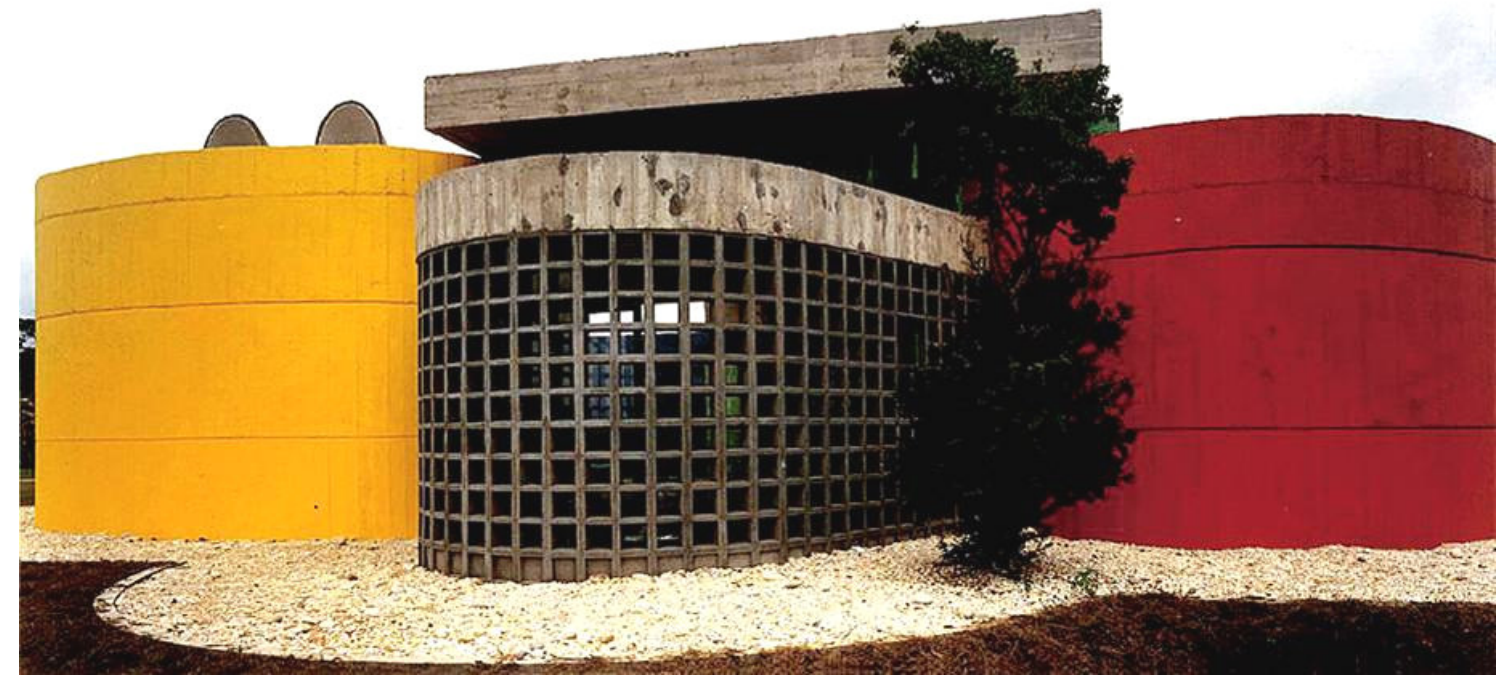

Fig. 5.18: Vista geral; face norte. (fonte: MARCOS ACAYABA ARQUITETOS, 2007) 
Capítulo 5

Fazenda Pindorama: Casa-sede e Pavilhão

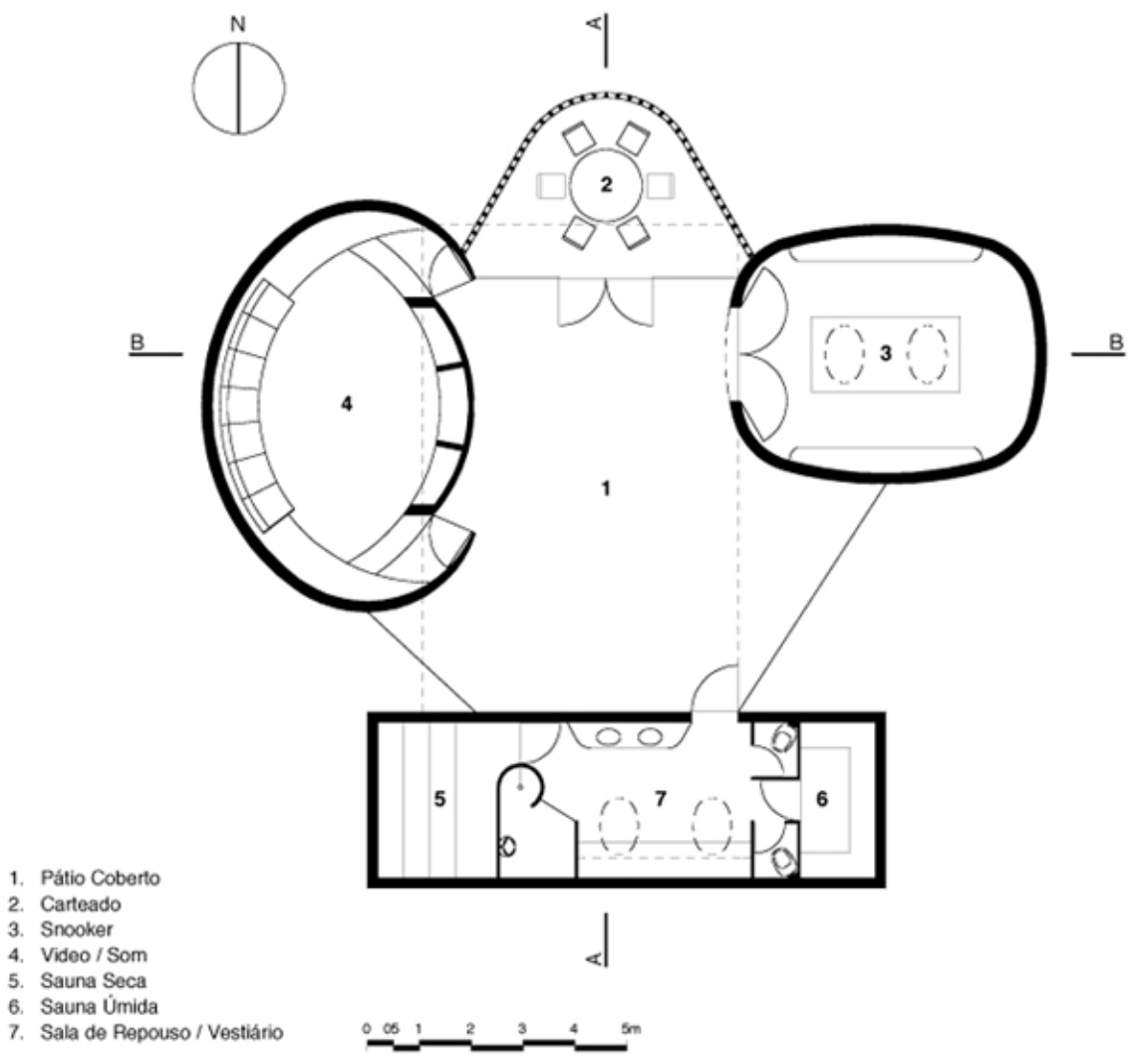

Fig. 5.19: Planta baixa. (fonte: MARCOS ACAYABA ARQUITETOS, 2007)
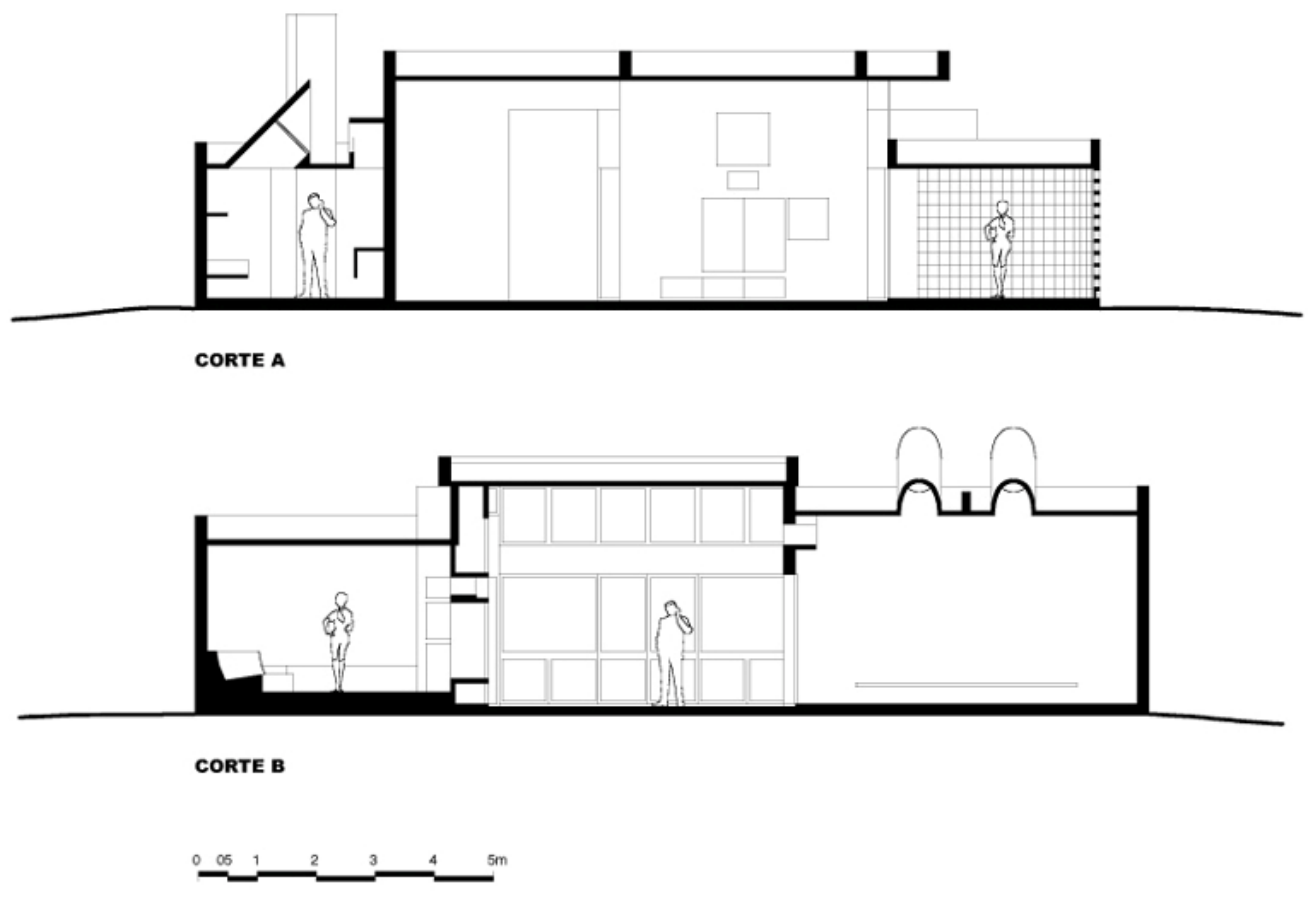

Fig. 5.20: Cortes. (fonte: MARCOS ACAYABA ARQUITETOS, 2007) 


\section{Capítulo 5}

Fazenda Pindorama: Casa-sede e Pavilhão

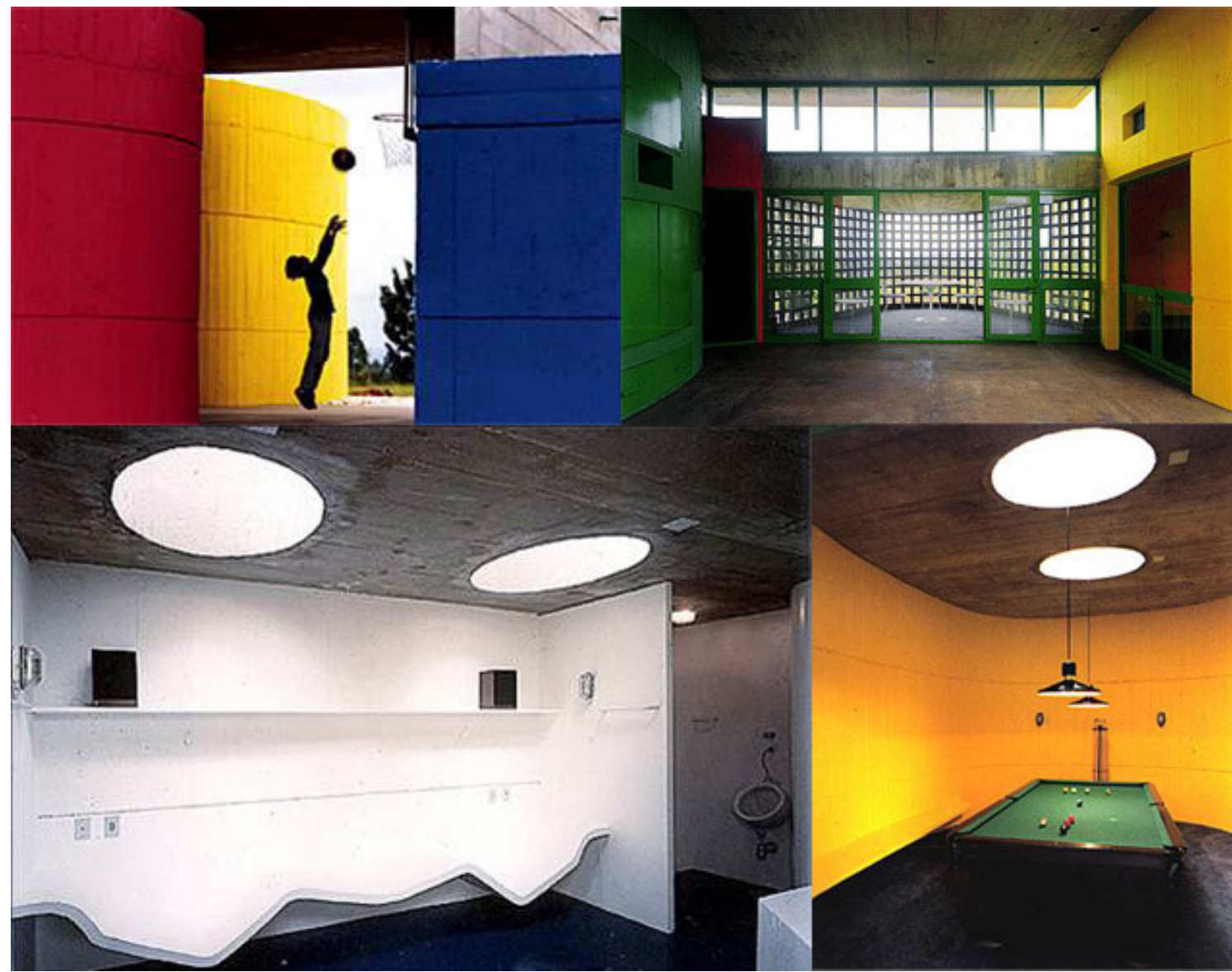

Fig. 5.21: Pátio central. Sala de carteado. Sauna. Sala de snooker. (fonte: MARCOS ACAYABA ARQUITETOS, 2007)

Acayaba (2004) nesse projeto faz referência a Le Cobusier, mais precisamente, ao projeto do Convento em La Tourette, na utilização de volumes de formas puras pintados nas cores primárias e dos cannons de lumière para iluminação dos espaços fechados.

No entanto, diferentemente do convento, que é construído em concreto armado, o Pavilhão adota um sistema misto. As paredes possuem enchimento de tijolos cerâmicos com uma capa de concreto nas faces interna e externa. Veja análise desse sistema no item 5.4.

Foram utilizados elementos vazados em concreto como parede estrutural. A cada duas fiadas de elementos vazados foram colocadas duas bitolas de aço de 3/16", tanto na horizontal quanto na vertical, conferindo à parede curva a capacidade de suportar o peso da laje de cobertura. "Uma parede estrutural 
Capítulo 5

Fazenda Pindorama: Casa-sede e Pavilhão

e luminosa, como nas Usonian Automatic de Frank Lloyd Wright..." (ACAYABA, 2004, v.1, p. 62).

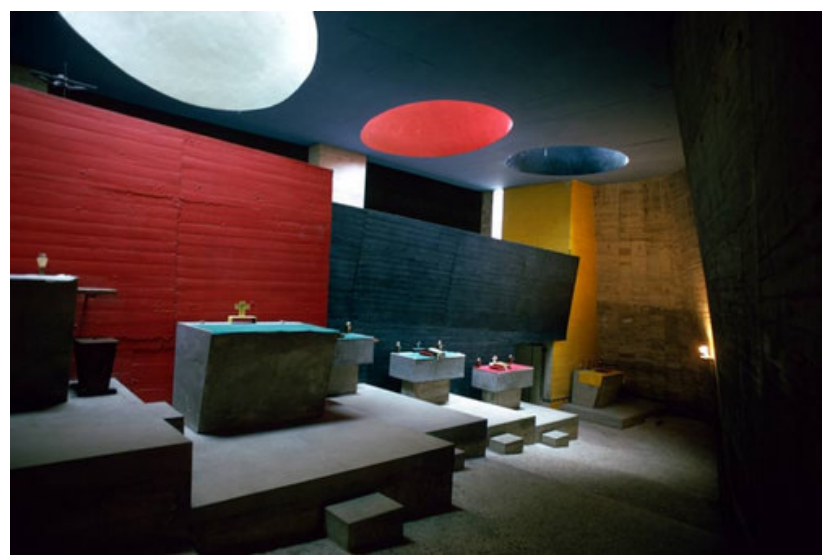

Fig. 5.22: Convento de La Tourette.Le Corbusier. 1953. (fonte: ROSLYN, 2007)

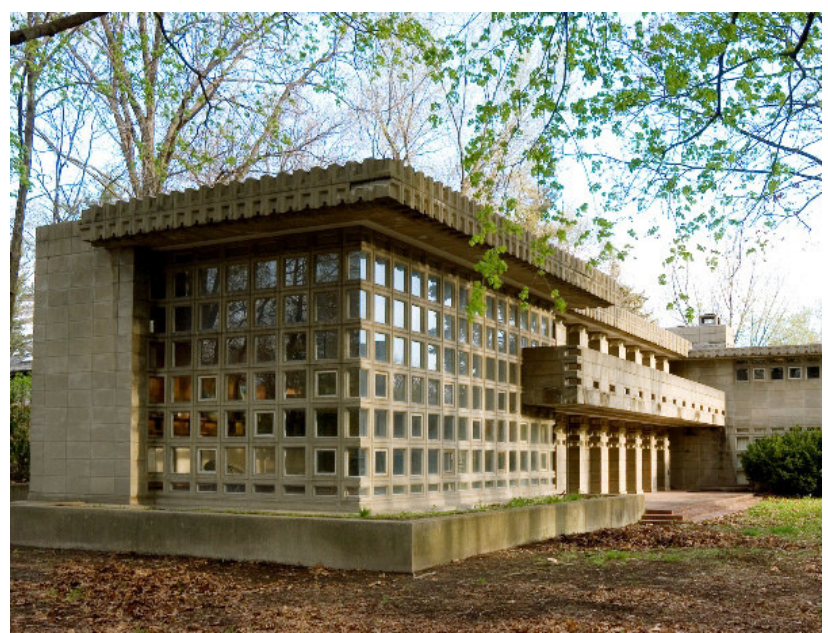

Fig. 5.23: Turkel House. Usonian Automatic. Frank Lloyd Wright. (fonte: MAZZEI, 2005) 


\section{Capítulo 5}

Fazenda Pindorama: Casa-sede e Pavilhão

\subsection{A solução construtiva}

\section{Parede de tijolo e concreto}

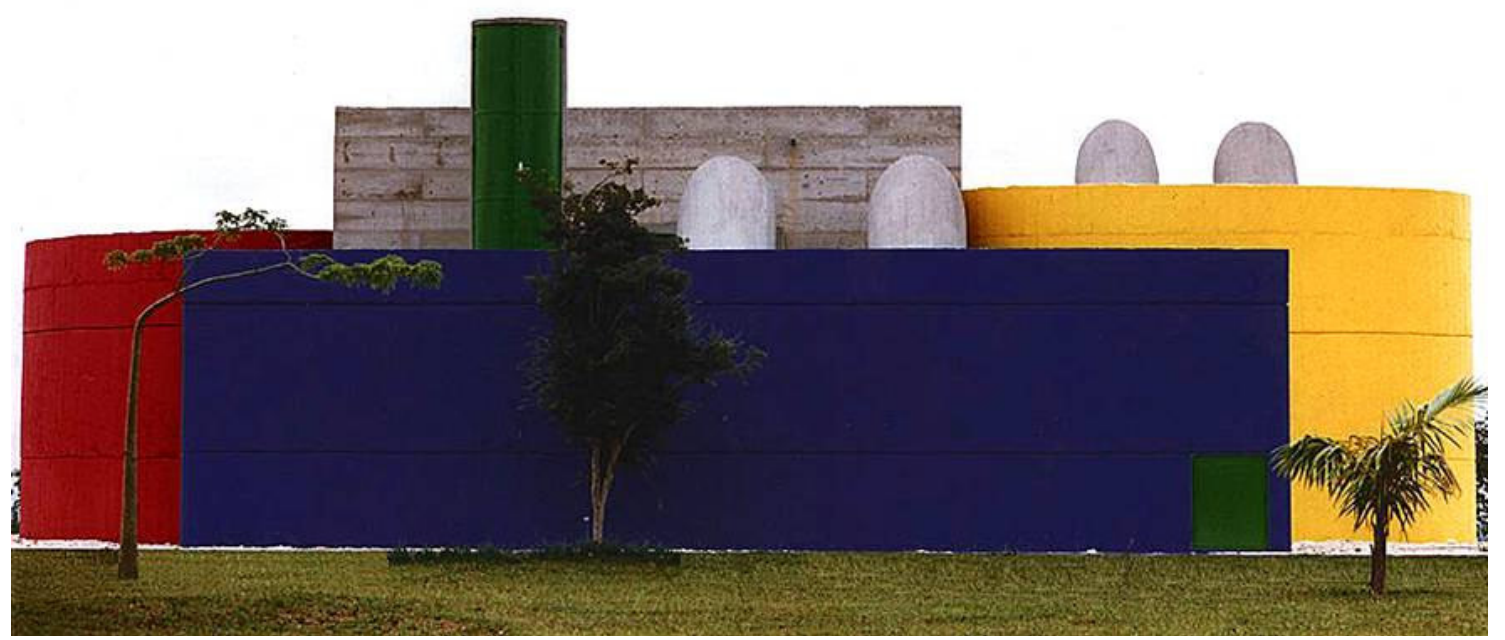

Fig. 5.24: Pavilhão Pindorama, face sul. (fonte: MARCOS ACAYABA ARQUITETOS, 2007)

O Pavilhão Pindorama adota um sistema misto, com o intuito de diminuir o uso do concreto e melhorar o isolamento térmico: as paredes possuem enchimento de tijolos cerâmicos de $10 \mathrm{~cm}$ de largura, com $5 \mathrm{~cm}$ de concreto nas faces interna e externa, numa espessura total de $20 \mathrm{~cm}$.

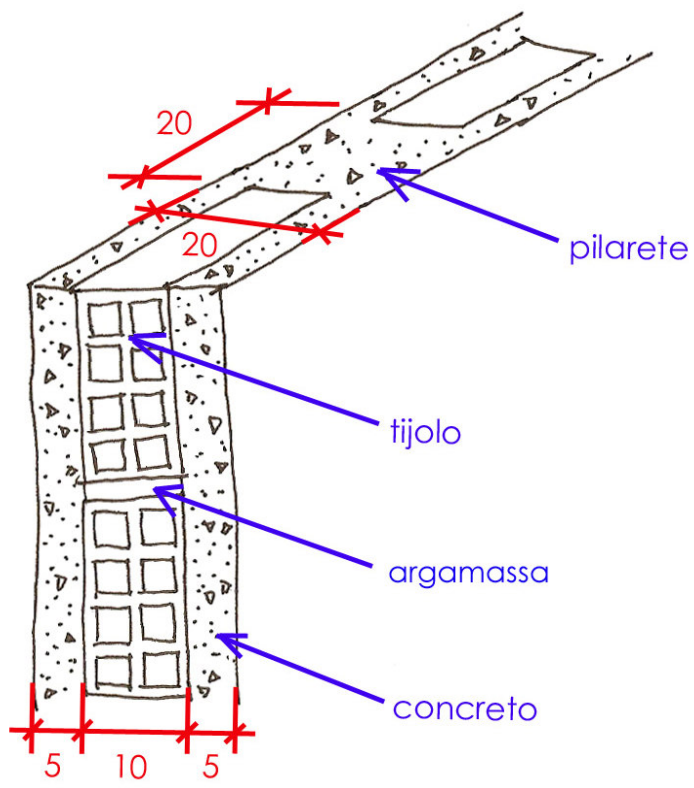

Fig. 5.25: Croqui. Parede em perspectiva. (fonte: autora) 


\section{Capítulo 5}

Fazenda Pindorama: Casa-sede e Pavilhão

A cada metro foi executado um pilarete de $20 \mathrm{~cm} \times 20 \mathrm{~cm}$ e a cada 1,5 $\mathrm{m}$ de altura, uma cinta de amarração. "Uma espécie de nervurada de caixão perdido na horizontal" (ACAYABA, 2004, v.1, p. 61).

A execução da capa de concreto foi realizada em etapas, com reaproveitamento das fôrmas. Cada faixa de concretagem, para evitar o escorrimento, era arrematada com sarrafos trapezoidais, criando vincos horizontais na fachada que mostram as etapas de execução.

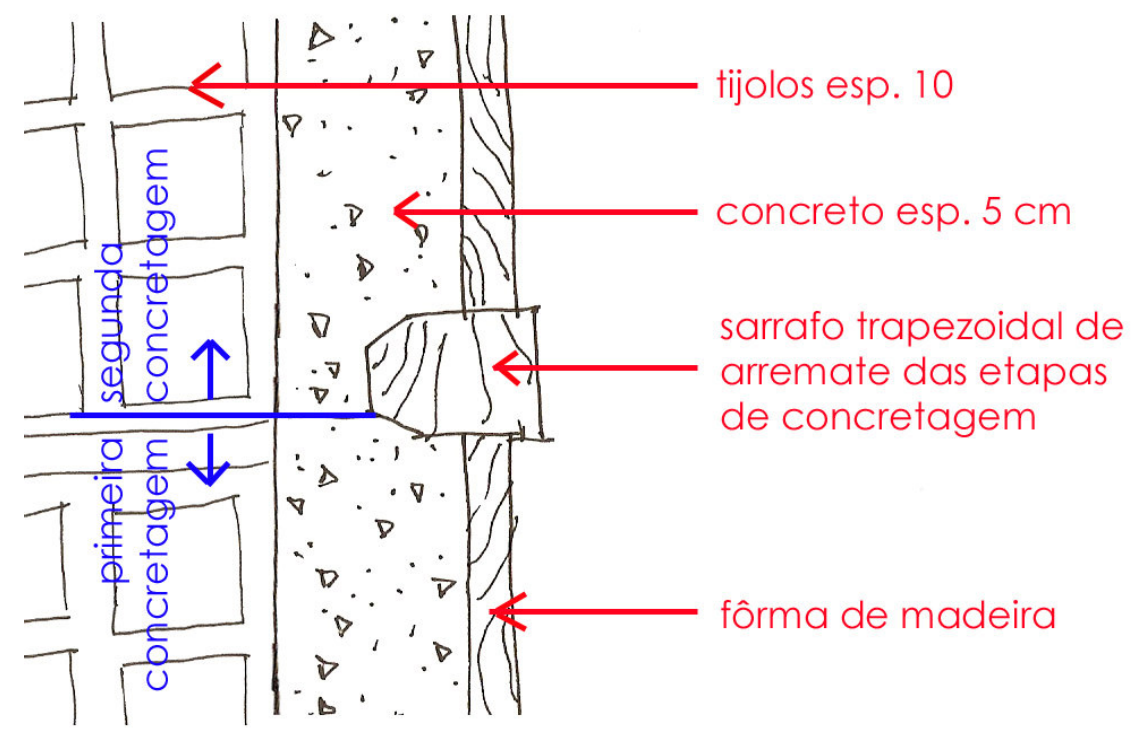

Fig. 5.26: Croqui. Esquema da moldagem da parede em corte. (fonte: autora)

Segundo o arquiteto, essa solução foi adotada em função principalmente do desempenho térmico da edificação.

Uma parede inteira de concreto não teria desempenho térmico bom. Já inserindo no meio uma camada de tijolos furados, devido ao colchão de ar criado em seu interior, sua inércia térmica aumentaria, conferindo à edificação maior conforto.

Para comparar as duas possíveis soluções: 'parede de concreto' e 'parede de concreto e tijolos', aplicou-se, com indicação da Prof. Dra. Rosana Maria Caran, a norma NBR 15220, da Associação Brasileira de Normas Técnicas (ABNT), de Desempenho térmico de edificações, verificando a condutibilidade térmica das duas composições de parede e comparando seus resultados. 


\section{CASO 1: Parede de concreto com tijolos.}

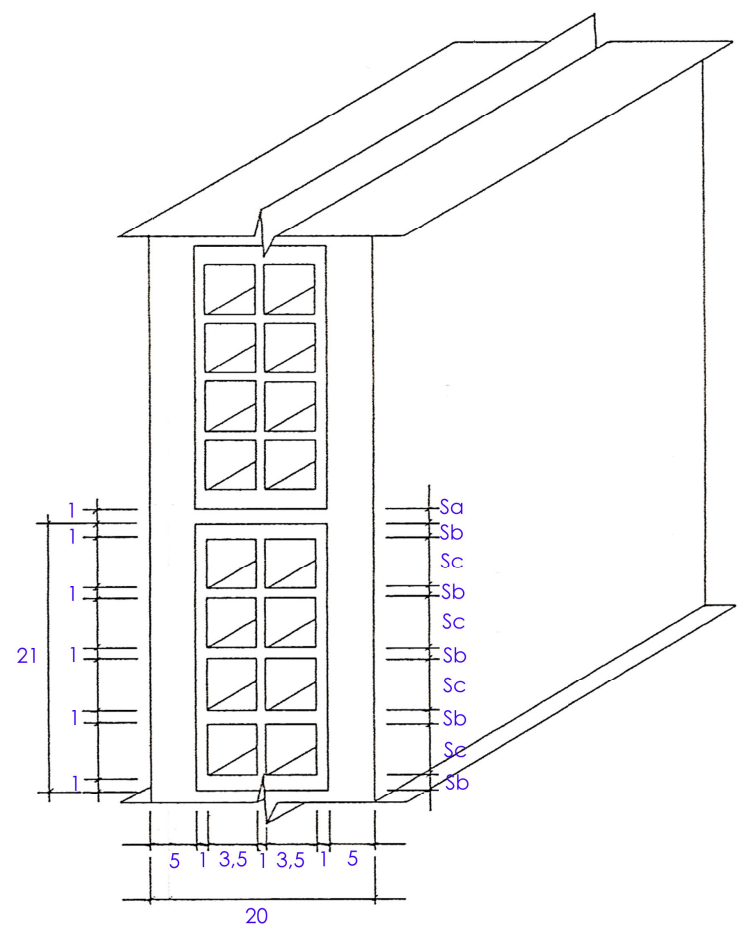

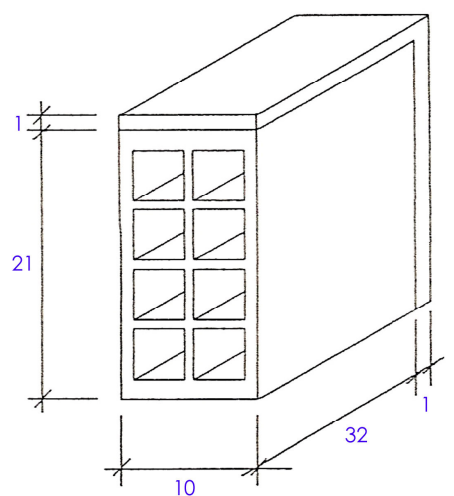

ELEMENTO ISOLADO

PAREDE

Fig. 5.27: Vista em perspectiva parede de concreto e tijolos. (fonte: ABNT, 2003 - editada pela autora)

a) Resistência térmica da parede de concreto com tijolos:

Seção A (concreto + argamassa + concreto)

$A a=(0,01 \times 0,32)+(0,01 \times 0,22)=0,0054 m^{2}$

$\mathrm{R}_{\mathrm{A}}=\frac{\mathrm{e}_{\text {concreto }}}{\lambda_{\text {concreto }}}+\frac{e_{\text {argamassa }}}{\lambda_{\text {argamassa }}}+\frac{e_{\text {concreto }}}{\lambda_{\text {concreto }}}=\frac{0,05}{1,75}+\frac{0,10}{1,15}+\frac{0,05}{1,75}=0,1441\left(\mathrm{~m}^{2} \mathrm{k}\right) / \mathrm{W}$

Seção B (concreto + tijolo + concreto)

$A b=0,01 \times 0,32=0,0032 m^{2}$

$\mathrm{Rb}=\frac{e_{\text {concreto }}}{\lambda_{\text {concreto }}}+\frac{e_{\text {cerâmica }}}{\lambda_{\text {cerâmica }}}+\frac{e_{\text {concreto }}}{\lambda_{\text {cerâmica }}}=\frac{0,05}{1,75}+\frac{0,10}{0,90}+\frac{0,05}{1,75}=0,16825\left(\mathrm{~m}^{2} \mathrm{k}\right) / \mathrm{W}$ 
Capítulo 5

Fazenda Pindorama: Casa-sede e Pavilhão

Seção C (concreto + tijolo + câmara de ar + tijolo + câmara de ar + tijolo + concreto)

$A_{c}=0,035 \times 0,32=0,0112 m^{2}$

$R_{c}=\frac{e_{\text {concreto }}}{\lambda_{\text {concreto }}}+\frac{e_{\text {cerâmica }}}{\lambda_{\text {concreto }}}+R_{\text {ar }}+\frac{e_{\text {cerâmica }}}{\lambda_{\text {cerâmica }}}+R_{\text {ar }}+\frac{e_{\text {cerâmica }}}{\lambda_{\text {cerâmica }}}+\frac{e_{\text {concreto }}}{\lambda_{\text {concreto }}}$

$R_{c}=\frac{0,05}{1,75}+\frac{0,015}{0,90}+0,16+\frac{0,015}{0,90}+0,16+\frac{0,015}{0,90}+\frac{0,05}{1,75}=0,4557\left(\mathrm{~m}^{2} \mathrm{k}\right) / \mathrm{W}$

\section{Resistência total da parede}

$R t=\frac{A_{a}+4 \times A_{b}+3 \times A_{c}}{\frac{A_{a}}{R_{a}}+\frac{4 \times A_{b}}{R_{b}}+\frac{3 \times A_{c}}{R_{c}}}=\frac{0,0054+4 \times 0,0032+3 \times 0,012}{\frac{0,0054}{0,1441}+\frac{4 \times 0,0032}{0,16825}+\frac{3 \times 0,0112}{0,4557}}$

$R_{t}=0,2766\left(\mathrm{~m}^{2} \mathrm{k}\right) / \mathrm{W}$

b) Resistência térmica total:

$R_{\dagger}=R_{s i}+R_{\dagger}+R_{s c}=0,2502+02766+0,04=0,5668\left(m^{2} k\right) / W$

\section{c) Transmitância térmica da parede:}

$U=\frac{1}{R_{\dagger}}=\frac{1}{05668}=1,7643 \mathrm{~W} /\left(\mathrm{m}^{2} \mathrm{k}\right)$

Onde:

A - É a área de cada seção $\left(\mathrm{m}^{2}\right)$.

$\mathbf{R}_{\mathbf{a}, \mathbf{b}, \mathbf{c}}$ - São as resistências térmicas de cada seção. Quociente da diferença de temperatura verificada entre as superfícies de um elemento ou componente construtivo pela densidade de fluxo de calor, em regime estacionário $\left[\left(\mathrm{m}^{2} . \mathrm{K}\right) / \mathrm{W}\right]$.

$\mathbf{R}_{\mathbf{s i}}$ - É a resistência superficial interna. Resistência da camada de ar adjacente à superfície interna de um componente que transfere calor por radiação e/ou convecção [(m².K)/W].

$\mathbf{R}_{\mathbf{s e}}$ - É a resistência superficial externa. Resistência da camada de ar adjacente à superfície externa de um componente que transfere calor por radiação e/ou convecção [(m².K)/W].

$\mathbf{R}_{\mathbf{f}}$ - É a resistência térmica total do elemento (parede). Somatório do conjunto de resistências térmicas correspondentes às camadas de um elemento ou componente, incluindo resistências superficiais interna e externa $\left[\left(\mathrm{m}^{2} . \mathrm{K}\right) / \mathrm{W}\right]$.

e - É a espessura de cada camada (m).

$\boldsymbol{\lambda}$ - São os valores de condutividade térmica de cada material. Propriedade física de um material homogêneo e isótropo, no qual se verifica um fluxo de calor constante, com densidade de $1 \mathrm{~W} / \mathrm{m}^{2}$, quando submetido a um gradiente de temperatura uniforme de 1 Kelvin por metro $[\mathrm{W} /(\mathrm{m} . \mathrm{K})]$.

U - É a transmitância térmica, definida pelo inverso da resistência térmica total [W/( $\left.\left.\mathrm{m}^{2} . K\right)\right]$. 
CASO 2: Parede de concreto.

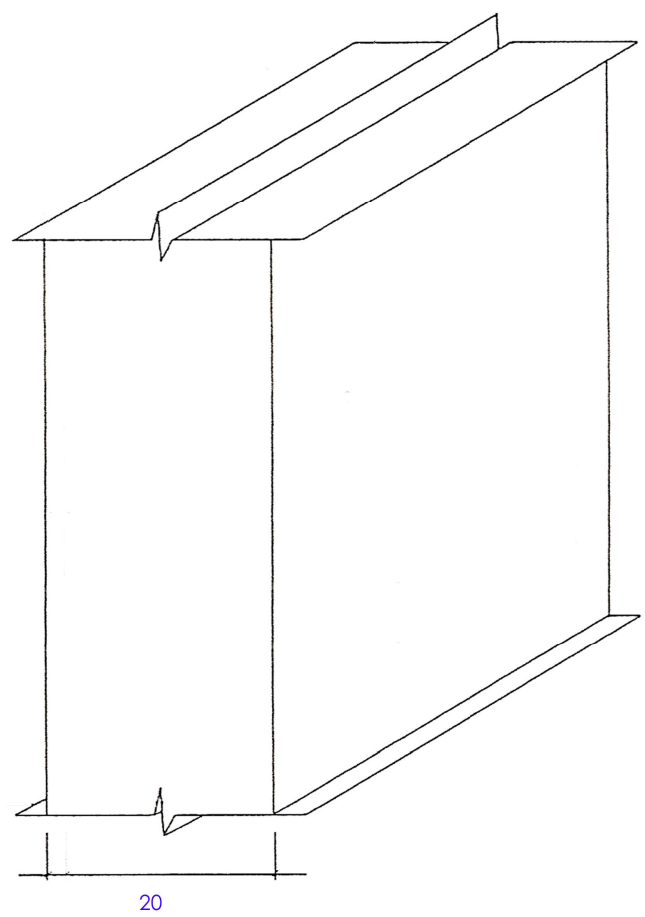

PAREDE

Fig. 5.28: Vista em perspectiva parede de concreto. (fonte: ABNT, 2003 - editada pela autora)

a) Resistência térmica da parede de concreto com tijolos:

$R_{t}=\frac{e_{\text {concreto }}}{\lambda_{\text {concreto }}}=\frac{0,20}{1,75}=0,1143\left(\mathrm{~m}^{2} \mathrm{k}\right) / \mathrm{W}$

b) Resistência térmica total:

$R_{t}=R_{s i}+R_{f}+R_{s e}=0,131+0,1143+0,04=, 02843\left(\mathrm{~m}^{2} k\right) / \mathrm{W}$

c) Transmitância térmica da parede:

$U=\frac{1}{R_{t}}=\frac{1}{0,2843}=3,5174 \mathrm{w} /\left(\mathrm{m}^{2} \mathrm{k}\right)$ 
Fazenda Pindorama: Casa-sede e Pavilhão

A resistência térmica total $\left(R_{T}\right)$ é a somatória do conjunto de resistências térmicas correspondentes às camadas de um elemento ou componente, incluindo as resistências superficiais interna e externa (ABNT, 2003).

A transmitância térmica ou coeficiente global de transferência de calor (U) é o inverso da resistência térmica total e indica a facilidade de um material ou uma composição de materiais transferir calor, isto é, quanto maior for o valor da transmitância, mais calor o material ou a composição será capaz de transmitir (ABNT, 2003).

De acordo com a norma, a cidade de Cabreúva, no interior do estado de São Paulo, localiza-se na zona bioclimática número 3, indicando que a transmitância térmica das vedações verticais deve ser $\mathrm{U} \leq 3,60 \mathrm{~W} / \mathrm{m}^{2} . \mathrm{K}$.

Apesar de ambas as soluções estarem dentro das indicações da norma, a parede sólida de concreto apresenta o dobro da transmitância térmica em relação à com enchimento de tijolos, estando praticamente no limite $(U=3,52$ $\mathrm{W} / \mathrm{m}^{2} . \mathrm{K}$ ) do valor que a norma recomenda.

A parede de concreto com enchimento em tijolos se apresenta mais vantajosa, pois apresenta uma transmitância térmica muito menor $(U=1,76$ $\left.\mathrm{W} / \mathrm{m}^{2} . \mathrm{K}\right)$, possuindo portanto melhor isolamento térmico e não ficando tão vulnerável às mudanças de temperatura como calor ou frio intenso. 


\subsection{Considerações sobre os projetos}

Na época da construção da casa-sede, a Construtora Cenpla, responsável pela obra, já vinha trabalhando com coberturas em abóbadas, utilizando variadas técnicas construtivas. Essa mesma construtora também foi responsável pela construção da residência Milan, de Acayaba, em concreto armado, e pela residência em Cotia, de Sérgio Ferro, em tijolos furados, esta, realizada com um sistema muito semelhante de fôrmas em cambotas reutilizáveis.

O projeto da casa-sede veio num momento posterior à experiência da residência Milan, cujo processo construtivo demandou bastante esforço e altos custos, na medida em que se utilizou um sistema construtivo um tanto quanto sofisticado. Acayaba, na casa-sede, já adota sistemas cujas técnicas construtivas dependem mais da mão de obra, utilizando materiais mais acessíveis, mesmo que combinados com o concreto. Provavelmente isso ocorreu por influência da produção e do discurso de Sérgio Ferro, que naquele momento fazia fortes críticas às "explorações de concepção e produção" advindas da tecnologia do concreto armado.

De qualquer forma, tanto no projeto da casa, quanto no do pavilhão, pareceme que o estudo da forma é que determinou o partido arquitetônico, e que as questões construtivas foram posteriormente definidas.

No entanto, são projetos que buscaram desenvolver soluções técnicas diferenciadas, mesmo que com referências formais diretas, e tentaram explorar as potencialidades dos materiais e das técnicas utilizadas, no sentido de que se tornassem adequados às necessidades estabelecidas pelo programa e pelo meio em que a obra se insere. 


\section{Capítulo 5}

Fazenda Pindorama: Casa-sede e Pavilhão

\subsection{Ficha técnica-Casa-sede}

\begin{tabular}{|c|c|c|}
\hline \multicolumn{3}{|l|}{ Dados gerais } \\
\hline \multicolumn{2}{|l|}{ Local: } & Bairro do Jacaré - Cabreúva - SP \\
\hline \multicolumn{2}{|l|}{ Ano do Projeto: } & 1974 \\
\hline \multicolumn{2}{|c|}{ Período da Construção: } & 1975 \\
\hline \multicolumn{3}{|l|}{ Equipe de Projeto } \\
\hline \multicolumn{3}{|c|}{ Arq. Marcos Acayaba } \\
\hline \multicolumn{3}{|c|}{ Arq. Augusto Lívio Malzoni } \\
\hline \multicolumn{3}{|l|}{ Colaboradores } \\
\hline \multicolumn{2}{|c|}{ Projeto de Fundações: } & Engesolos \\
\hline \multicolumn{2}{|l|}{ Calculo Estrutural: } & Eng. Ugo Tedeschi e Eng. Yukio Ogata \\
\hline \multicolumn{2}{|c|}{ Projeto de Instalações: } & Eng. Eurico Freitas Marques \\
\hline \multicolumn{2}{|c|}{ Projeto de Paisagismo: } & Plínio Toledo Piza \\
\hline \multicolumn{2}{|l|}{ Construção: } & Cenpla \\
\hline \multicolumn{3}{|l|}{ Programa } \\
\hline \multicolumn{3}{|l|}{ Sala de estar } \\
\hline \multicolumn{3}{|l|}{ Sala de jantar } \\
\hline \multicolumn{3}{|l|}{6 Dormitórios } \\
\hline \multicolumn{3}{|l|}{3 Sanitários } \\
\hline \multicolumn{3}{|l|}{ Cozinha } \\
\hline \multicolumn{3}{|l|}{ Lavanderia } \\
\hline \multicolumn{3}{|c|}{3 Dormitórios de empregada } \\
\hline \multicolumn{3}{|l|}{ Depósito } \\
\hline \multicolumn{3}{|l|}{ Garagem } \\
\hline \multicolumn{3}{|l|}{ Terraço coberto } \\
\hline \multicolumn{3}{|l|}{ Piscina } \\
\hline \multicolumn{3}{|l|}{ Materiais } \\
\hline Estrutura: & \multicolumn{2}{|c|}{ Alvenaria armada e pilares de aço } \\
\hline Cobertura: & \multicolumn{2}{|c|}{ Abóbadas armadas de blocos de concreto e laje de concreto } \\
\hline Alvenaria: & \multicolumn{2}{|c|}{ Blocos de concreto } \\
\hline Caixilhos: & \multicolumn{2}{|l|}{ Ferro } \\
\hline Acabamentos: & Bloco & arente, látex branco \\
\hline Pisos: & Ladril & hidráulico (liso e gretado) vermelho, carpete e epóxi vermelho \\
\hline Áreas & & \\
\hline Área Construída: & 767,0 & \\
\hline Área Útil: & 373,0 & \\
\hline
\end{tabular}




\section{Capítulo 5}

Fazenda Pindorama: Casa-sede e Pavilhão

\subsection{Ficha técnica - Pavilhão Pindorama}

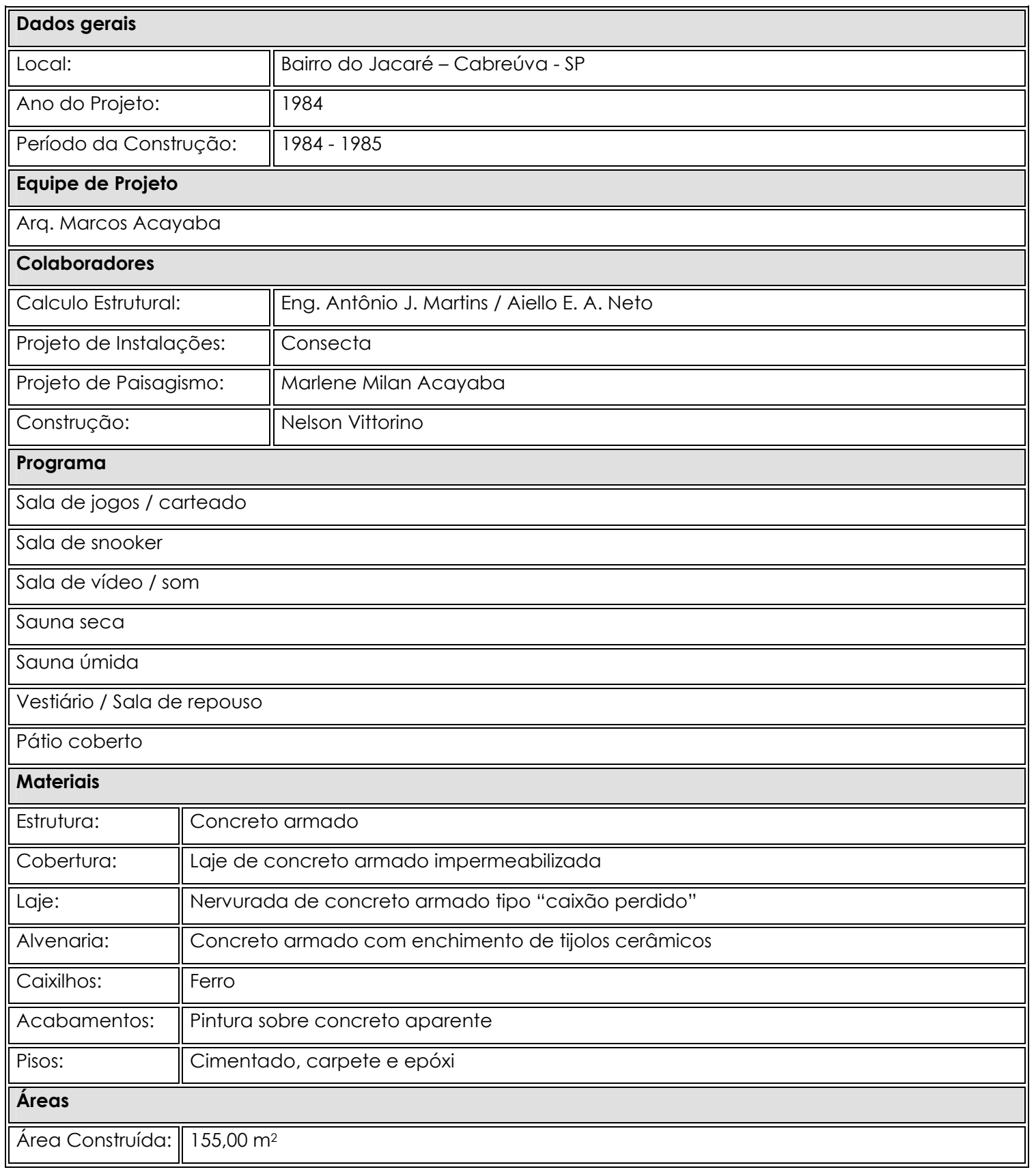




\section{CAPÍTULO 6:}

RESIDÊNCIA HÉLIO OLGA (São Paulo - SP, 1987-1990)

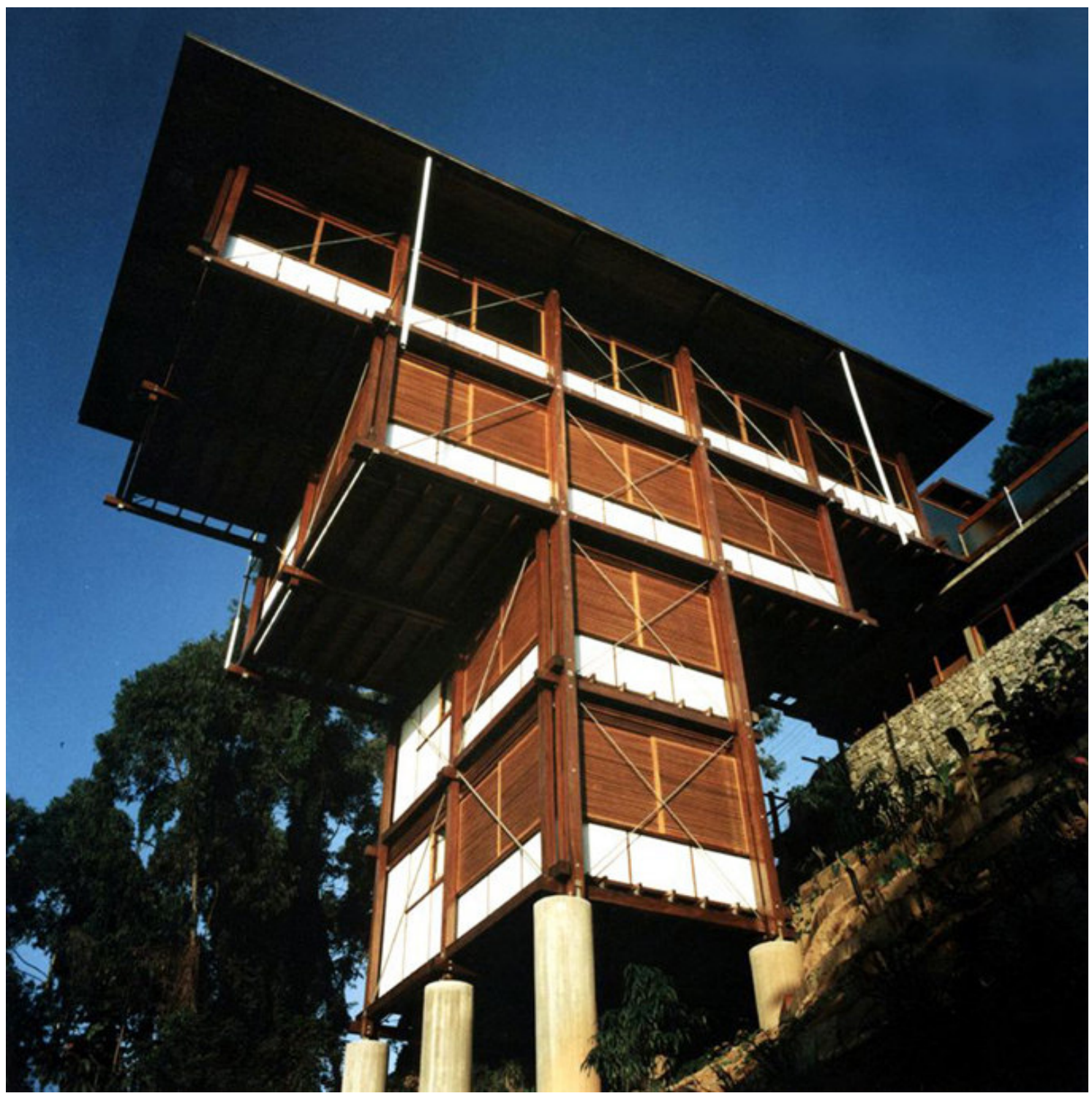

Fig. 6.1: Residência Hélio Olga. Vista da base do terreno. (fonte: arquivo pessoal Marcos Acayaba) 
Capítulo 6

Residência Hélio Olga

\subsection{O projeto}

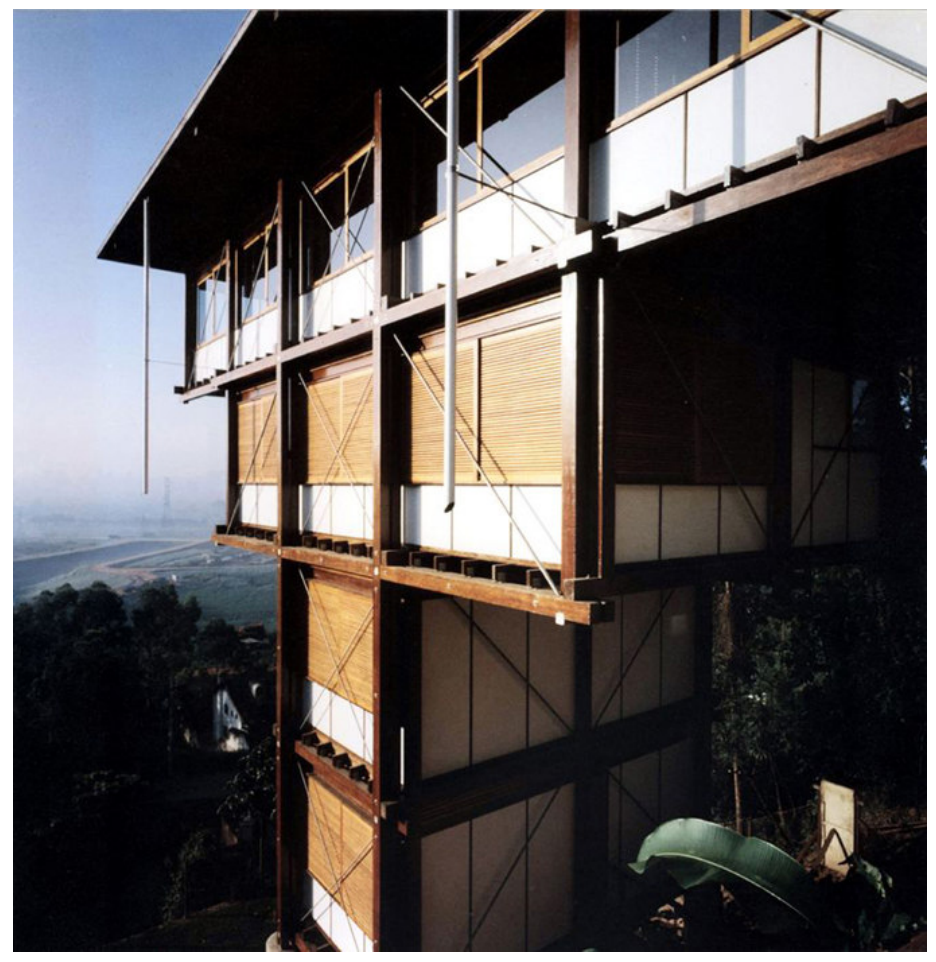

Fig. 6.2: Vista lateral. (fonte: arquivo pessoal Marcos Acayaba)

Esse projeto iniciou-se com um desafio: o terreno tinha mais de $100 \%$ de declividade, o que traria sério risco de erosões e impossibilitaria a implantação de um canteiro de obras tradicional. Por isso, o engenheiro Hélio Olga de Souza Júnior, proprietário do terreno e fabricante de estruturas em madeira, já previa a adoção de um sistema pré-fabricado em madeira, por permitir uma boa agilidade durante a obra, além de gerar pouco entulho. Mas segundo Hélio, ele não sabia como implantar e desenvolver o programa de uma casa naquelas condições (informação verbal) '

Foi então que decidiu procurar Acayaba, que desenvolveu um modo de implantação perpendicular ao terreno, aproveitando a insolação leste / oeste, já que outro desafio era o fato do terreno ser voltado para o sul e receber a intensa umidade que vem da represa de Guarapiranga.

\footnotetext{
1 Informação cedida por Hélio Olga em visita a sua residência.
} 
Capítulo 6

Residência Hélio Olga

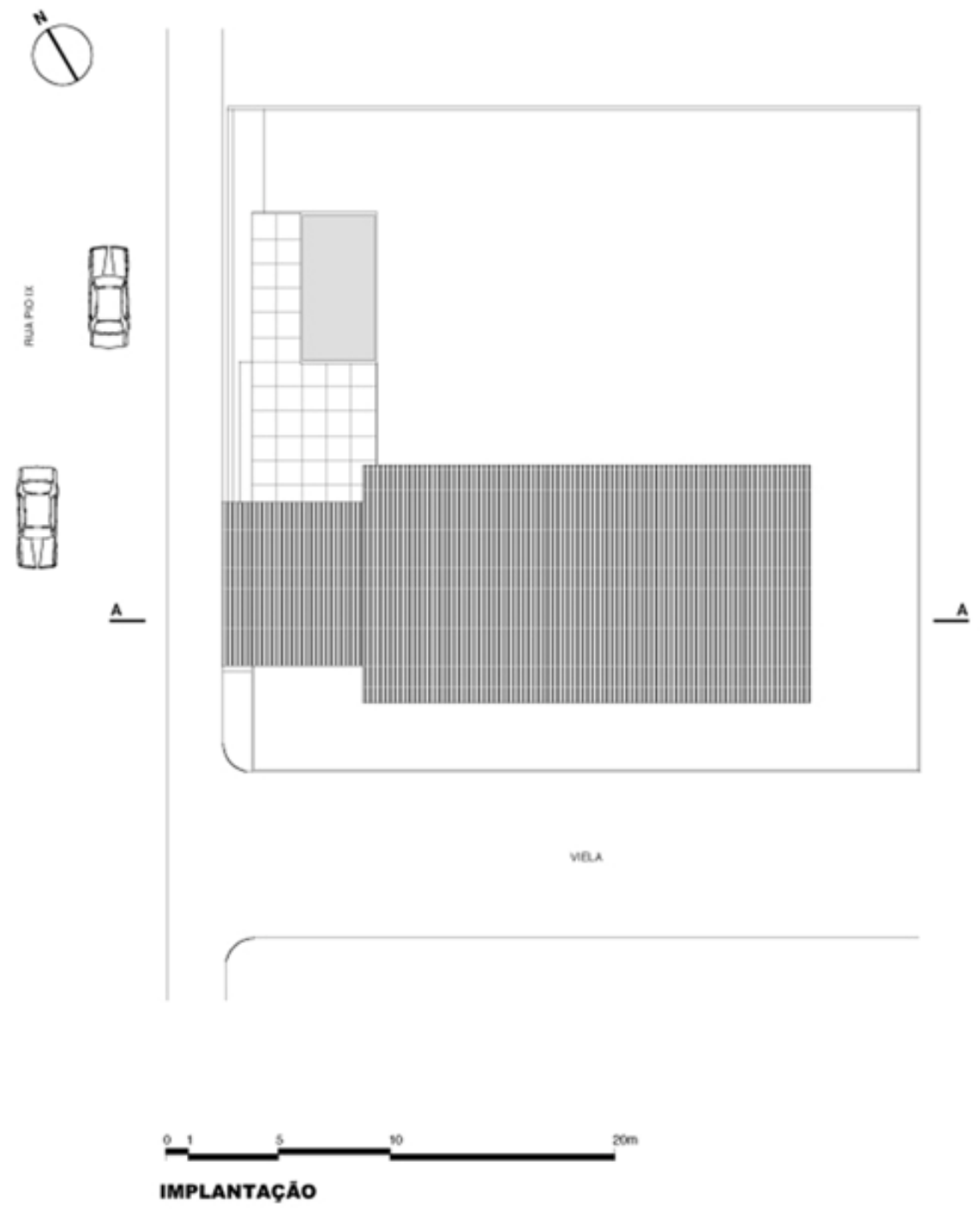

Fig. 6.3: Implantação. (fonte: arquivo pessoal Marcos Acayaba) 
Capítulo 6

Residência Hélio Olga

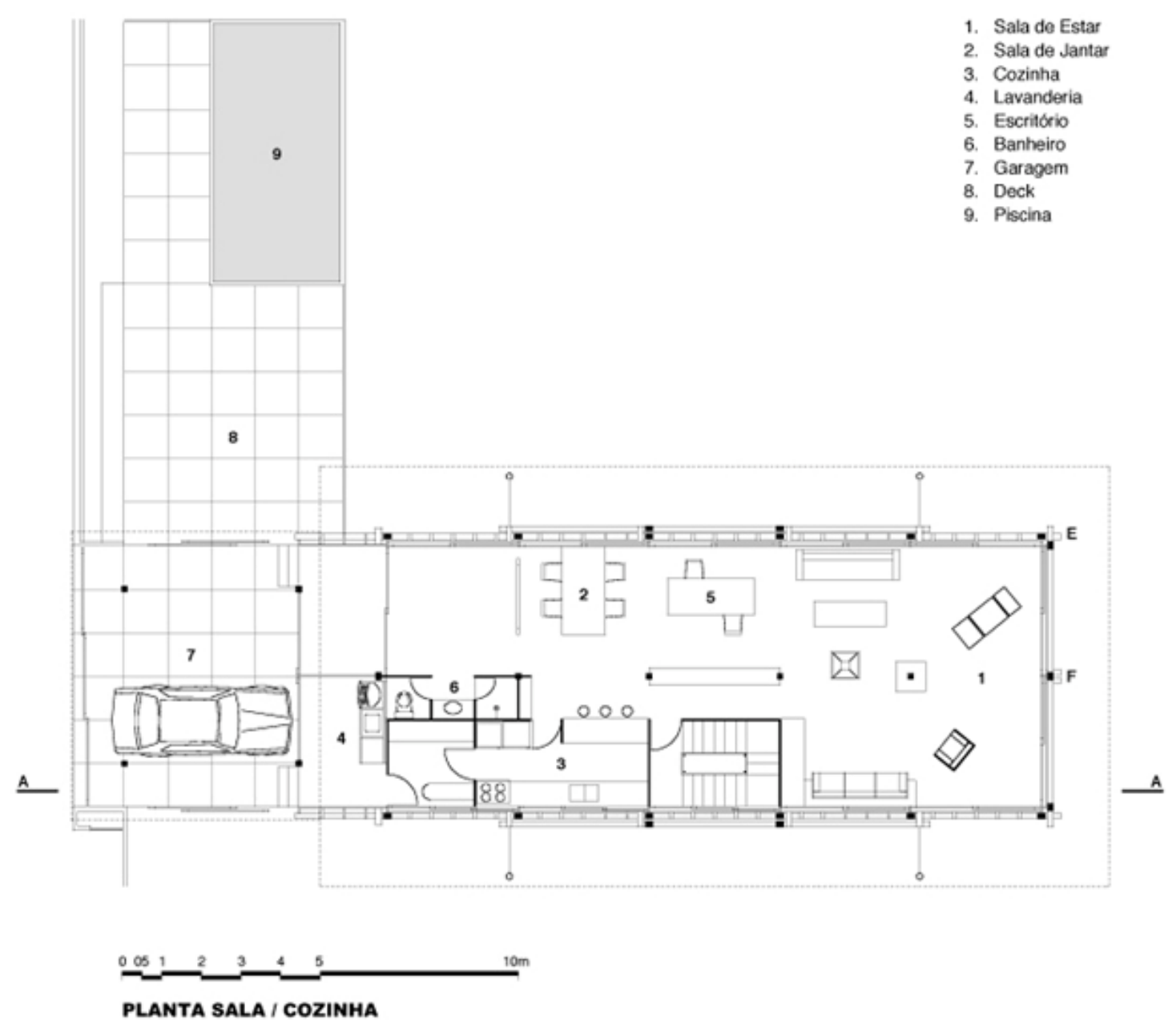

Fig. 6.4: Planta do nível de entrada, sala e cozinha (quarto pavimento). (fonte: arquivo pessoal Marcos Acayabal 
Capítulo 6

Residência Hélio Olga

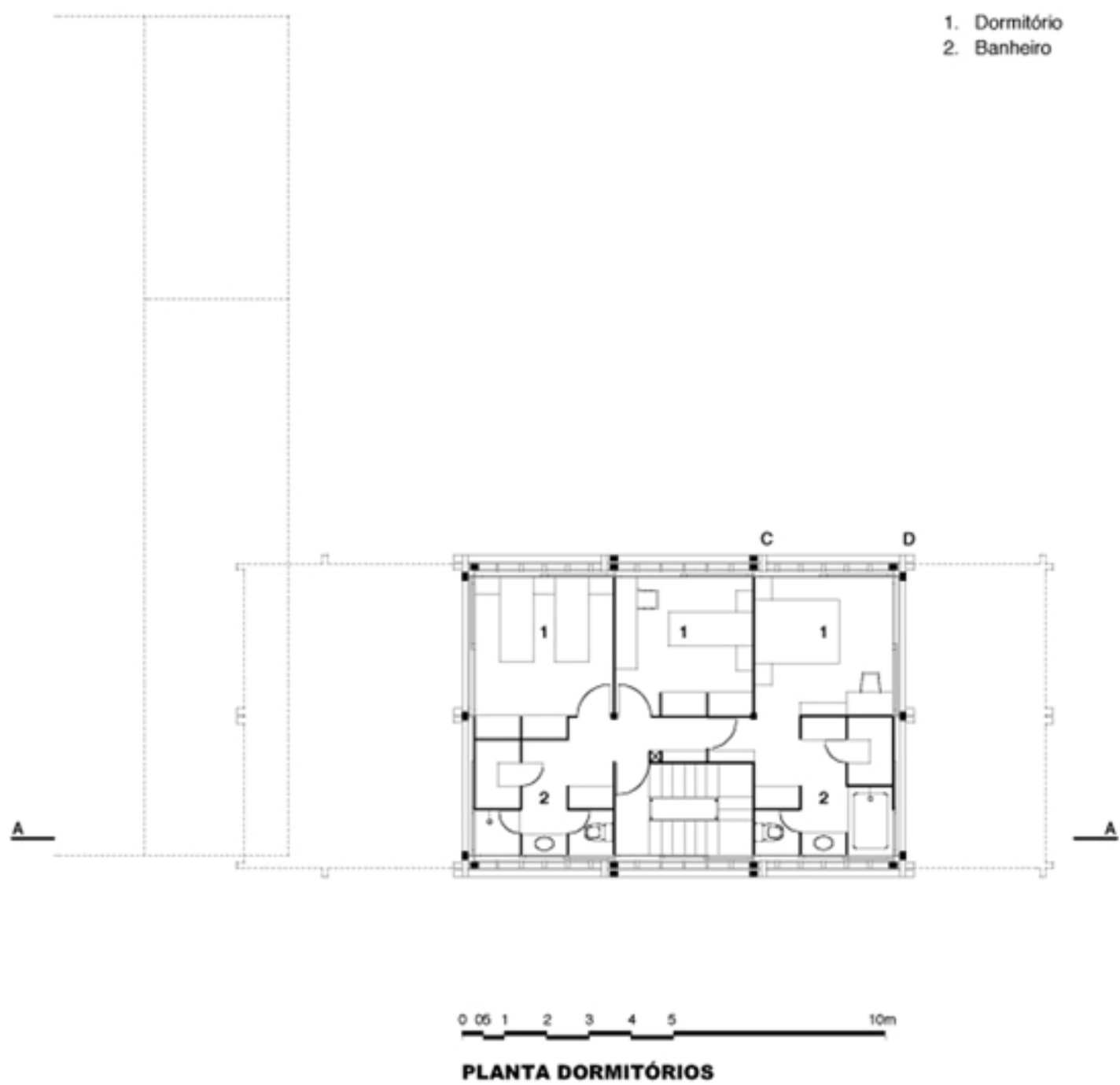

Fig. 6.5: Planta do nível dos quartos (terceiro pavimento). (fonte: arquivo pessoal Marcos Acayabal 
Capítulo 6

Residência Hélio Olga
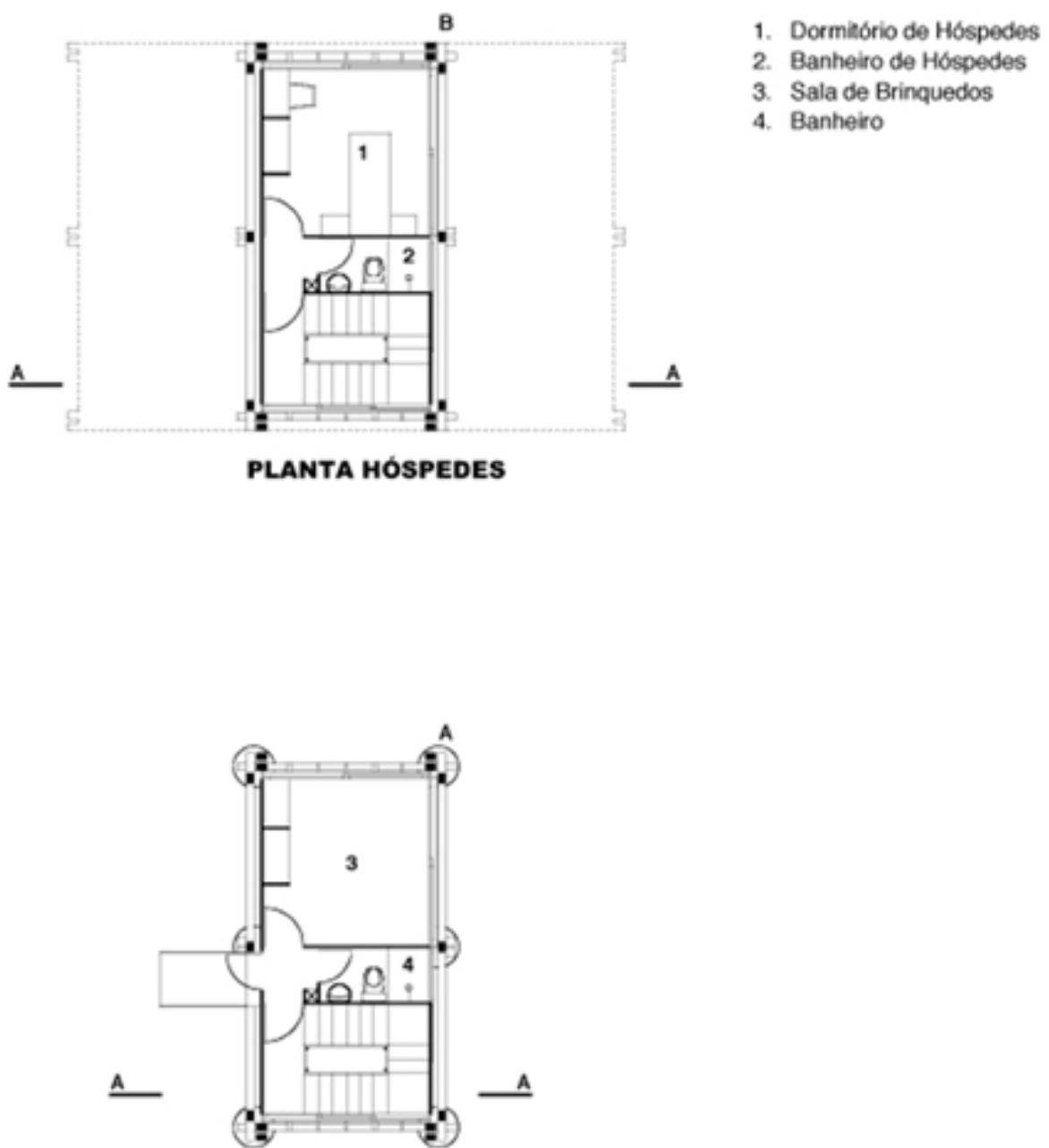

PLANTA S. BRINQUEDOS

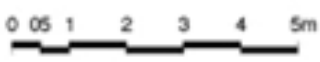

Fig. 6.6: Plantas dos níveis inferiores (segundo e primeiro pavimento, respectivamente). (fonte: arauivo Dessoal Marcos Acavabal 


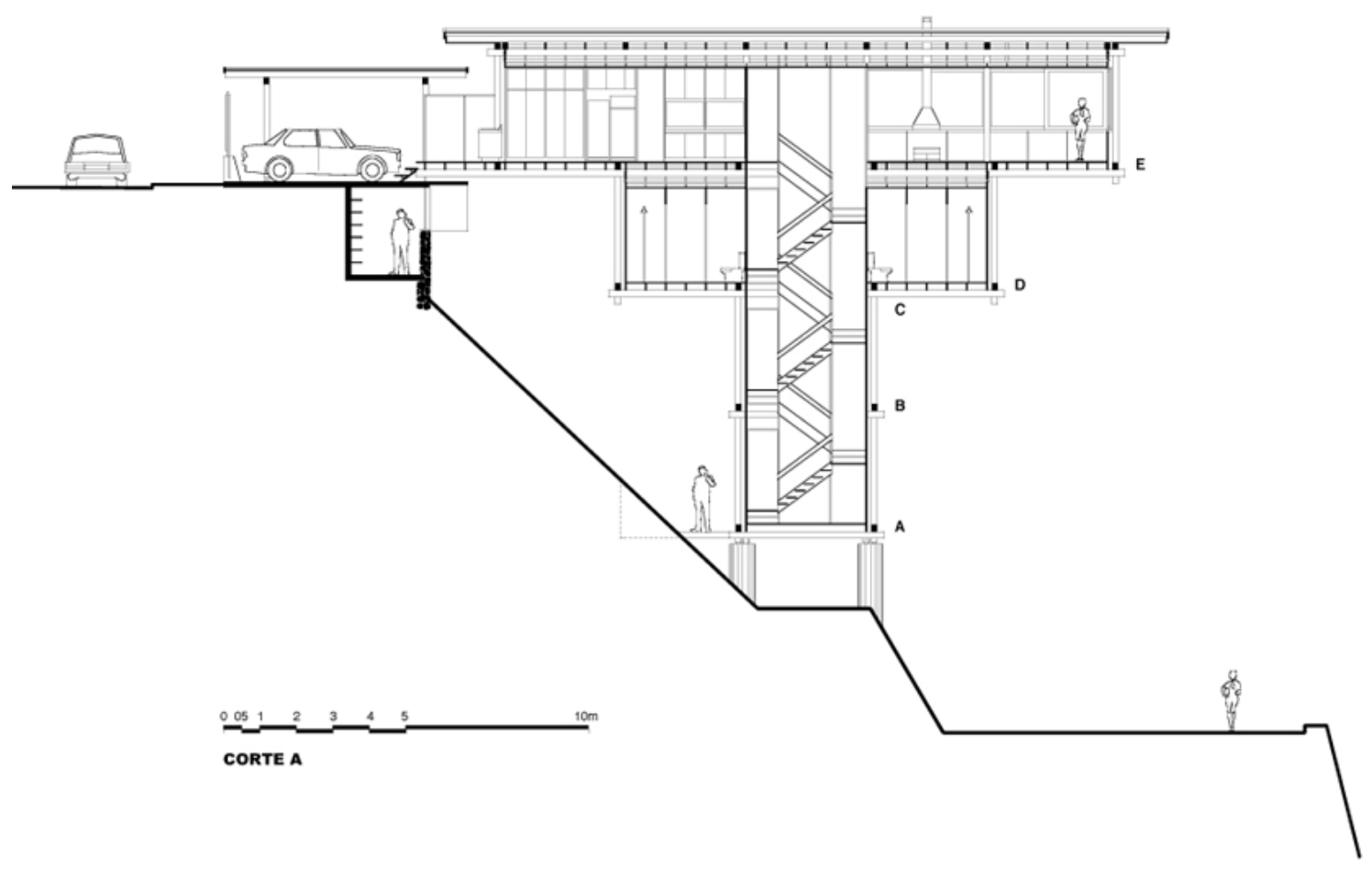

Fig. 6.7: Corte. (fonte: arquivo pessoal Marcos Acayaba)

Adotou-se um sistema modular de 3,30 x 3,30 × 3,30 m, em que os módulos se articulam em quatro pavimentos, invertendo a organização "padrão" da maioria dos projetos de residência. No quarto piso, por onde se dá o acesso, localizam-se a sala e a cozinha. No terceiro, três dormitórios, no segundo, um dormitório de hóspedes e no primeiro, uma sala de brinquedos.

A casa é elevada e apóia-se em somente seis pontos, dispensando grandes cortes, aterramentos e muros de arrimo. Intervém o mínimo possível no terreno, cujo subsolo já é cheio de entulho. Foram utilizados sistemas leves de vedações e cobertura para minimizar o peso total da construção.

Todas as peças são medidas e cortadas ainda na serraria, onde se concentram os maiores esforços de construção, já que toda a estrutura chega à obra pré-montada. A montagem final em canteiro foi então realizada em apenas 45 dias. 
Capítulo 6

Residência Hélio Olga

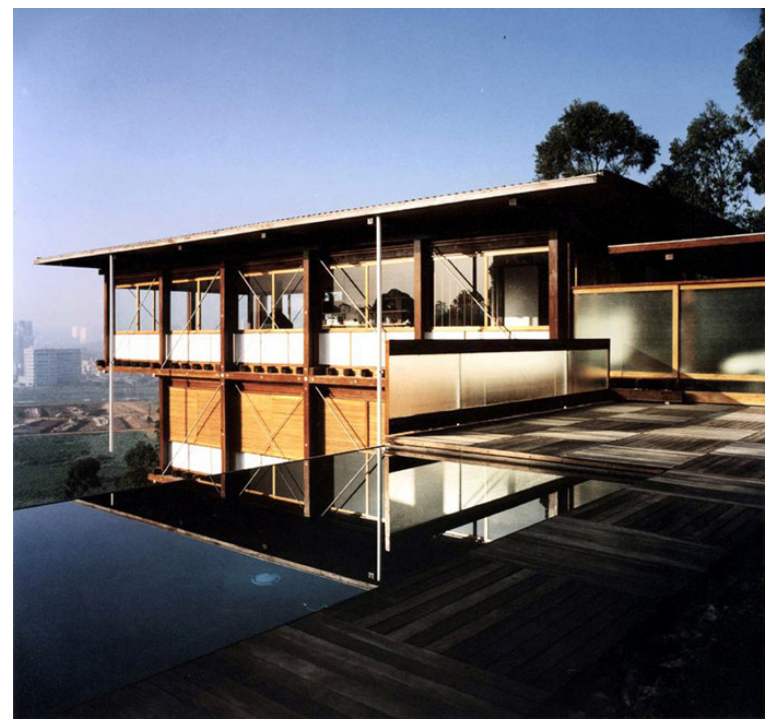

Fig. 6.8: Vista deck da piscina. (fonte: arquivo pessoal Marcos Acayaba)

O resultado é uma arquitetura inovadora, de forte expressão plástica. Segundo Hugo Segawa, "[...] arquitetura da lógica e da beleza, onde nada sobra e nada falta" (SEGAWA, 1996, p.28).

Esse projeto foi o primeiro de uma série de experiências em áreas de grande declividade dando início ao desenvolvimento de diversos sistemas préfabricadas em madeira, num processo de experimentação técnica e formal, em parceria com o engenheiro Hélio Olga.
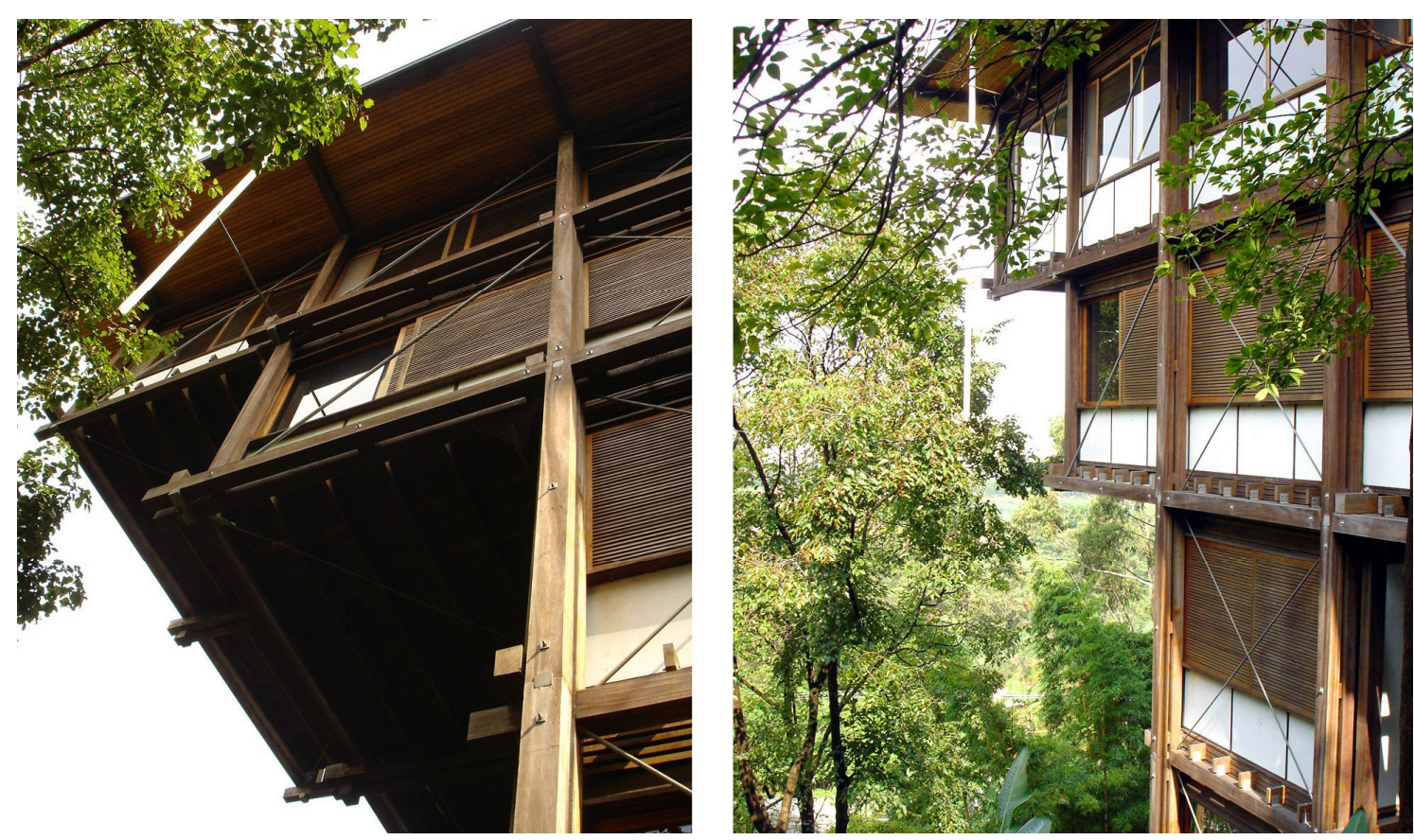

Fig. 6.9: Vistas gerais. (fonte: autora) 
Capítulo 6

Residência Hélio Olga
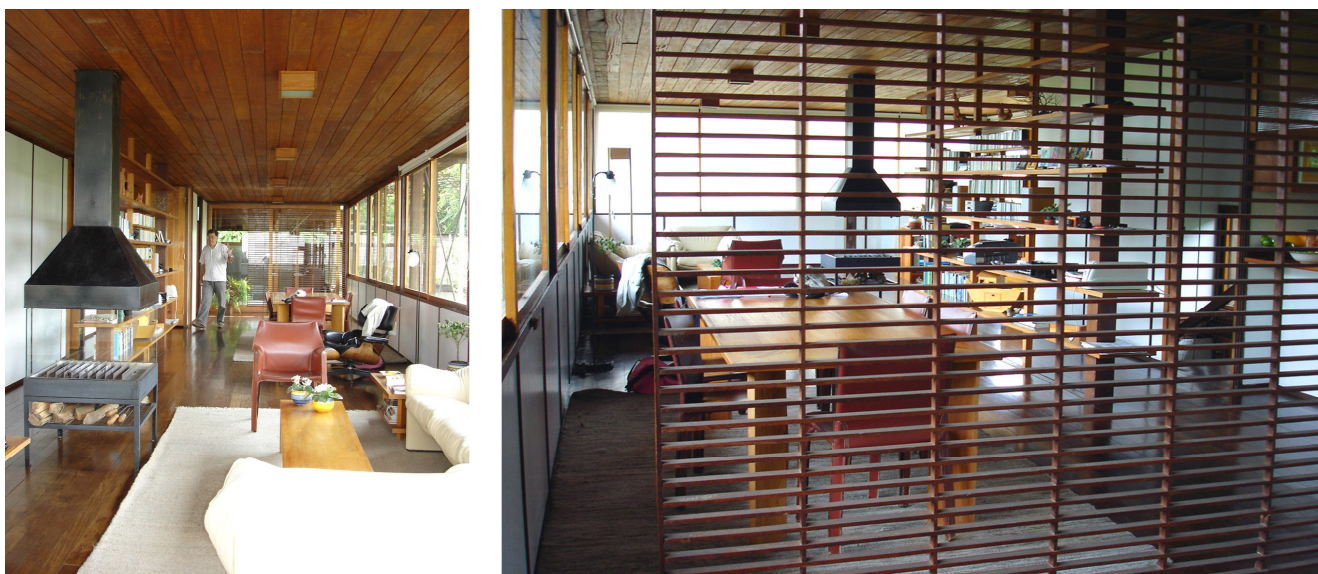

Fig. 6.10: Vistas internas. Sala. (fonte: autora)
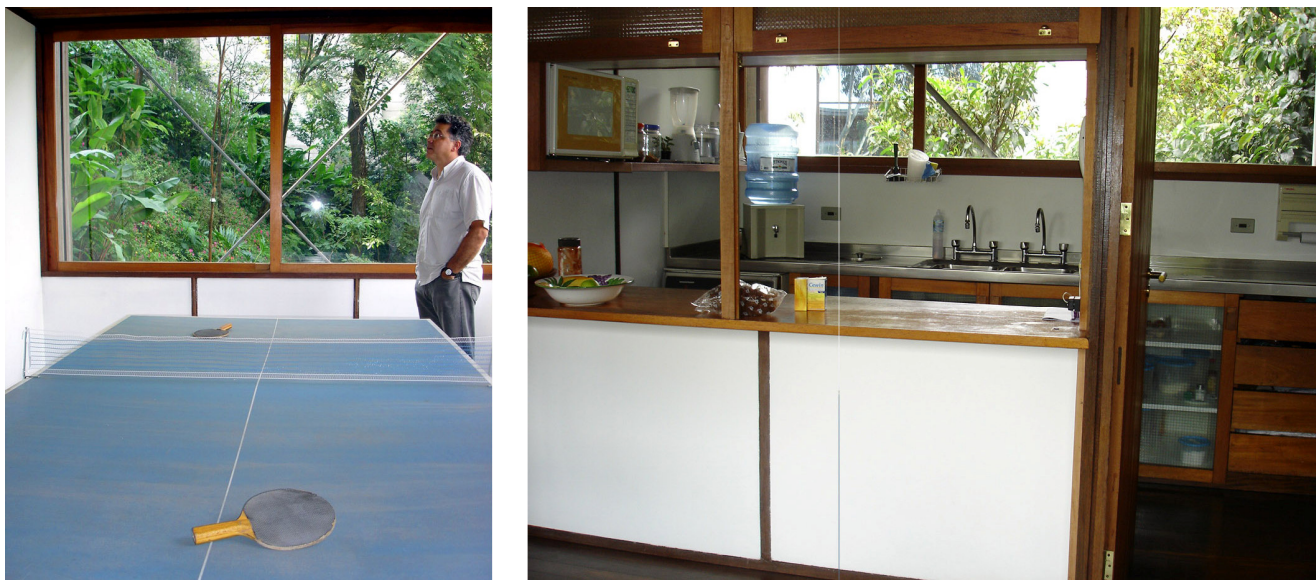

Fig. 6.11: Sala de brinquedos e cozinha. (fonte: autora)
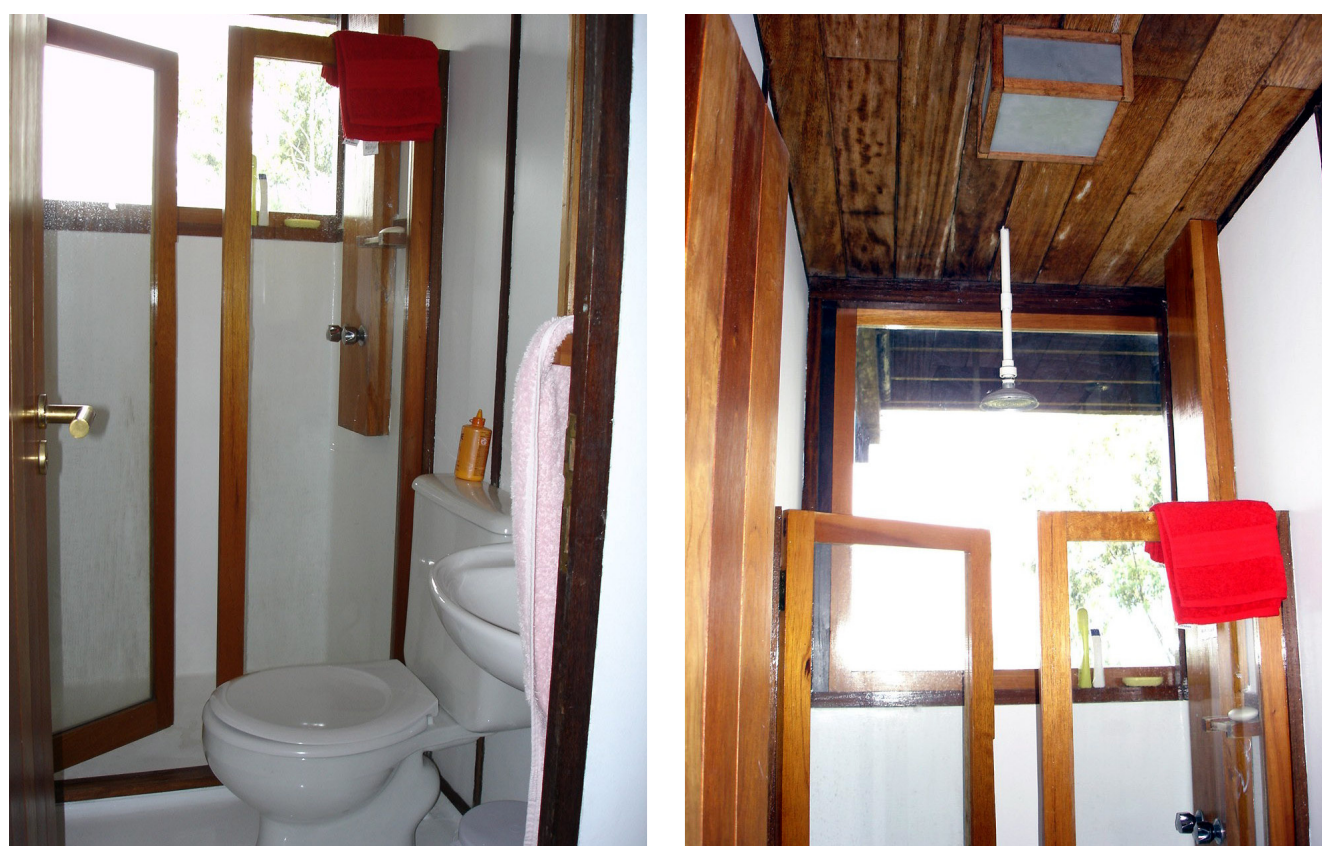

Fig. 6.12: Sanitário. Acabamento em fiber-glass (plástico reforçado com fibra de vidro). Shaft em madeira para passagem de instalações hidráulicas. (fonte: autora) 
Capítulo 6

Residência Hélio Olga

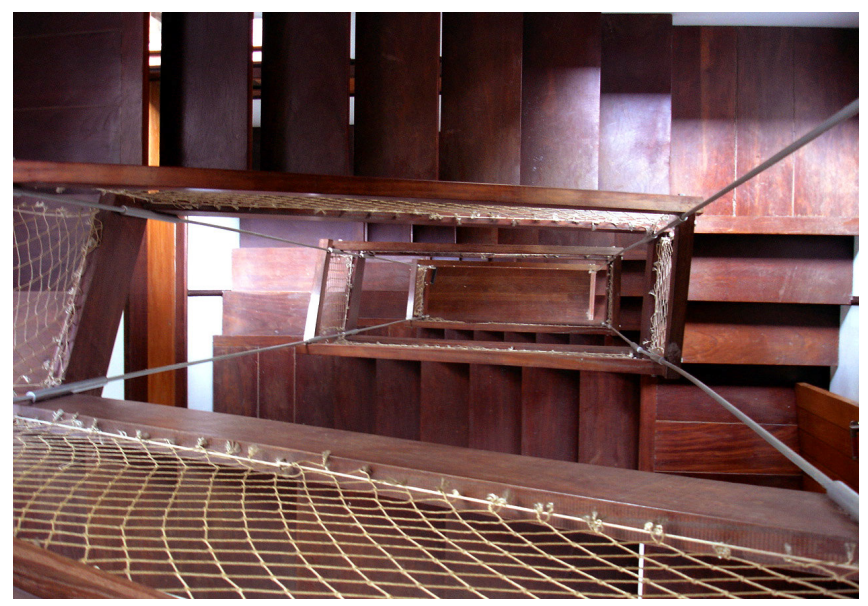

Fig. 6.13: Escada em madeira e tirantes de aço. (fonte: autora)

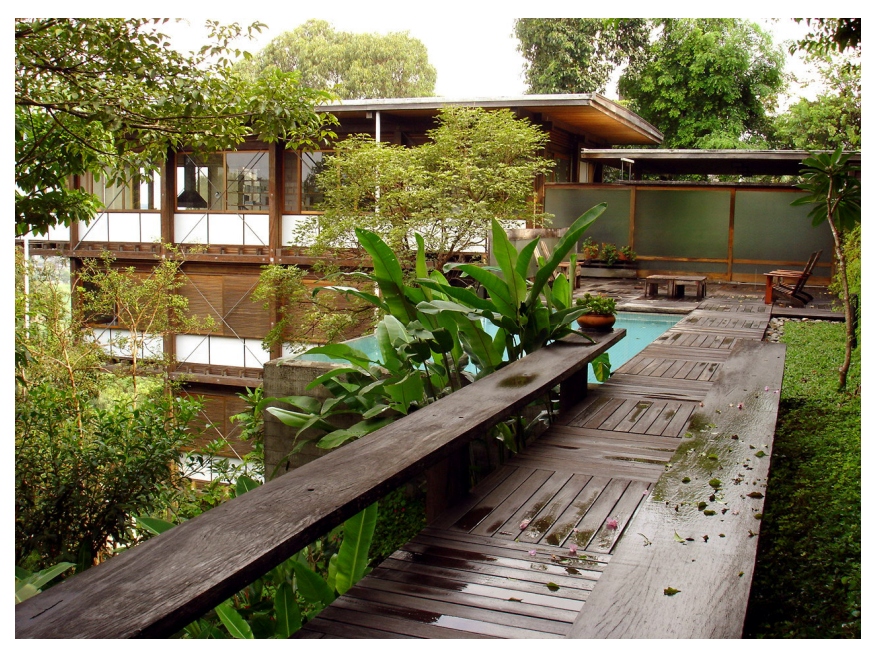

Fig. 6.14: Deck de acesso à residência. (fonte: autora)

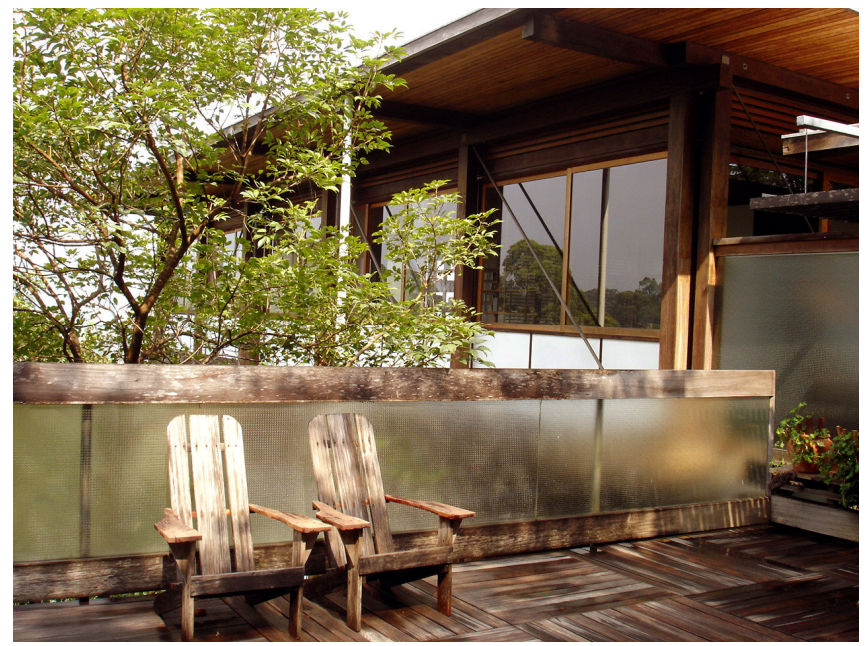

Fig. 6.15: Guarda-corpo em vidro e madeira. (fonte: autora) 


\subsection{A solução construtiva:}

Estrutura em madeira pré-fabricada em terreno de alta declividade

O primeiro contato de Acayaba com as estruturas em madeira se deu em 1986, no projeto da residência Oscar Teiman, no Guarujá. As soluções formais e técnicas utilizadas partiram de uma referência à arquitetura japonesa.

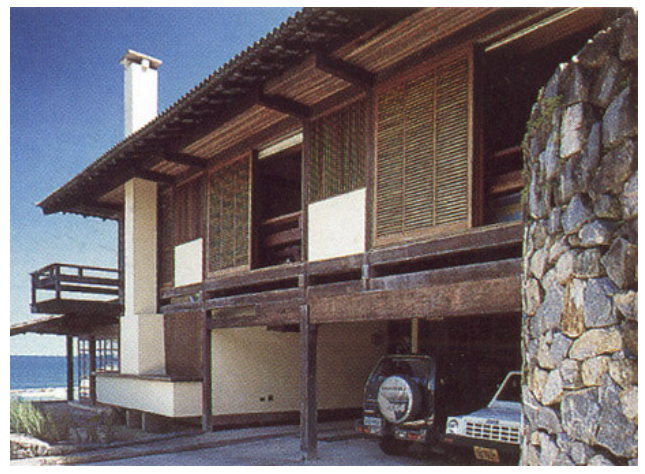

Fig. 6.16: Residência Oscar Teiman. (fonte: arquivo pessoal Marcos Acayaba)

Na ocasião, estabeleceu-se o primeiro contato entre Acayaba e o engenheiro Hélio Olga que, no ano seguinte, procurou o arquiteto para realizar o projeto de sua casa.

De acordo com Hélio Olga (SOUZA JR., 2007a), os encaixes e dimensionamentos finais da estrutura ficaram a cargo dele, mas todo o arranjo estrutural e o pré-dimensionamento foram definidos por Acayaba já nos primeiros desenhos.
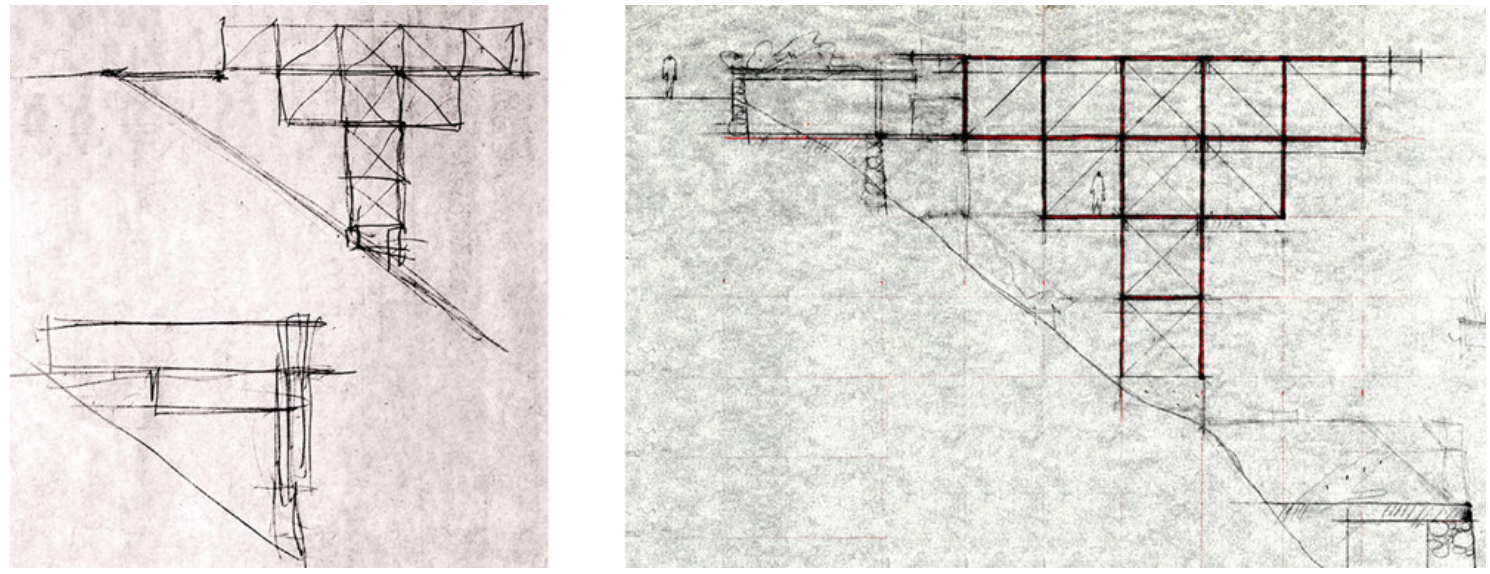

Fig. 6.17: Croquis de Marcos Acayaba. (fonte: arquivo pessoal Marcos Acayaba) 
Residência Hélio Olga

A
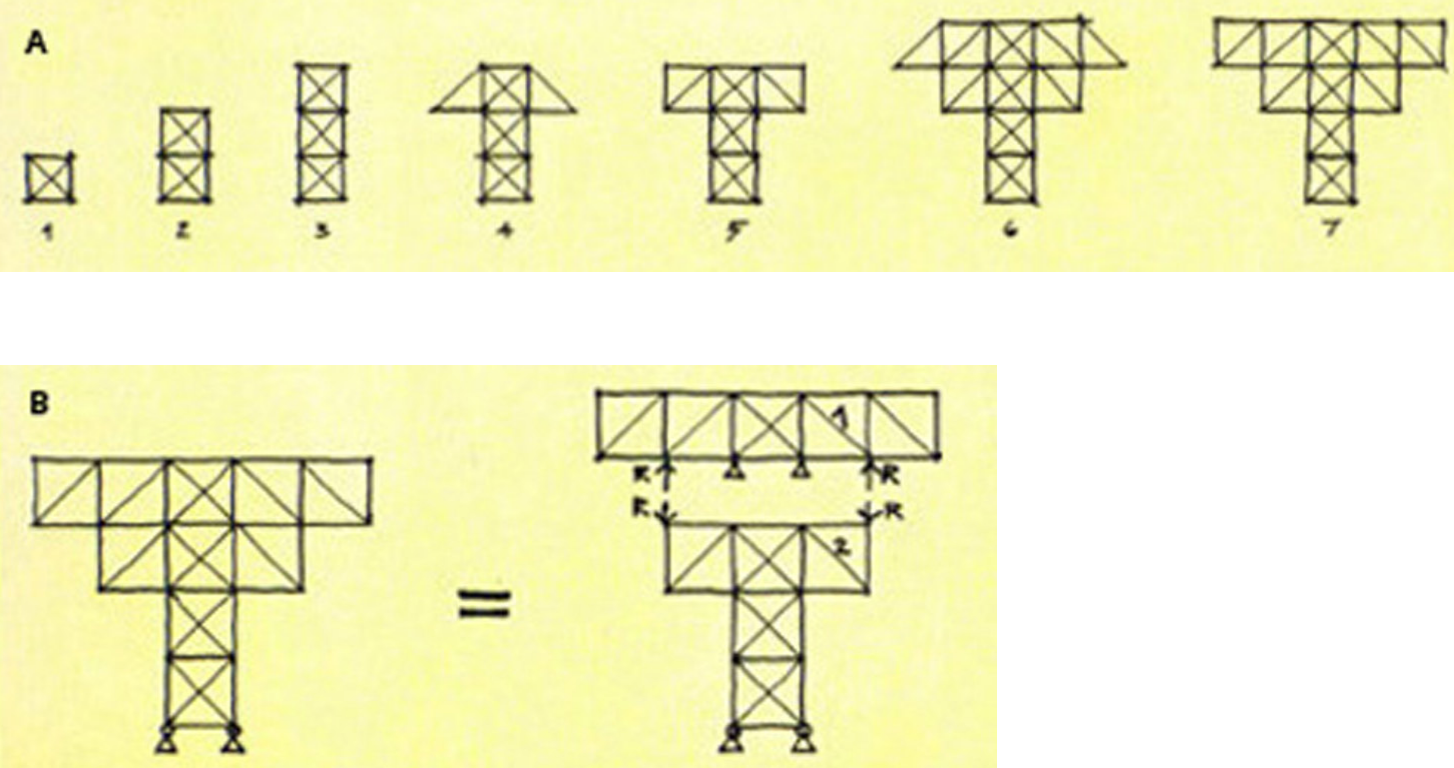

Fig. 6.18: Esquema estrutural desenhado por Acayaba. (fonte: arquivo pessoal Marcos Acayaba)

O desenvolvimento do partido estrutural ocorreu concomitantemente à definição do programa e da implantação, seguindo uma concepção modular de projeto, na qual o programa se distribui por 20 módulos cúbicos de 3,30m x $3,30 \mathrm{~m} \times 3,30 \mathrm{~m}$ escalonados e agrupados dois a dois.

A medida base da modulação é de $1,10 \mathrm{~m}$, devido à largura das placas de utilizadas como vedação (painel wall, ver p. 100), evitando cortes e desperdício de material. Em cada módulo é previsto em pé-direito de 2,50m. Na parte superior ficam $0,80 \mathrm{~m}$ para passagem de instalações.

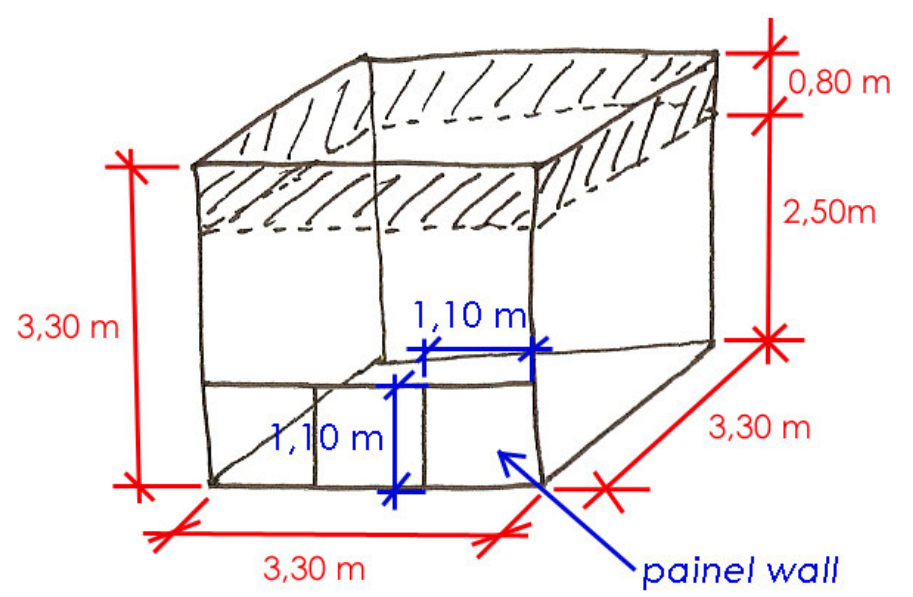

Fig. 6.19: Croqui. Modulo básico. (fonte: autora) 
Capítulo 6

Residência Hélio Olga
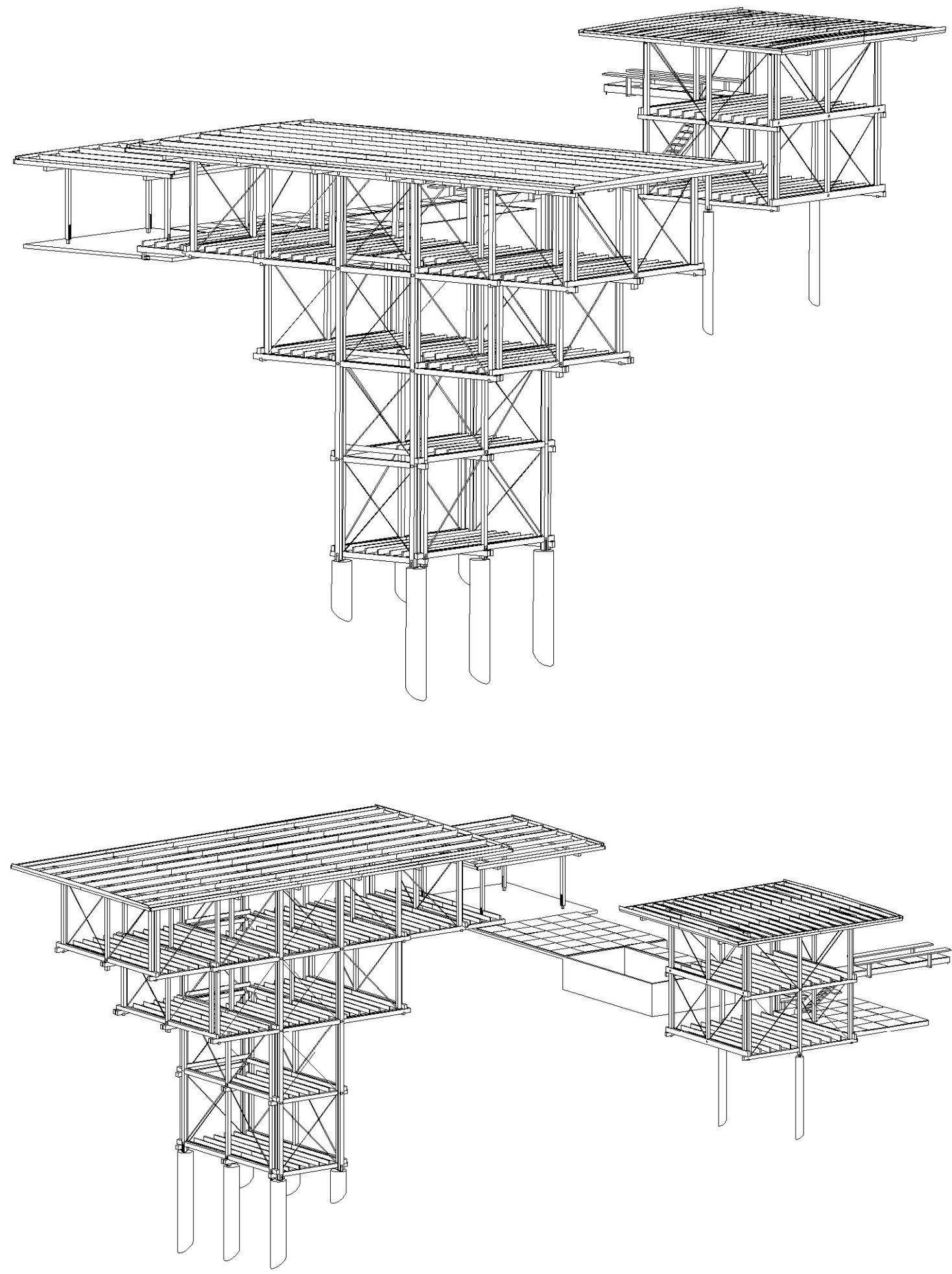

Fig. 6.20: Perspectivas do sistema estrutural. Residência e escritório. (fonte: arquivo pessoal Hélio Olga) 


\section{Capítulo 6}

Residência Hélio Olga

Seguindo a medida base de 1,10 m, pode-se trabalhar na composição de módulos maiores, como no caso do escritório, que Hélio construiu posteriormente ao lado de sua casa, seguindo modulação de 5,50 m x 5,50 m $\times 3,30 \mathrm{~m}$.
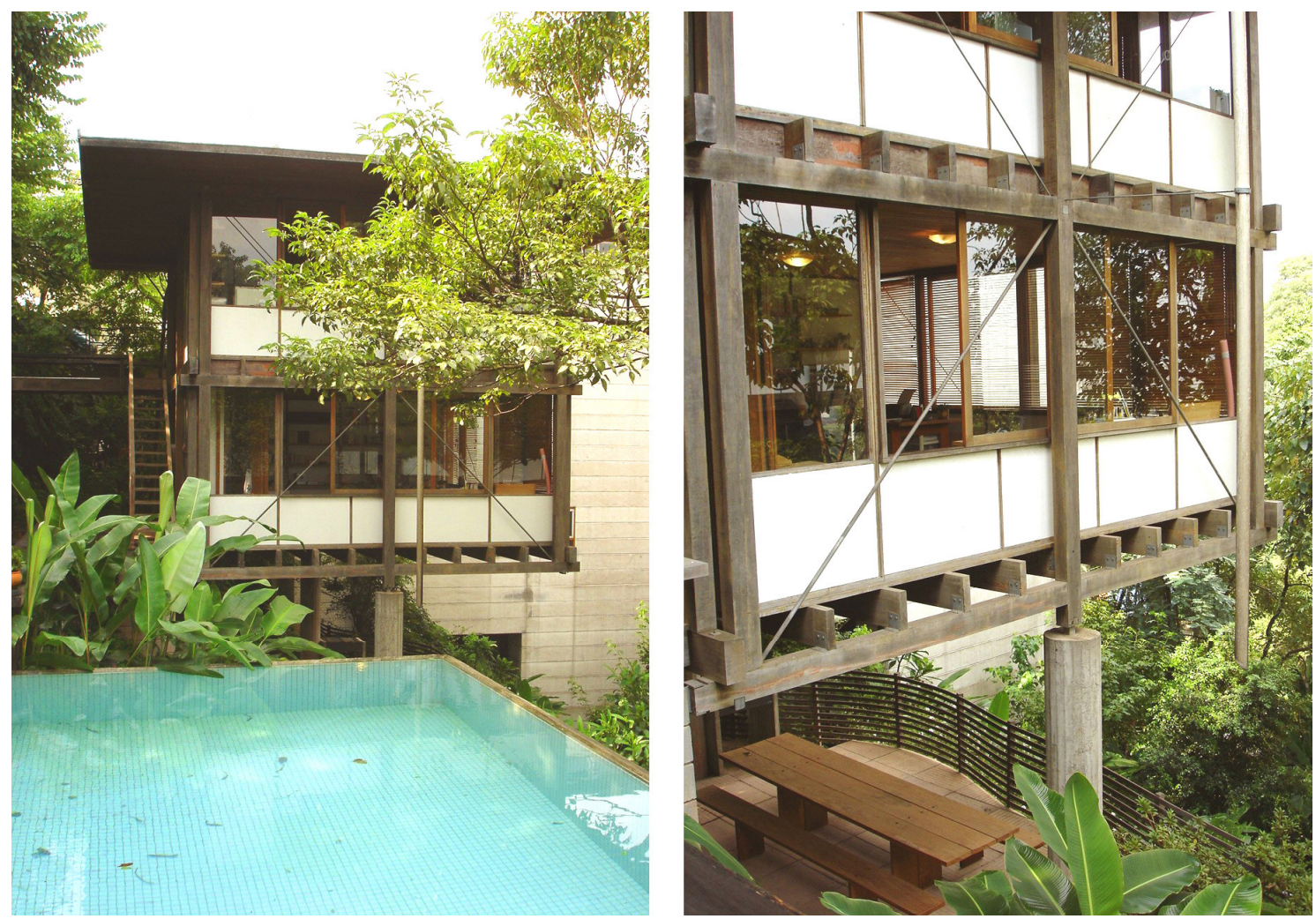

Fig. 6.21: Escritório. Mesmo sistema estrutural, mas seguindo modulação de $5,50 \mathrm{~m} \times 5,50 \mathrm{~m} \times$ $3,30 \mathrm{~m}$. (fonte: autora)

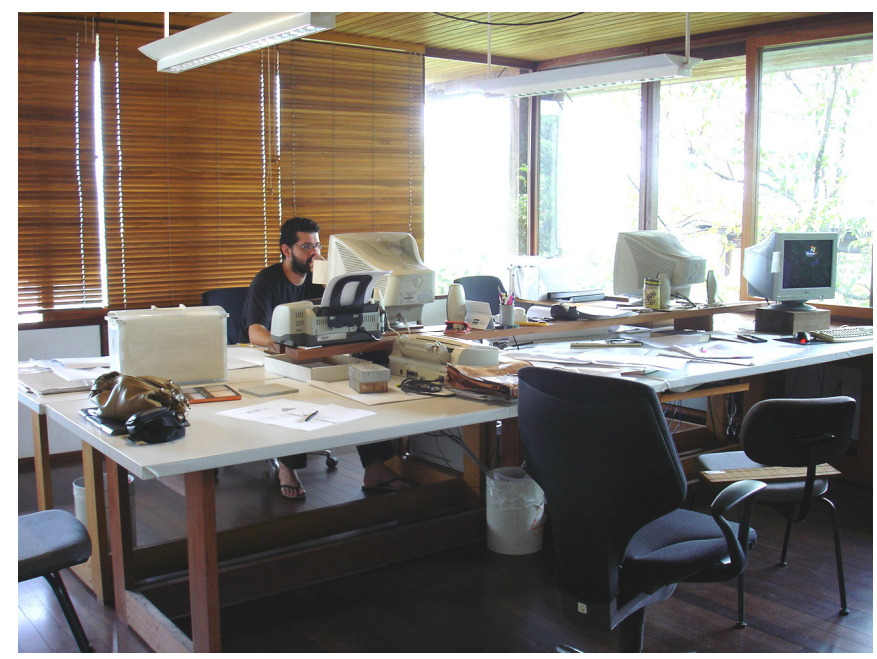

Fig. 6.22: Interior do edifício de escritório. (fonte: autora) 


\section{Capítulo 6}

Residência Hélio Olga

Os contraventamentos são compostos por vergalhões de aço galvanizado fixados por tarugos, também em aço galvanizados, rosqueados à estrutura de madeira. Eles impedem que o edifício sofra deformações nos sentidos horizontal e vertical da estrutura, como mostra a figura a seguir.
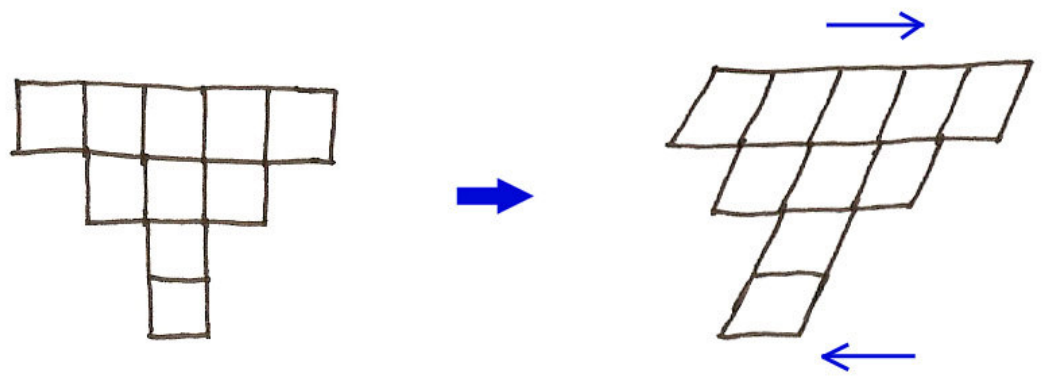

corte

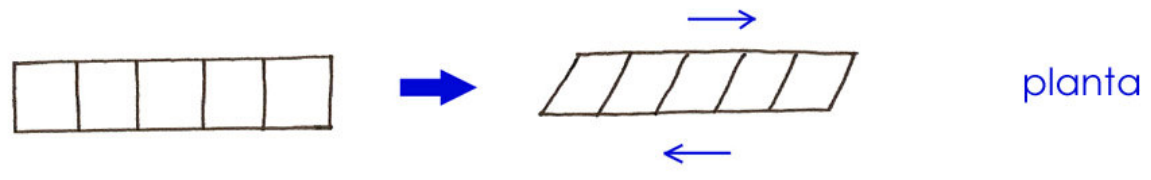

Fig. 6.23: Movimento de deformação em corte e planta. (fonte: autora)
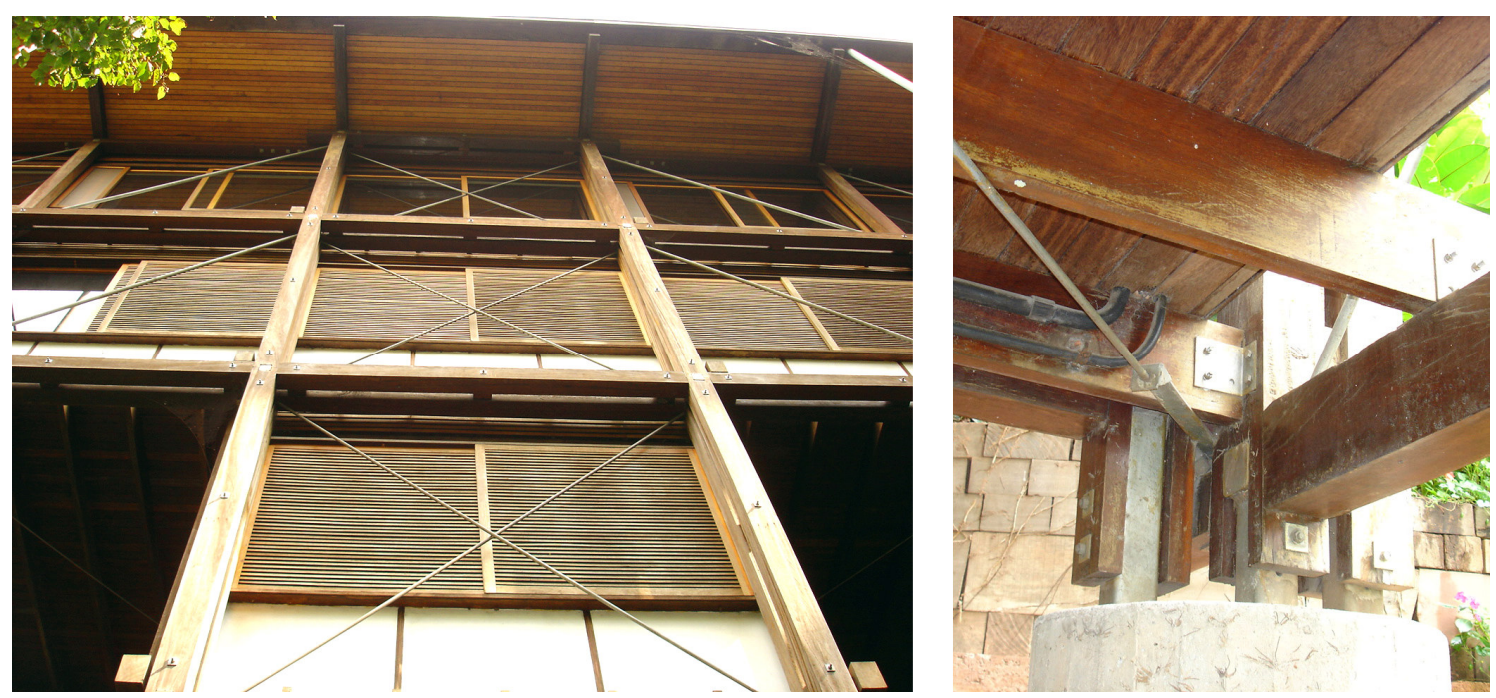

Fig. 6.24: Contraventamento vertical na fachada e horizontal fixado ao nó estrutural abaixo do piso. (fonte: autora) 
Capítulo 6

Residência Hélio Olga

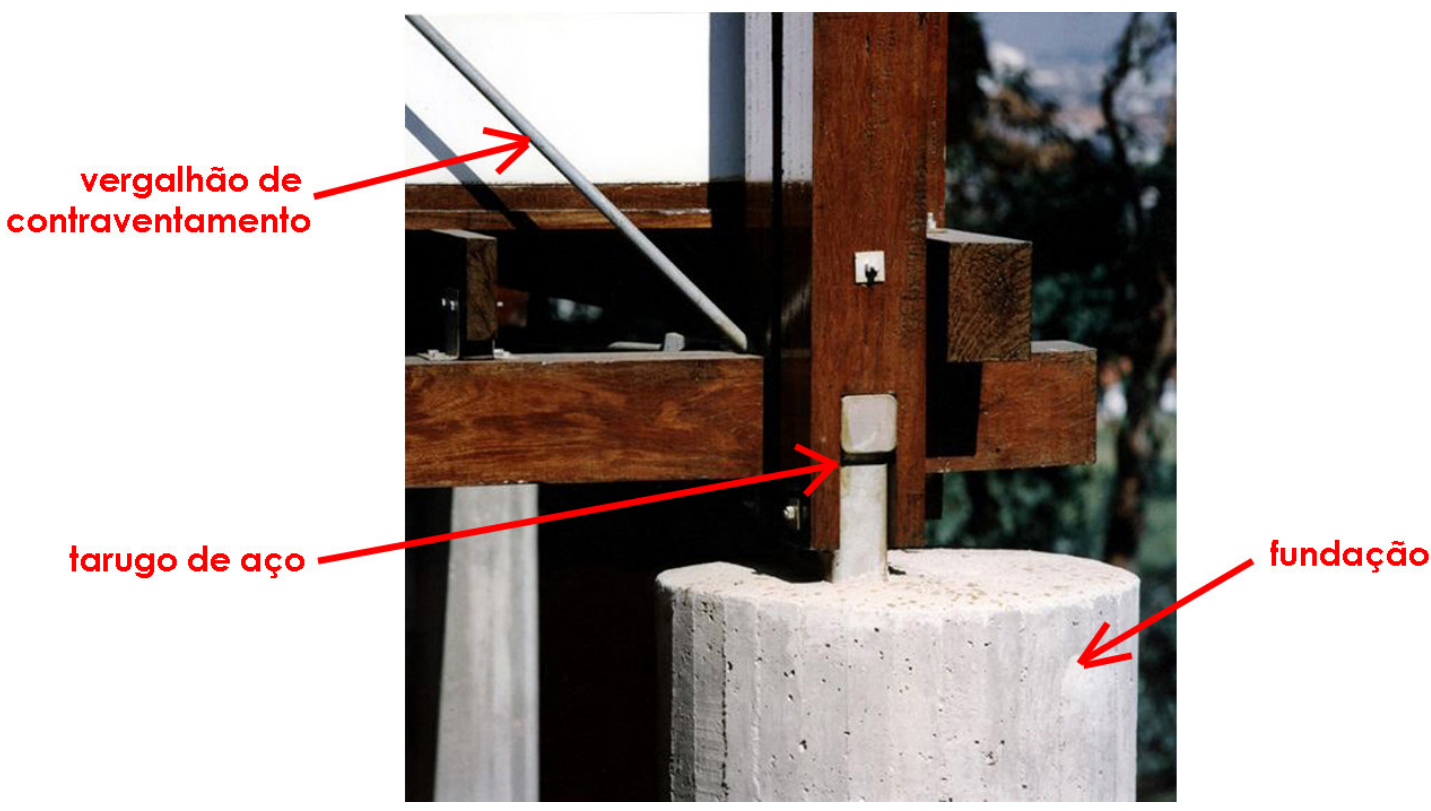

Fig. 6.25: Nó estrutural. Encontro: fundação, vigas e pilaretes de madeira e vergalhões de contraventamento. Tarugos de aço resistem melhor às forças de compressão muito intensas perpendiculares ao sentido das fibras. (fonte: arquivo pessoal Marcos Acayaba - editada pela autora)
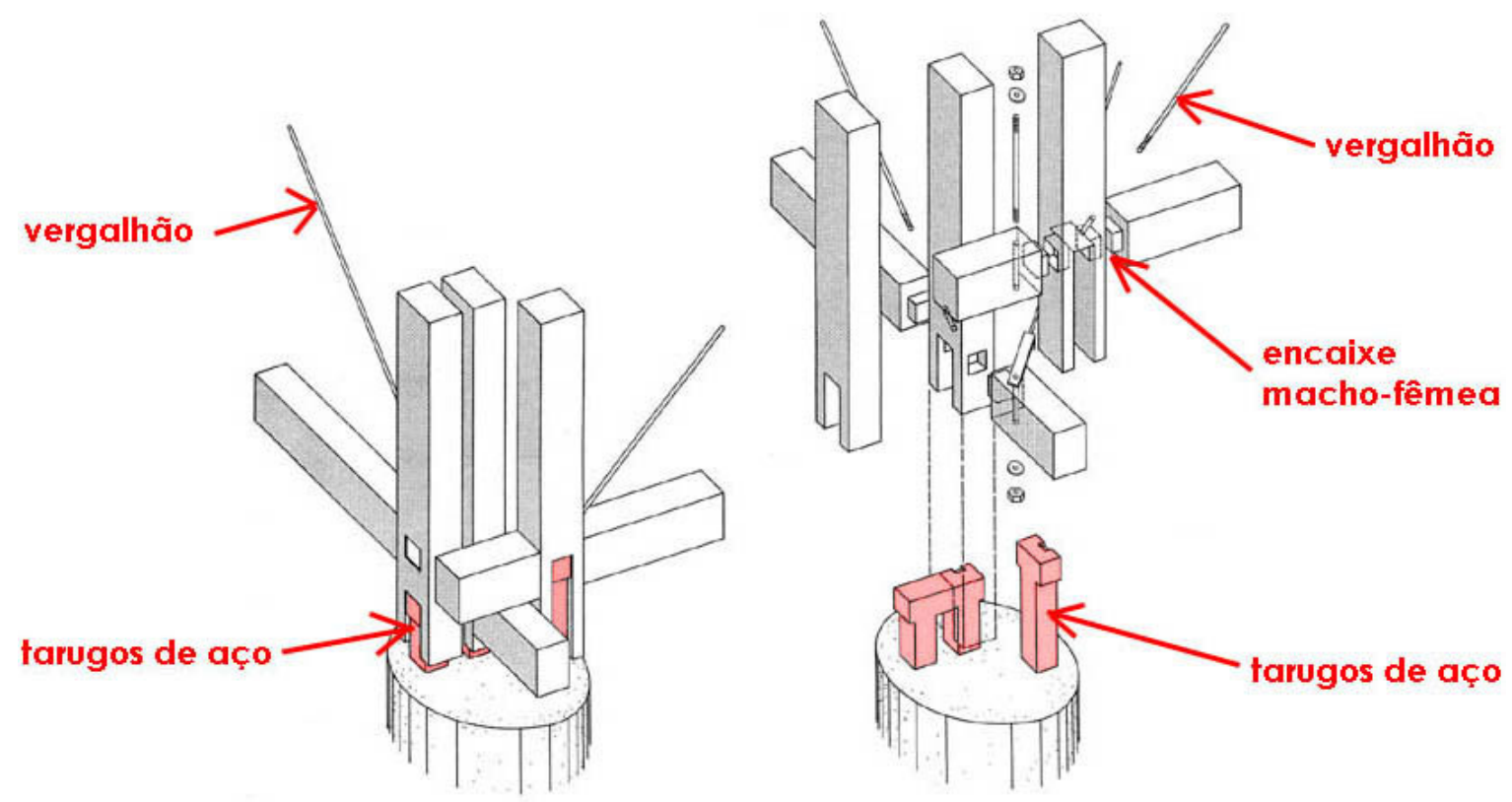

Fig. 6.26: Nó estrutural. Tarugos de aço fazem a transição entre a fundação e a estrutura de madeira. (fonte: arquivo pessoal Marcos Acayaba - editada pela autora) 


\section{Capítulo 6}

Residência Hélio Olga
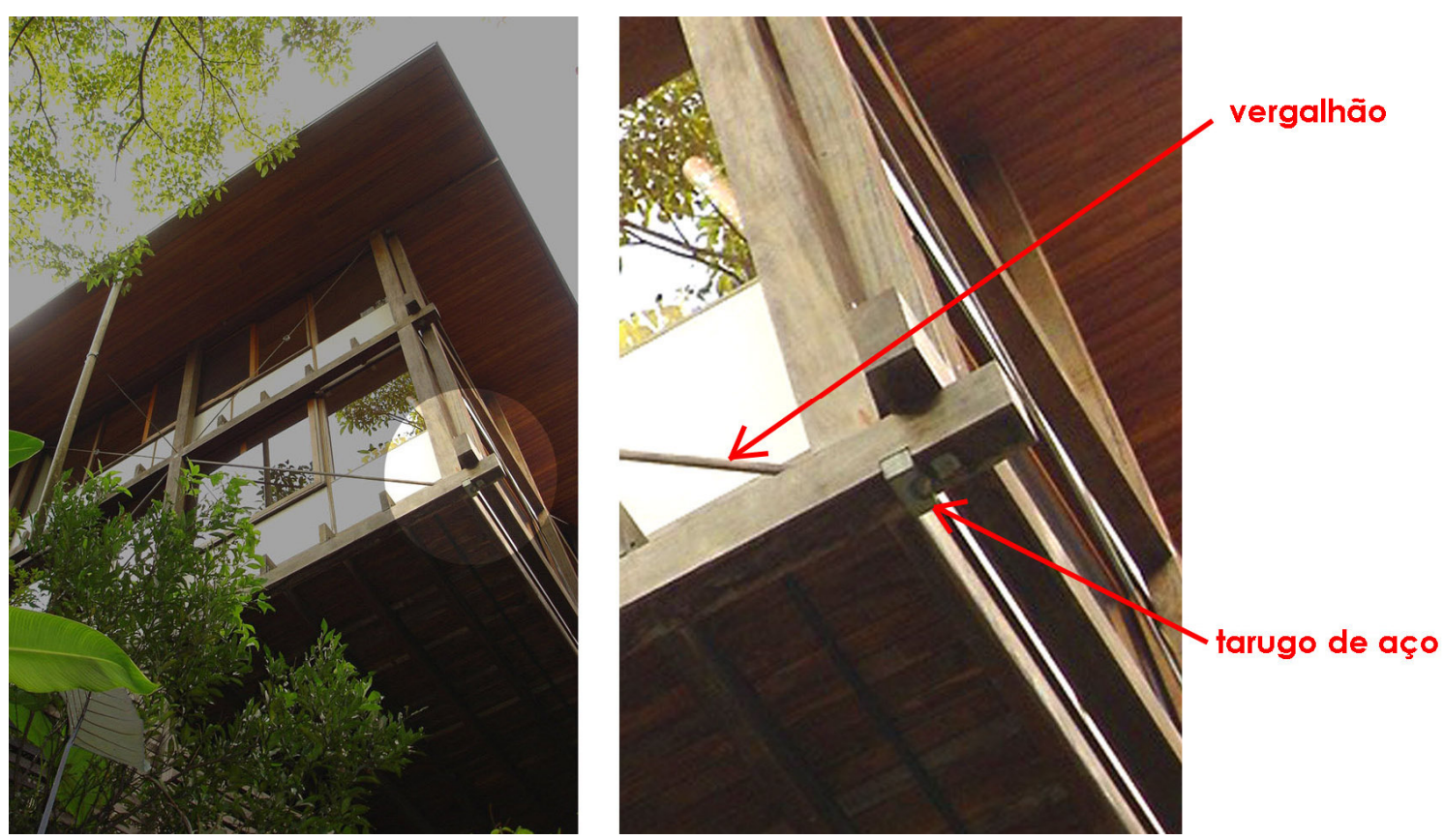

Fig. 6.27: Nó estrutural. Encontro de vigas, pilaretes e vergalhões em quina. (fonte: autora)
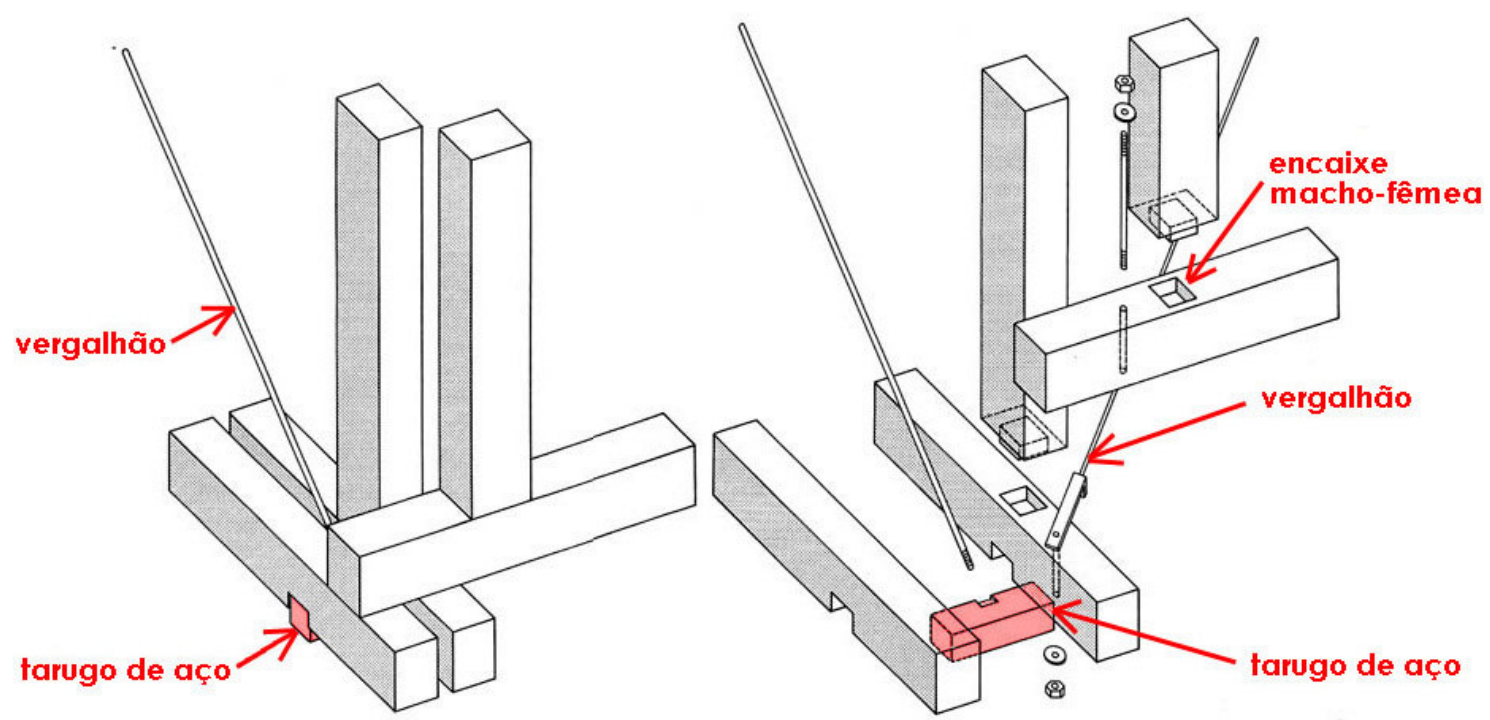

Fig. 6.28: Nó estrutural. Vergalhões de contaventamento são fixados ao tarugo de aço. (fonte: arquivo pessoal Marcos Acayaba - editada pela autora) 
Capítulo 6

Residência Hélio Olga
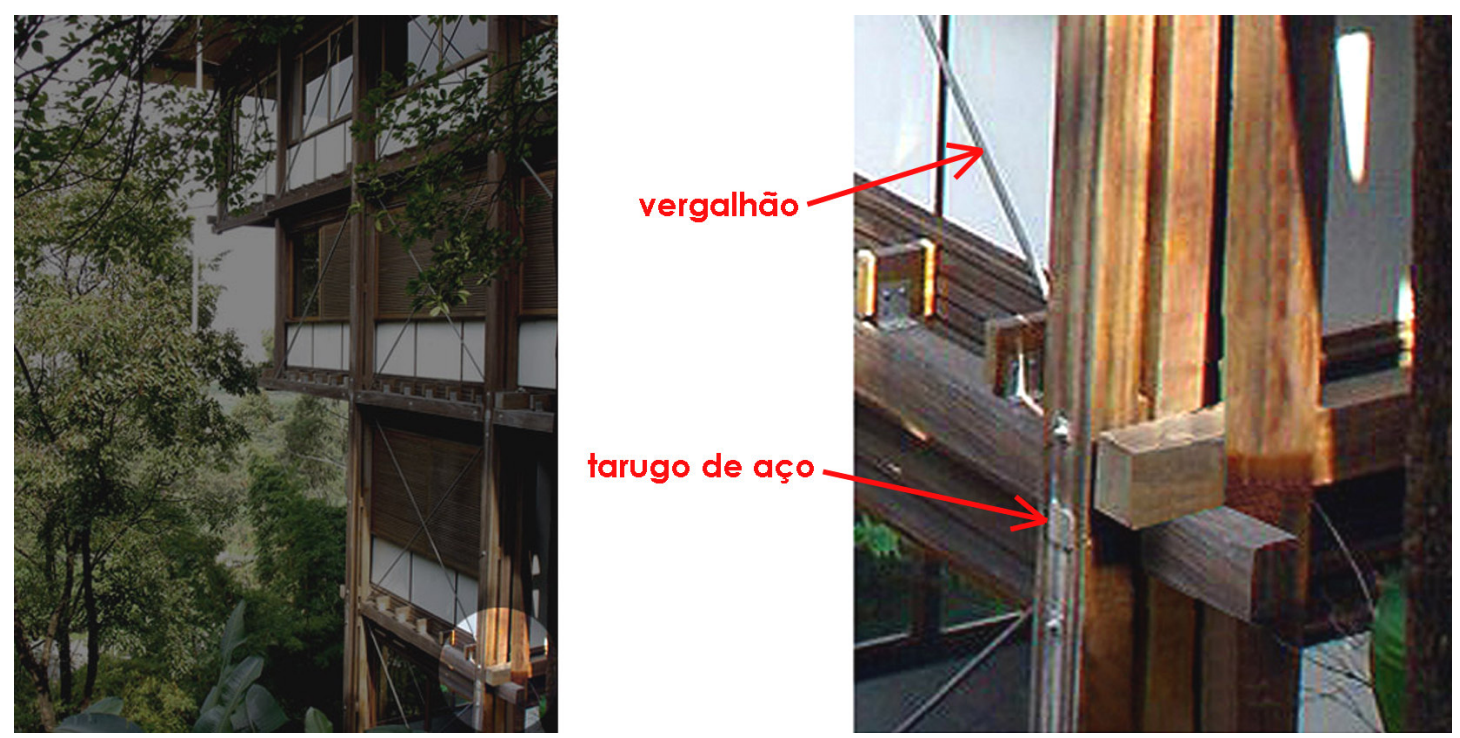

Fig. 6.29: Nó estrutural. Encontro de vigas, pilaretes e vergalhões. (fonte: autora)
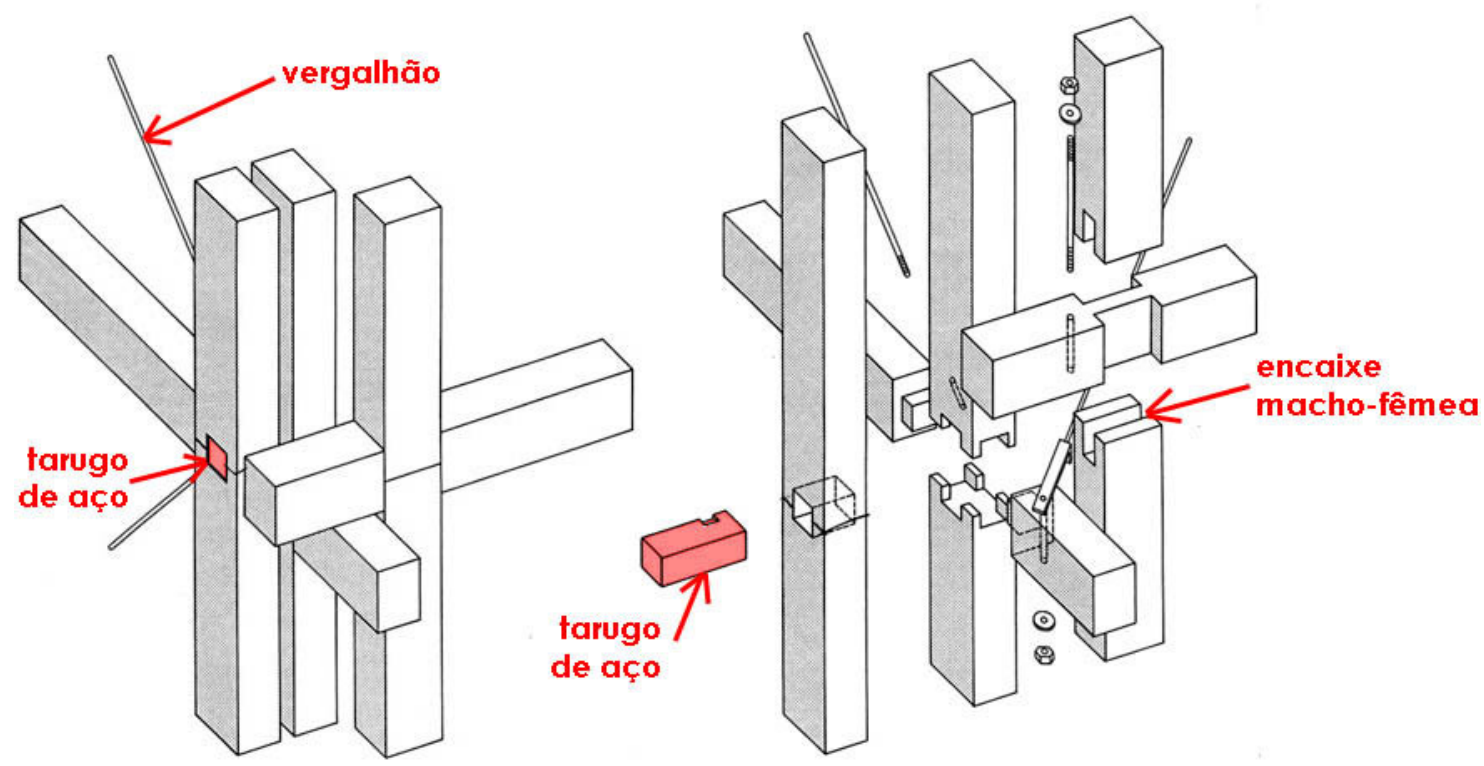

Fig. 6.30: Nó estrutural. Tarugo de aço resiste melhor às forças de compressão perpendiculares ao sentido das fibras e às forças de tração dos vergalhões de contraventamento. (fonte: arquivo pessoal Marcos Acayaba - editada pela autora) 


\section{Capítulo 6}

Residência Hélio Olga

A madeira utilizada na estrutura foi o Angelim Vermelho, uma madeira dura, de cor castanha avermelhada clara. Essa madeira possui aspecto fibroso e se apresenta resistente ao ataque de fungos e cupins (NOGUEIRA; NOGUEIRA, 2001).

O piso (assoalho de madeira sucupira sobre vigamento em angelim) funciona também como travamento horizontal da estrutura, transferindo as cargas dos pisos superiores para as vigas secundárias, evitando deformações de torção no conjunto, associado a vergalhões de aço tracionados.

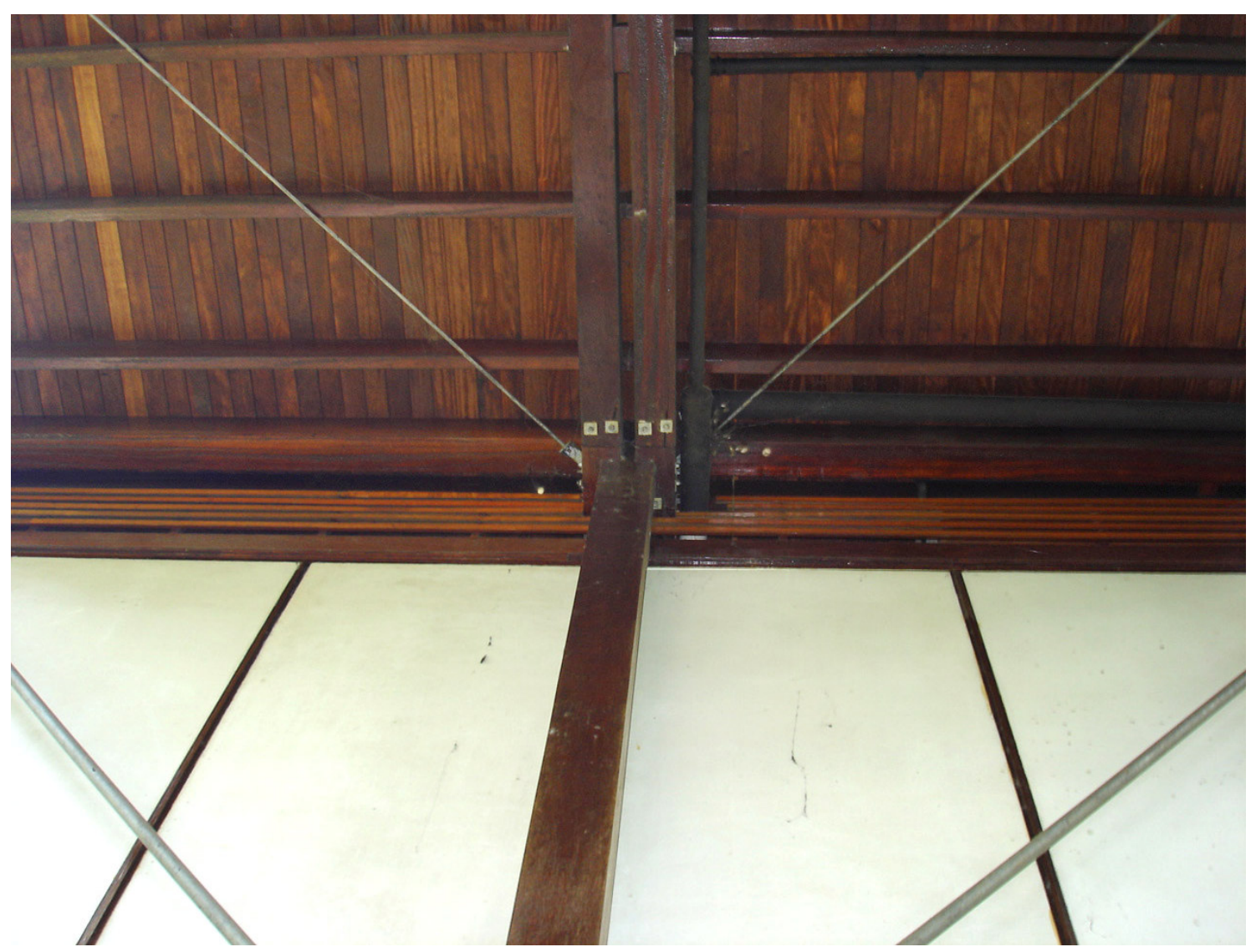

Fig. 6.31: Vista da parte inferior do balanço. Assoalho e vergalhões de travamento do pavimento dos dormitórios. Fechamento do shaft horizontal para passagem de instalações em ripas de madeira permite ventilação entre piso e forro. (fonte: autora)

As vedações são feitas em painéis compostos por sarrafos entre lâminas de madeira colados com resina fenólica, e chapas lisas cimentícias (cimento, celulose e fio sintético) nas faces externas. Esses painéis são popularmente 
Capítulo 6

Residência Hélio Olga

conhecidos como painel wall e fixados através de perfis metálicos parafusados na estrutura.

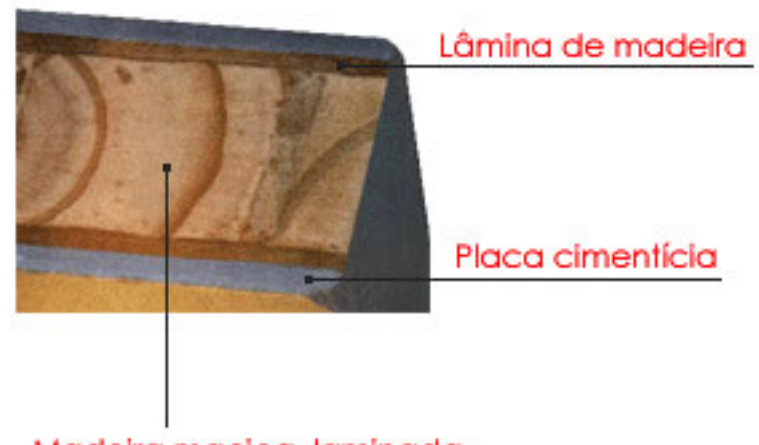

Madeira maciça, laminada ou sarrafeada

Fig. 6.32: Painel Wall. (fonte: PAINEL, 2007 editada pela autora)

O tipo de tecnologia utilizada nesse projeto prevê o início da "construção" longe do local da obra. Todas as peças são cortadas na serraria da construtora Ita, chegando ao local da obra prontas para serem montadas:

Quando baixam do escritório as fichas de serviço de um novo projeto, e as peças de jatobá e caramuru são transportadas para o galpão central, tem início a transformação. Primeiro, elas passam pela inspeção do engenheiro responsável que designa aos pilares, vigas e barrotes o papel preciso que cada um irá desempenhar. Em seguida, principiam as operações de aparelhamento (na desempenadeira e desengrossadeira), corte (na destopadeira), marcação (que, combinando a mecânica com o porrete e o formão, faz os furos e os rebaixos para o encaixe perfeito das ferragens), coloração de ferragens e proteção com seladora. Ao final dessas operações, que conforme as dimensões do projeto podem levar alguns dias ou várias semanas, cada peça de madeira está pronta para ser numerada, transportada até o local da obra, montada e então cumprir, de uma vez por todas, a sua exata função construtiva" (MARTINS, 2005, p.15).

O dimensionamento das peças é pensado levando em consideração transporte e montagem, por isso o arquiteto precisa ter muita atenção no planejamento dos espaços e dimensionamento dos vãos. A preocupação com as questões técnicas e tecnológicas deve, portanto, estar presente desde o início da concepção do projeto arquitetônico.

Segundo entrevista concedida por Hélio Olga (SOUZA JR., 2007a), os projetistas de instalações e projetos complementares em geral entram desde o começo 
do desenvolvimento do projeto. Assim que a estrutura atende a arquitetura, o projeto já é distribuído entre todos os outros projetistas, como de elétrica, hidráulica, concreto (fundações), ar condicionado, paisagismo etc.

Todo projeto, tanto de arquitetura quanto de projetos complementares, é amarrado no de estruturas de madeira, pelo menos deveria ser, porque a estrutura dá um rigor muito grande em termos de desenho [...] Quando você tiver uma modulação a cada cinqüenta, na hora de você botar uma luminária, alguma coisa, você vai estar sujeito a essa modulação (SOUZA JR., 2007a).

A interdisciplinaridade mostra-se muito presente. Os projetos de arquitetura, estrutura, elétrica e hidráulica têm que estar em diálogo constante entre si, e o desenvolvimento de cada um é intrinsecamente atrelado aos outros, exigindo dos profissionais um conhecimento básico dos fatores implicantes no seu desenvolvimento como, por exemplo, a modulação.

A utilização racional da madeira e seus produtos derivados na
construção torna necessária a adoção de critérios dimensionais
que façam seu uso eficiente desde as etapas de extração e
transformação para, por fim, facilitar o projeto, a fabricação e a
construção. Isso se alcança com o Sistema de Coordenação
Modular que tem como objetivo relacionar as dimensões dos
ambientes arquitetônicos, reduzir o desperdício, aumentar o
rendimento da mão de obra e diminuir o tempo de construção
(JARA; MENDOZA, 1984, p.4-13, grifo nosso) A coordenação modular exige do arquiteto uma atenção especial às questões técnicas ligadas à obra. É uma "[...] técnica que permite definir e racionalizar dimensões de materiais e componentes em projeto e obra, através de medidas modulares organizadas por meio de um reticulado espacial de referência" (LUCINI, 2001, p.23).

O sistema modular pré-fabricado possibilita uma produção seriada, adequando o sistema a outras necessidades de implantação. Segundo Jara e Mendoza (1984), esse sistema, quando utilizado em casas projetadas de forma individual, não costuma ser econômico devido à grande quantidade de detalhes necessários para especificar cortes e encaixes de peças e à dificuldade para não confundir as peças antes e durante a montagem. 
Capítulo 6

Residência Hélio Olga

Nesse caso, pelo fato de Hélio ser ao mesmo tempo proprietário, projetista e construtor, além de resultar econômica, essa solução desenvolveu-se como uma atividade de investigação e pesquisa. 


\subsection{Considerações sobre o projeto}

Segundo Olga, o terreno foi adquirido por um valor muito baixo, pois o proprietário anterior havia começado a construir, utilizando um sistema convencional, mas com todas as dificuldades ocorridas durante o canteiro, foi desencorajado a seguir com a obra. Essa situação soou como um desafio, pois ele, como construtor, já intuía que o sistema pré-fabricado em madeira poderia ser uma boa solução em relação à dinâmica de canteiro (informação verbal) ${ }^{2}$.

A partir dessas premissas é que Acayaba passou a fazer parte do desenvolvimento da solução. Era preciso criar um sistema que se adequasse àquelas condições que o terreno impunha e que, ao mesmo, cumprisse com as definições do programa e as condições de conforto térmico.

Em função dessas necessidades, o arquiteto demonstrou um bom domínio técnico ao desenvolver todo o esquema espacial e estrutural da casa, encontrando um consenso entre programa e estrutura, trazendo para Hélio, questões de dimensionamento e montagem das peças.

Após a construção dessa casa, o sistema, que apresenta potencialidades para a produção seriada, foi novamente utilizado até o momento, somente na construção do escritório de Hélio (ao lado de sua casa), mas tem sido referência para o desenvolvimento de novas soluções construtivas em madeira desenvolvidas por Acayaba e Hélio, como as casas de estrutura em madeira pré-fabricada, no sistema de base triangular, analisadas no capítulo seguinte.

\footnotetext{
2 Informação dada por Olga em palestra ministrada em 2003, na Escola de Engenharia de São
} Carlos da Universidade de São Paulo. 


\section{Capítulo 6}

Residência Hélio Olga

\subsection{Ficha técnica - Residência Hélio Olga}

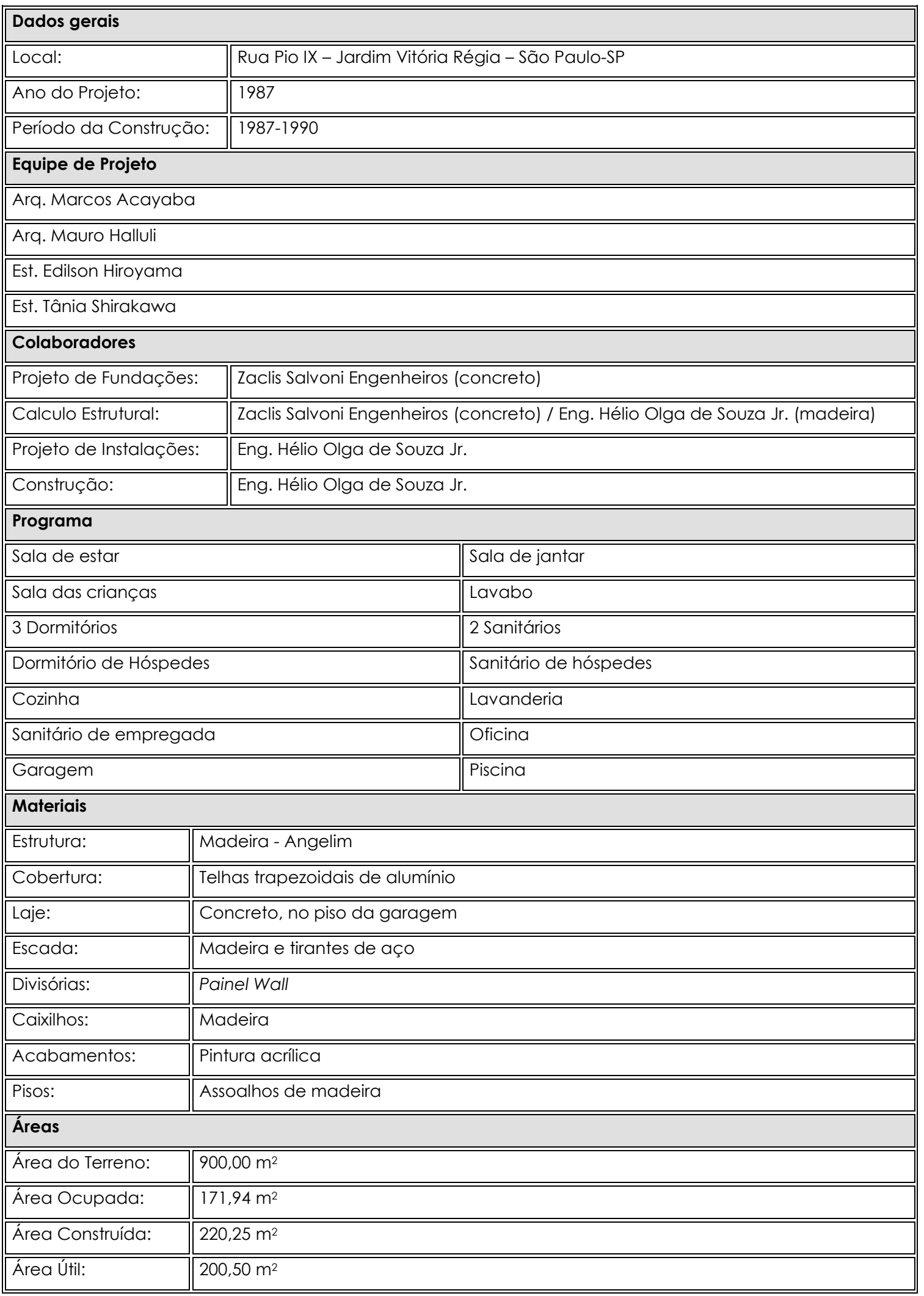




\title{
CAPÍTULO 7:
}

\author{
RESIDÊNCIA BAETA (Guarujá - SP, 1993-1994)
}

\section{RESIDÊNCIA MARCOS ACAYABA (Guarujá - SP, 1996-1997)}

Fig. 7.1: Residência Baeta. (fonte: arquivo pessoal Marcos Acayaba)
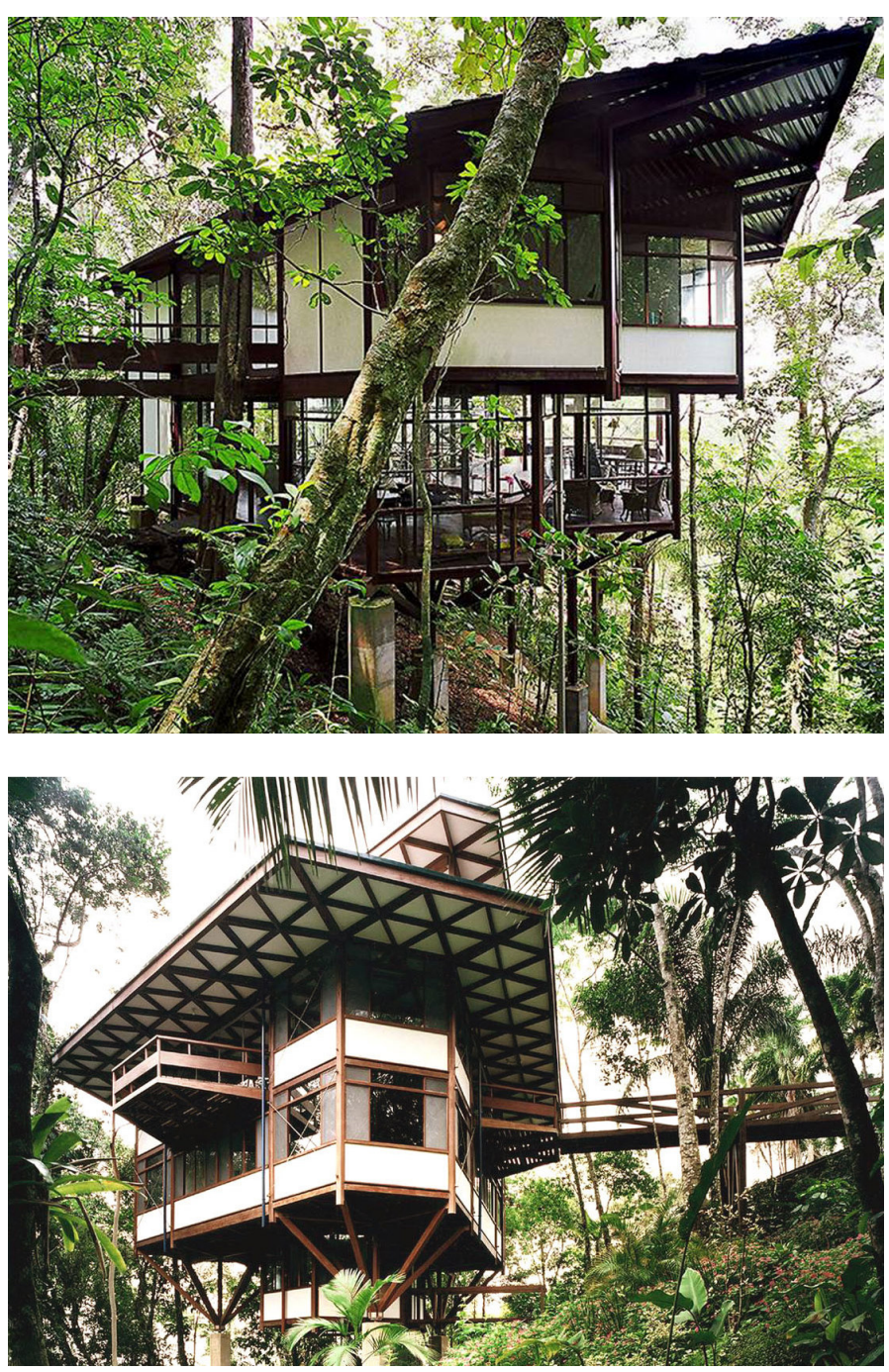

Fig. 7.2: Residência Marcos Acayaba. (fonte: arquivo pessoal Marcos Acayaba)

Nota: Nesse capítulo, alguns detalhes construtivos são específicos de cada residência. Para evitar dificuldade de entendimento, eles são descritos no item específico "O projeto", do qual fazem parte. 


\section{Capítulo 7}

Residência Baeta e Residência Marcos Acayaba

\subsection{O projeto}

\section{Residência Baeta}

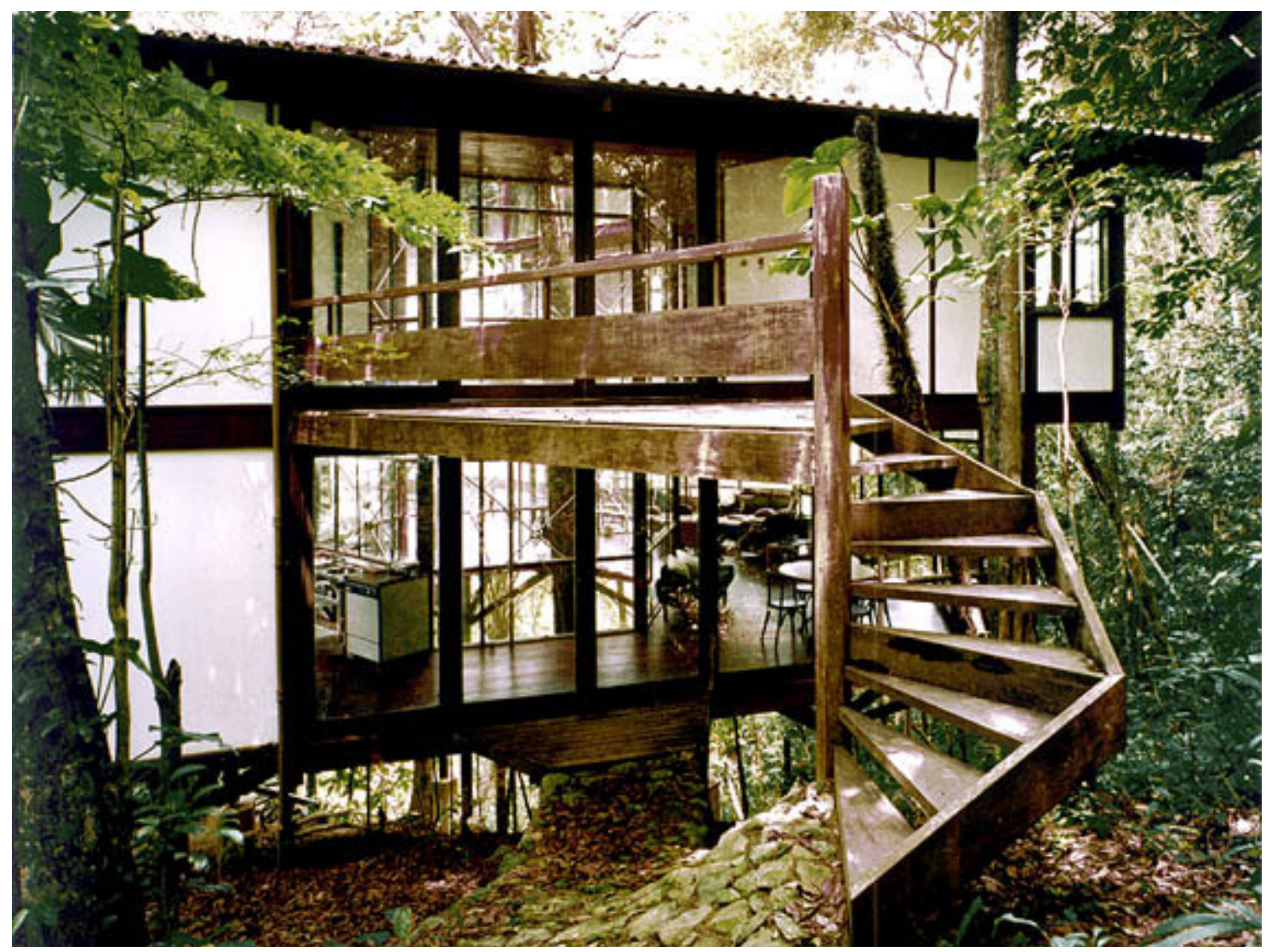

Fig. 7.3: Residência Baeta. Escada do fundo. (fonte: arquivo pessoal Marcos Acayaba)

No projeto da residência Baeta, realizado também em parceria com o engenheiro Hélio Olga, Acayaba adota uma postura preocupada com questões ambientais e ecológicas, recorrentes principalmente a partir da década de 80. O respeito pelo contexto e pelo meio físico determina todo o projeto da casa, desde o modo de implantação até a tecnologia utilizada.

Devido à localização em terreno acidentado e em meio à mata nativa, a casa mantém-se elevada em relação ao solo, permitindo que a vegetação local fosse preservada e que a água da chuva continuasse escoando normalmente. 


\section{Capítulo 7}

Residência Baeta e Residência Marcos Acayaba

Esse terreno, assim como na residência Hélio Olga, também não permitia um canteiro de obras convencional, devido à sua declividade acentuada e à mata, então se desenvolveu um sistema construtivo pré-fabricado em madeira que permitiu que a casa fosse erguida em 40 dias, por apenas três homens.

As peças foram todas produzidas na serraria e montadas no canteiro e, por serem todas de pequenas dimensões, não houve a necessidade de se utilizar equipamentos pesados.

A estrutura modular obedece a princípios de triangulação, dispensando o uso de travamentos horizontais e permitindo que todos os ambientes tenham vista para o mar, além de facilitar a implantação em meio às arvores já existentes no local.

Os dois pavimentos da casa se apóiam nas mãos francesas que saem do total de seis pilares de apoio, os quais transmitem as cargas à fundação de tubulões.

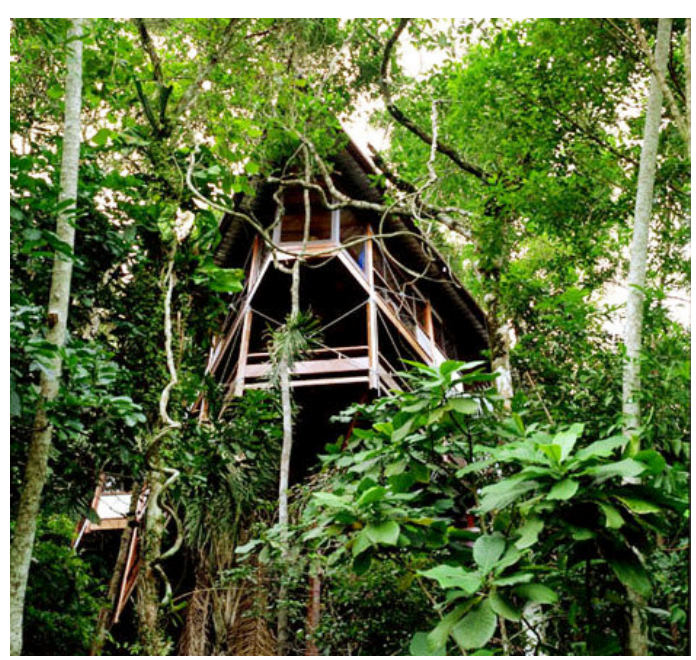

Fig. 7.4: Vista da trilha de acesso à residência. (fonte: arquivo pessoal Marcos Acayaba)

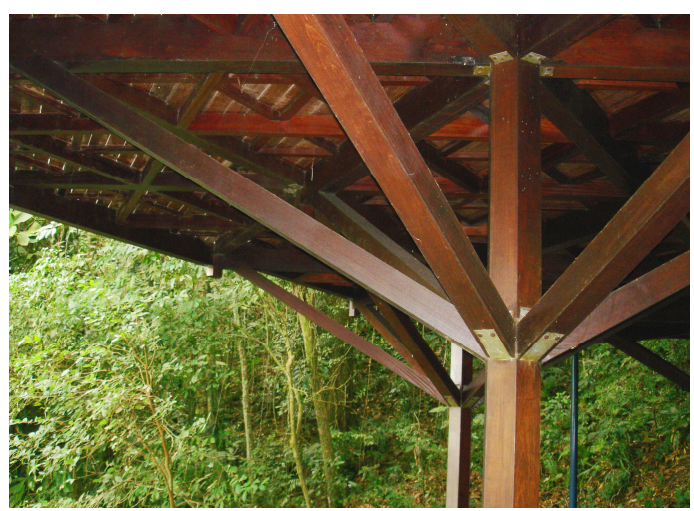

Fig. 7.5: Mãos francesas. (fonte: autora) 


\section{Capítulo 7}

Residência Baeta e Residência Marcos Acayaba

No centro da casa abre-se um pátio hexagonal, preservando duas árvores já existentes no terreno, facilitando a ventilação e a iluminação natural. Serve também como travamento vertical do edifício, resistindo aos esforços horizontais e à ação dos ventos (os seis planos verticais que compõem o pátio são atirantados).
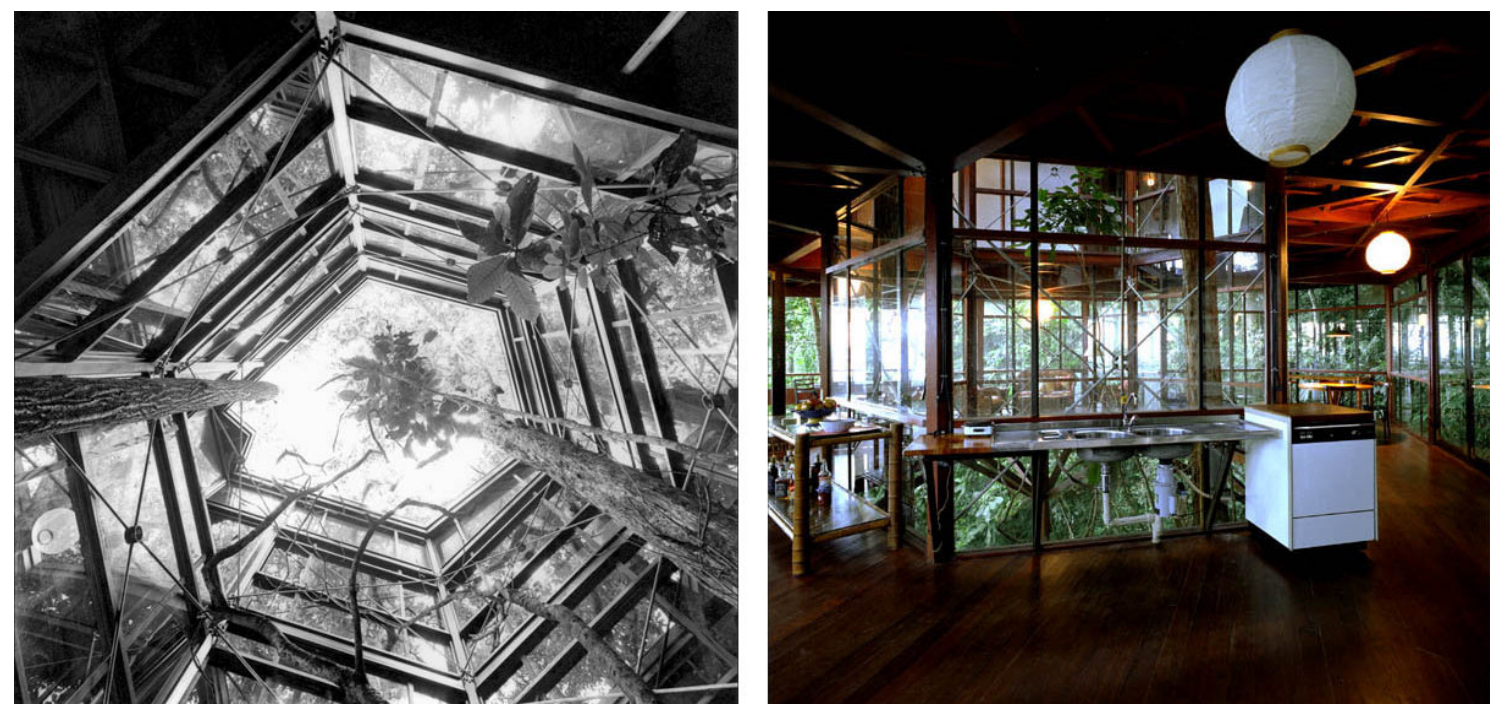

Fig. 7.6: Pátio central. Travamento vertical, ventilação e iluminação. (fonte: arquivo pessoal Marcos Acayaba)

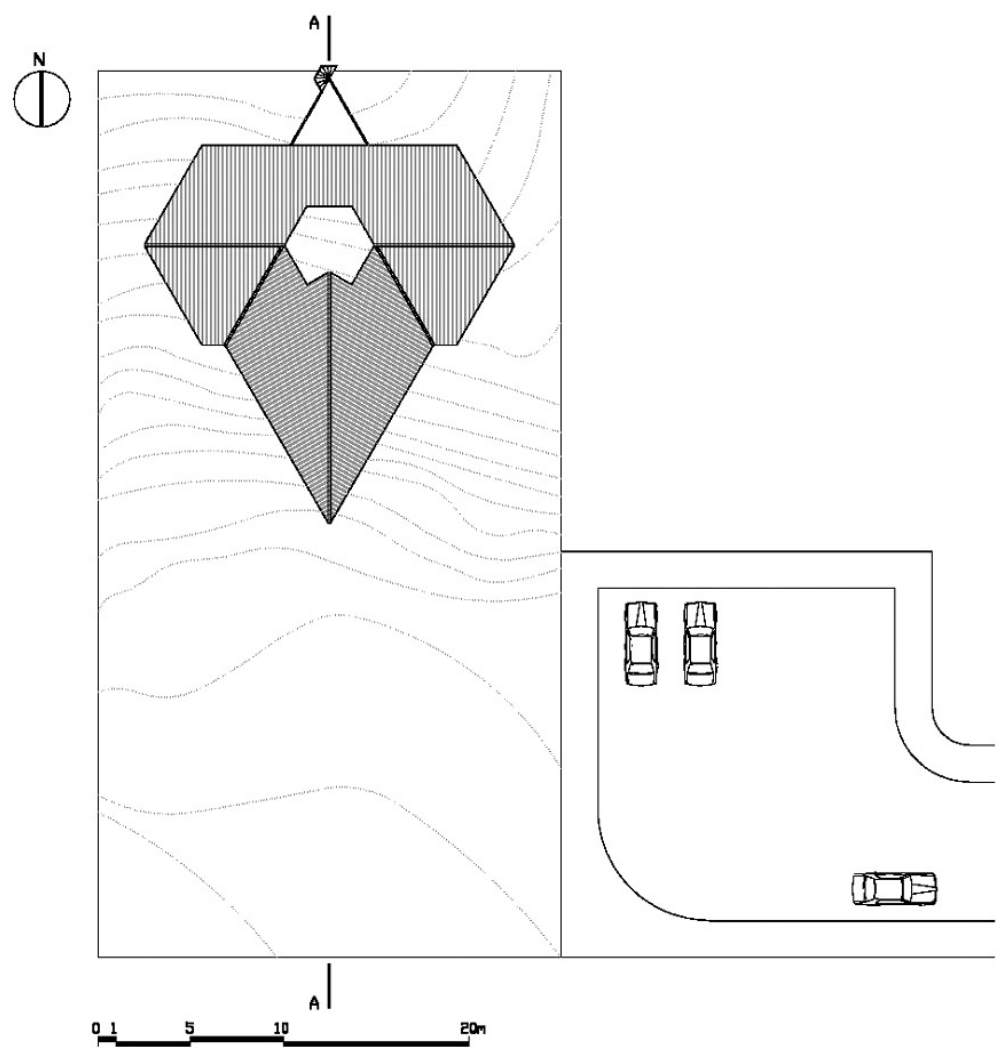

Fig. 7.7: Implantação. (fonte: arquivo pessoal Marcos Acayaba) 


\section{Capítulo 7}

Residência Baeta e Residência Marcos Acayaba
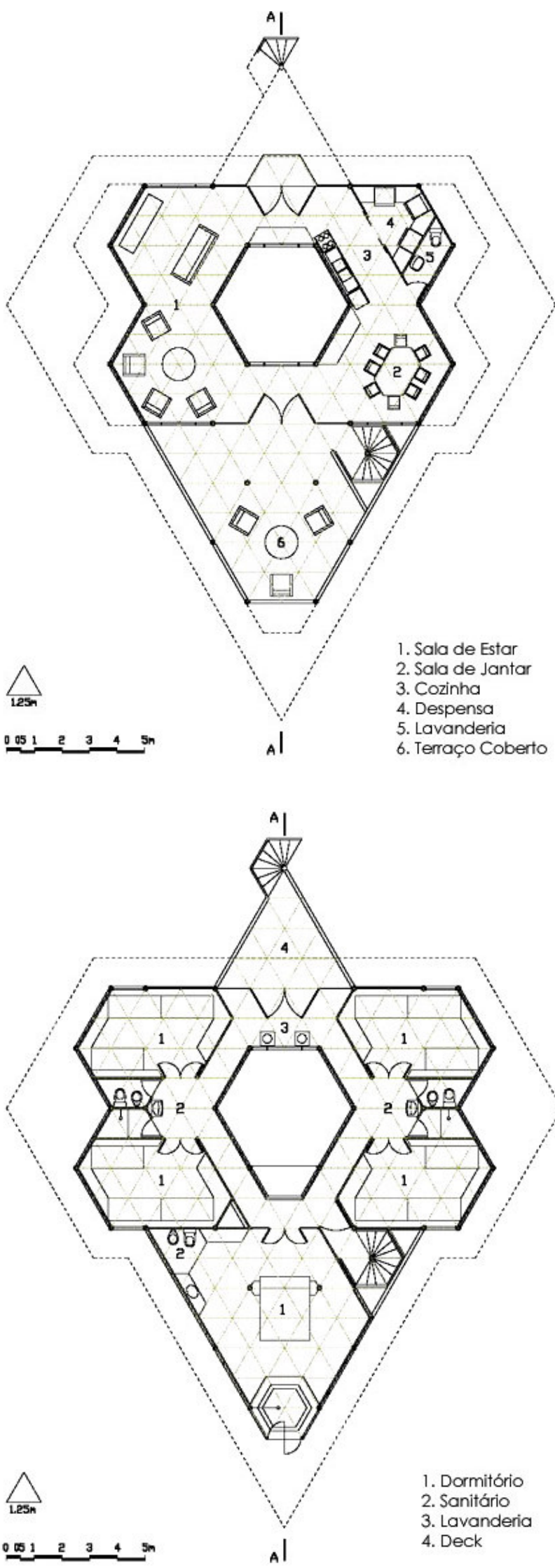

Fig. 7.8: Planta nível inferior. Nível de acesso. (fonte: arquivo pessoal Marcos Acayaba)
Fig. 7.9: Planta nível superior. Nível dos dormitórios. (fonte: arquivo pessoal Marcos Acayaba) 


\section{Capítulo 7}

Residência Baeta e Residência Marcos Acayaba

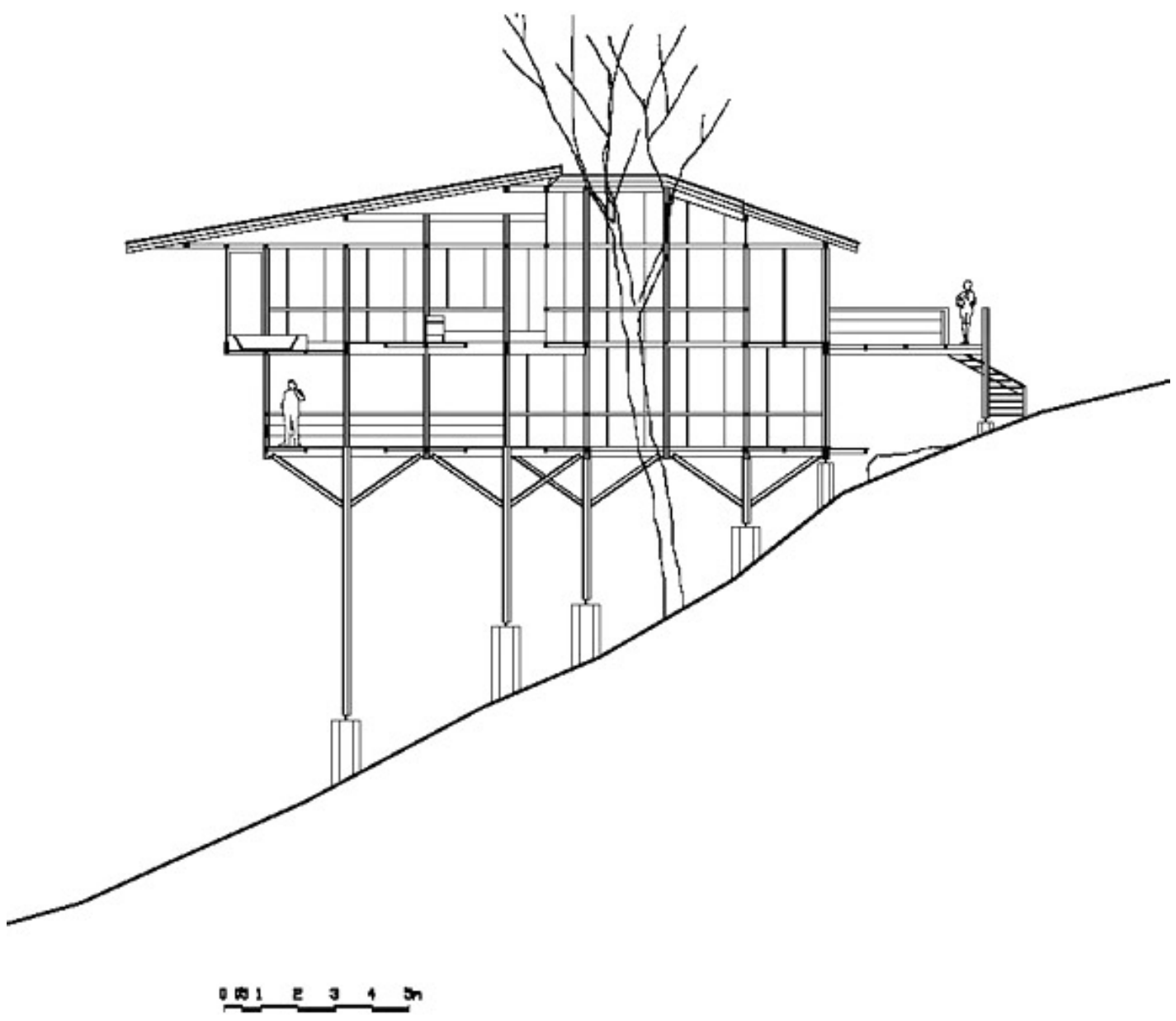

Fig. 7.10: Corte. (fonte: arquivo pessoal Marcos Acayaba)

Para a vedação foram utilizados painéis industrializados, de $40 \mathrm{~mm}$ de espessura, compostos por sarrafos entre lâminas de madeira e chapas cimentícias, conhecidas como painéis wall (Ver capítulo 6, p. 100).

Na cobertura, foi empregada telha trapezoidal de alumínio que, assim como o material utilizado nas vedações, é uma solução leve, que diminui o peso próprio do edifício, aliviando a carga sobre a estrutura.

Nos sanitários, o piso é elevado e revestido por um tipo de plástico reforçado com fibra de vidro (fiber-glass). Esse mesmo material também reveste as paredes dos boxes, criando uma grossa camada de proteção contra a umidade. 


\section{Capítulo 7}

Residência Baeta e Residência Marcos Acayaba
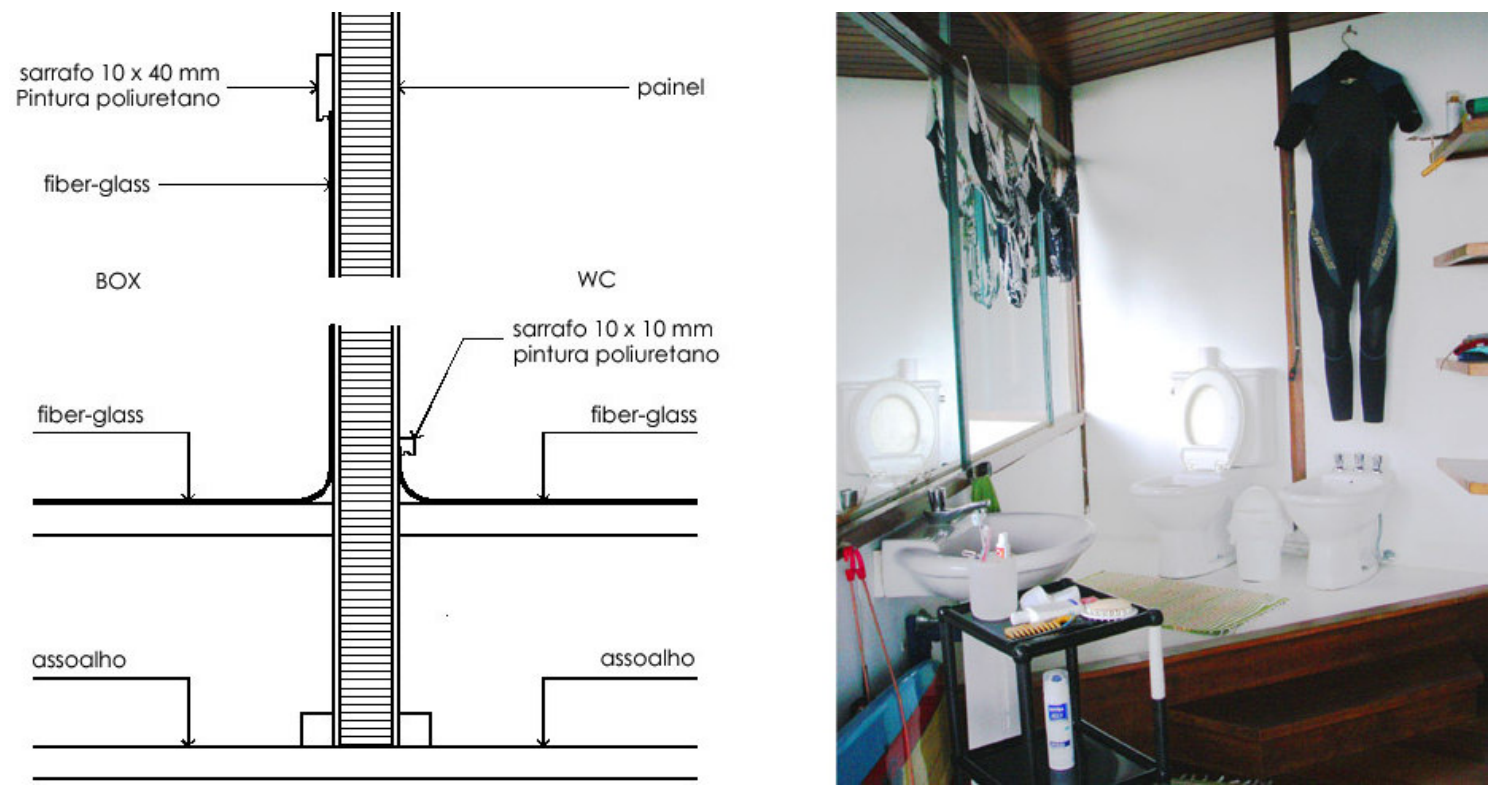

Fig. 7.11: Detalhe em corte do revestimento dos sanitários e foto do sanitário do casal, aberto para o quarto. (fonte: à esquerda, arquivo pessoal Marcos Acayaba e à direita, autora)

No início da concepção do projeto, os caixilhos seriam feitos de maneira convencional, com trilhos e folhas emolduradas em madeira, mas no desenvolvimento do projeto, percebeu-se, segundo Acayaba (2004), que essa solução aumentaria muito o custo da obra (superior a $25 \%$ do valor total da estrutura), e sua execução seria trabalhosa e demorada.

Mesmo já estando com todos os desenhos de caixilharia prontos e detalhados, - arquiteto decidiu adotar uma solução mais simples e econômica, que facilitou a execução e também a manutenção do sistema de aberturas.

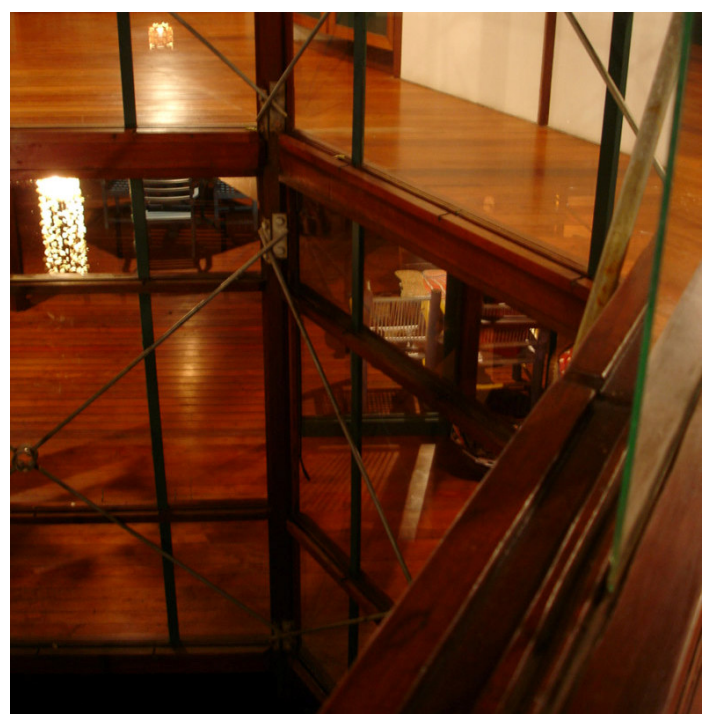

Fig. 7.12: Detalhe caixilho. (fonte: autora) 


\section{Capítulo 7}

Residência Baeta e Residência Marcos Acayaba

Algumas folhas são fixas, outras de correr, e constituem-se de lâminas de vidro temperado que correm cruas (não são montadas em esquadrias), por entre baguetes fixos ao peitoril de madeira, podendo, ou não, contar com telas de proteção contra insetos.

Apesar de um pouco pesada para sua manipulação, essas soluções se mostraram realmente eficazes como sistema de vedação.

Numa simplificação funcional do objeto 'esquadria', obteve-se o resultado prático esperado. Mantiveram-se da mesma forma todas as suas funções de vedação, ventilação e iluminação, além de ter seu custo reduzido.
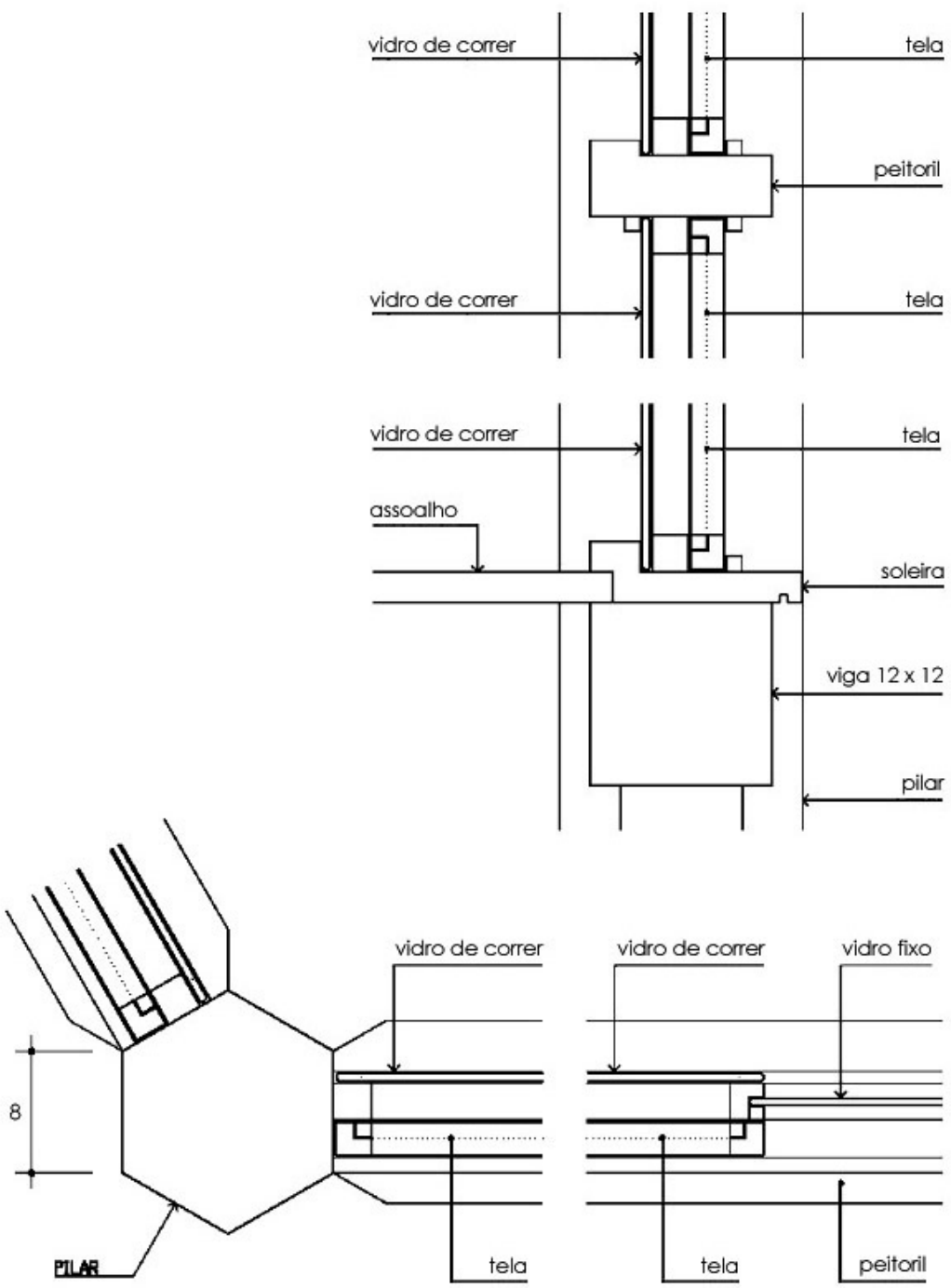

Fig. 7.13: Detalhamento do caixilho em corte e planta. (fonte: arquivo pessoal Marcos Acayaba editada pela autora) 


\section{Capítulo 7}

Residência Baeta e Residência Marcos Acayaba

Nesse projeto, mostra-se determinante a experiência adquirida na residência Hélio Olga, no âmbito do desenvolvimento do sistema construtivo. Uma das premissas que o diferenciava do projeto de Hélio era a existência de muitas árvores nativas no local de implantação. A idéia era não derrubar nenhuma delas, o que exigia uma implantação mais flexível possível. Por isso, decidiu-se adotar um sistema de triangulação, que não só facilitava a implantação, mas também se resolvia melhor na questão do travamento horizontal e do esquadrejamento no momento da construção.

Essa nova solução estrutural conferiu ao edifício uma linguagem muito particular. A partir de uma solução técnica, determinada pelas necessidades físicas do local, criou-se uma linguagem arquitetônica diferenciada, que define o edifício construtivamente e espacialmente, na medida em que o insere ao meio natural, propiciando a configuração de espaços integrados à natureza e com vistas para o mar, como desejavam os clientes.
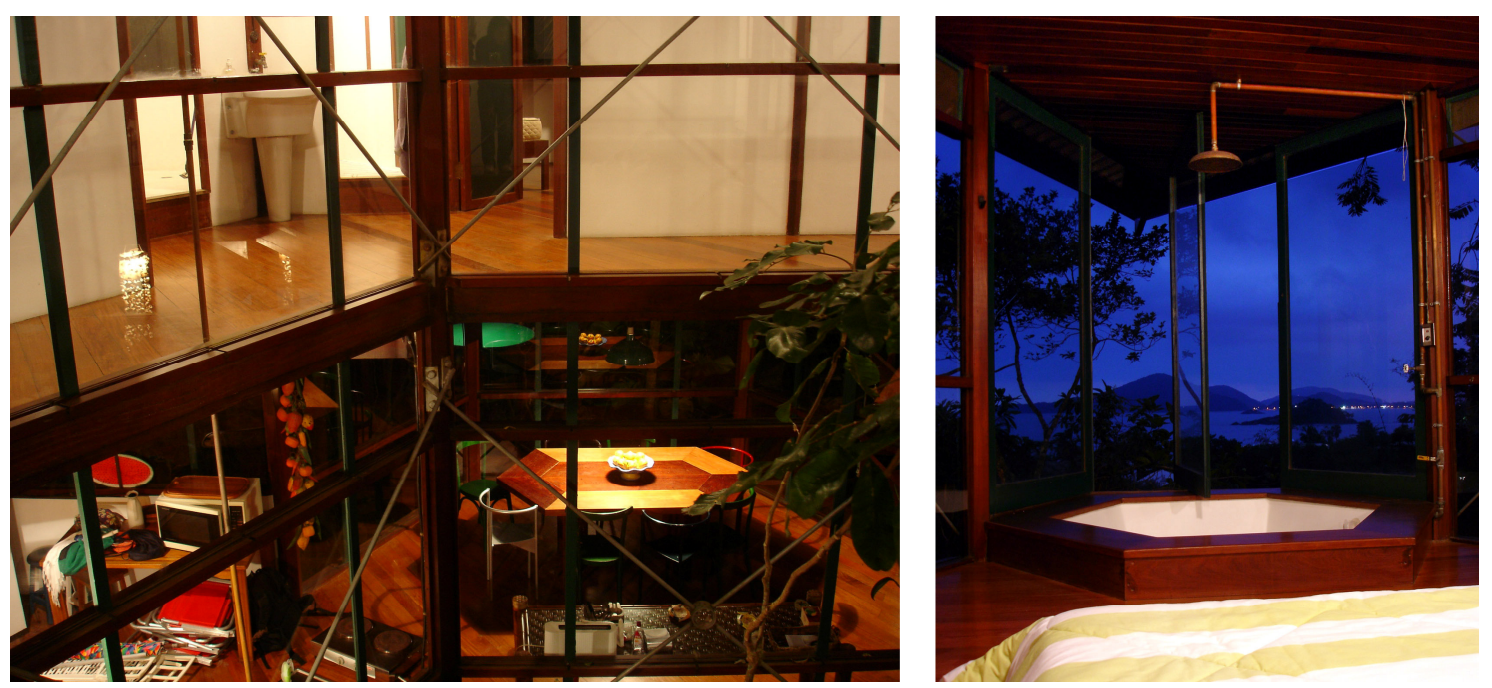

Fig. 7.14: Pelo vão central cercado de vidro é possível ver o interior da casa como um todo. A casa é cercada pela paisagem. (fonte: autora) 


\section{Capítulo 7}

Residência Baeta e Residência Marcos Acayaba

\subsection{O projeto}

\section{Residência Marcos Acayaba}

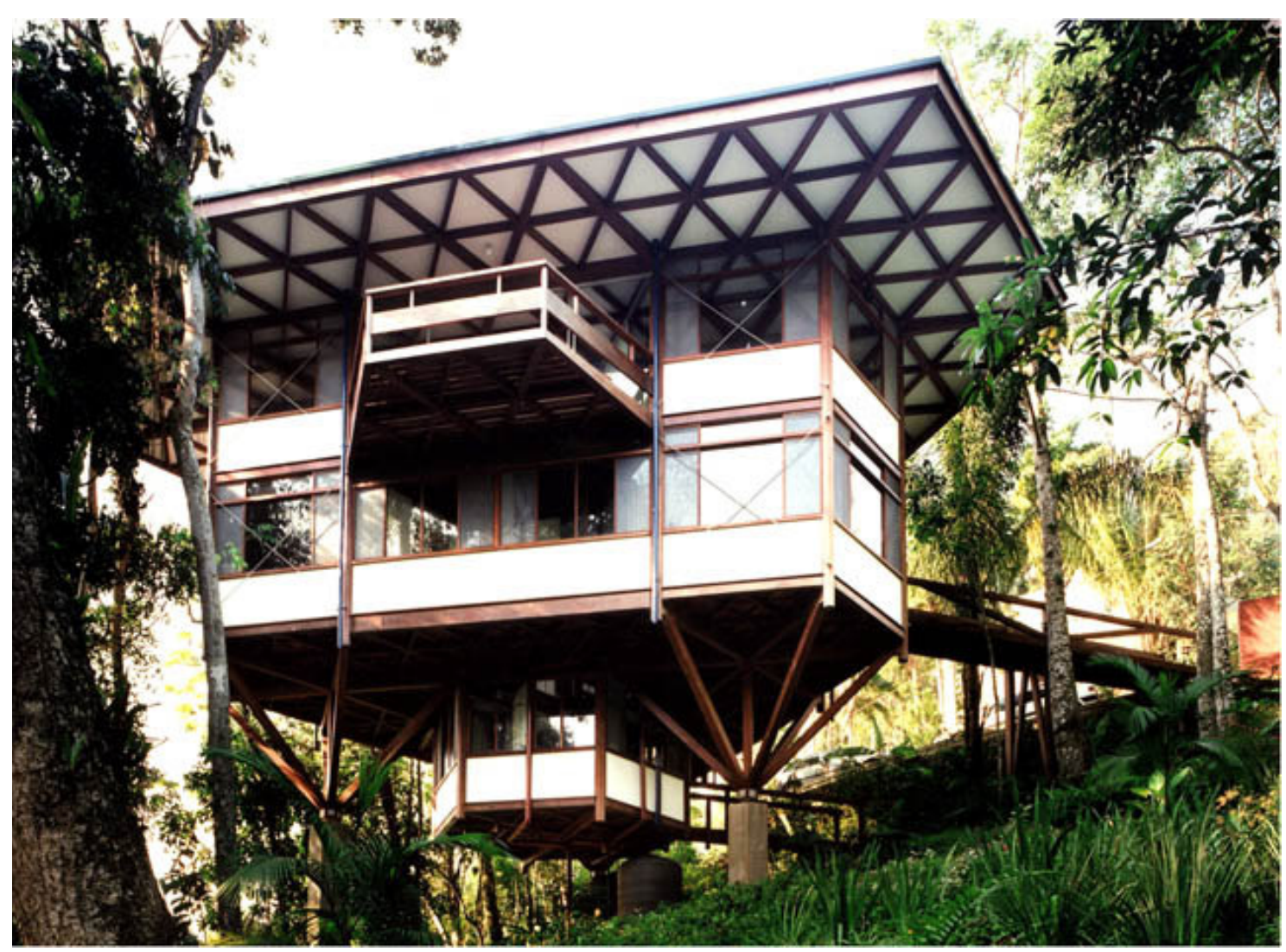

Fig. 7.15: Residência Marcos Acayaba. (fonte: arquivo pessoal Marcos Acayaba)

Essa casa surgiu da experiência adquirida no desenvolvimento ao longo de dez anos, de casas implantadas em terrenos de alta declividade, com vegetação a ser preservada e umidade intensa. A primeira delas foi a residência Hélio Olga, seguida de outras como, as residências Baeta e Valentim, essa também em modulação triangular.

Trata-se de um projeto de grande liberdade formal e construtiva, pois nesse caso o usuário é a própria família do arquiteto: o casal e duas filhas, na época, uma de 18 e uma de 23 anos, além de eventuais convidados. 
Segundo Acayaba (2004), a casa deveria ter manutenção simples, que dispensasse empregados fixos e acompanhamento muito constante. Os ambientes deveriam ser amplos e arejados, privilegiando ao máximo a vista para o mar e a integração com a natureza.

Nessa obra, as figuras do usuário, do arquiteto e do cliente se fundem numa só pessoa. Quando se projeta algo para uso próprio, há maior liberdade no planejamento do programa, nos prazos e na administração financeira. Isso permite uma maior liberdade de experimentação no desenvolvimento do projeto e das técnicas de construção.

Acayaba afirma que o programa de uma casa, pela sua simplicidade, proporciona ao arquiteto certa liberdade ao ato de projetar. A familiaridade com os ambientes e com as necessidades básicas do espaço de morar propicia maior desenvoltura ao definir suas formas e dimensões (informação verbal) ${ }^{1}$.

Para desenvolver esse projeto, um dos principais fatores determinantes foi o local de implantação. O terreno localiza-se na Serra do Guararú, no Guarujá, em meio a uma encosta com mata nativa a 150 metros do mar e a 80 metros de altitude. O clima é quente e úmido, típico das regiões litorâneas brasileiras, e caracteriza a vegetação, predominante de mata atlântica.

Os espaços distribuem-se em quatro pavimentos. O acesso se dá pelo terceiro, através de uma passarela (posteriormente coberta) no nível da sala e da cozinha, onde também há três terraços em balanço. Abaixo é o nível das suítes e a cima o terraço, que conta com uma área de churrasqueira e uma bela vista do mar. O pavimento inferior, abaixo das suítes, abriga dormitório, lavanderia e sanitário de empregada.

A escada caracol, que interliga os quatro pavimentos, é sustentada por um pilar central de madeira e por cabos de aço, que servem ao mesmo tempo como guarda corpo.

\footnotetext{
1 Informação dada por Acayaba em visita a seu estúdio de criação.
} 


\section{Capítulo 7}

Residência Baeta e Residência Marcos Acayaba
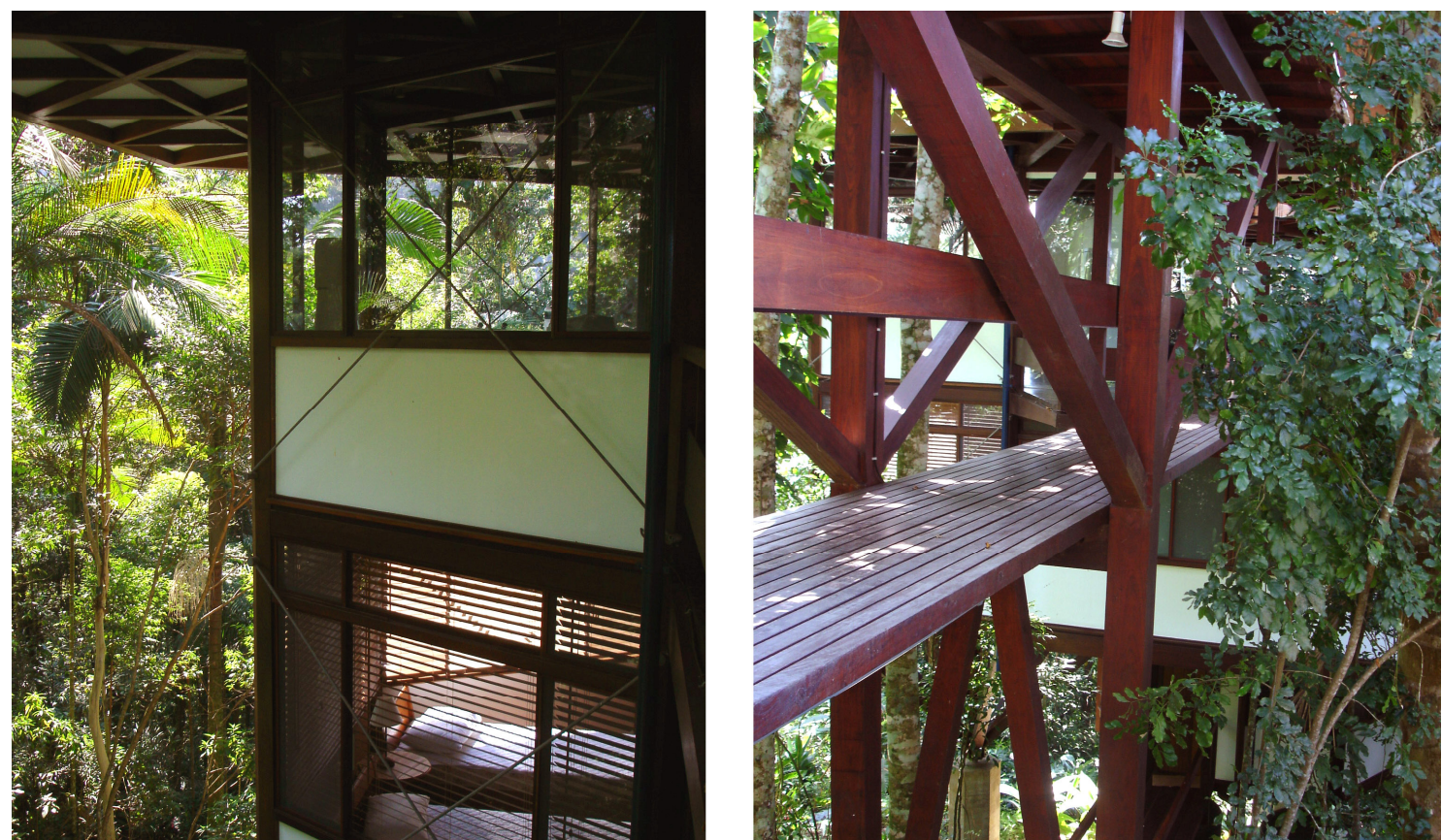

Fig. 7.16: Inserção em meio à vegetação nativa; cozinha acima e dormitório abaixo. Nova passarela de acesso, coberta. (fonte: autora)
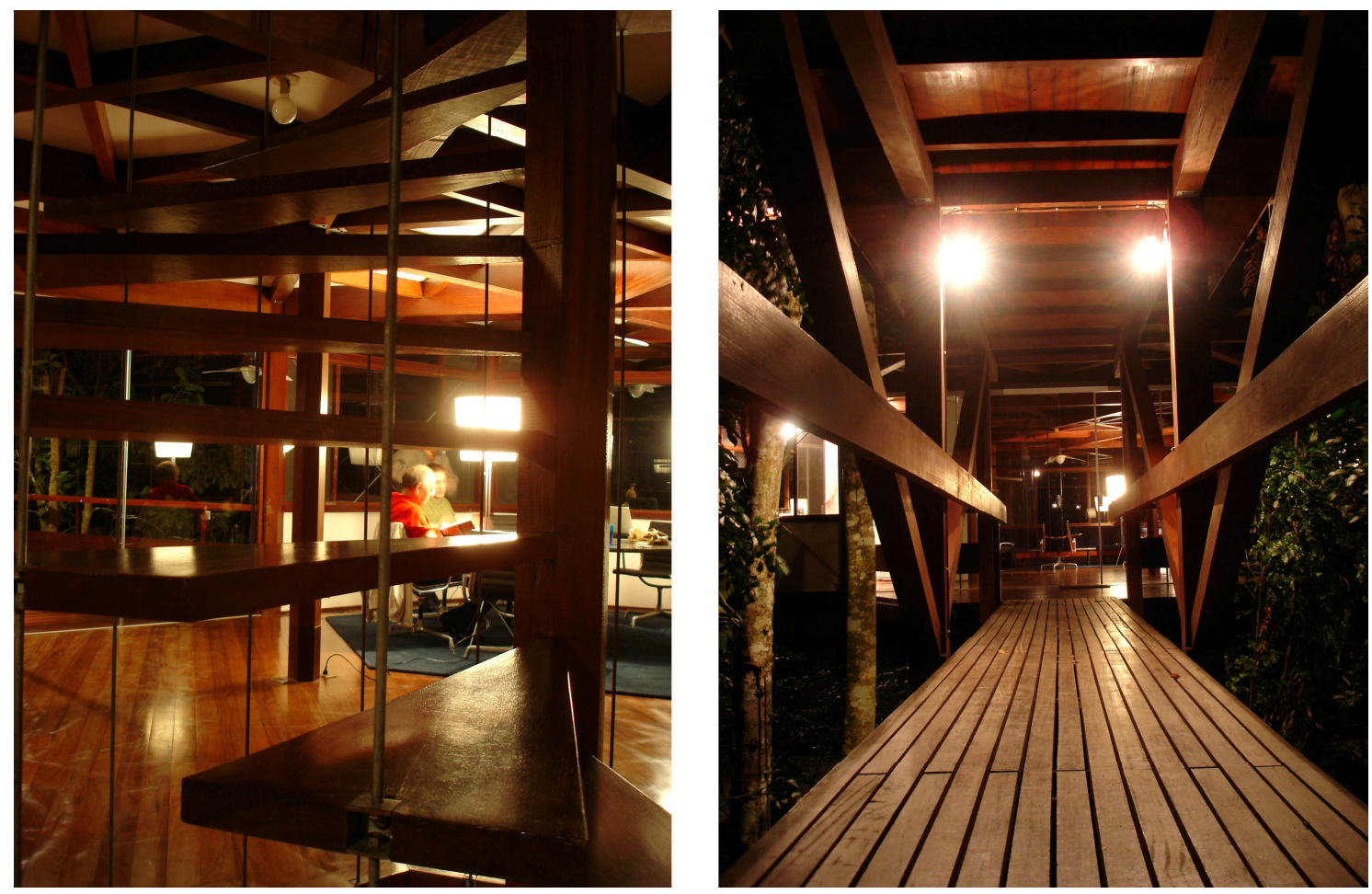

Fig. 7.17: Escada em madeira e cabos de aço e passarela coberta. (fonte: autora) 


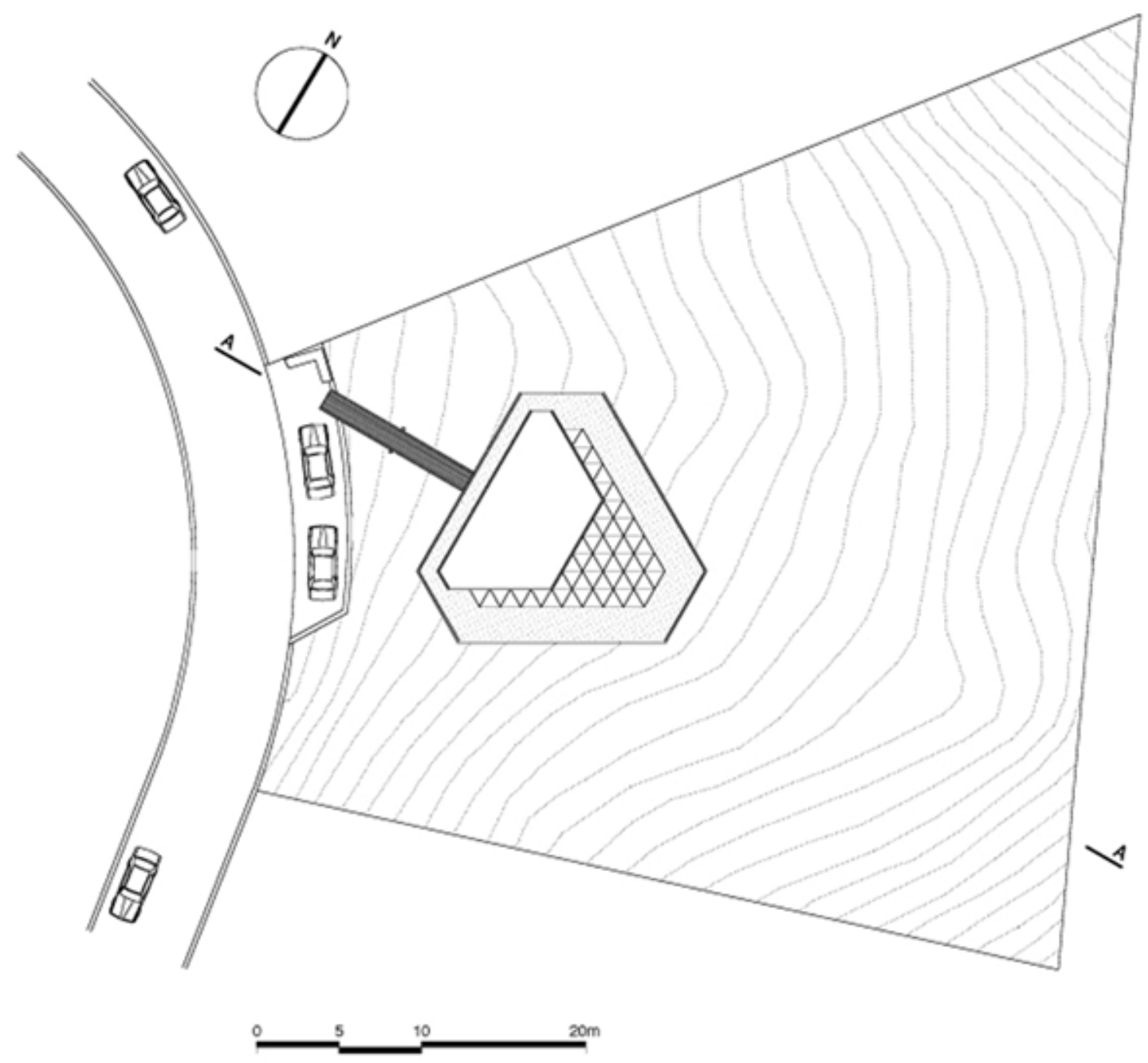

Fig. 7.18: Implantação. (fonte: arquivo pessoal Marcos Acayaba) 


\section{Capítulo 7}

Residência Baeta e Residência Marcos Acayaba

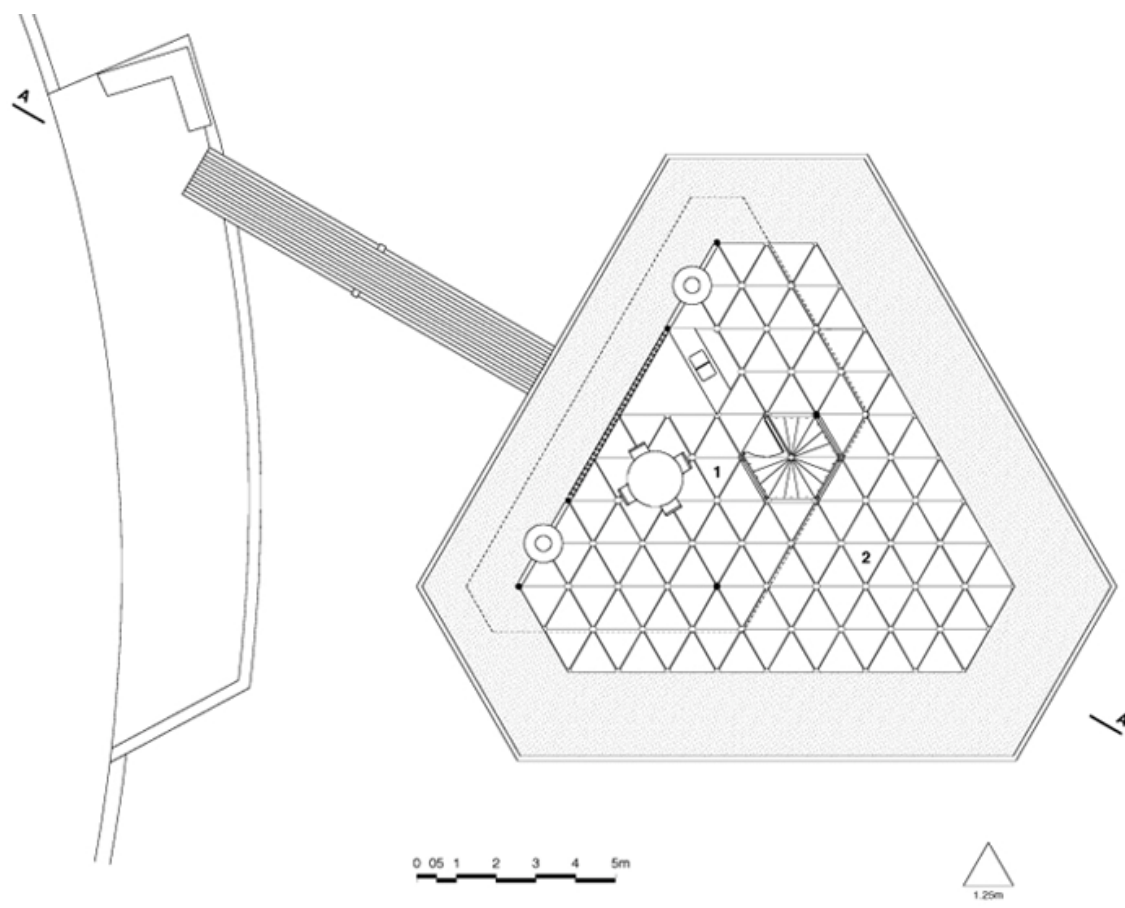

1. Terraço coberto

Terraço descoberto

Fig. 7.19: Planta cobertura. (fonte: arquivo pessoal Marcos Acayaba)

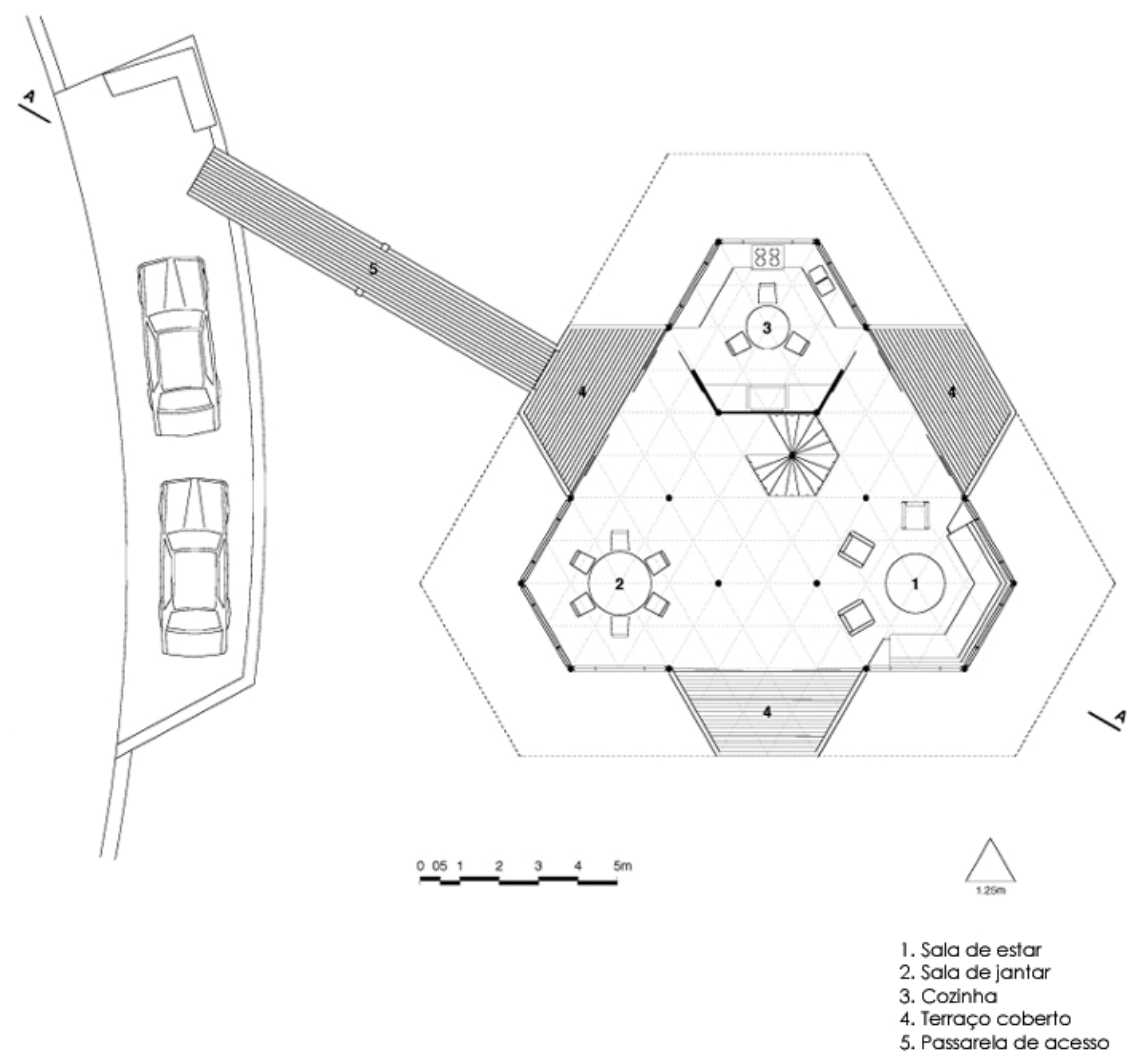

Fig. 7.20: Planta sala/cozinha. Pavimento de acesso à residência. (fonte: arquivo pessoal Marcos Acayaba) 
Capítulo 7

Residência Baeta e Residência Marcos Acayaba

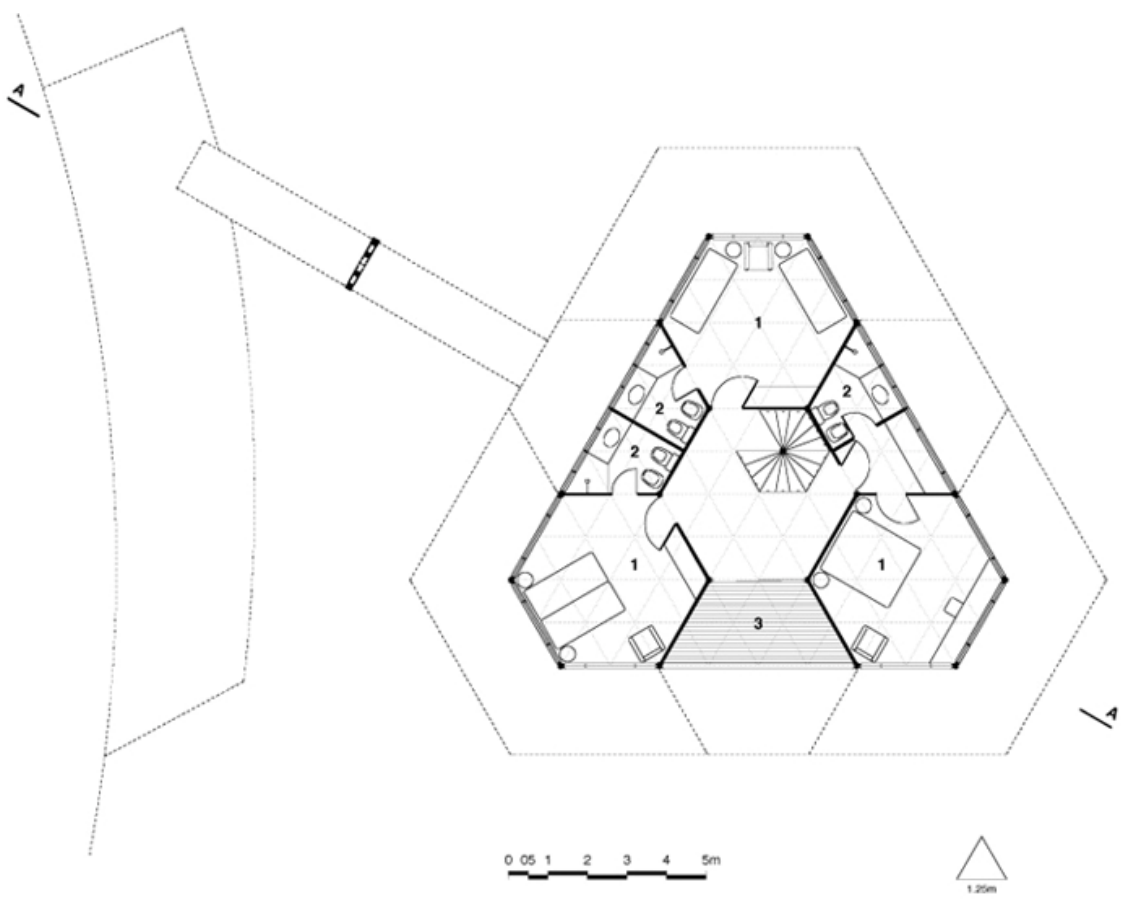

1. Dormitório

2. Sanitário

Fig. 7.21: Planta dormitórios. (fonte: arquivo pessoal Marcos Acayaba)

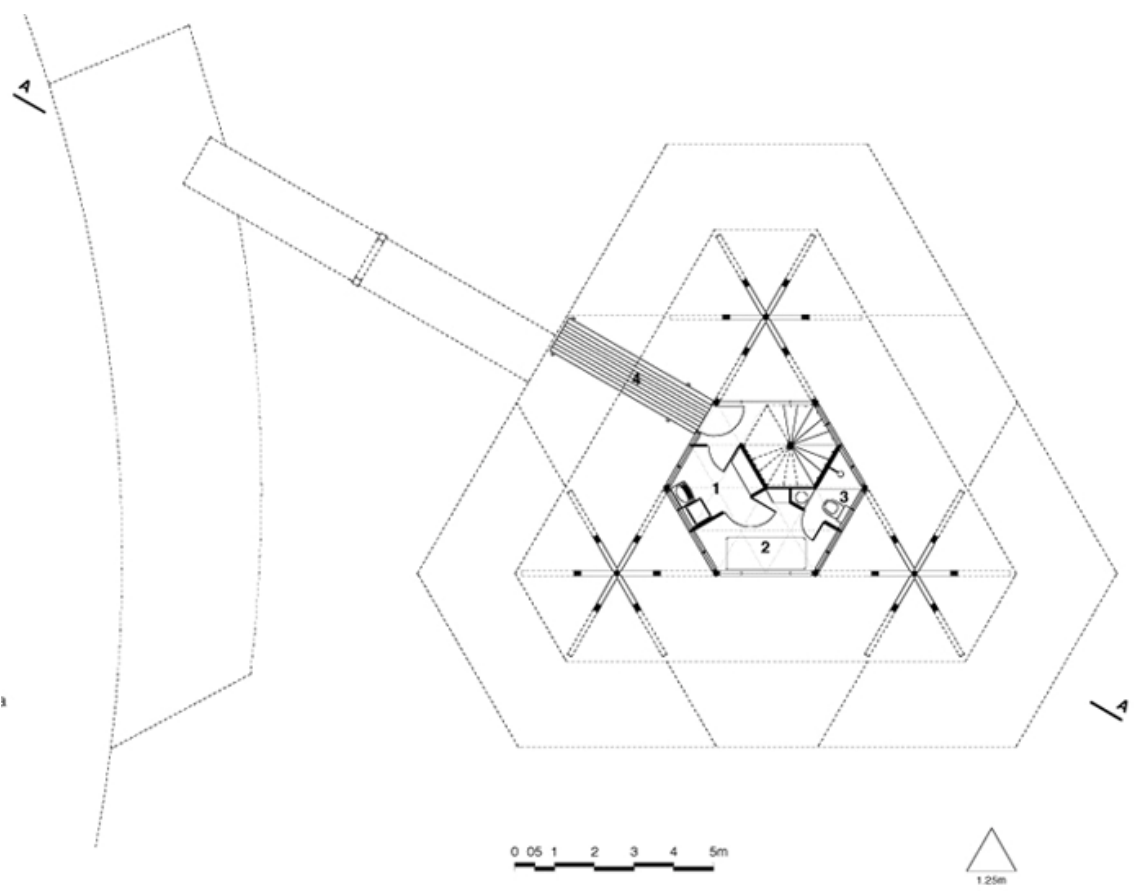

Fig. 7.22: Planta serviços. (fonte: arquivo pessoal Marcos Acayaba) 


\section{Capítulo 7}

Residência Baeta e Residência Marcos Acayaba

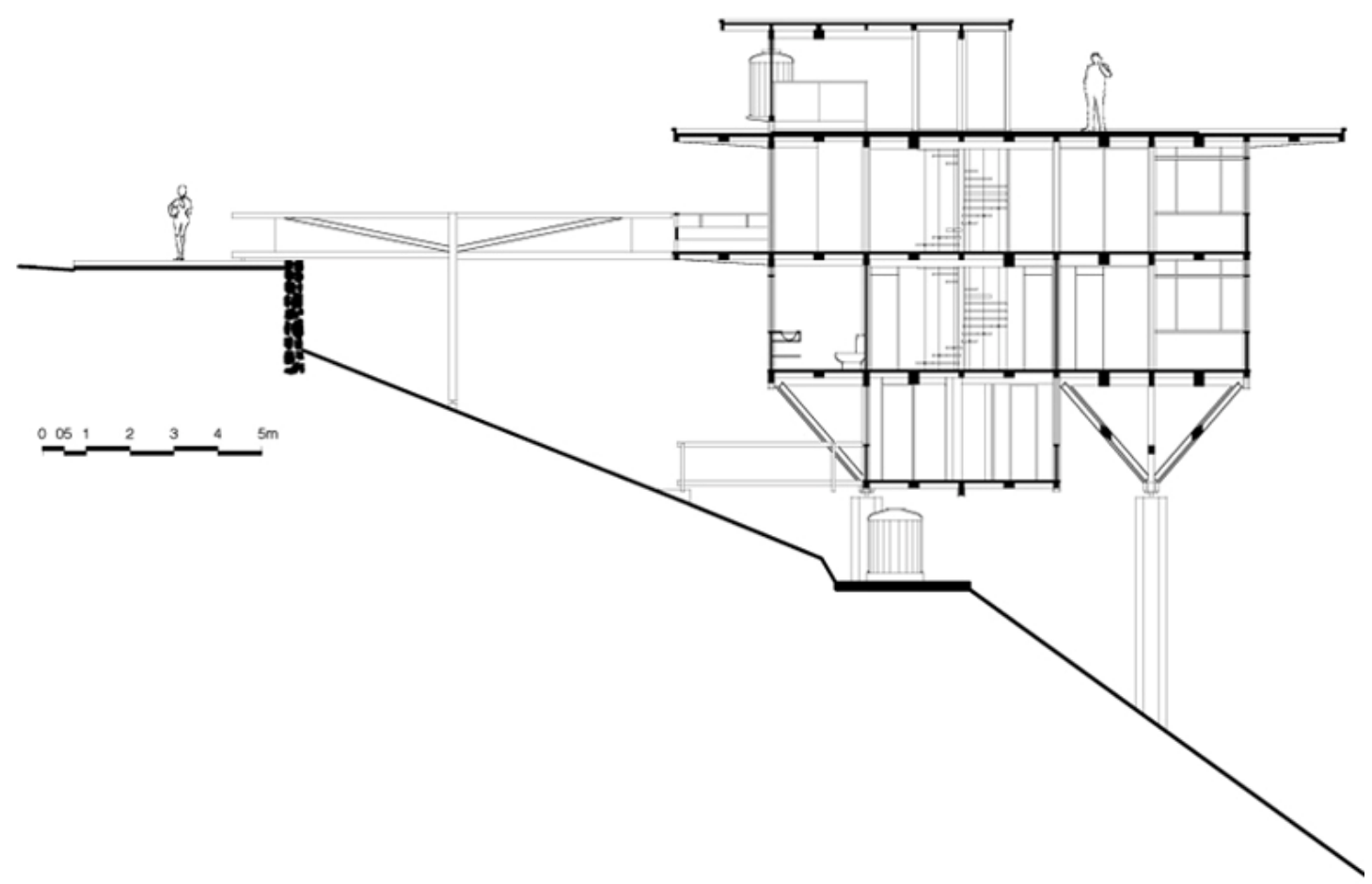

Fig. 7.24: Corte AA. (fonte: arquivo pessoal Marcos Acayaba) 
Essa casa adota o mesmo sistema construtivo da Residência Baeta, o sistema modular de base triangulada, mas é apoiada somente em três pontos, (A Baeta apóia-se em seis). Foi erguida em 40 dias por quatro homens.
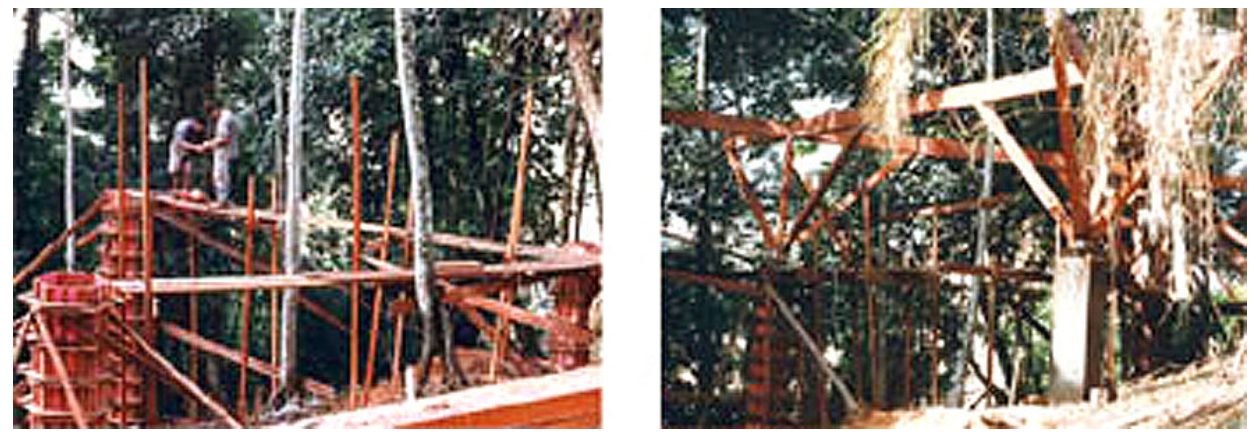

Fig. 7.25: Moldagem dos tubulões de concreto e início da montagem da estrutura. (fonte: arquivo pessoal Marcos Acayaba)
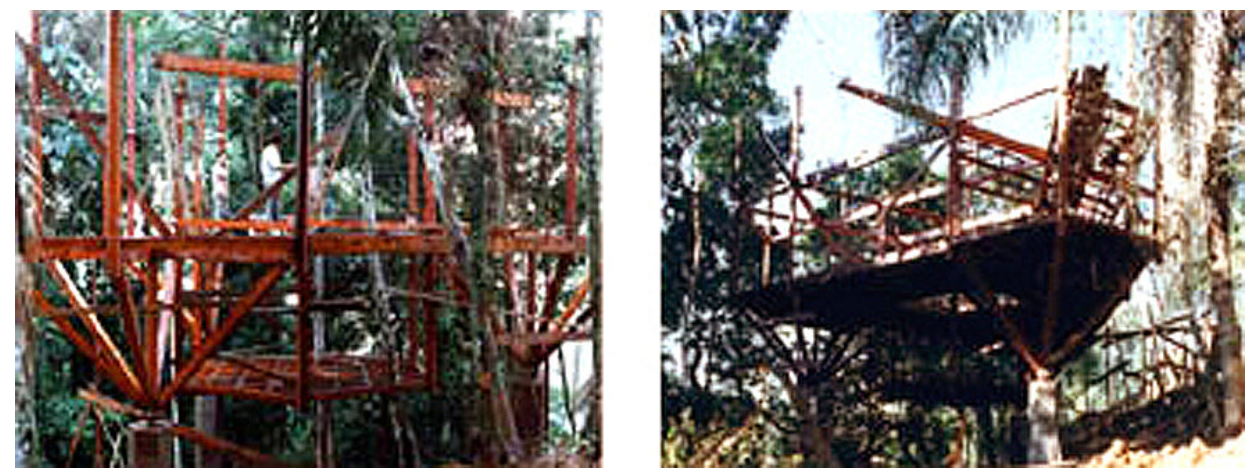

Fig. 7.26: Montagem da estrutura. (fonte: arquivo pessoal Marcos Acayaba)
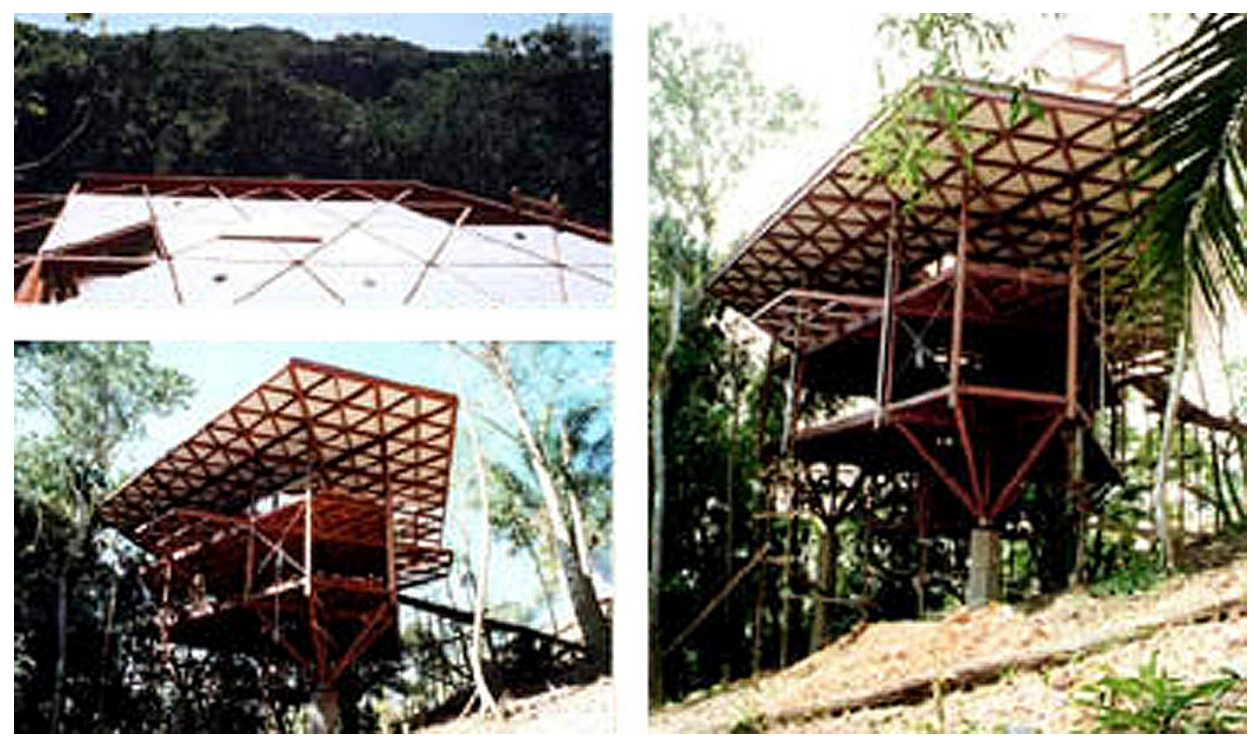

Fig. 7.27: Colocação das placas pré-moldadas na laje do terraço. (fonte: arquivo pessoal Marcos Acayaba) 


\section{Capítulo 7}

Residência Baeta e Residência Marcos Acayaba

As vedações são compostas por vidro e painéis industrializados de madeira, como nas residências Baeta e Hélio Olga, um material muito adequado a esse tipo de sistema construtivo, por ser leve e não sobrecarregar a estrutura.

As instalações hidráulicas são praticamente todas aparentes. Somente fiações elétricas correm entre piso e forro.
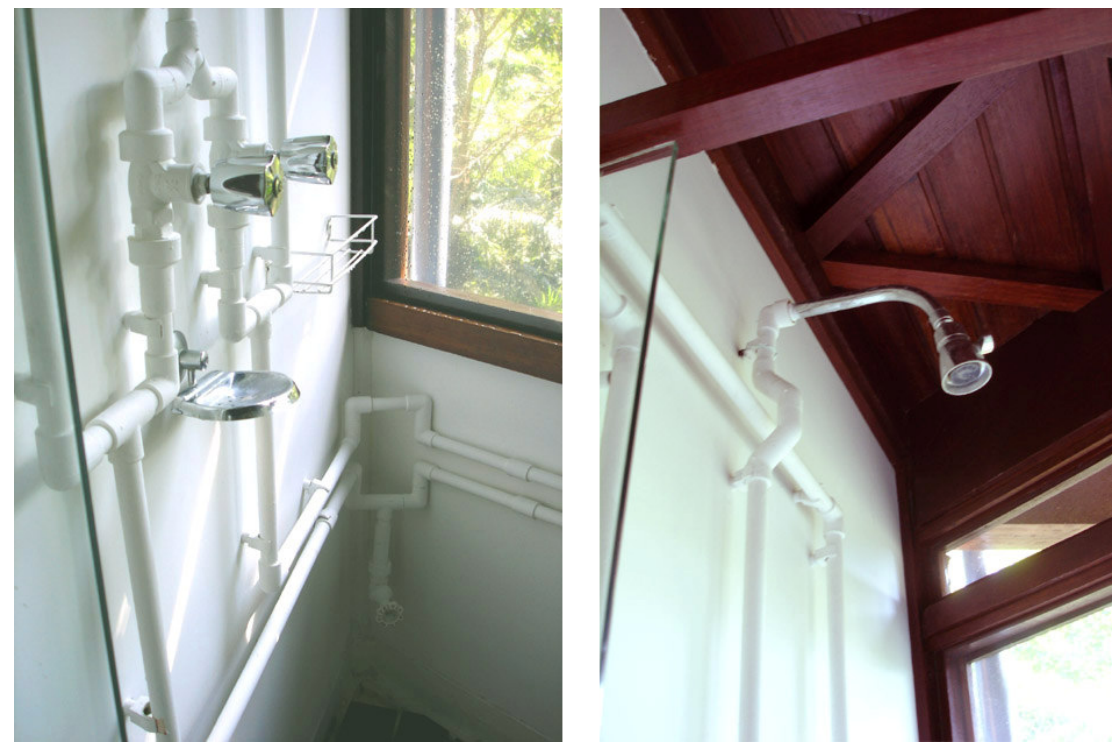

Fig. 7.28: Instalações hidráulicas aparentes nos sanitários. (fonte: autora)
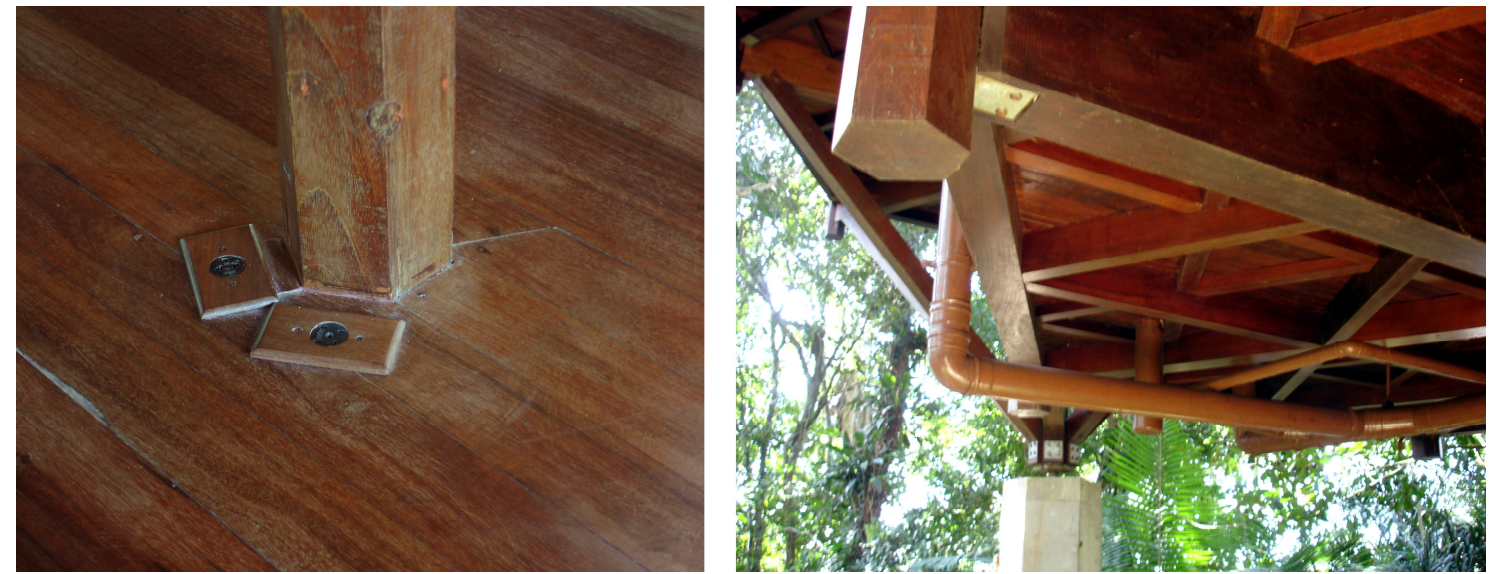

Fig. 7.29: Instalações elétricas entre piso e forro, tomadas de chão. Tubulações de esgoto abaixo do primeiro piso (serviços). (fonte: autora)

Assim como na Residência Baeta, a solução adotada para os caixilhos é muito simples. Lâminas de vidros temperados correm entre baguetes de madeira fixos ao peitoril. Telas de proteção contra insetos correm pelo lado externo. 


\section{Capítulo 7}

Residência Baeta e Residência Marcos Acayaba
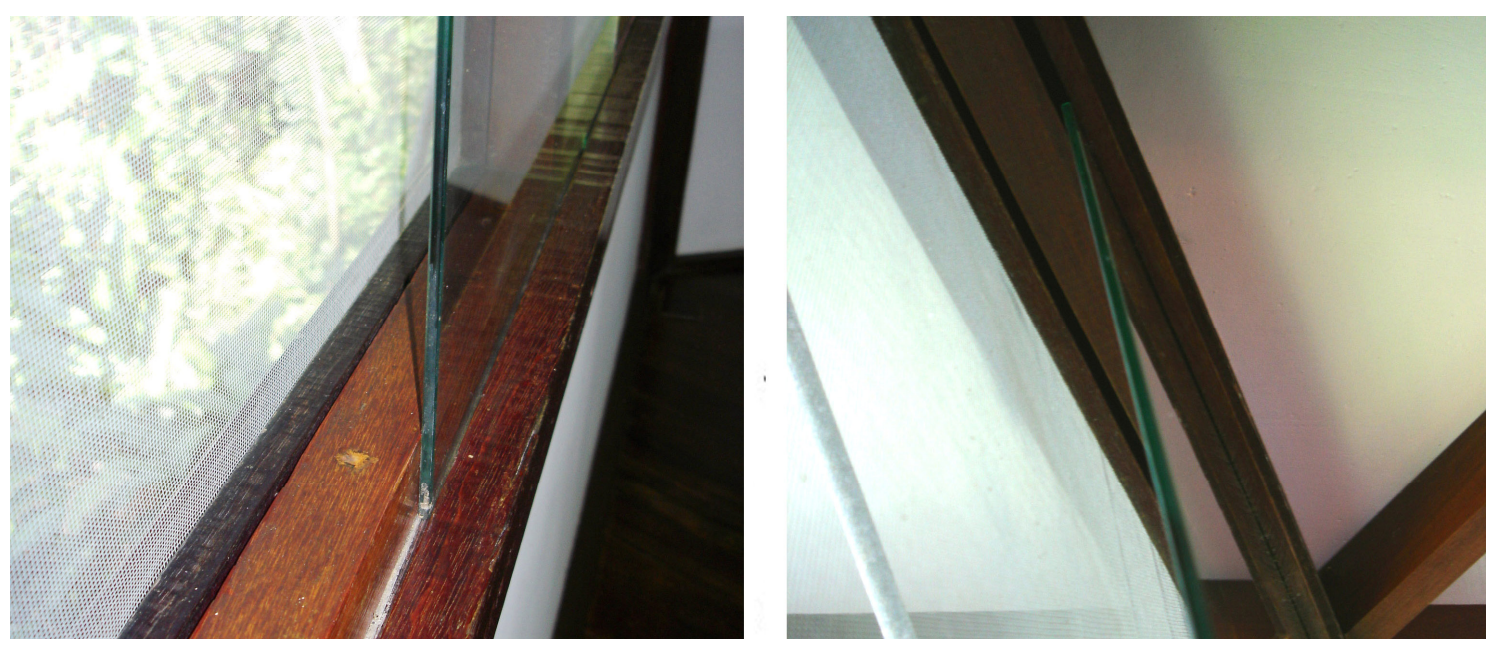

Fig. 7.30: Caixilho. Detalhe do peitoril e da guia superior. (fonte: autora)
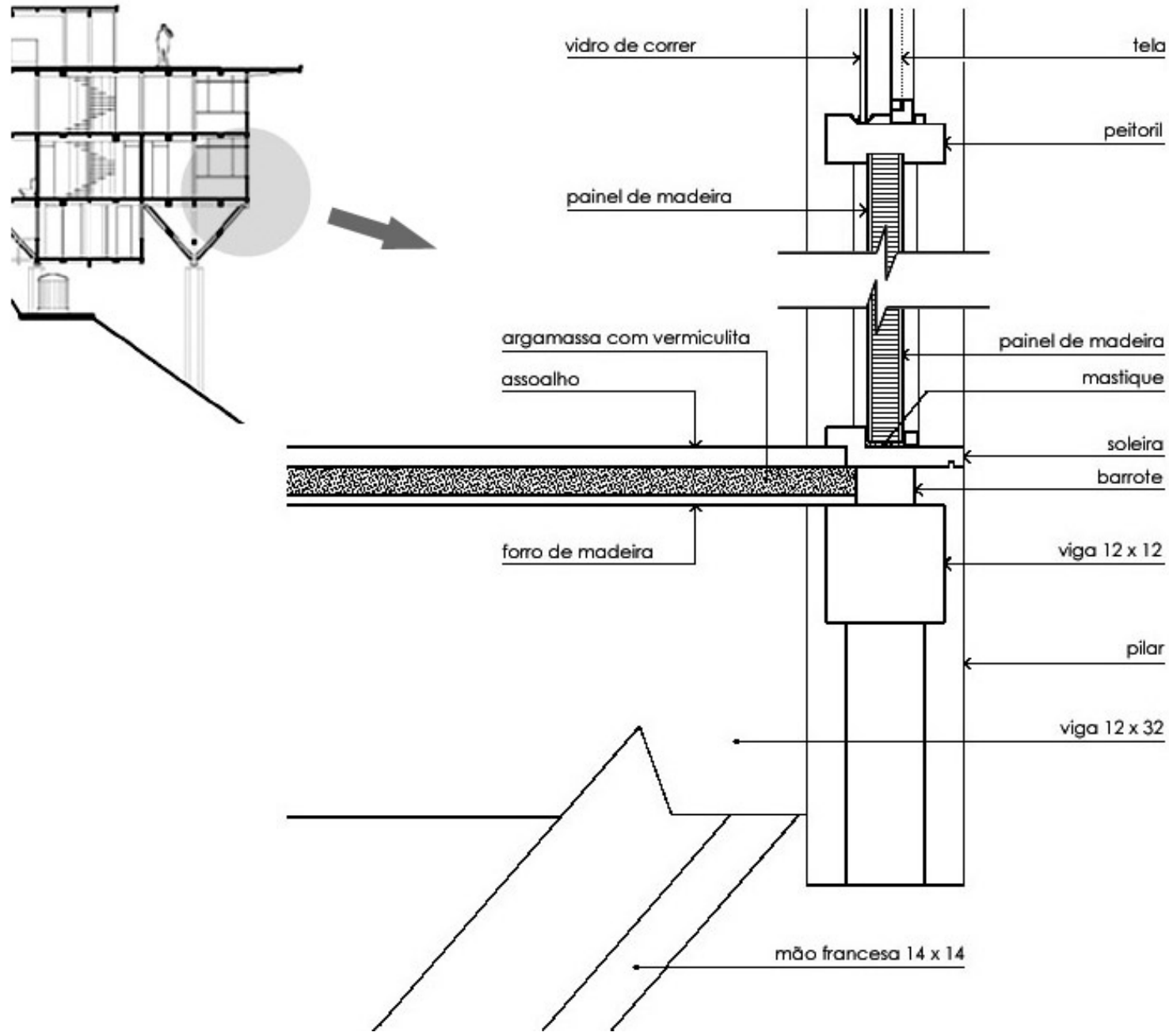

Fig. 7.31: Detalhe parede em corte - ampliação. (fonte: arquivo pessoal Marcos Acayaba editada pela autora) 


\section{Capítulo 7}

Residência Baeta e Residência Marcos Acayaba

Outra solução empregada associadamente a esse sistema estrutural que se destaca, é o tipo de laje utilizada como piso do terraço.

Entre pisos, utilizou-se a mesma dos outros projetos: argamassa e assoalho sobre barrotes com forro de madeira, mas na laje de piso do terraço, adotouse uma laje composta por camadas: placas de concreto adicionado de cinasita (argila expandida), argamassa adicionada de vermiculita, manta termoplástica de impermeabilização e seixos rolados ou argila expandida (seixos na laje de piso e argila expandida na de cobertura).

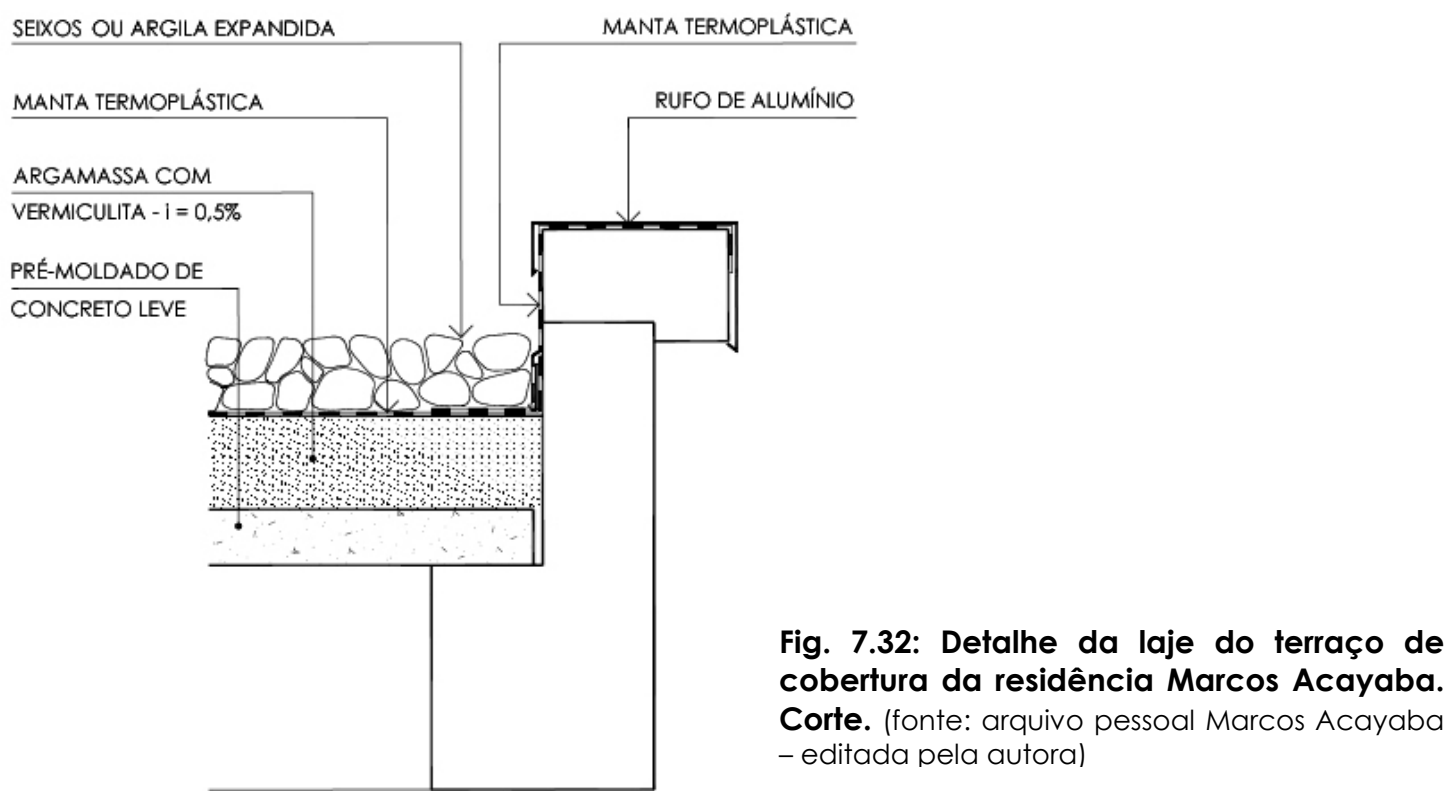

A cinasita, ou argila expandida, é um agregado leve que se apresenta em forma de bolinhas de cerâmica leves e arredondadas, com uma estrutura interna formada por uma espuma cerâmica com microporos e com uma casca rígida, resistente e impermeável (VERMICULITA, 2007). É utilizada como agregado do concreto, reduzindo seu peso e melhorando seu desempenho no conforto térmico e acústico.

A vermiculita é um mineral semelhante à mica, formado essencialmente por silicatos hidratados de alumínio e magnésio. Quando submetida a um aquecimento adequado, a água contida entre as suas milhares de lâminas se transforma em vapor fazendo com que as partículas explodam e se 


\section{Capítulo 7}

Residência Baeta e Residência Marcos Acayaba

transformem em flocos sanfonados. Cada floco expandido aprisiona consigo células de ar inerte, o que confere ao material excepcional capacidade de isolação (VERMICULITA, 2007). Agregada à argamassa, a vermiculita confere à laje baixo peso, boa resistência mecânica e melhor isolamento térmico e acústico.

Segundo Acayaba, a laje que adota as placas pré-moldadas de concreto foi mais eficiente, pois apresenta melhor isolamento acústico e continua sendo uma solução leve, que poderia ser utilizada em todos os pisos.

[as lajes de piso do terraço] Ficaram tão boas que depois me arrependi de não as ter usado na casa toda. Os outros pisos feitos sobre barrotes e forro de madeira, com argamassa isolante de vermiculita, mais assoalho, acabaram se tornando a maior fonte de críticas da casa, pelo ruído das pessoas andando. É uma questão de massa. Os pisos em madeira são muito leves, e estrutura fica flexível, ao contrário das lajes feitas com placas pré-moldadas (ACAYABA, 2004, v.1, p. 109).

Na laje de piso do terraço, são utilizados seixos rolados por sobre a manta de impermeabilização na região dos beirais. Esse recurso foi utilizado para dispensar o uso de guarda-corpo no terraço, demarcando uma área de recuo em relação à borda da laje.

Segundo Acayaba, a intenção era mais paisagística, já que em termos de isolamento térmico e peso, a argila expandida é mais vantajosa. A utilização dos seixos não acarreta problemas de conforto, por estarem sobre a área do beiral (informação verbal)².
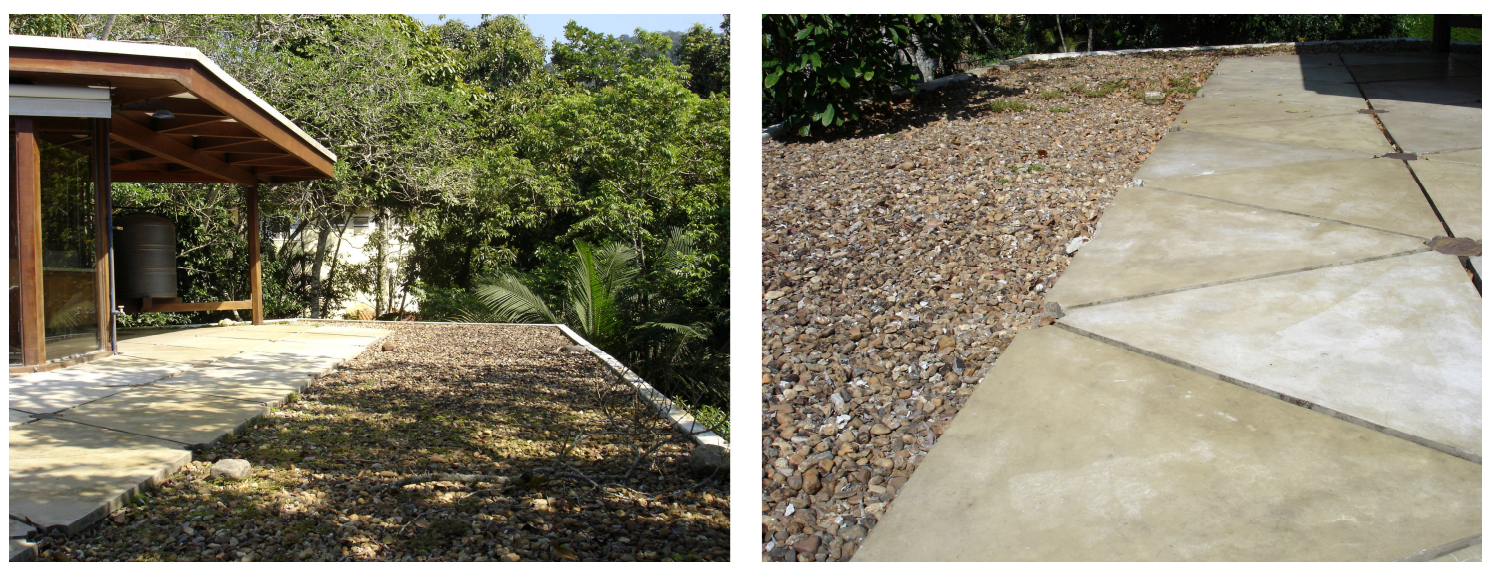

Fig. 7.33: Terraço. Seixos criam área de segurança sobre o beiral. (fonte: autora)

2 Informação dada por Acayaba em visita a sua casa no Guarujá. 


\section{Capítulo 7}

Residência Baeta e Residência Marcos Acayaba

Na laje da área coberta do terraço, onde há necessidade de isolamento térmico, foi empregada a argila expandida no lugar dos seixos.

Nesse caso, o tamanho das esferas de argila é maior do que quando utilizada como agregado, girando em torno dos $1,5 \mathrm{~cm}$ de diâmetro.

Devido à pequena espessura e massa das lajes, o recurso da argila expandida se torna muito interessante, na medida em que, além de não ser um material caro, apresenta bom isolamento térmico e baixo peso específico, propiciando melhores condições de conforto e evitando a sobrecarga na estrutura e nas fundações.

O recurso da argila expandida sobre a laje de terraço também foi utilizado nas casas da Vila Butantã, como mostra o capítulo 9. 


\subsection{A solução construtiva:}

\section{Estrutura em madeira pré-fabricada com base modular triangulada}

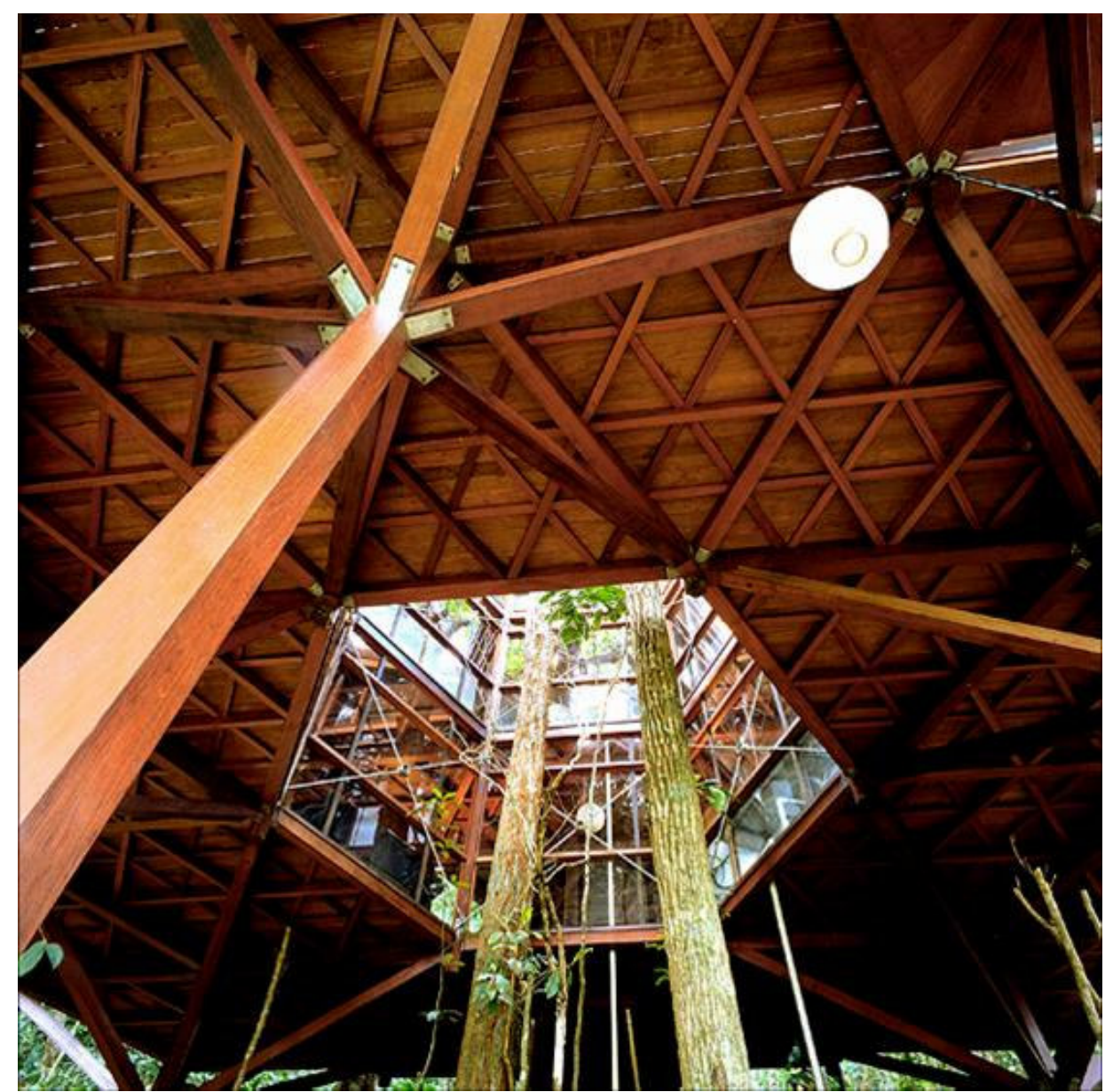

Fig. 7.34: Vista da parte inferior da casa Baeta a partir do caminho de acesso. (fonte: arquivo pessoal Marcos Acayaba)

Os dois projetos apresentados nos itens anteriores ilustram bem o estudo desenvolvido na aplicação do sistema adotado em uma série de casas de condições semelhantes de implantação (terreno de forte inclinação).

Como já dito, esse princípio construtivo consiste na criação de uma malha triangular horizontal, auto-travada no sentido horizontal, e a partir da qual se articula toda a estrutura, permitindo uma ocupação espacial mais dinâmica, elevando a casa e liberando o solo. 


\section{Capítulo 7}

Residência Baeta e Residência Marcos Acayaba

Com três direções há mais opções, são mais fáceis os acertos com as árvores existentes e a topografia, do que com as duas direções da trama ortogonal. Além disso, com o desenho resultante em planta, praticamente todos os ambientes da casa oferecem vista para o mar, o que, numa solução ortogonal, ficaria restrito ao lado fronteiro. Com uma geometria triangular, em princípio indeformável, a estrutura é naturalmente autotravada, nos planos horizontais. Não foi necessário atirantamento abaixo dos pisos [contraventamentos horizontais], como na residência Hélio Olga (ACAYABA, 2004, p. 233).
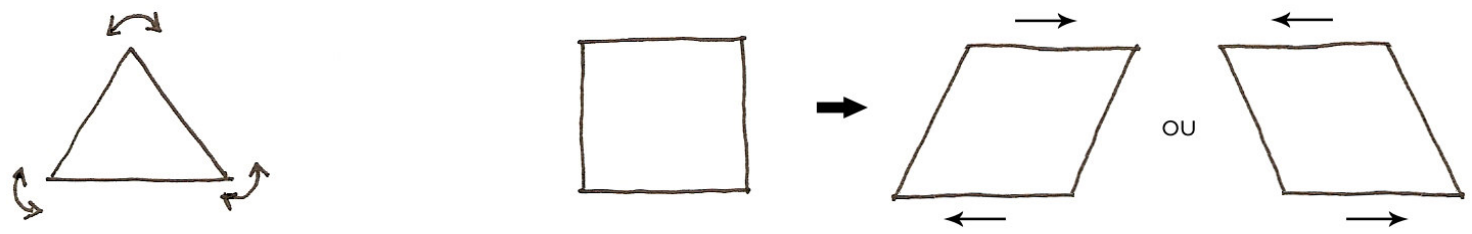

Fig. 7.35: Croqui. O triângulo é uma forma geometricamente indeformável. Já o quadrado é deformável quando não utilizados travamentos nas diagonais internas. (fonte: autora)

Todas as cargas do edifício concentram-se em poucos pontos de apoio através do uso de mãos francesas, conferindo à estrutura um aspecto semelhante ao de uma árvore.

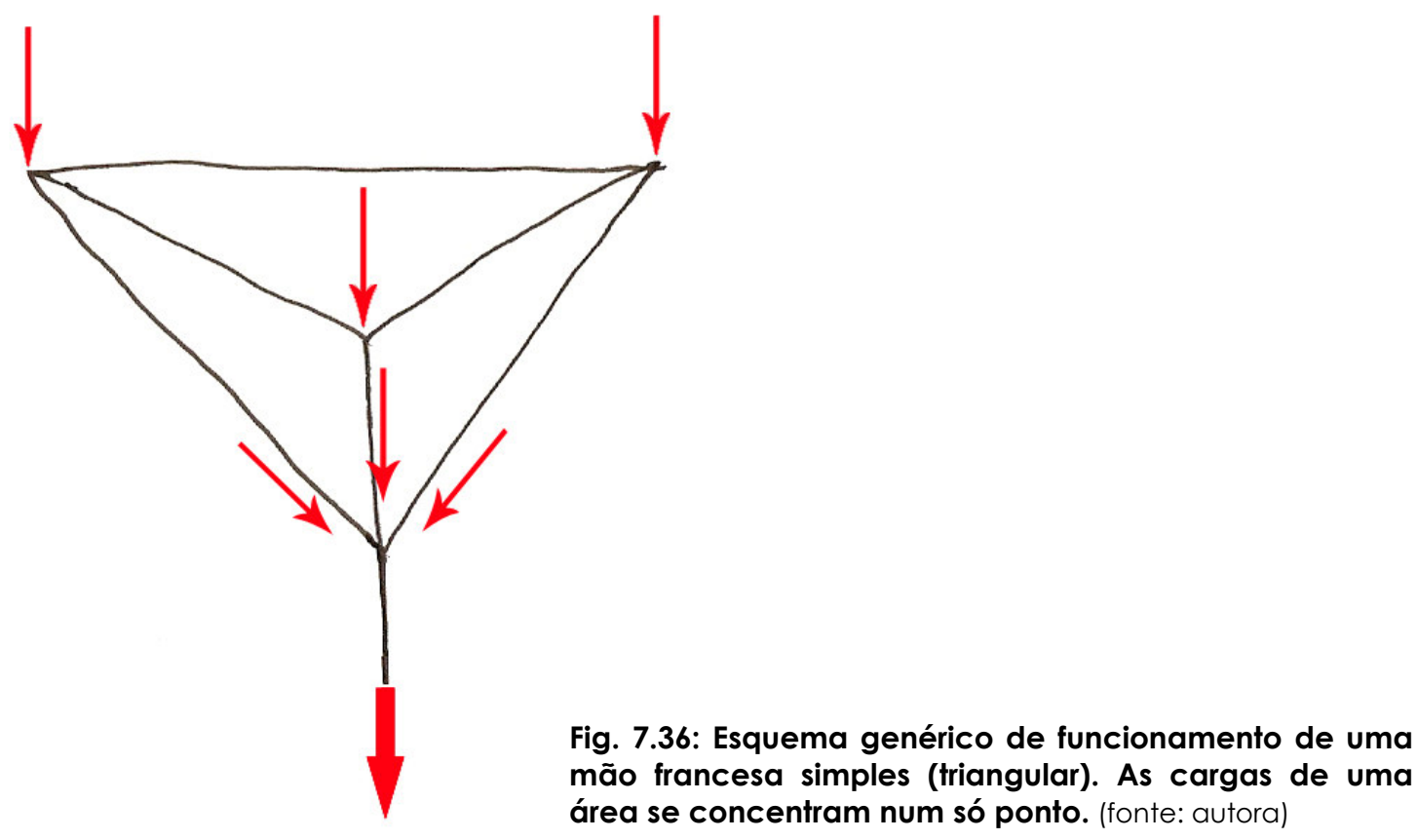




\section{Capítulo 7}

Residência Baeta e Residência Marcos Acayaba

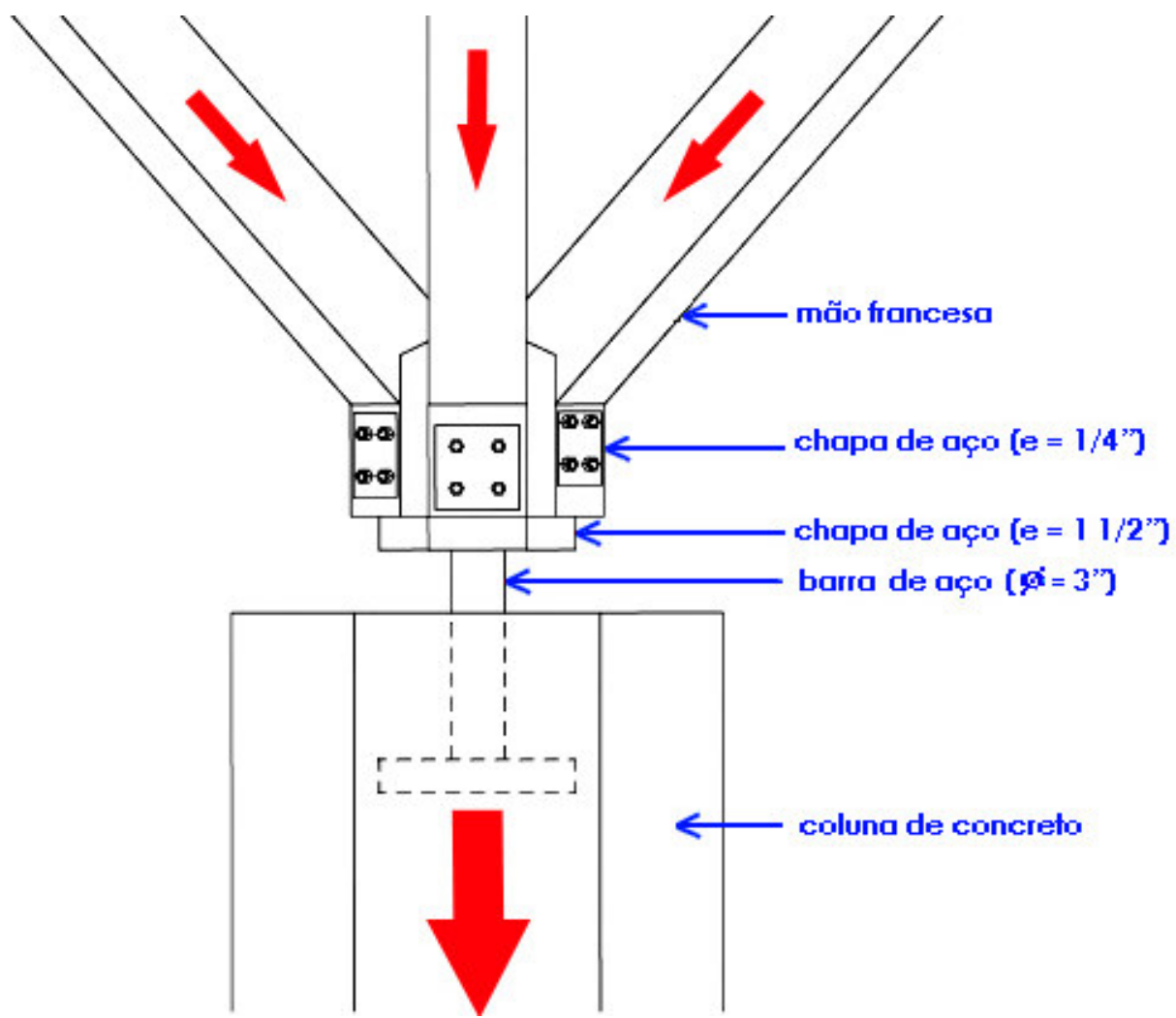

Fig. 7.37: Esquema de forças. Encontro entre mão-francesa e coluna de concreto da casa Marcos Acayaba. Peça de aço concentra as forças fazendo a transição da estrutura em madeira para a coluna de fundação. (fonte: arquivo pessoal Marcos Acayaba - editada pela autora)

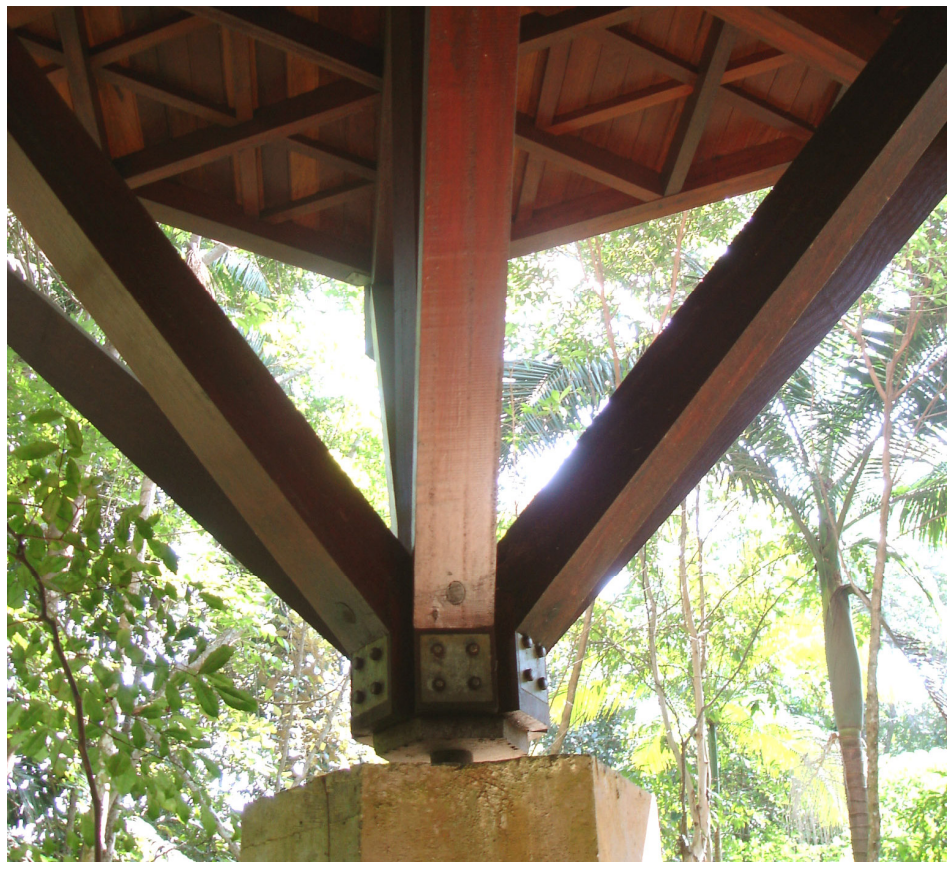

Fig. 7.38: Três mãos-francesas, com seis braços cada, sustentam a casa Marcos Acayaba. (fonte: autora) 


\section{Capítulo 7}

Residência Baeta e Residência Marcos Acayaba

Convém ressaltar que a escolha da madeira a ser utilizada na estrutura depende não somente de suas características específicas. Segundo Hélio Olga (SOUZA JR., 2007a), dentre uma gama de opções com características similares, é escolhida a madeira que estiver disponível no momento da construção, o importante é que a densidade seja de $1000 \mathrm{~kg} / \mathrm{m}^{3}$.

A madeira utilizada nas estruturas das duas residências foi o Jatobá. Segundo Nogueira e Nogueira (2001), é uma madeira muito resistente a fungos e cupins, que possui alto peso específico, baixa retratibilidade e alta resistência mecânica.

O projeto da residência Baeta foi o primeiro a utilizar esse sistema construtivo e foi todo detalhado a mão. Desde os primeiros esboços ao projeto executivo.

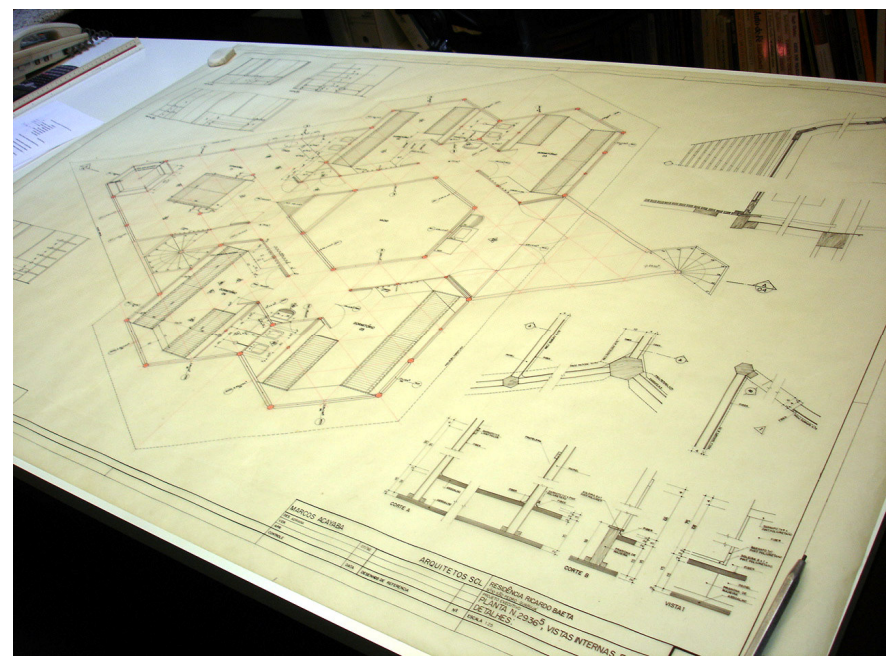

Fig. 7.39: Prancha desenhada a mão. Projeto executivo residência Baeta. (fonte: autora)

Já a residência Marcos Acayaba e os outros projetos que utilizam esse sistema passaram por estudos realizados por meio de maquetes eletrônicas, e seus projetos executivos foram feitos em ArchiCAD.

A partir da experiência adquirida no primeiro projeto que utilizava o sistema de triangulação (residência Baeta), Acayaba elaborou um protótipo, com a finalidade de verificar a viabilidade de uma aplicação mais generalizada. Ele se aplica a uma casa de cerca de $170 \mathrm{~m}^{2}$ a ser implantada em terreno de topografia acidentada. 


\section{Capítulo 7}

Residência Baeta e Residência Marcos Acayaba

O protótipo foi desenvolvido eletronicamente. E a estrutura reproduzida também em modelo físico em escala de 1:15. Os nós estruturais e um módulo da grelha de piso foram reproduzidos em escala de 1:1.

O resultado de todo o estudo foi apresentado na $2^{a}$ Bienal Internacional de Arquitetura em São Paulo, em 1993, e serviu de base para a construção da residência Marcos Acayaba, em 1996. A partir de então o sistema vem se consolidando e, em 2006, foi utilizado na construção de mais uma casa, também no Guarujá.

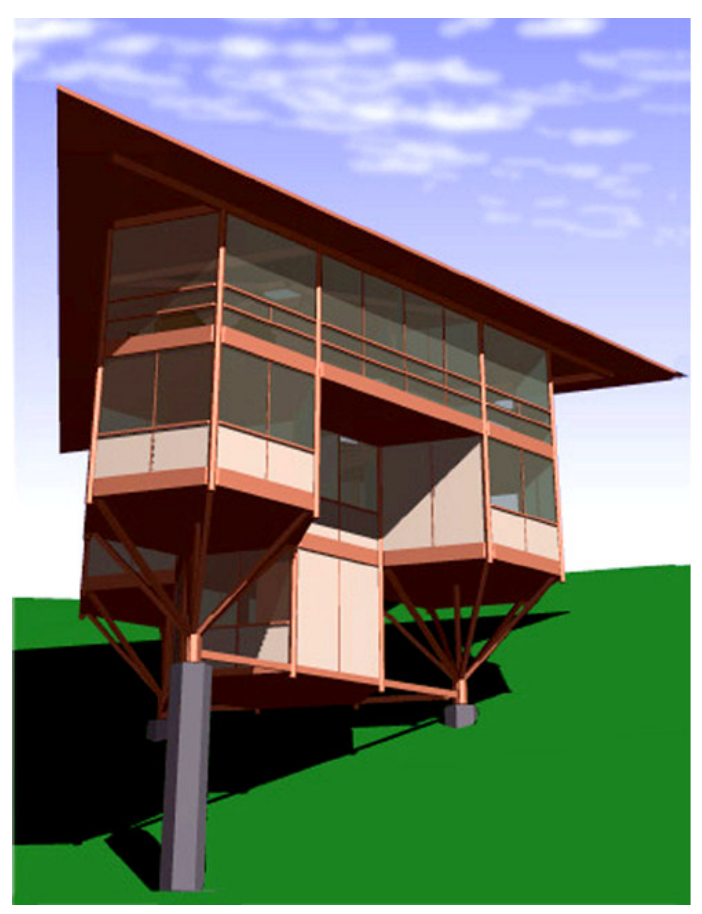

Fig. 7.40: Protótipo. Maquete eletrônica. (fonte: arquivo pessoal Marcos Acayaba)

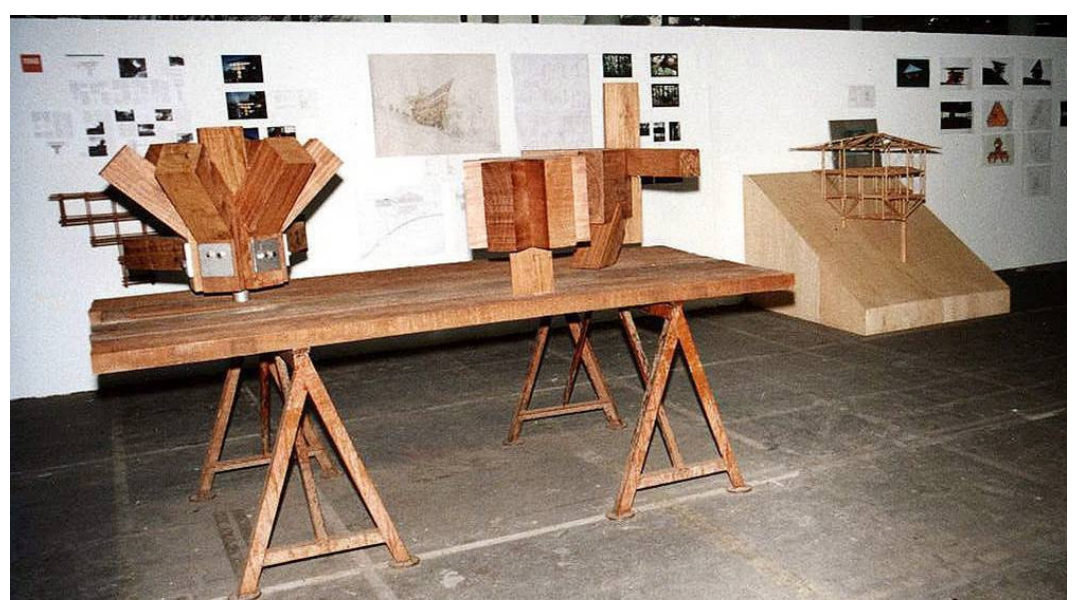

Fig. 7.41: Exposição dos modelos em escala 1:1 e 1:15 na Bienal de Arquitetura, em 1993. (fonte: arquivo pessoal Marcos Acayaba) 


\subsection{Considerações sobre os projetos}

Com a experiência adquirida com a residência Hélio Olga, Acayaba consegue explorar, nesses projetos, ainda mais as potencialidades da madeira.

Levando-se em conta a complexidade e as dificuldades de montagem demandada pelos elementos de contratraventamento da casa de Hélio, e percebendo que seria possível fazer encaixes em madeira com ângulos que não necessariamente fossem retos, o arquiteto desenvolveu esse sistema triangularmente modulado (informação verbal) ${ }^{3}$.

A modulação em triângulos não é inédita. Arquitetos como Frank Lloyd Wright já trabalharam com esse desenho de módulo. No entanto, o que valoriza essas obras é a constituição de uma solução construtiva que consegue, ao mesmo tempo, resolver todas as necessidades espaciais relacionadas ao programa, associadamente às determinadas pelas características do local de implantação, pelos fluxos de materiais e mão de obra em canteiro, e pela resolução estrutural em si, resultando numa linguagem plástica muito expressiva que dialoga muito bem com a paisagem em que se insere.

Esses são projetos inéditos, tanto do ponto de vista construtivo quanto do ponto de vista espacial. Diferentemente dos projetos realizados mais no início de carreira de Acayaba, como os da residência Milan e da Fazenda Pindorama, o partido formal nesses casos não veio antes ou depois do partido construtivo. Partido formal e partido construtivo não se dividem. Há nesses projetos um único partido. Um, e um só, partido arquitetônico.

A arquitetura acontece aqui como uma simbiose única: arte, espaço, construção e abrigo.

\footnotetext{
3 Informação cedida por Acayaba em visita à residência Baeta, no Guarujá.
} 


\section{Capítulo 7}

Residência Baeta e Residência Marcos Acayaba

\subsection{Ficha técnica - Residência Baeta}

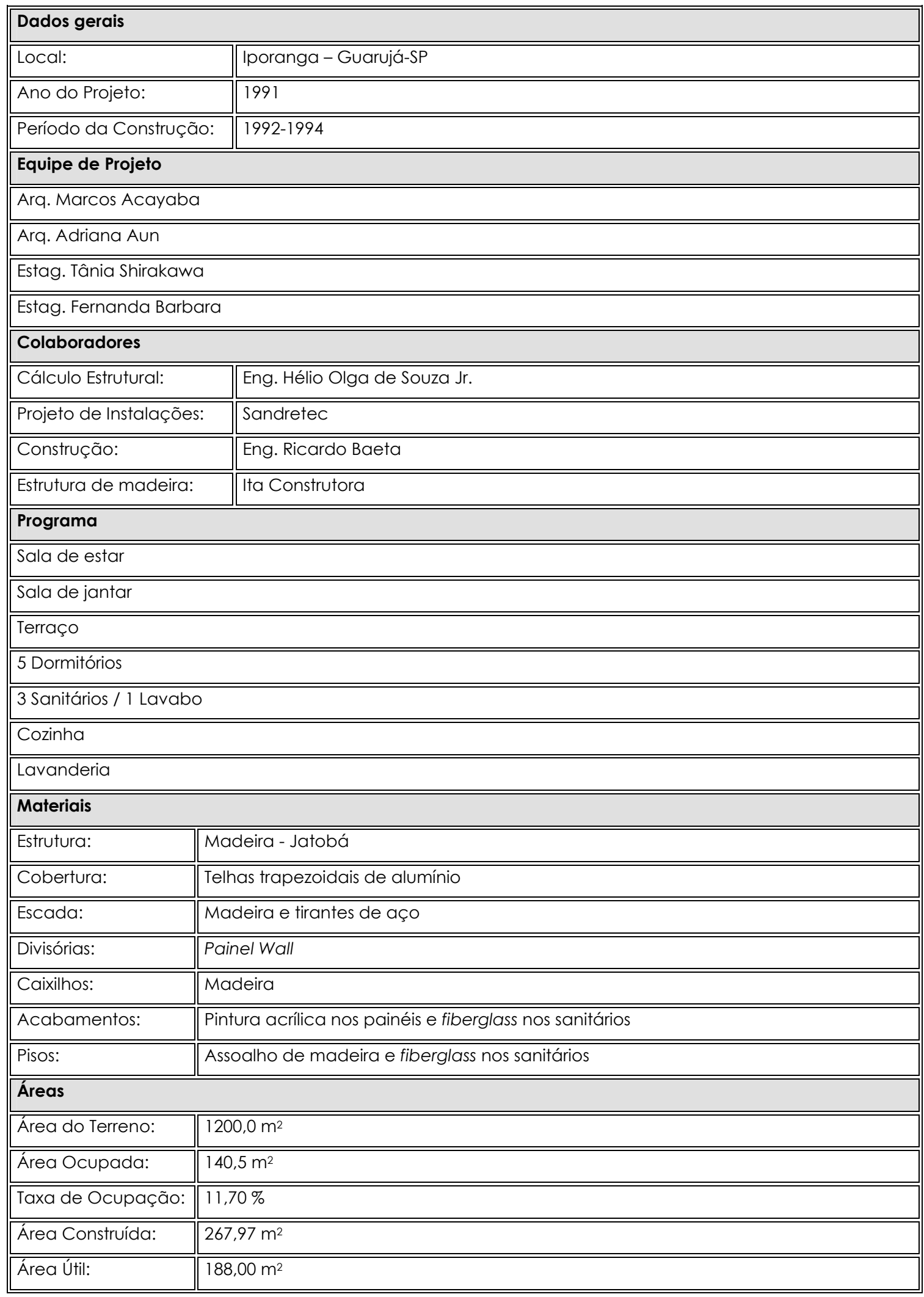




\section{Capítulo 7}

Residência Baeta e Residência Marcos Acayaba

\subsection{Ficha técnica - Residência Marcos Acayaba}

\begin{tabular}{|c|c|c|c|}
\hline \multicolumn{4}{|l|}{ Dados gerais } \\
\hline \multicolumn{2}{|l|}{ Local: } & & Tijucopava - Guarujá-SP \\
\hline \multicolumn{2}{|l|}{ Ano do Projeto: } & & 1996 \\
\hline \multicolumn{2}{|c|}{ Período da Construção: } & & $1996-1997$ \\
\hline \multicolumn{4}{|l|}{ Equipe de Projeto } \\
\hline \multicolumn{4}{|l|}{ Arq. Marcos Acayaba } \\
\hline \multicolumn{4}{|l|}{ Arq. Sueli Mizobe } \\
\hline \multicolumn{4}{|l|}{ Arq. Fábio Valentim } \\
\hline \multicolumn{4}{|l|}{ Arq. Mauro Halluli } \\
\hline \multicolumn{4}{|l|}{ Colaboradores } \\
\hline \multicolumn{2}{|l|}{ Cálculo Estrutural: } & & Eng. Hélio Olga de Souza Jr. \\
\hline \multicolumn{2}{|l|}{ Projeto de Fundações: } & & Eng. Luis F. Meirelles Carvalho \\
\hline \multicolumn{2}{|l|}{ Projeto de Instalações: } & & Sandretec \\
\hline \multicolumn{2}{|l|}{ Construção: } & & Ita Construtora \\
\hline \multicolumn{4}{|l|}{ Programa } \\
\hline \multicolumn{4}{|l|}{ Sala de estar } \\
\hline \multicolumn{4}{|l|}{ Sala de jantar } \\
\hline \multicolumn{4}{|l|}{3 Dormitórios } \\
\hline \multicolumn{4}{|l|}{3 Sanitários } \\
\hline \multicolumn{4}{|l|}{ Cozinha } \\
\hline \multicolumn{4}{|l|}{ Lavanderia } \\
\hline \multicolumn{4}{|c|}{ Dormitório e Sanitário de empregada } \\
\hline \\
\hline \multicolumn{4}{|r|}{ Madeira - Jatobá } \\
\hline \multicolumn{4}{|c|}{\begin{tabular}{l||l} 
Cobertura: & Laje impermeabilizada e pré-moldado de concreto leve
\end{tabular}} \\
\hline \multicolumn{2}{|l|}{ Escada: } & & Madeira e tirantes de aço \\
\hline \multicolumn{2}{|l|}{ Divisórias: } & & Painel Wall \\
\hline \multicolumn{2}{|l|}{ Caixilhos: } & & Madeira \\
\hline \multicolumn{2}{|l|}{ Acabamentos: } & & Pintura acrílica nos painéis e fiberglass nos sanitários \\
\hline & & Pisos: & Assoalho de madeira e fiberglass nos sanitários \\
\hline & & Áreas & \\
\hline & & Área do Terreno: & $1963,0 \mathrm{~m}^{2}$ \\
\hline & & Área Ocupada: & $133,0 \mathrm{~m}^{2}$ \\
\hline & & Taxa de Ocupação: & $6,0 \%$ \\
\hline & & Área Construída: & $251,0 \mathrm{~m}^{2}$ \\
\hline & & Área Útil: & $194,0 \mathrm{~m}^{2}$ \\
\hline
\end{tabular}


CAPÍTULO 8:

ESCOLA DE ENSINO FUNDAMENTAL JARDIM BELA VISTA II

(Mogi das Cruzes - SP, 2003-2005)

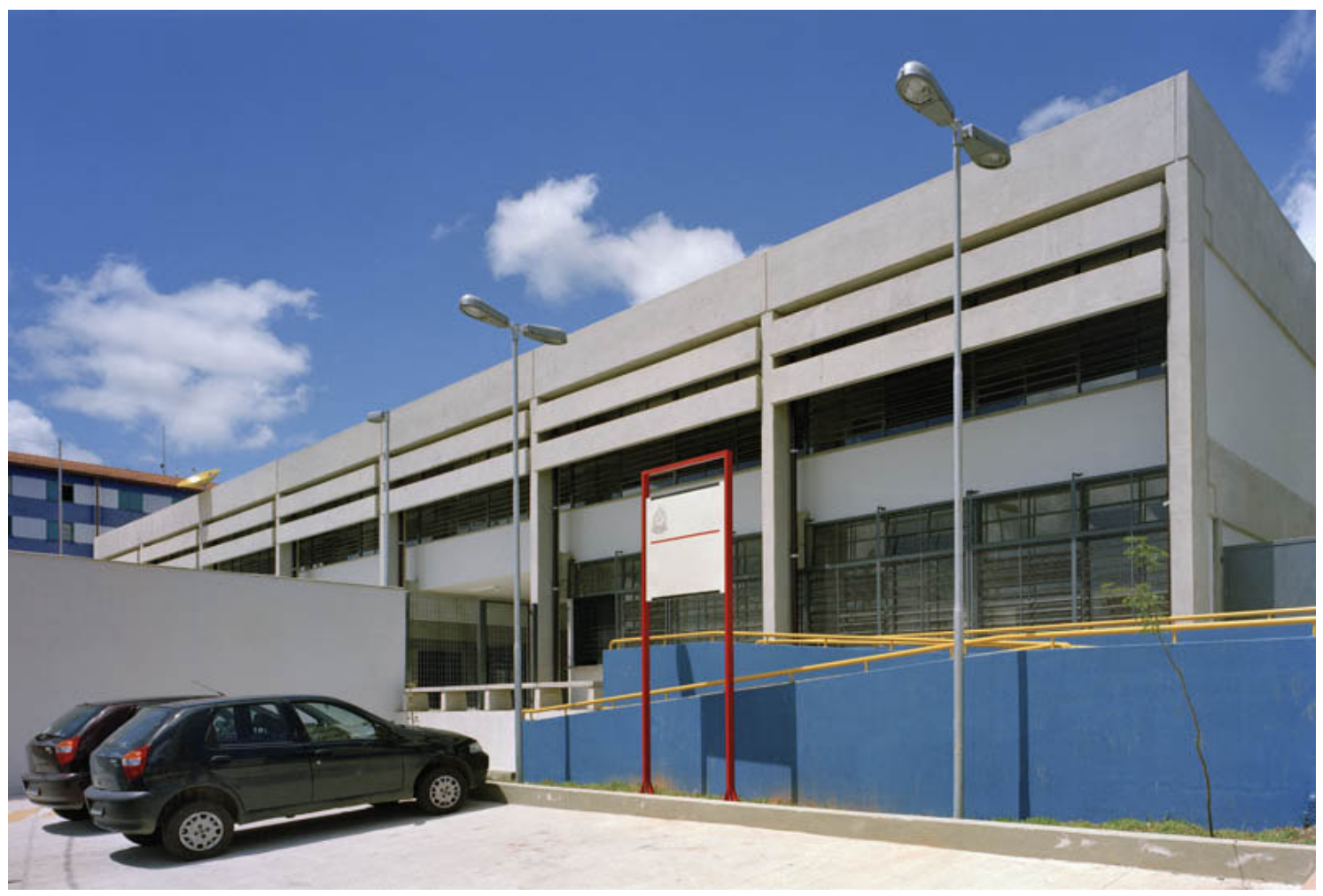

Fig. 8.1: Escola de Ensino Fundamental Jardim Bela Vista II. Entrada. (fonte: arquivo pessoal Marcos Acayaba) 


\section{Capítulo 8}

Escola de Ensino Fundamental Jardim Bela Vista II

\subsection{O projeto}

Junto ao espaço de lazer de um conjunto habitacional do CDHU (Companhia de Desenvolvimento Habitacional e Urbano), a Escola de Ensino Fundamental Jardim Bela Vista II ocupa uma área de cerca de $3000 \mathrm{~m}^{2}$ e foi desenvolvida seguindo padrões estabelecidos pelo FDE (Fundação para o Desenvolvimento da Educação).

Num terreno praticamente plano, o edifício tem uma implantação horizontal, dividindo o programa em três blocos de dois pavimentos, estruturalmente independentes, ligados pelos volumes das escadas e conformando uma implantação em 'U', com um pátio central coberto e dois pátios descobertos.
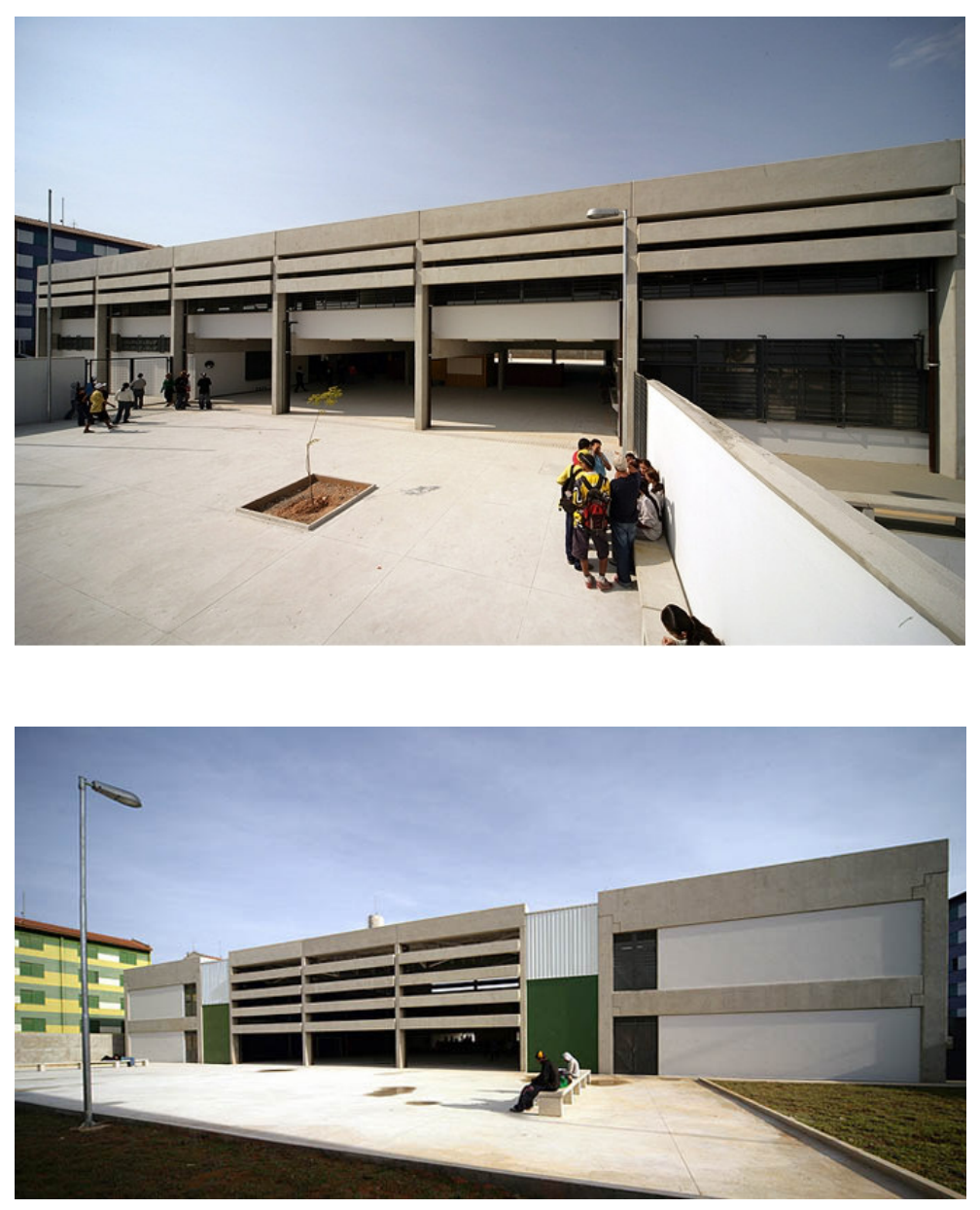

Fig. 8.2: Pátio descoberto frontal, ao lado do portão principal de acesso. (fonte: arquivo pessoal Marcos Acayaba)

Fig. 8.3: Pátio descoberto ao fundo, voltado à área de lazer coletiva da comunidade. (fonte: arquivo pessoal Marcos Acayaba) 


\section{Capítulo 8}

Escola de Ensino Fundamental Jardim Bela Vista II

Ao centro, o pátio coberto abriga a quadra poliesportiva. Sua cobertura é em telha de alumínio, sustentada por uma estrutura metálica composta por quatro treliças arqueadas.

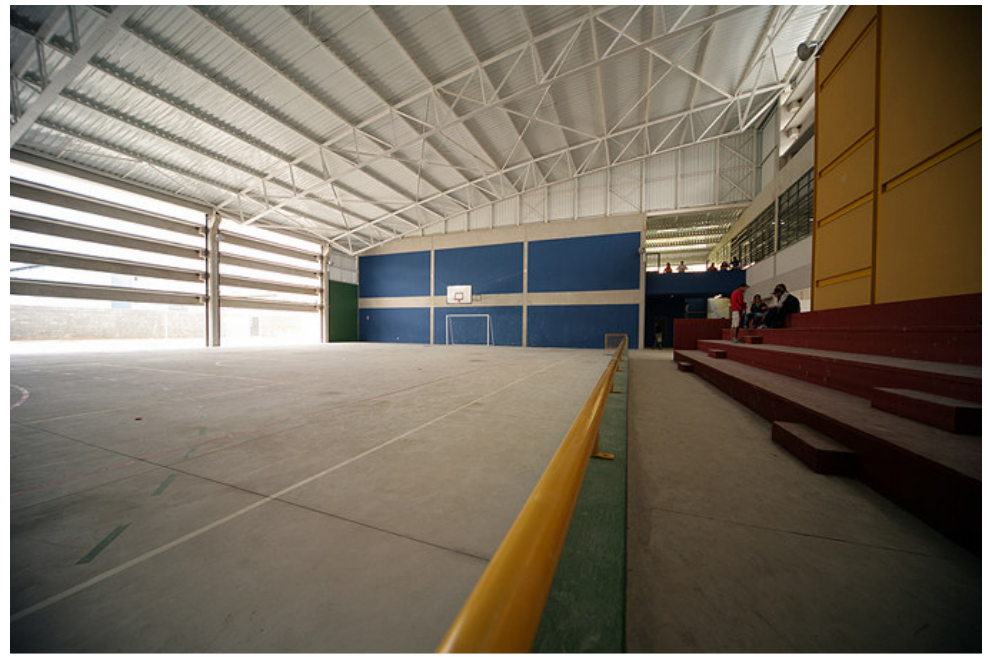

Fig. 8.4: Pátio central coberto e quadra. (fonte: arquivo pessoal Marcos Acayaba)

As treliças vencem um vão de $27,0 \mathrm{~m}$ e apóiam-se em pilares de concreto desnivelados em 4,5 m, garantindo iluminação natural durante todo o dia.

A estrutura dos blocos é toda em concreto pré-moldado, modulada de acordo com os padrões do FDE e dimensionada para edifícios de até quatro andares permitindo ampliação vertical.

No térreo, um dos blocos abriga salas de recuperação e centro de leitura; outro abriga cozinha, refeitório e grêmio; um terceiro, o maior, abriga áreas administrativas num lado e sanitários e cantina no outro; e, nos pavimentos superiores dos três blocos, localizam-se as salas de aula.
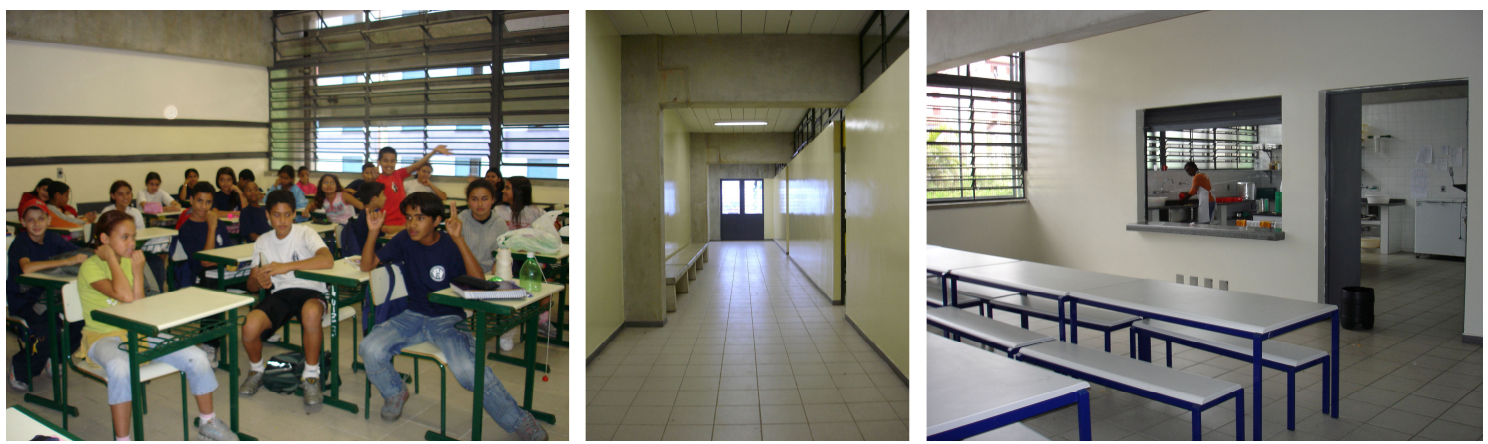

Fig. 8.5: Sala de aula, corredor de salas de aula e refeitório. (fonte: autora) 
Capítulo 8

Escola de Ensino Fundamental Jardim Bela Vista II

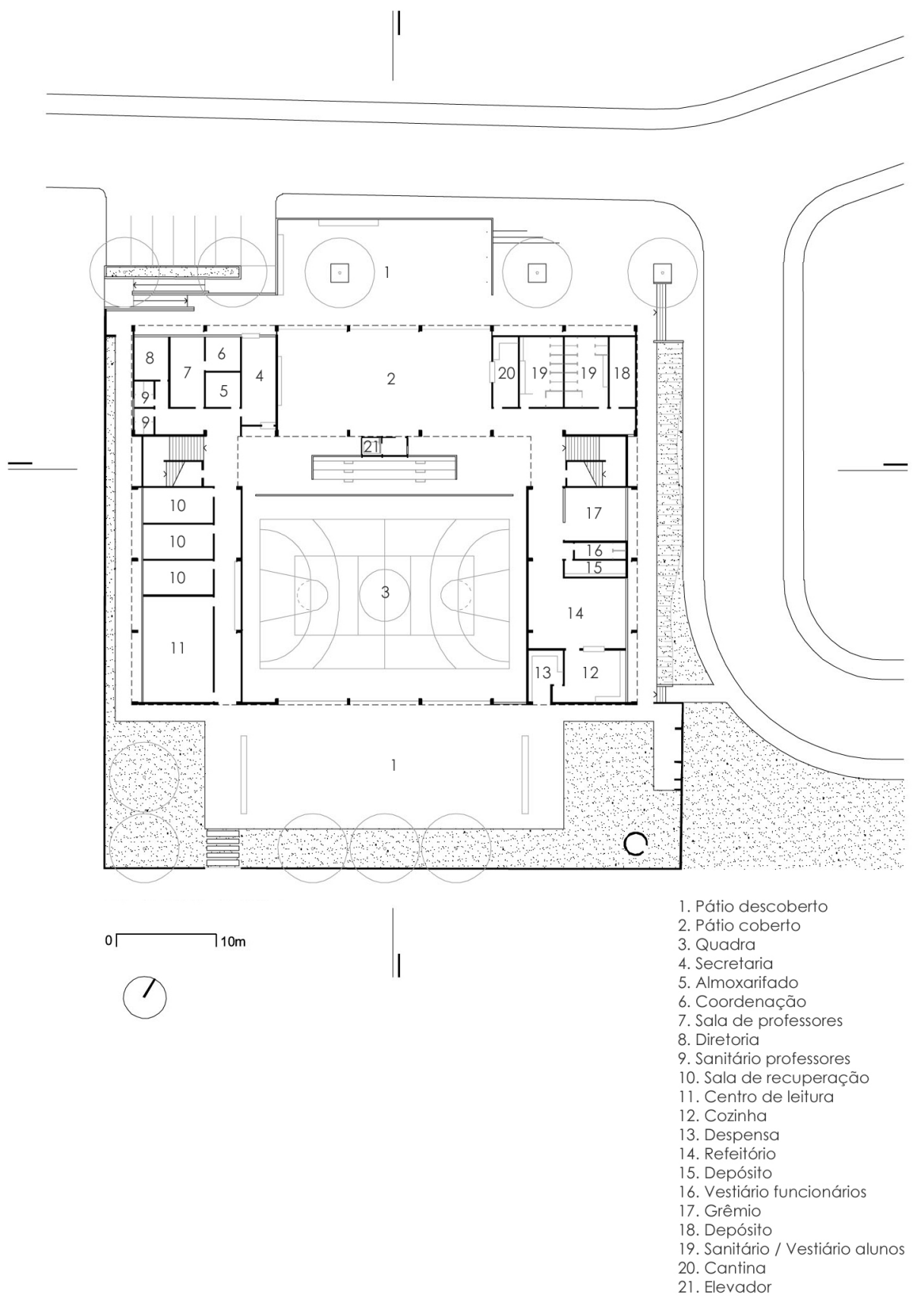

Fig. 8.6: Implantação / Planta térreo. (fonte: arquivo pessoal Marcos Acayaba) 


\section{Capítulo 8}

Escola de Ensino Fundamental Jardim Bela Vista II

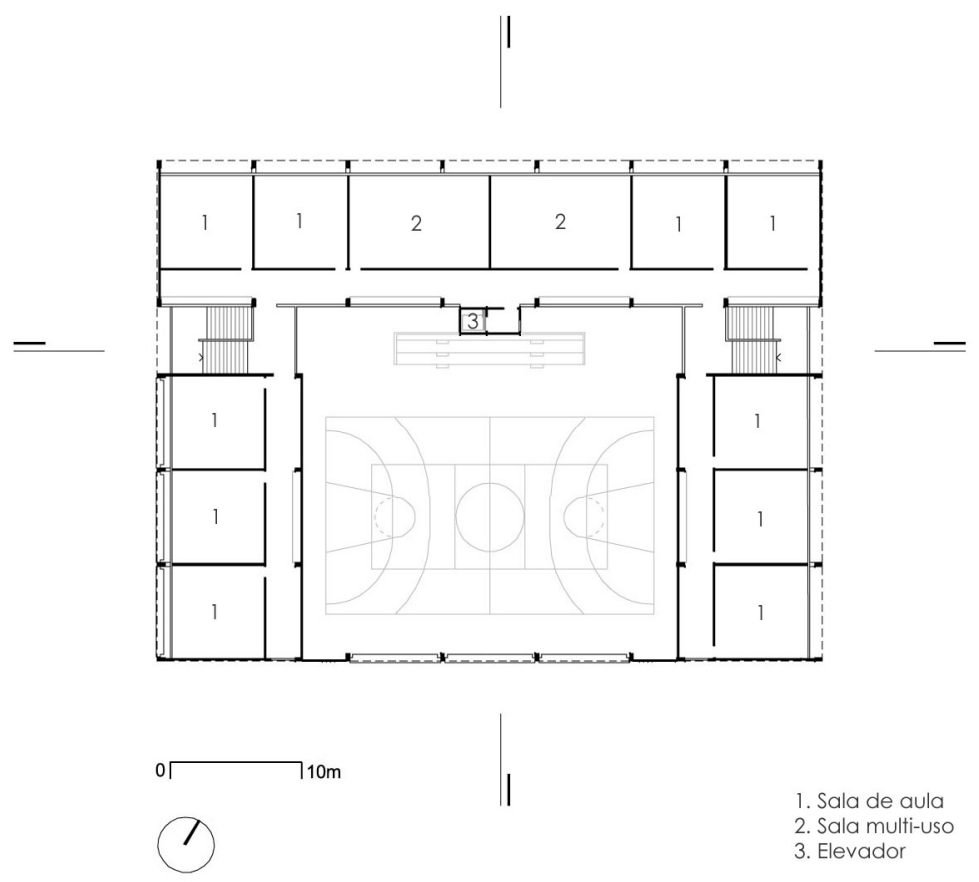

Fig. 8.7: Planta pavimento superior. (fonte: arquivo pessoal Marcos Acayaba)

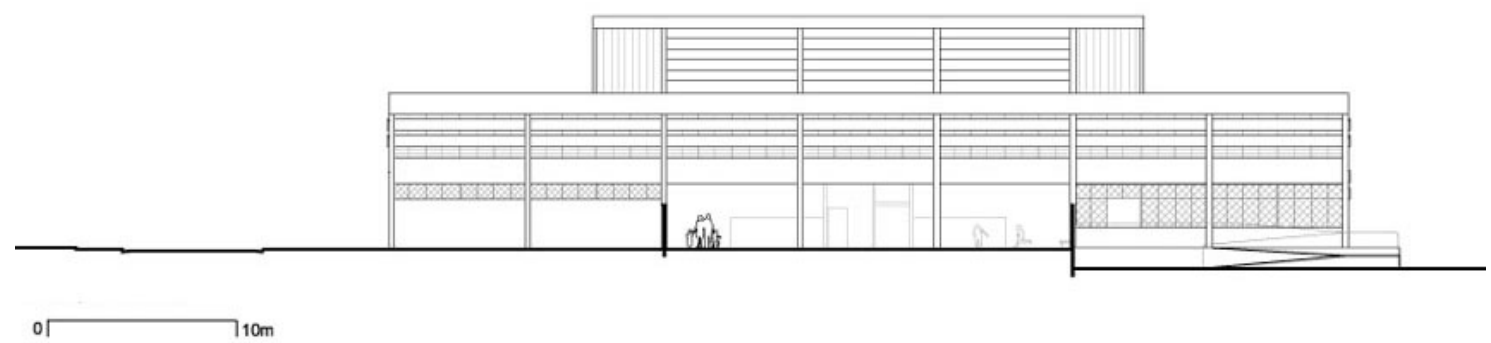

Fig. 8.8: Elevação. (fonte: arquivo pessoal Marcos Acayaba) 
Escola de Ensino Fundamental Jardim Bela Vista II

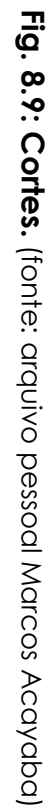
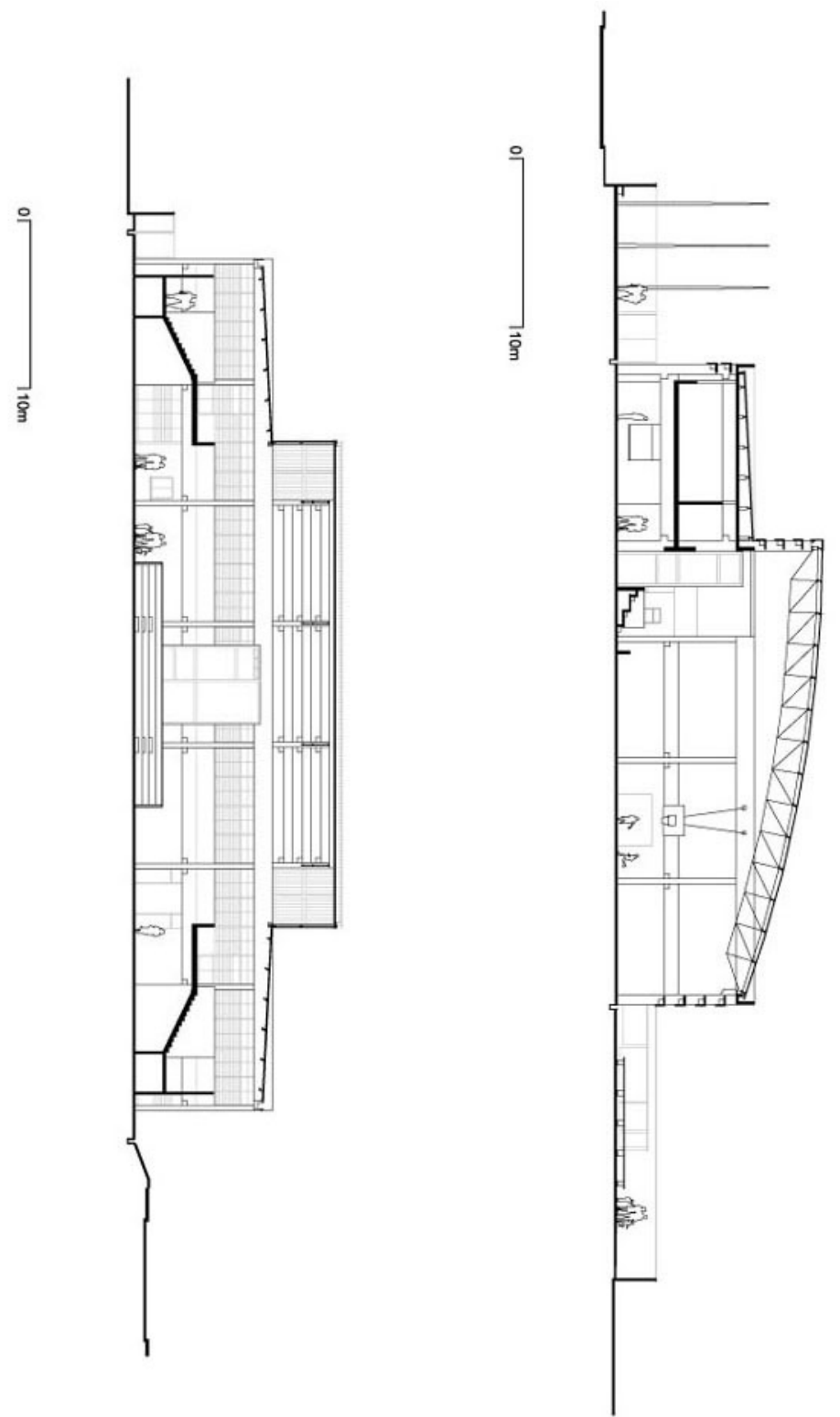


\subsection{A solução construtiva}

\section{Duas funções para elemento em concreto pré-moldado}

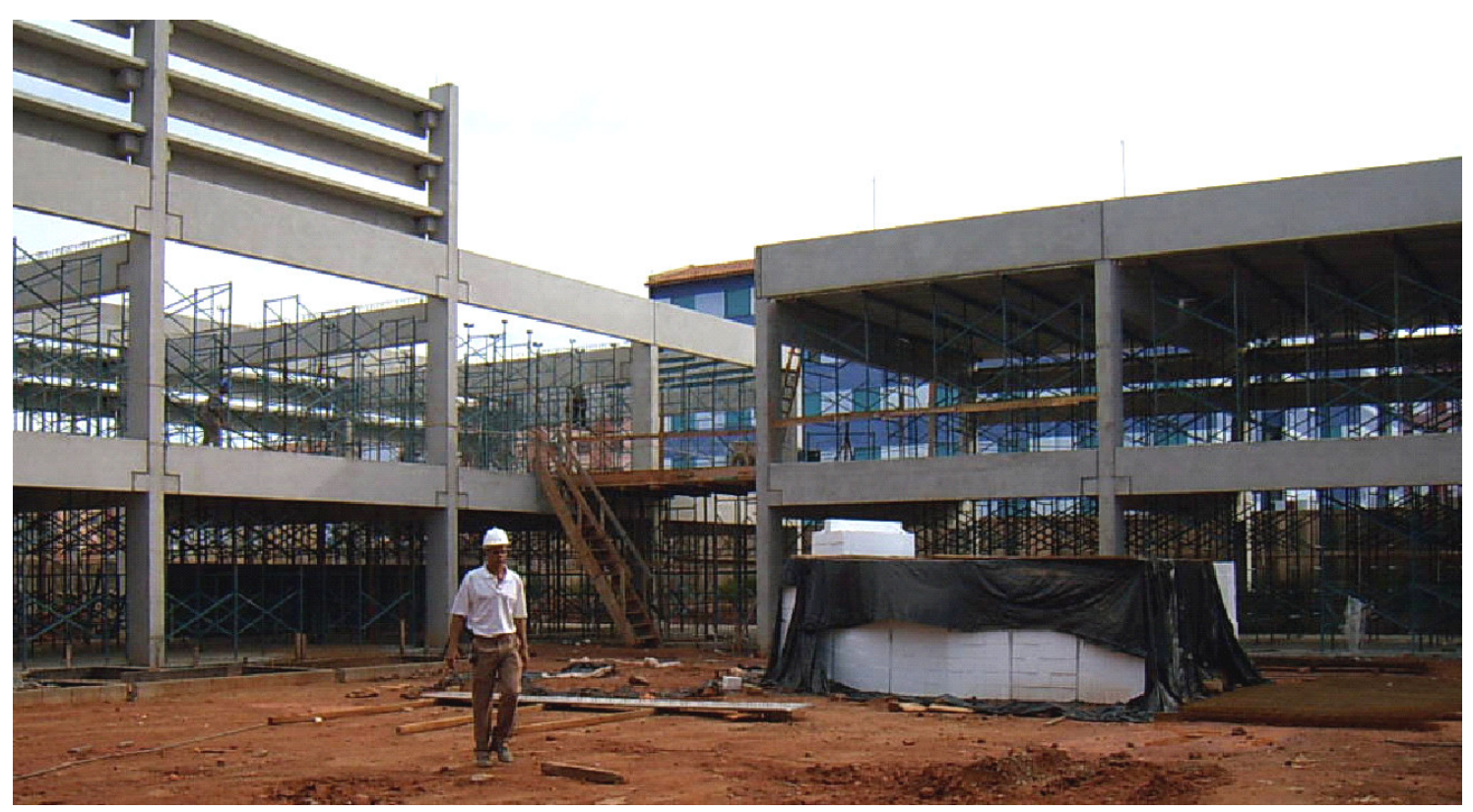

Fig. 8.10: Obra. Montagem da estrutura pré-moldada. (fonte: arquivo pessoal Marcos Acayaba)

Assim como no caso das estruturas pré-fabricadas em madeira, quando se trabalha com o concreto pré-moldado é necessário que o arquiteto tenha um bom conhecimento sobre as premissas projetuais que esse tipo de sistema construtivo estabelece.

A pré-moldagem caracteriza-se como "[...] um processo de construção em que a obra, ou parte dela, é moldada fora de seu local de utilização definitivo" (EL DEBS, 2000, P. 5).

Numa estrutura pré-moldada, para que os processos sejam otimizados, é necessária uma padronização dos componentes e, para isso, a modulação se faz necessária. Ela interfere diretamente no projeto de arquitetura, no que se refere ao dimensionamento e ao planejamento espacial do edifício. 


\section{Capítulo 8}

Escola de Ensino Fundamental Jardim Bela Vista II

Segundo El Debs (2000), diferente do concreto armado, o dimensionamento do concreto pré-moldado deve levar em consideração não só a situação final da estrutura, mas também possíveis solicitações na desmoldagem, transporte, armazenamento e montagem das peças.

As ligações entre os elementos que compõem a estrutura pré-moldada também são um diferencial em relação às estruturas moldadas no local. Elas exigem uma análise mais detalhada, pois implicam diretamente no comportamento estrutural do conjunto, podendo acarretar, por exemplo, numa maior solicitação dos elementos à flexão. Isso porque, nas estruturas de concreto pré-moldado, as ligações costumam (em edifícios de até cerca de 10,0m de altura) ser articuladas, diferente das em concreto armado (moldado in loco) em que costumam ser rígidas.
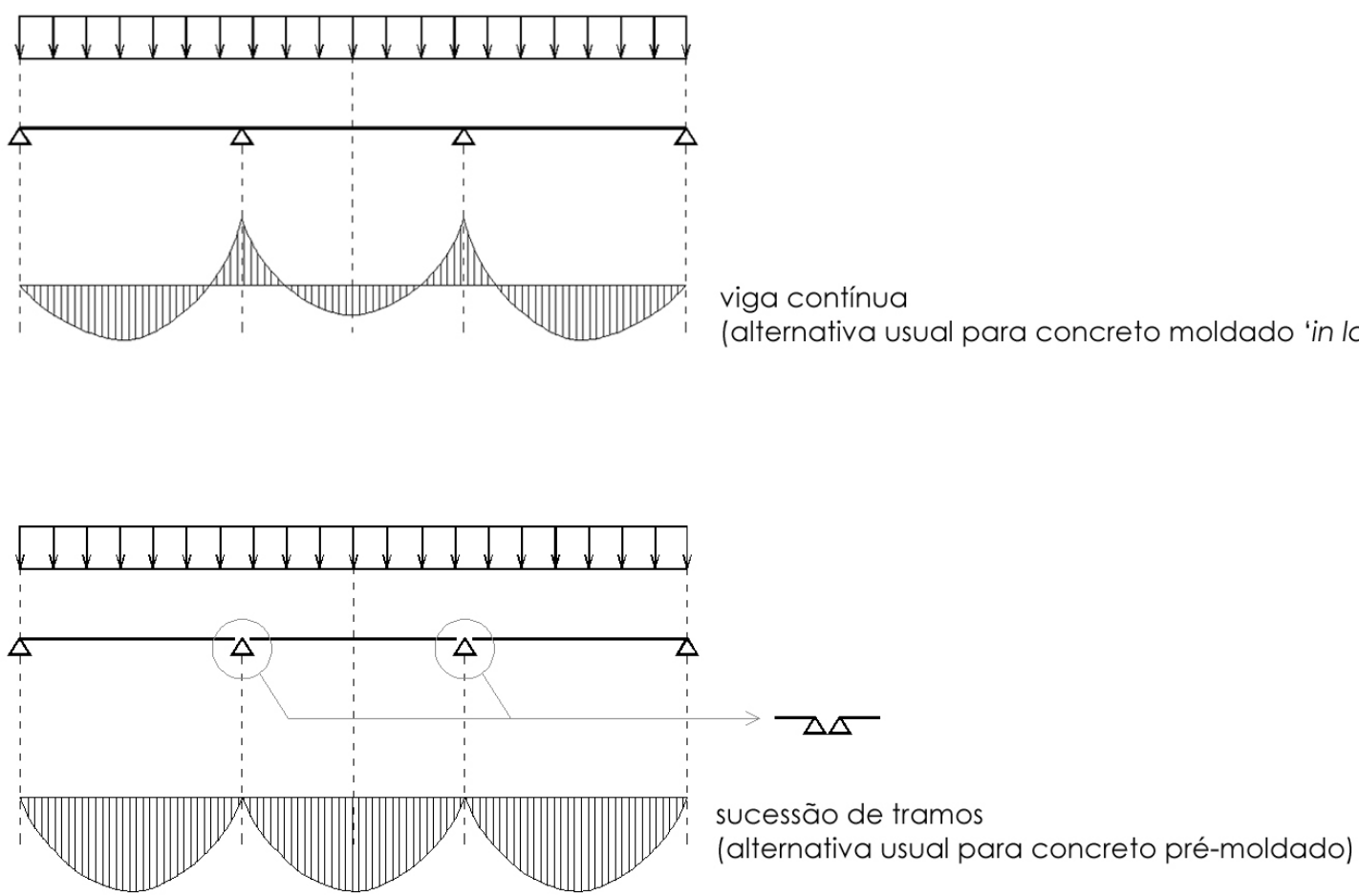

Fig. 8.11: Momentos fletores em situação de viga contínua e em sucessão de tramos, como costuma ocorrer em estruturas moldadas 'in loco' e pré-moldadas, respectivamente. (fonte: autora) 
Analisando as diferenças dos diagramas apresentados na figura 8.11, poderia se pensar que o pré-moldado é desvantajoso por seu comportamento em relação às cargas estruturais (sofre maior solicitação à flexão). Porém, segundo El Debs (2000), há outros fatores também determinantes no comportamento estrutural das duas alternativas, como as resistências dos materiais e a forma da seção transversal, por exemplo.

As ligações flexíveis também podem deixar a estrutura mais suscetível às forças horizontais que incidem na edificação. Essas forças horizontais, normalmente são originadas pela ação dos ventos e interferem somente no dimensionamento dos pilares. Normalmente os pilares, engastados na fundação, necessitam certa robustez para resistir a esses esforços, por isso sua secção costuma ser maior do que a dos pilares de uma estrutura similar feita em concreto armado, mesmo sendo o concreto utilizado nesse tipo de estrutura mais resistente: concreto moldado in loco, cerca de 25 MPa; concreto pré-moldado, por volta de 35 a 40 MPa, para esse padrão de construção (informação verbal) '.

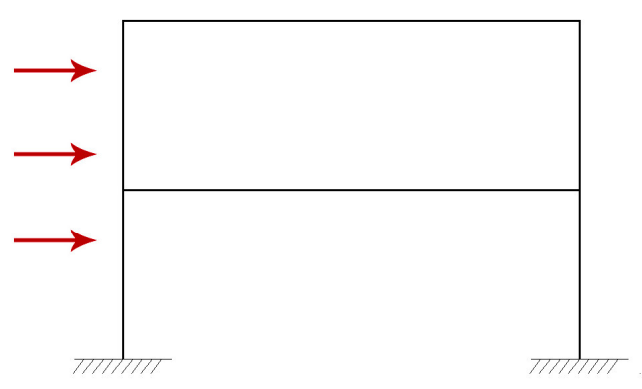

concreto armado

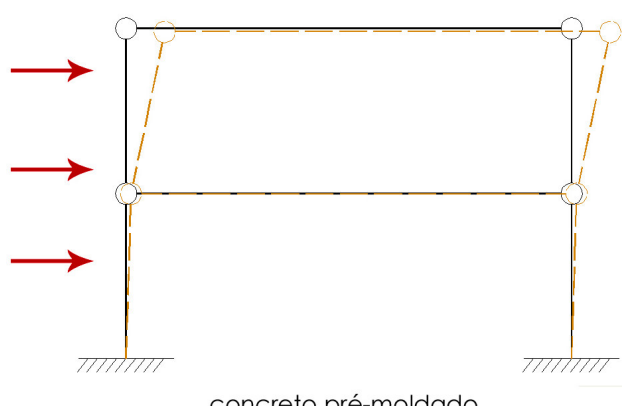

concreto pré-moldado

Fig. 8.12: Esquema estrutural. Ligações articuladas tendem a deixar a estrutura mais suscetível às forças horizontais por isso pilares tendem a ter maior seção para garantir a rigidez do conjunto. (fonte: autora)

No entanto, numa estrutura, devem-se levar em conta tanto os aspectos estruturais quanto os construtivos. Em determinadas situações, as vantagens construtivas do sistema pré-fabricado se sobressaem. Ele se torna mais vantajoso quando se considera a facilidade de montagem, o tempo de

\footnotetext{
1 Informação cedida pelo Professor Dr. Mounir Kalil El Debs em atendimento pessoal.
} 


\section{Capítulo 8}

Escola de Ensino Fundamental Jardim Bela Vista II

execução, a limpeza da obra etc. É o caso das escolas produzidas pelo FDE, realizadas em grande número no estado de São Paulo, que adotam um sistema padronizado para o projeto e para a construção.

Numa construção em pré-moldado, praticamente se elimina a necessidade de fôrmas e cimbramentos. O tempo de execução e a quantidade de resíduos gerada também costumam ser bem menores, pelo fato das peças chegarem prontas, sendo somente montadas no local da obra. As peças são içadas por meio de guindastes, e/ou gruas, e encaixadas em seu devido lugar.

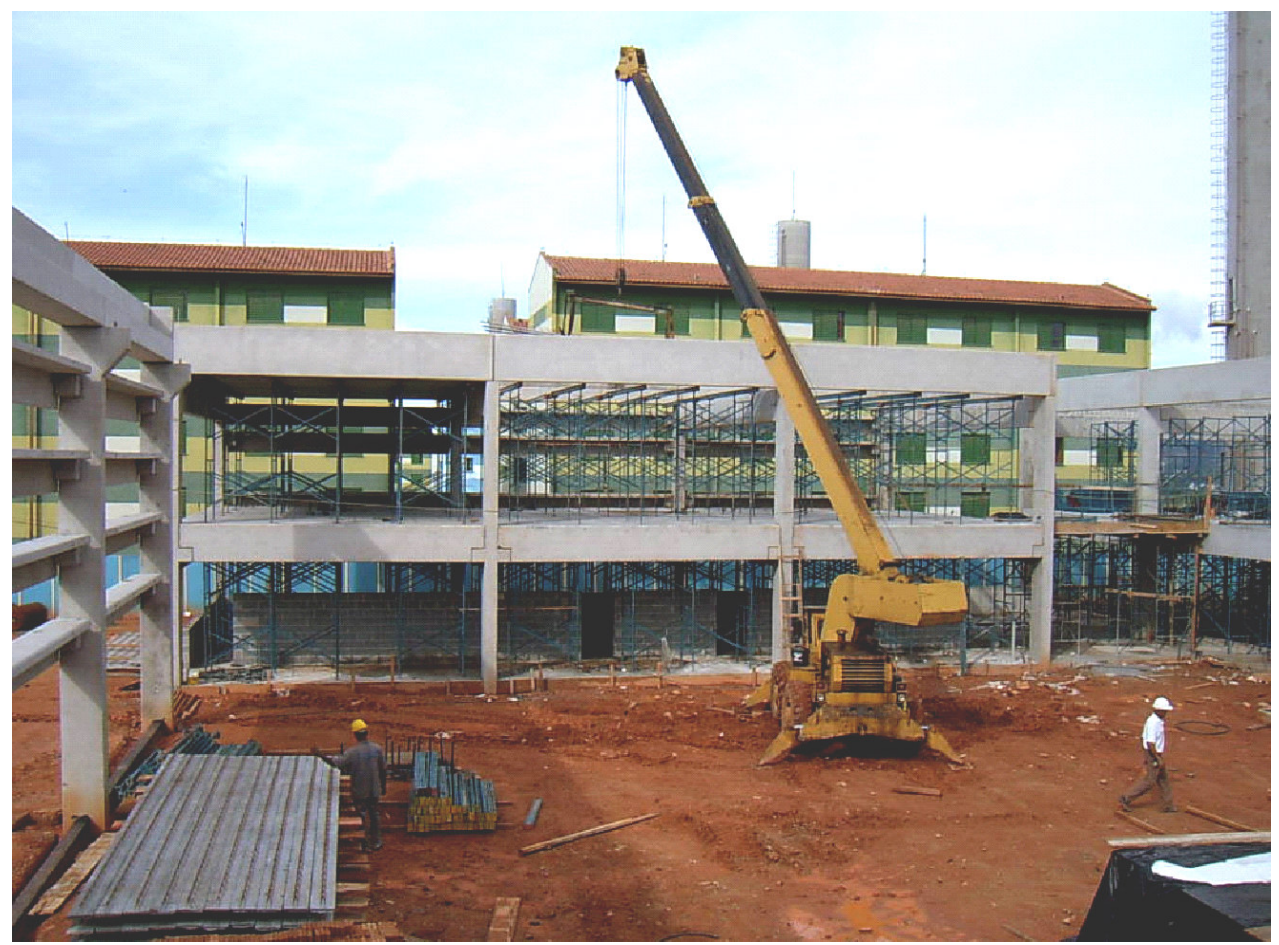

Fig. 8.13: Içamento das peças por guindaste. (fonte: arquivo pessoal Marcos Acayaba)

O arquiteto, ao projetar prevendo estrutura em concreto pré-moldado, deve também levar em consideração que ela não pode receber revestimento, portanto deverá sempre permanecer aparente. Nesse caso, ele pode ou não tirar partido disso.

Nesse projeto, um elemento se destaca devido ao seu desenvolvimento, ocorrido num diálogo entre arquiteto e engenheiro. Uma única peça em concreto pré-moldado detém dupla função: a de brise e de travamento horizontal da estrutura. 
Capítulo 8

Escola de Ensino Fundamental Jardim Bela Vista II
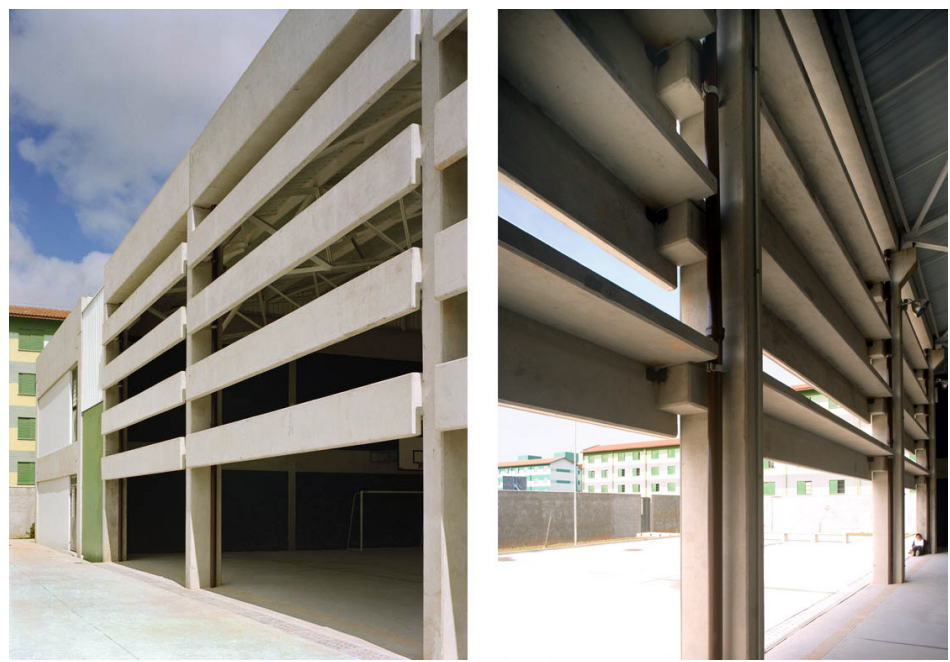

Fig. 8.14: Elemento em concreto pré-moldado em face externa e no interior do edifício. (fonte: arquivo pessoal Marcos Acayaba)

Com um desenho diferenciado e um custo reduzido, essa solução evitou o uso de elementos metálicos de proteção solar (o mais utilizado nas escolas do FDE recentemente construídas), que deterioram com facilidade e exigem manutenção freqüente.

Esse elemento nas fachadas contribuiu para uma linguagem marcada pela horizontalidade, dando ao edifício um destaque em meio à paisagem caracterizada pelos conjuntos do CDHU.

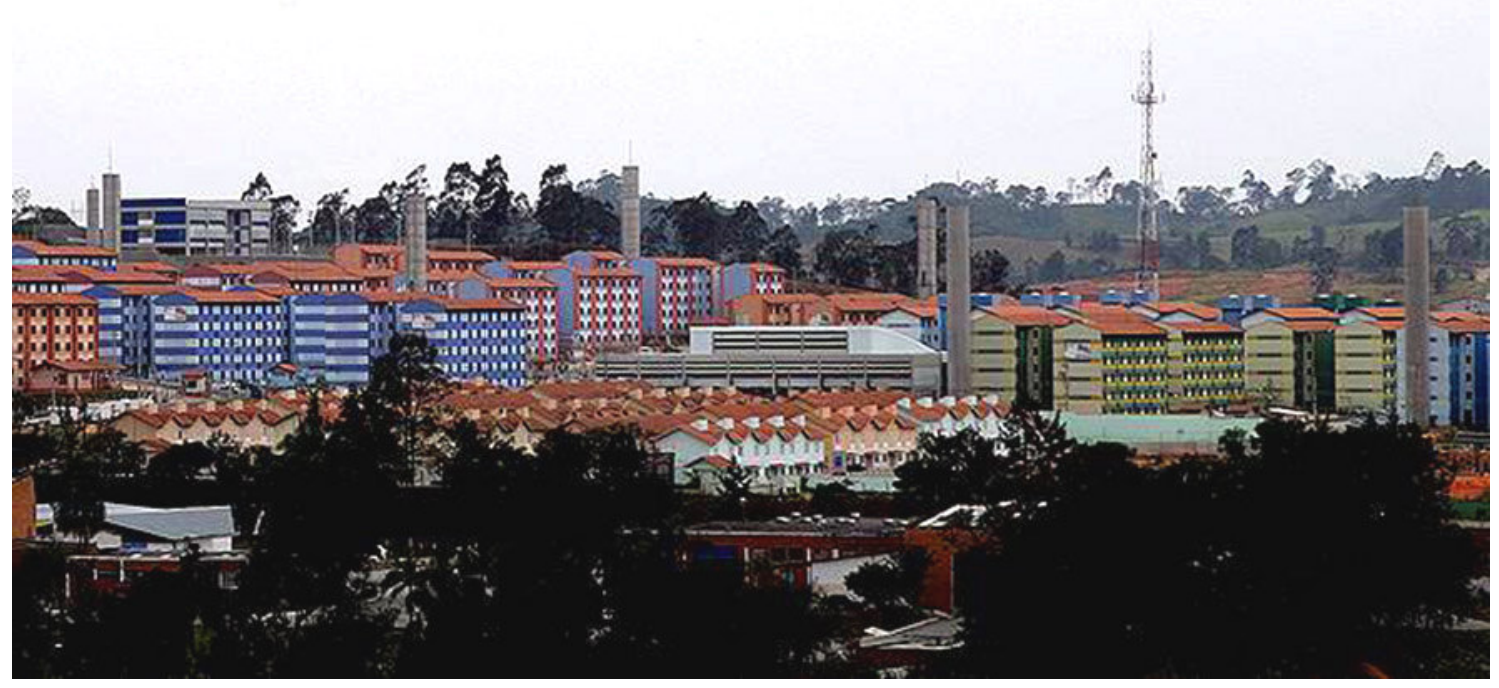

Fig. 8.15: Localização em meio a conjuntos habitacionais do CDHU. (fonte: arquivo pessoal Marcos Acayaba) 


\section{Capítulo 8}

Escola de Ensino Fundamental Jardim Bela Vista II

Segundo Acayaba (2007), o processo de desenvolvimento dessa solução ocorreu a partir de simulações de insolação realizadas em Archicad.

Uma peça padrão de concreto pré-moldado, a viga calha, foi adotada no primeiro estudo. Após uma conversa com o engenheiro de estruturas, o arquiteto decidiu adotar uma peça mais esbelta, considerando o vão, a carga, o peso próprio da peça e o travamento de estrutura.

O estudo de insolação, segundo Acayaba (2007), foi realizado considerando os horários de aula: das oito da manhã às cinco da tarde, dispensando o período de férias de verão (dezembro e janeiro), o mais crítico, por apresentar insolação numa angulação muito baixa.

Ao final, chegou-se a uma peça de $60,0 \mathrm{~cm} \times 60,0 \mathrm{~cm}$, com 12,0 cm de espessura, como mostram as figuras a seguir.

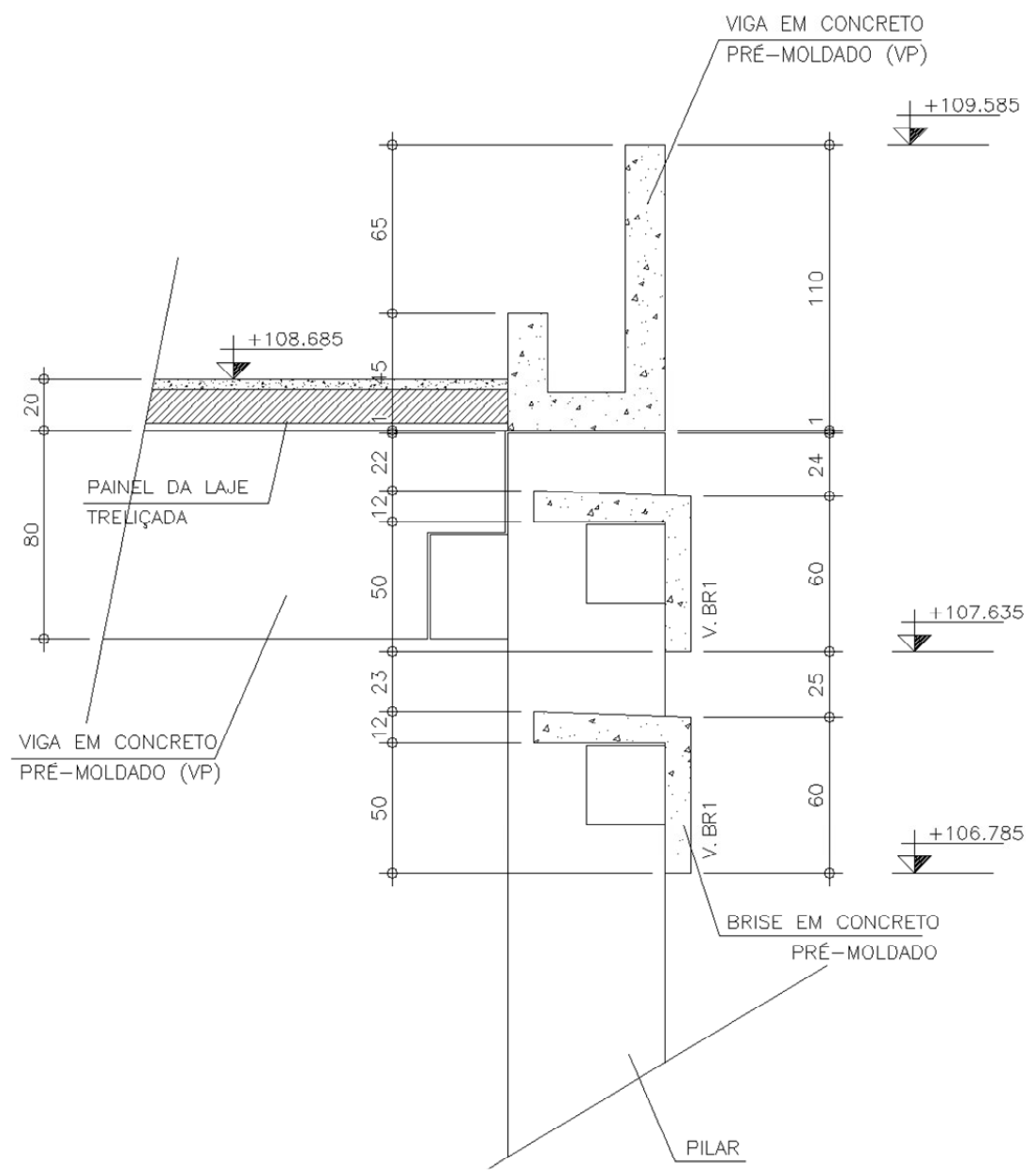

Fig. 8.16: Detalhe em corte dos brises em concreto pré-moldado. (fonte: arquivo Ruy Bentes Engenharia de Estruturas) 
Capítulo 8

Escola de Ensino Fundamental Jardim Bela Vista II

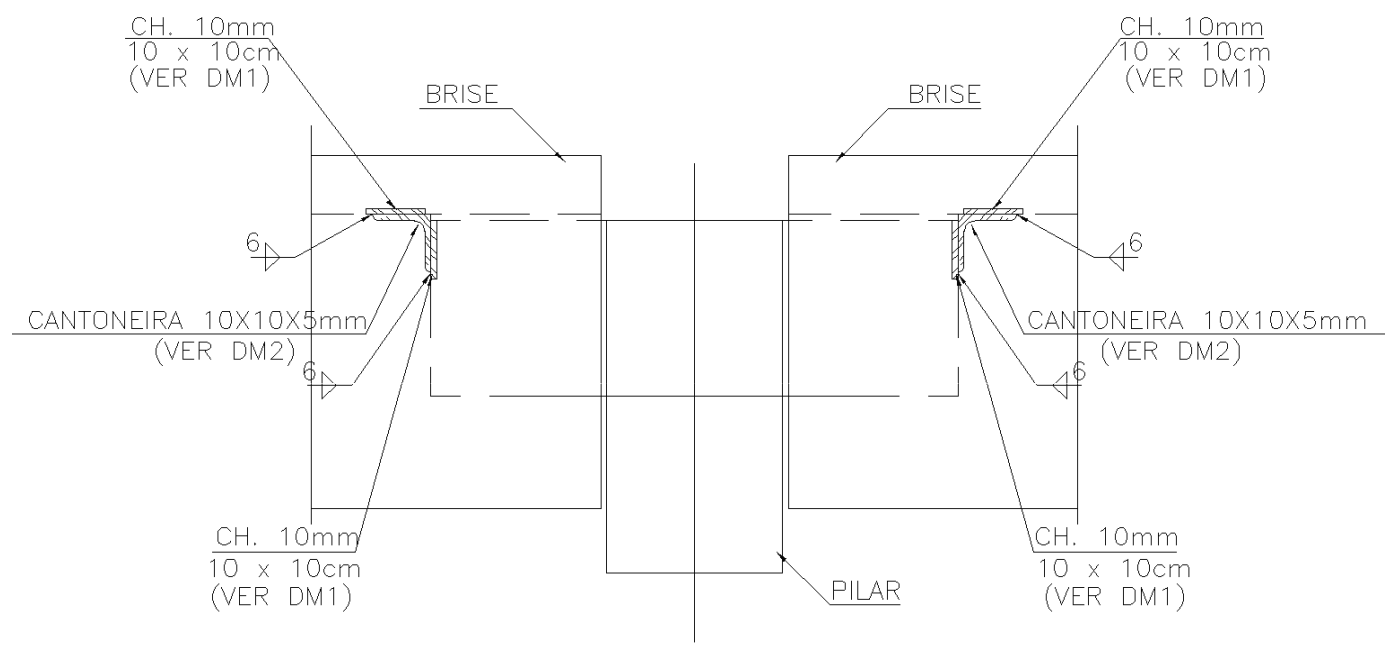

Fig. 8.17: Detalhe em planta dos brises em concreto pré-moldado. (fonte: arquivo Ruy Bentes Engenharia de Estruturas)

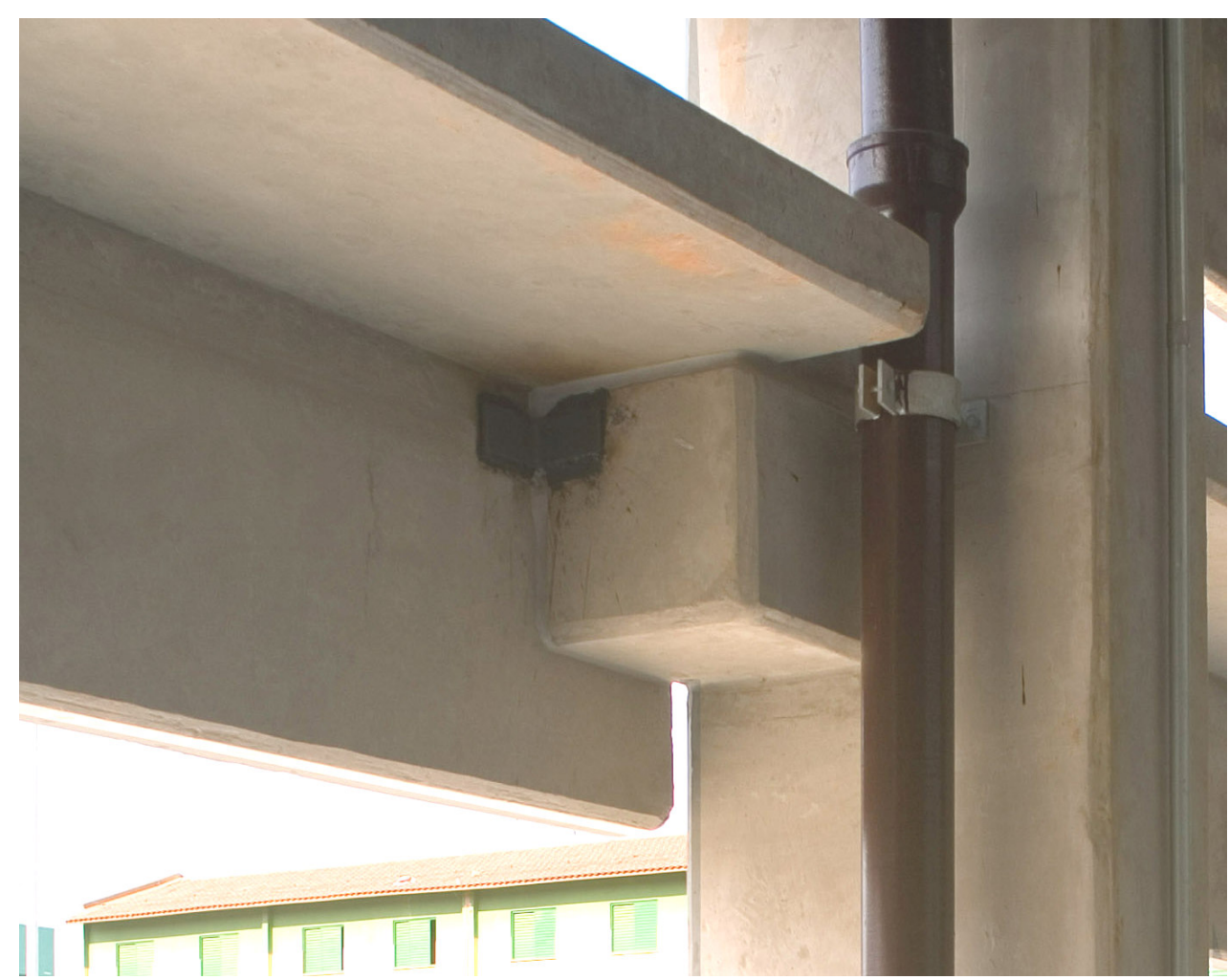

Fig. 8.18: Console de apoio e fixação por cantoneira metálica. (fonte: arquivo pessoal Marcos Acayaba - editada pela autora) 


\section{Capítulo 8}

Escola de Ensino Fundamental Jardim Bela Vista II

De acordo com o engenheiro Bentes (2007), da Ruy Bentes Engenharia de Estruturas S/A, empresa responsável pelo projeto estrutural, a cantoneira metálica chumbada à estrutura impede a rotação da peça.

Entre a peça e o console há uma camada de elastômero (neoprene), um material semelhante a uma 'borracha', que diminui $O$ atrito entre os componentes da estrutura, evitando o desgaste das peças.

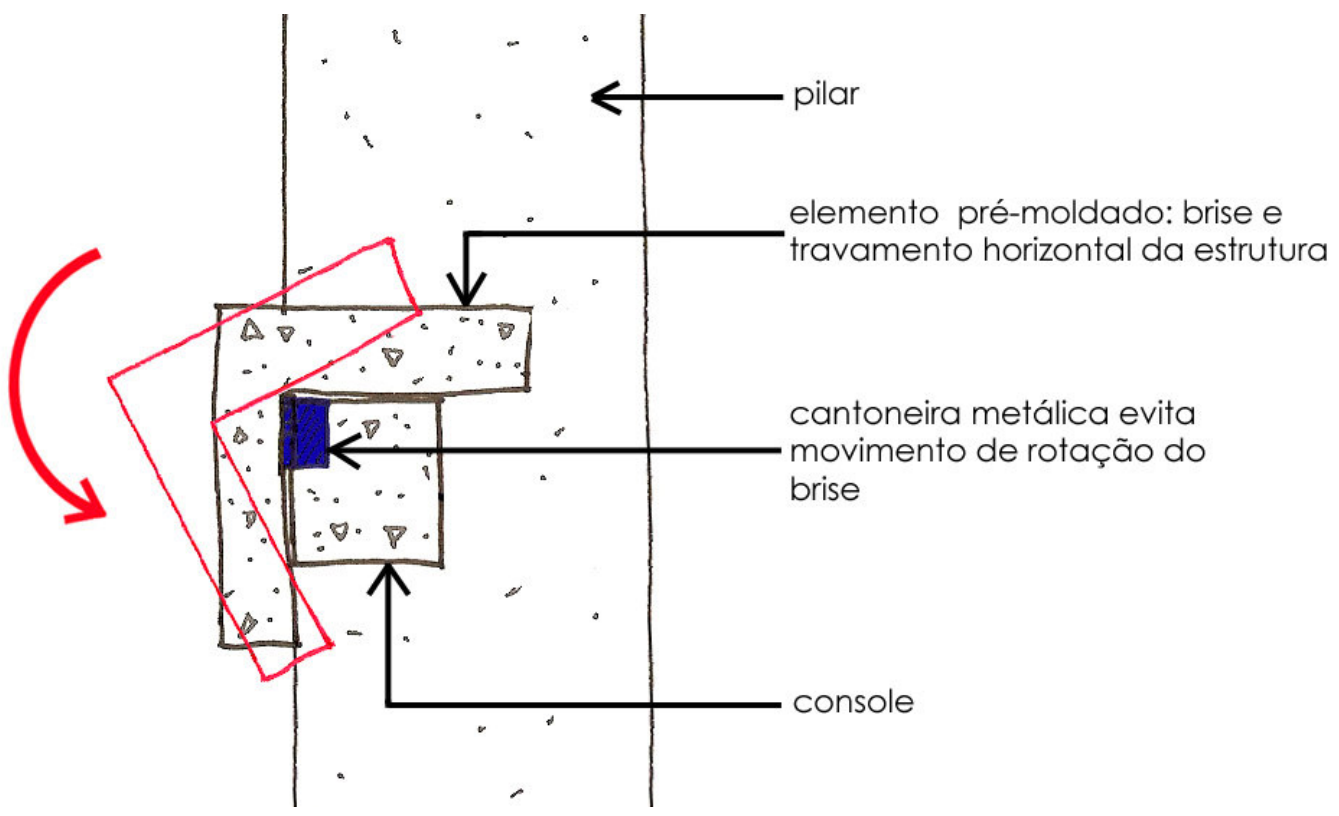

Fig. 8.19: Esquema ilustra movimento de rotação que a peça poderia sofrer na ausência da peça metálica. (fonte: autora)

Numa estrutura moldada in loco, dificilmente se utilizaria um perfil em L como o dessa solução, pela dificuldade de montagem das fôrmas e desmoldagem. No sistema em concreto pré-moldado cada peça é moldada isoladamente umas das outras na fábrica, propiciando ao arquiteto maior liberdade no desenho dos perfis estruturais, que possuem formatos e medidas padrão, mas que, como ocorreu neste caso, podem sofrer modificações em função de uma necessidade de projeto.

É possível se criar perfis com desenho diferenciado, contanto que haja uma repetição dessa peça para que se compense os custos de fôrma. 


\subsection{Considerações sobre o projeto}

Nesse projeto, assim como nos realizados em estrutura pré-fabricada em madeira, a resolução das questões estruturais e de conforto e o diálogo com outros profissionais, foram determinantes na linguagem final do edifício. Porém, não foi preciso desenvolver novas técnicas construtivas para se resolver as necessidades demandadas pelo terreno ou pelo programa, como naqueles casos. Também porque, o sistema construtivo adotado pelo FDE é padronizado. Ao ser contratado, o arquiteto recebe instruções de projeto e deve seguir as normas pré-estabelecidas de: modulação e dimensionamento de ambientes, programa de necessidades, sistema construtivo etc. Essas normas são explicadas em manuais (ver FUNDAÇÃO PARA O DESENVOLVIMENTO DA EDUCAÇÃO, 1994), os quais muitas vezes são criticados por se dizer que limitam a capacidade de expressão do arquiteto.

No entanto, pode-se tirar partido disso. Cabe ao arquiteto criar soluções que se justifiquem não somente pela estética, mas também pela funcionalidade, como é o caso de Acayaba nesse projeto, que tira partido das possibilidades do material, o concreto pré-moldado, e cria um elemento em que se fundem funções relacionadas à estética, à estrutura e ao conforto térmico. 


\section{Capítulo 8}

Escola de Ensino Fundamental Jardim Bela Vista II

\subsection{Ficha técnica - Escola de Ensino Fundamental Jd. Bela Vista II}

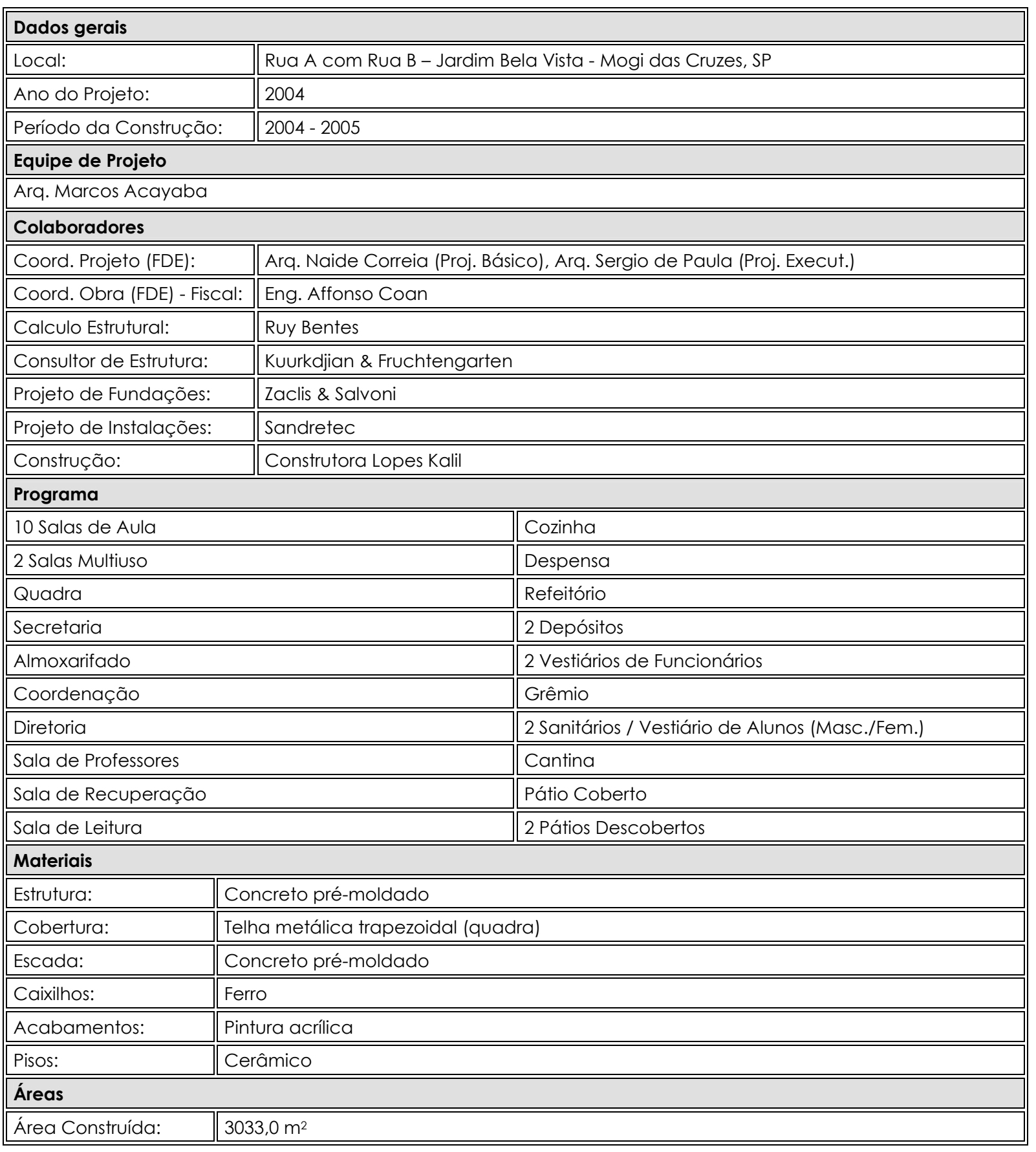


Capítulo 9

Vila Butantã

\section{CAPÍTULO 9:}

VILA BUTANTÃ (São Paulo - SP, 1998-2004)

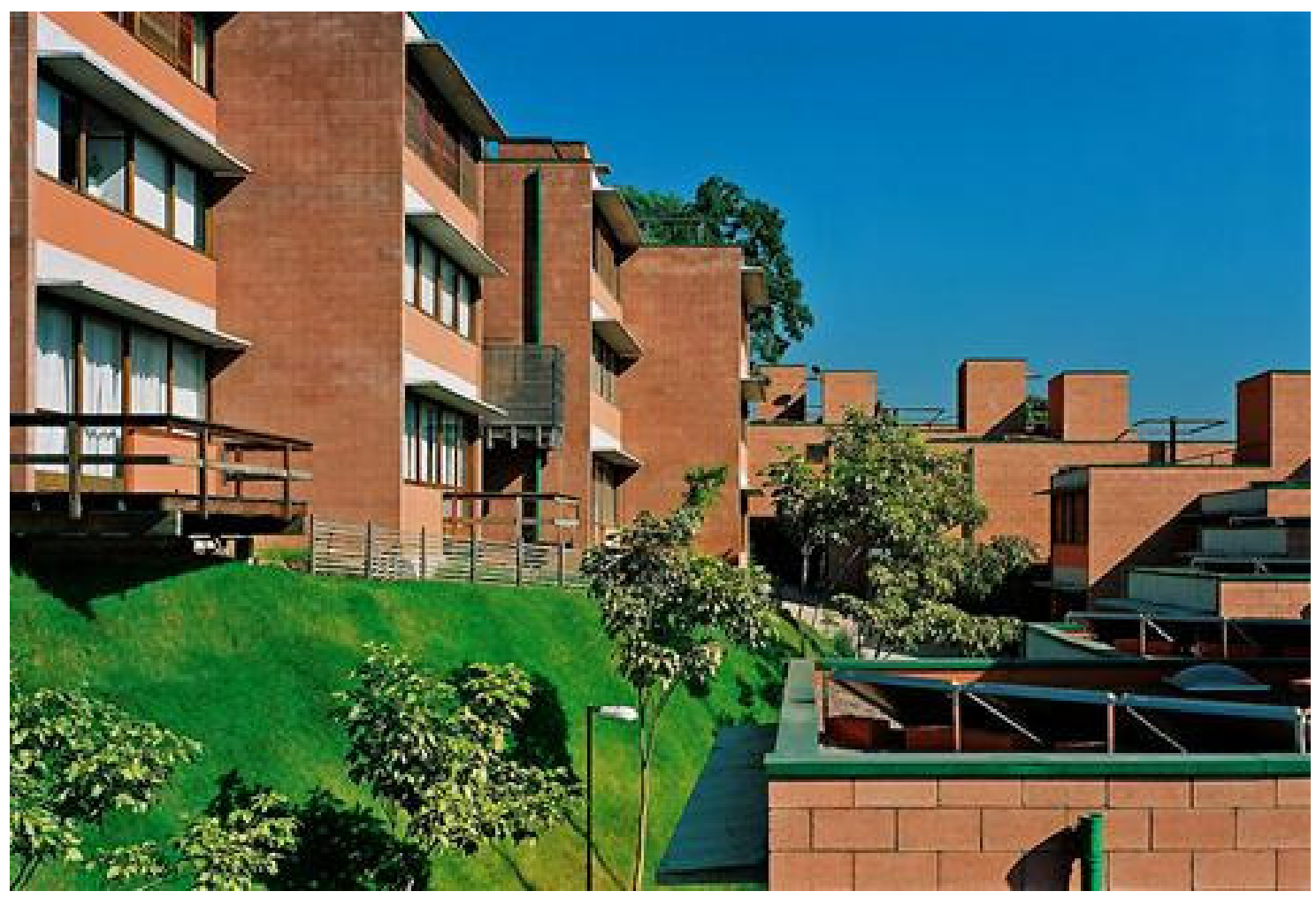

Fig. 9.1: Vista geral. Vila Butantã. (fonte: arquivo pessoal Marcos Acayaba) 
Capítulo 9

Vila Butantã

\subsection{O projeto}

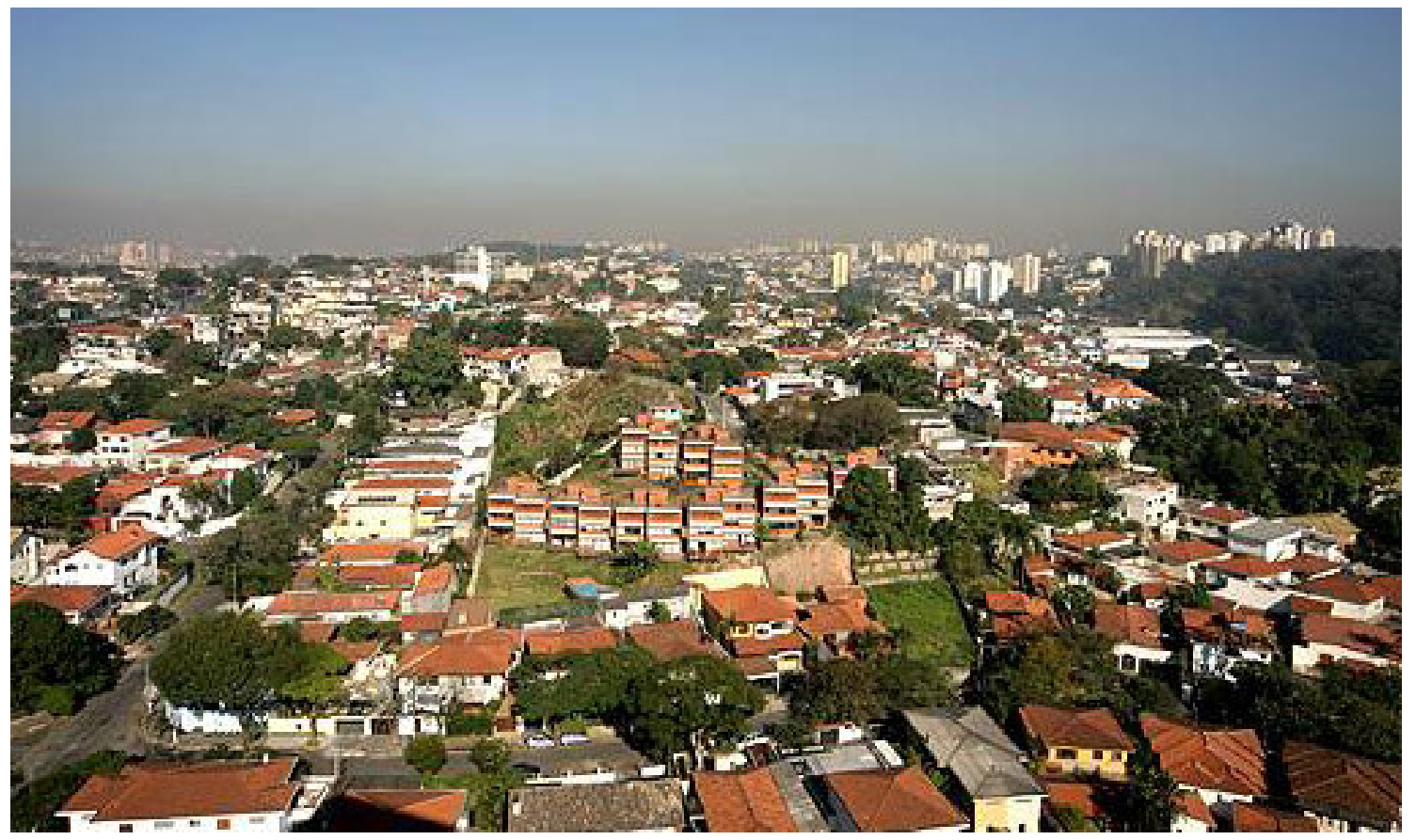

Fig. 9.2: Localização no bairro do Butantã, São Paulo-SP. (fonte: arquivo pessoal Marcos Acayaba)

Atualmente, o desenvolvimento de muitas técnicas e tecnologias no setor da construção vem ocorrendo em função da redução de custos, sem considerar as necessidades naturais humanas. $O$ valor de mercado se sobrepõe ao valor técnico e espacial (de uso) (MASCARÓ, L., 1990b).

Localizada no bairro do Butantã, na cidade de São Paulo, a Vila Butantã constitui-se por um conjunto de dezesseis residências unifamiliares, projetadas e construídas, com propósitos empreendedores, por Marcos Acayaba e Hélio Olga de Souza Júnior.

Nesse projeto, a parceria entre $o$ arquiteto e $O$ engenheiro desde $a$ idealização do empreendimento conferiu ao projeto um caráter exploratório das melhores soluções construtivas e espaciais em função das condições de relevo, solo e insolação, numa proposta diferenciada em relação aos empreendimentos imobiliários do setor. 
Capítulo 9

Vila Butantã

Acayaba revelou que ele e Hélio trabalharam juntos desde a escolha do terreno, passando por todo desenvolvimento espacial e construtivo e execução da obra (informação verbal)' .

Todas as casas foram implantadas de modo a favorecer o lazer coletivo e se adaptar ao relevo do terreno, de cerca de $4500 \mathrm{~m}^{2}$, grande declividade e pequena cobertura vegetal (segundo o arquiteto, todas as árvores foram preservadas).

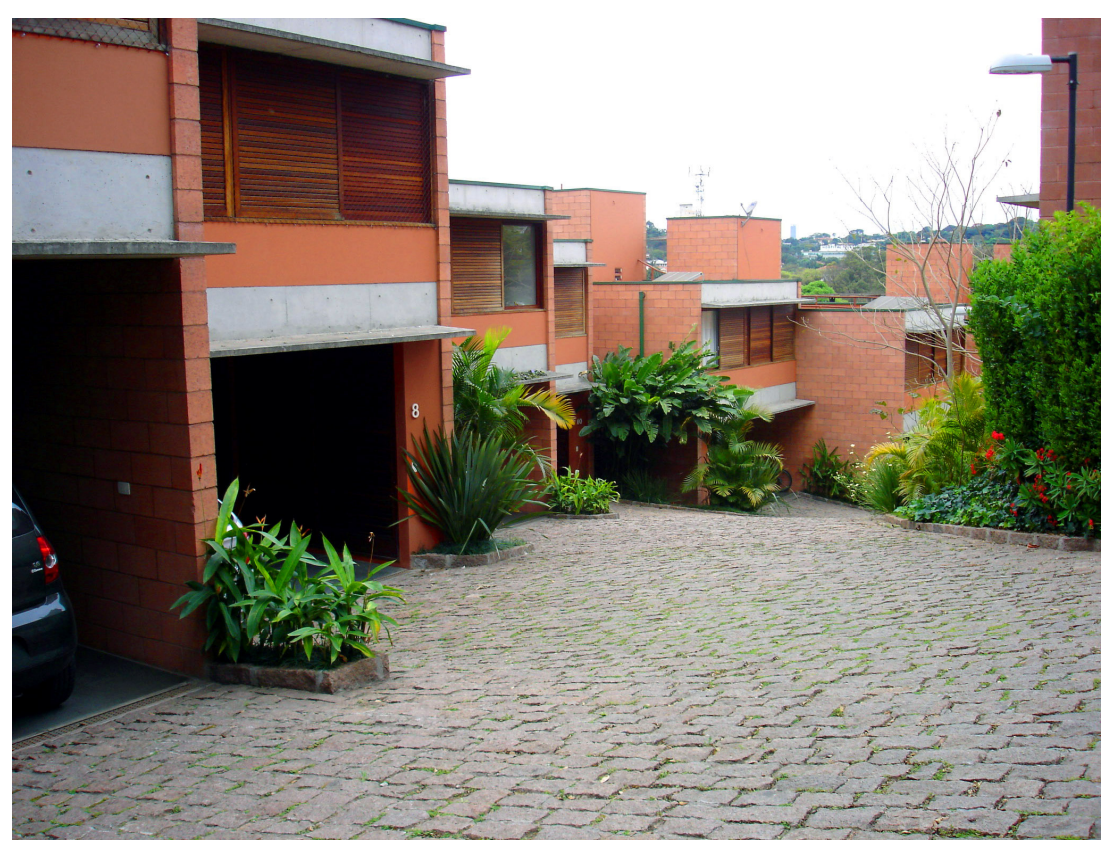

Fig. 9.3: Rua interna de acesso às (fonte: autora)
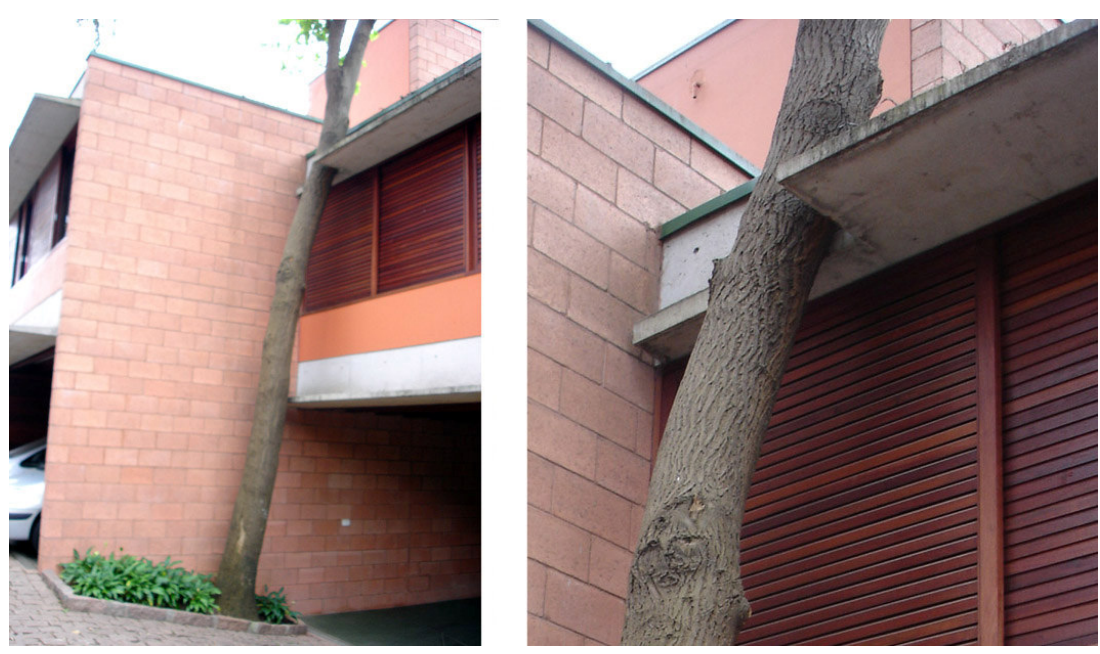

Fig. 9.4: Recorte no beiral para evitar remoção da árvore. (fonte: autora)

\footnotetext{
1 Informação dada por Marcos Acayaba em visita à Vila Butantã.
} 
Capítulo 9

Vila Butantã

Duas a duas, as casas se espalham pelo terreno formando duas fileiras, uma próximo ao nível da rua, de quatro casas, e uma mais a baixo, de 12 casas.

Na área mais baixa do terreno localiza-se a área de lazer, composta por um campinho de futebol, uma piscina e um salão de festas.

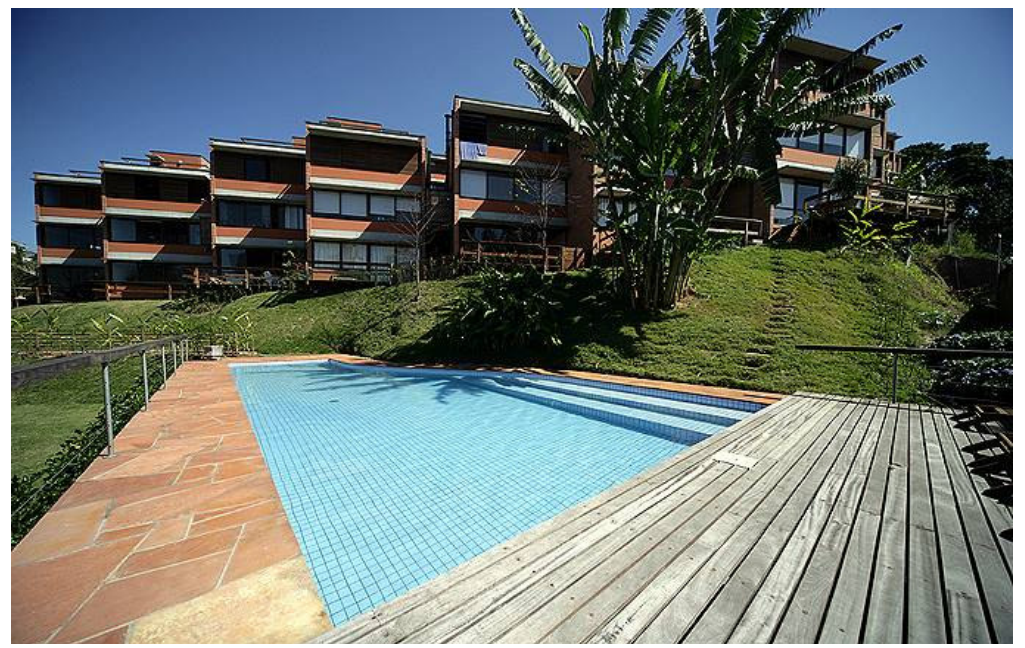

Fig. 9.5: Vista da piscina.

(fonte: arquivo pessoal Marcos Acayaba)

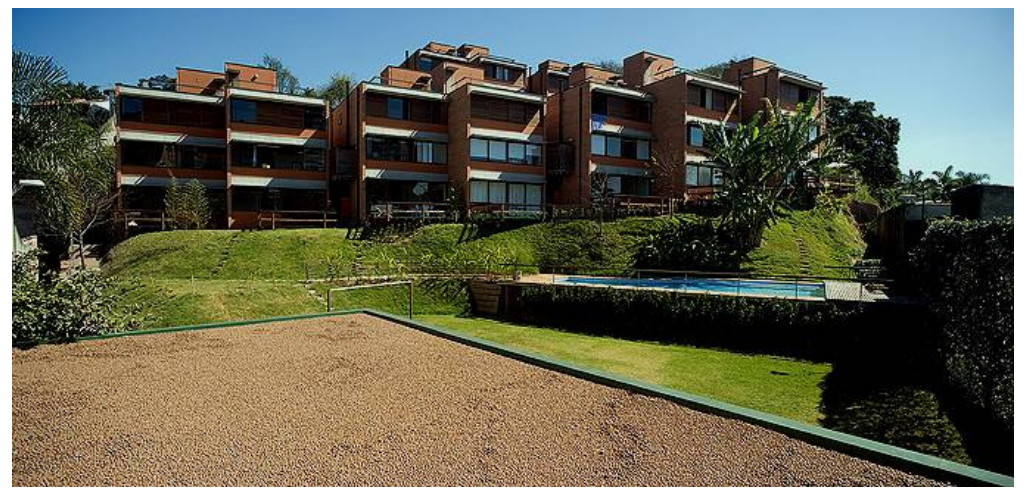

Fig. 9.6: Vista a partir da cobertura do salão de festas, área de lazer coletivo. (fonte: arquivo pessoal Marcos Acayaba)

As casas, de $174,0 \mathrm{~m}^{2}$, possuem três pavimentos, mais cobertura e possuem pequenas variações resultando em quatro tipologias.

O acesso principal se dá pelo piso intermediário, onde se localizam garagem, cozinha, sala de refeições e área de serviço. No piso inferior, situam-se sala, escritório (em algumas tipologias) e terraço. E no superior, os quartos.

Na cobertura, a laje funciona como um terraço, que dá vista à área de lazer coletivo e ao bairro do Butantã. 
Capítulo 9

Vila Butantã

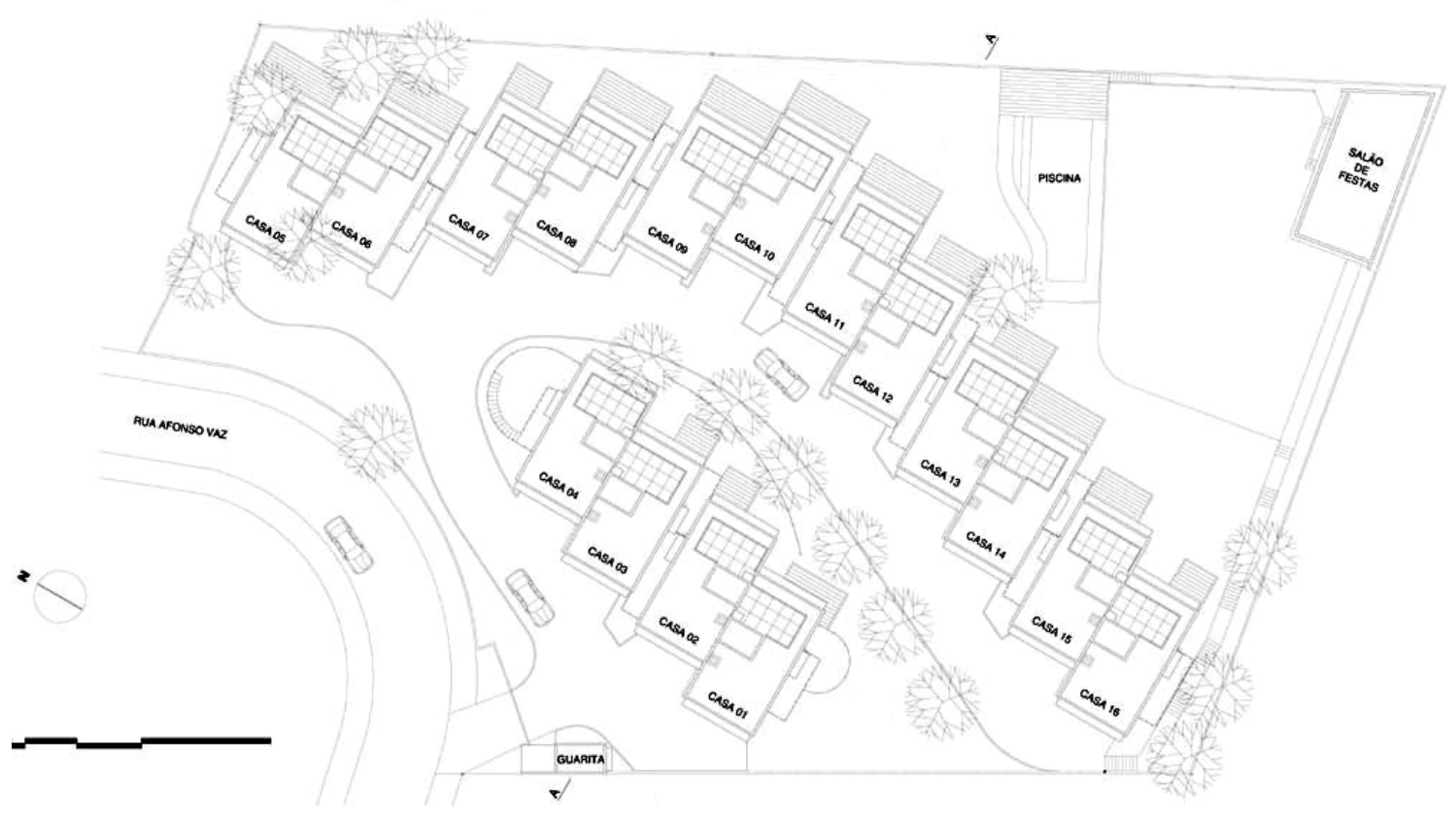

Fig. 9.7: Implantação. (fonte: arquivo pessoal Marcos Acayaba)

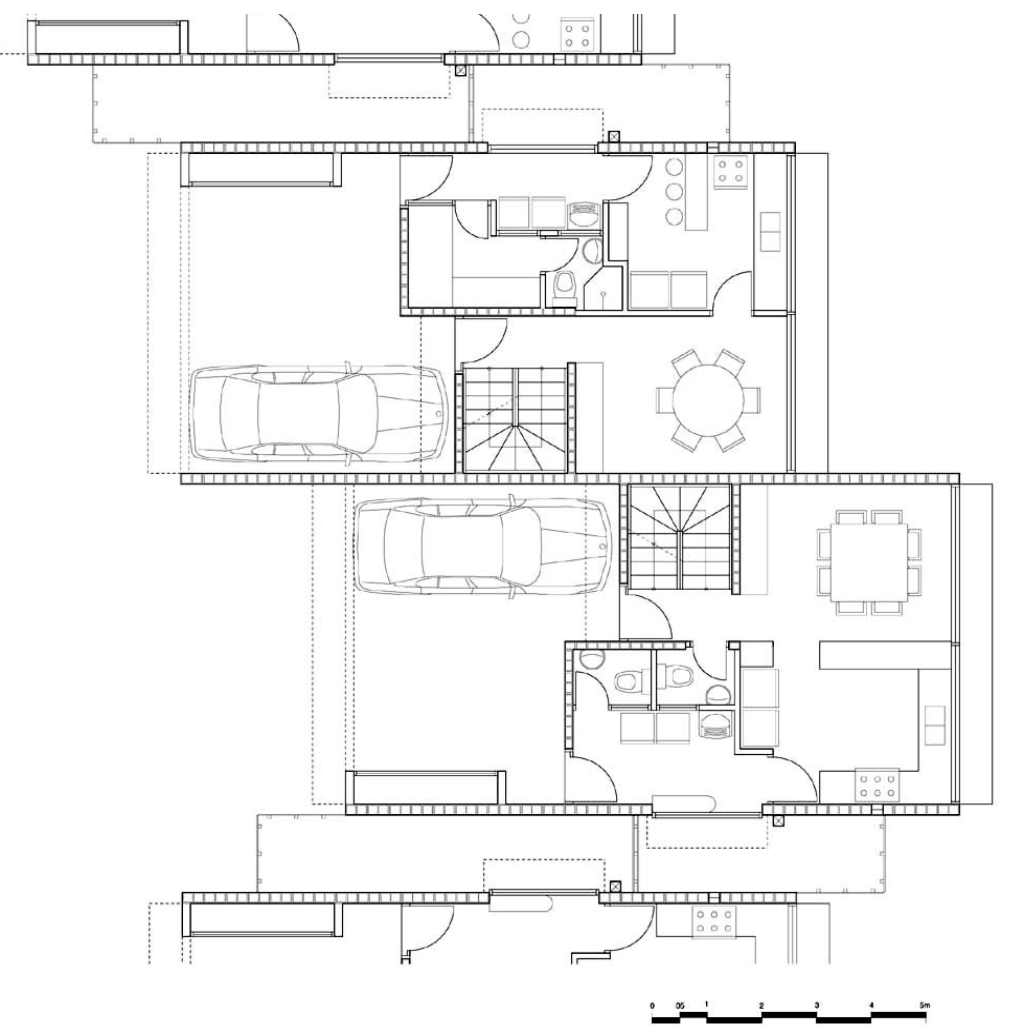

Fig. 9.8: Planta pavimento térreo. Tipologias 1 e 2. (fonte: arquivo pessoal Marcos Acayaba) 
Capítulo 9

Vila Butantã

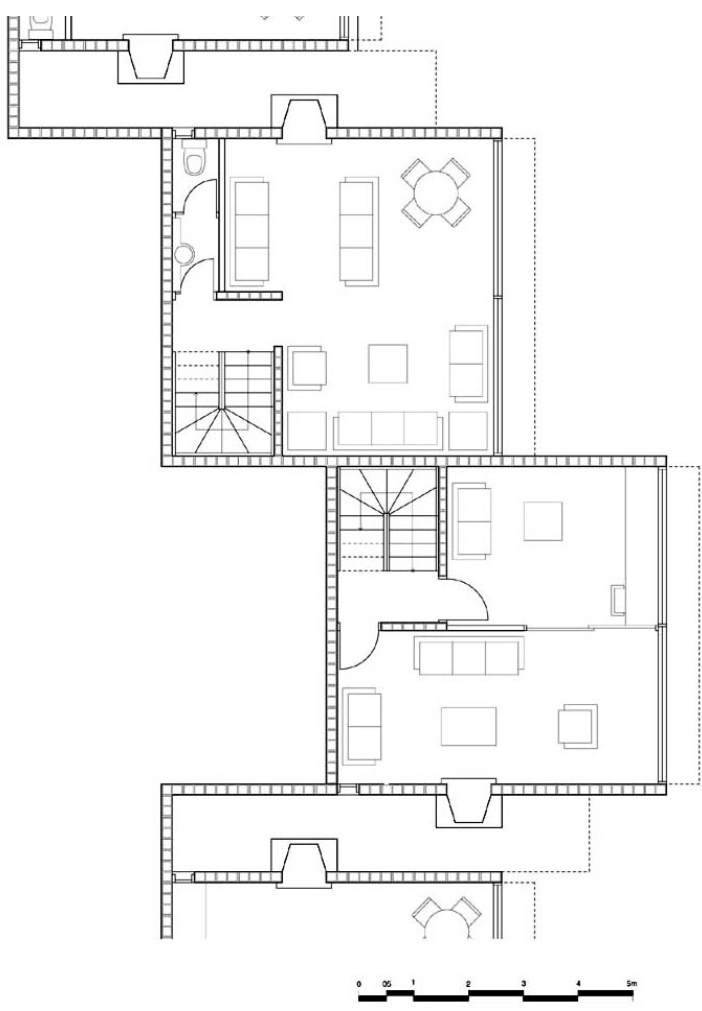

Fig. 9.9: Planta pavimento inferior. Tipologias 1 e 2. (fonte: arquivo pessoal Marcos Acayaba)

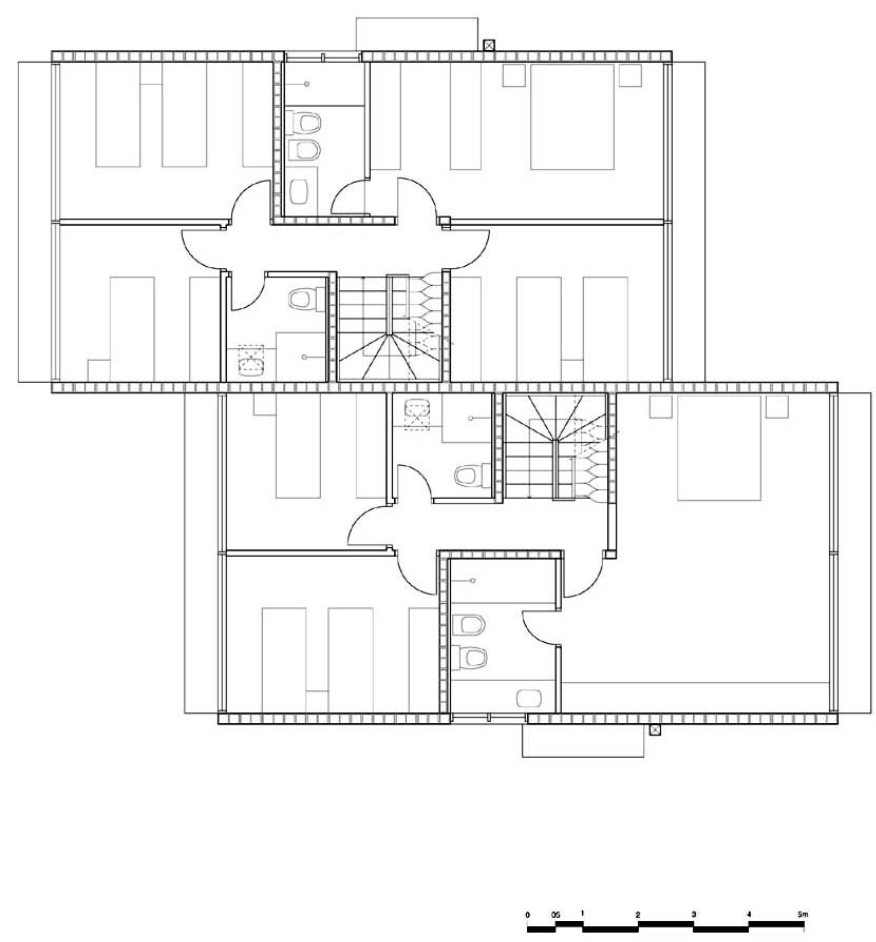

Fig. 9.10: Planta pavimento superior. Tipologias 1 e 2 . (fonte: arquivo pessoal Marcos Acayaba) 
Capítulo 9

Vila Butantã
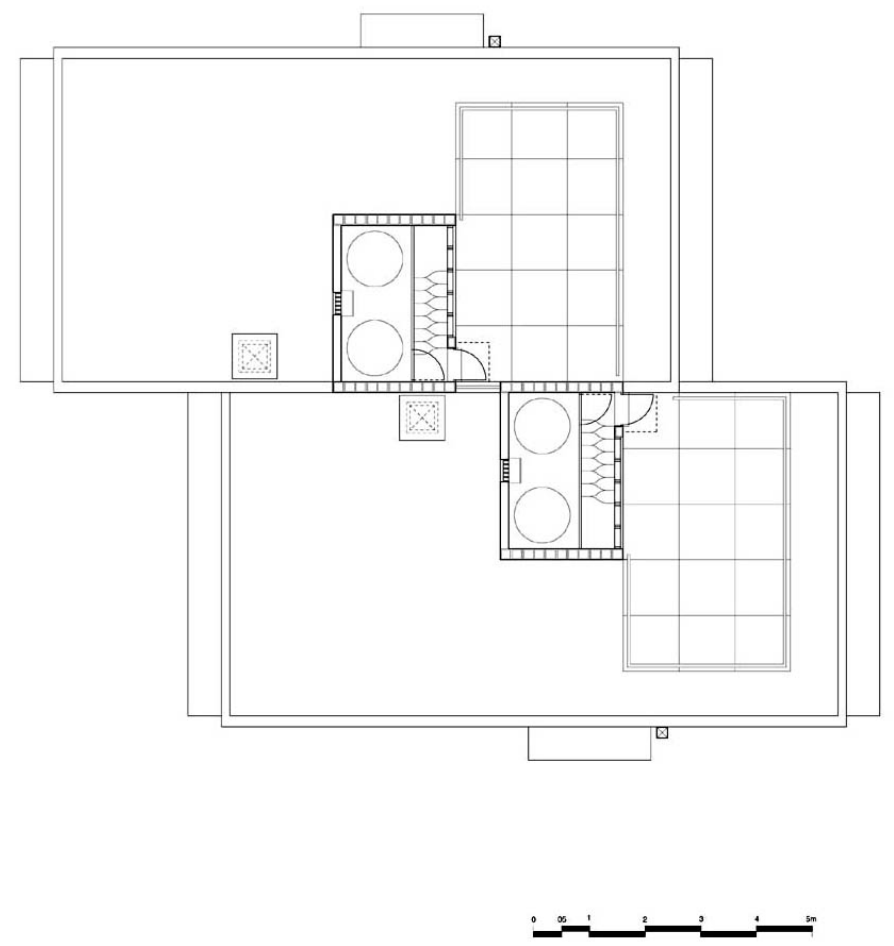

Fig. 9.11: Planta cobertura. Tipologias 1, 2, 3 e 4. (fonte: arquivo pessoal Marcos Acayaba)

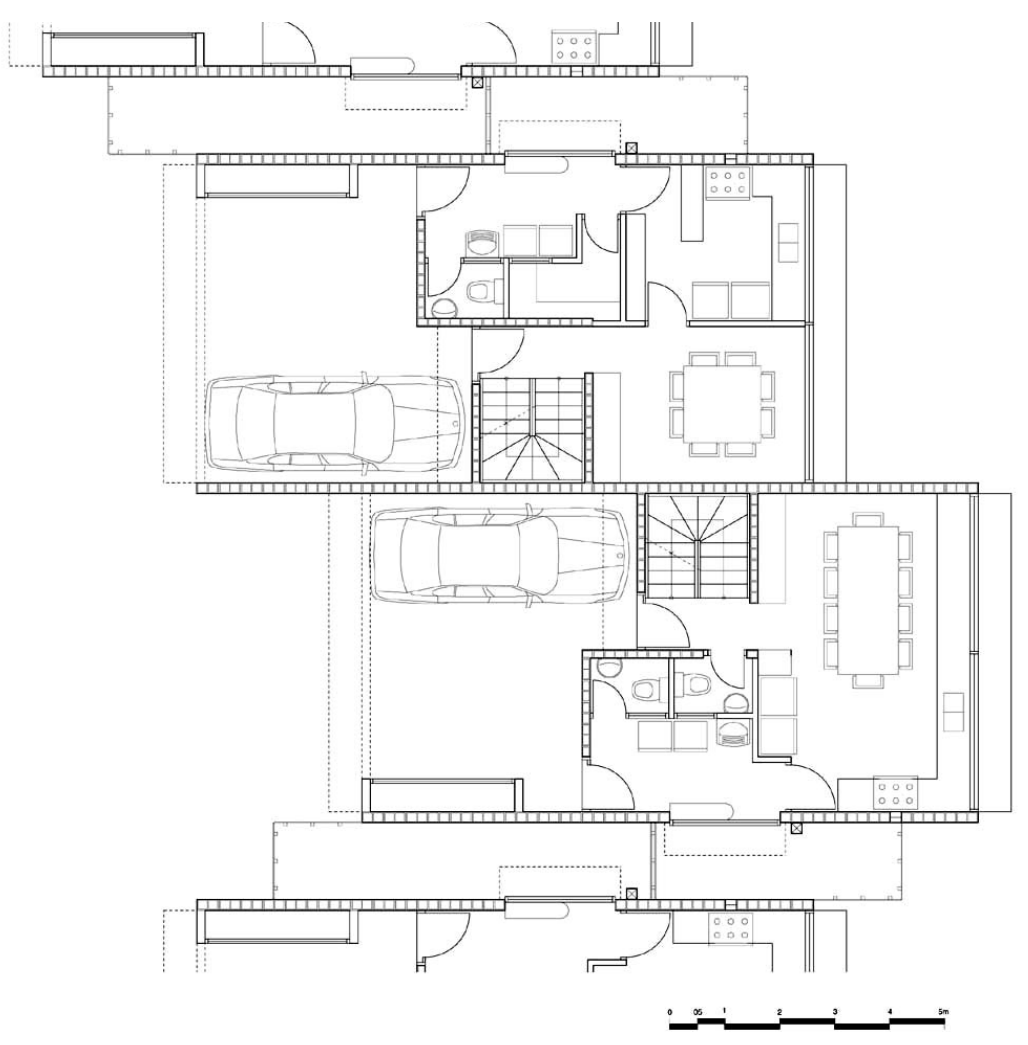

Fig. 9.12: Planta pavimento térreo. Tipologias 3 e 4. (fonte: arquivo pessoal Marcos Acayaba) 
Capítulo 9

Vila Butantã

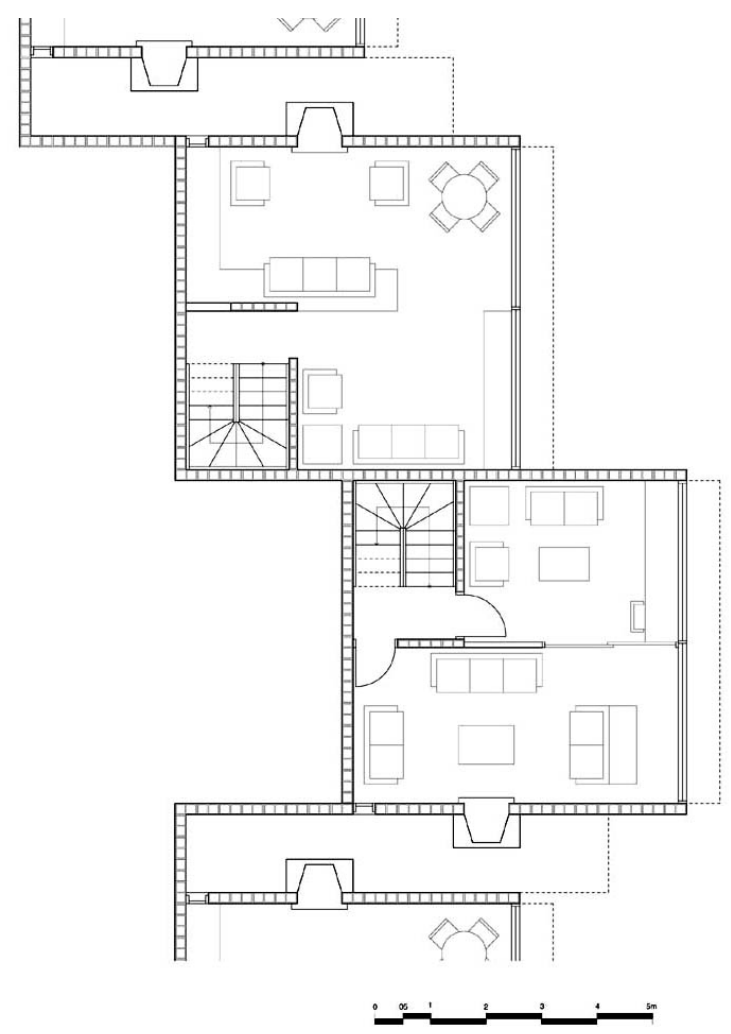

Fig. 9.13: Planta pavimento inferior. Tipologias 3 e 4. (fonte: arquivo pessoal Marcos Acayaba)

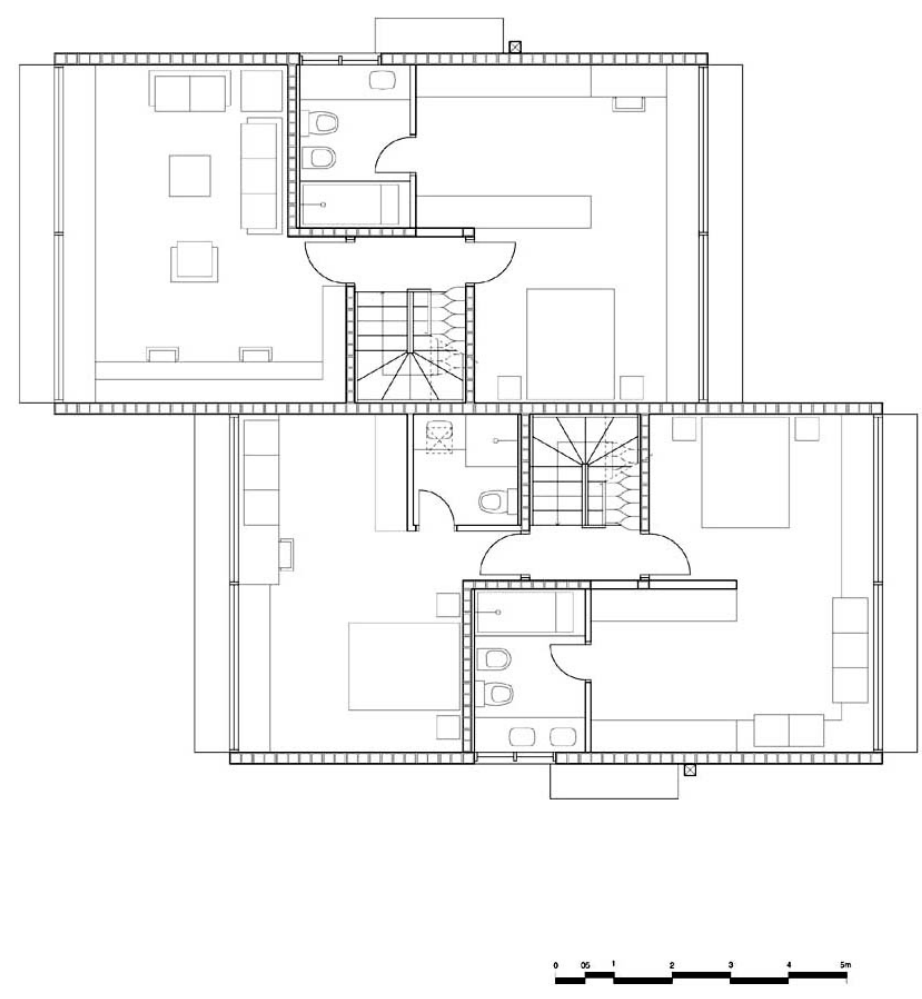

Fig. 9.14: Planta pavimento superior. Tipologias 3 e 4 . (fonte: arquivo pessoal Marcos Acayaba) 
Capítulo 9

Vila Butantã

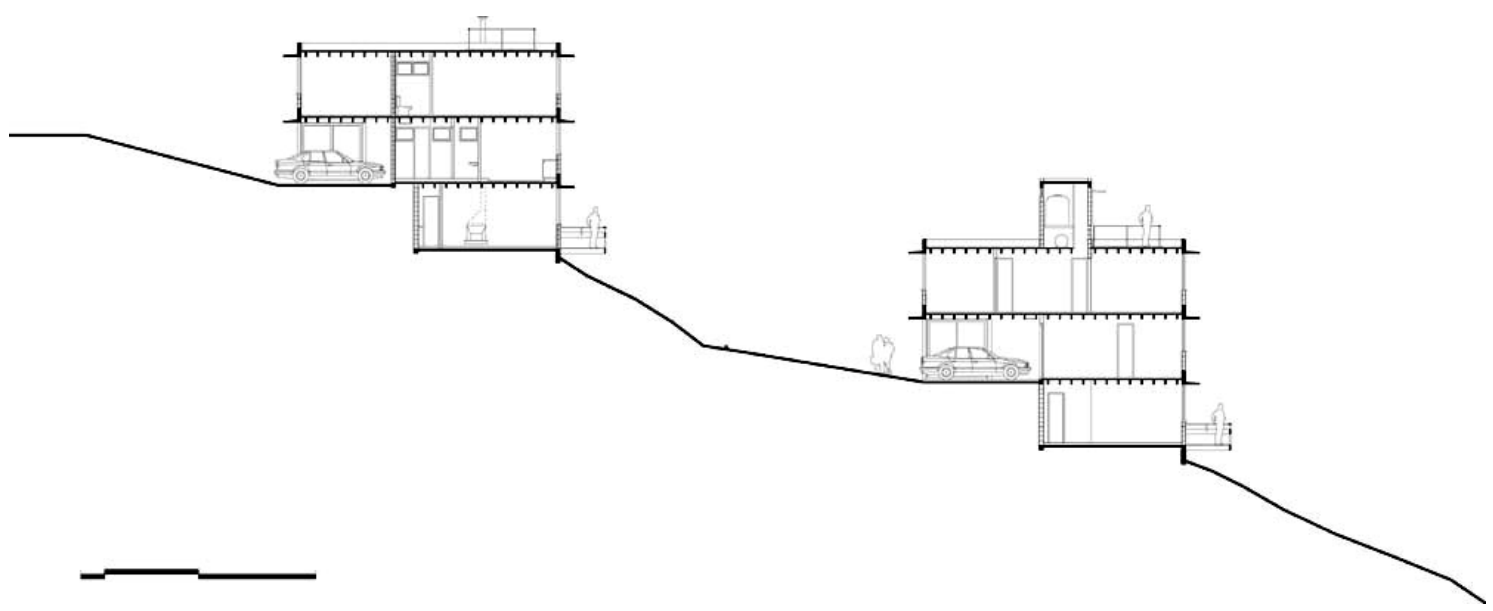

Fig. 9.15: Corte do terreno. (fonte: arquivo pessoal Marcos Acayaba)

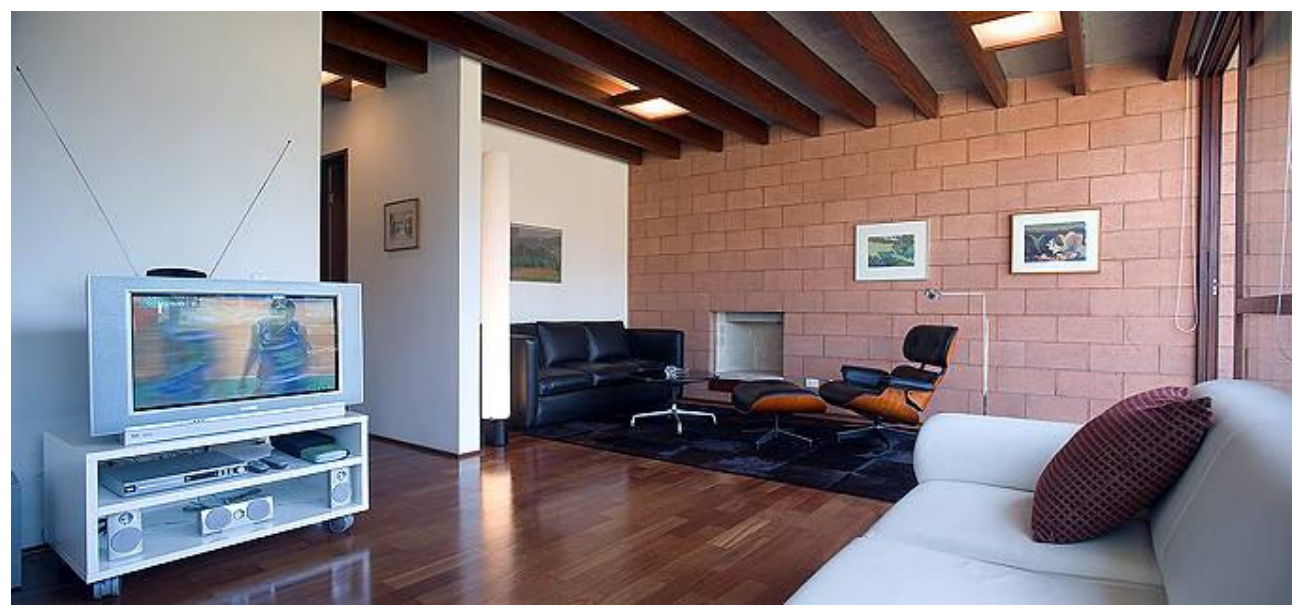

Fig. 9.16: Sala. (fonte: arquivo pessoal Marcos Acayaba)

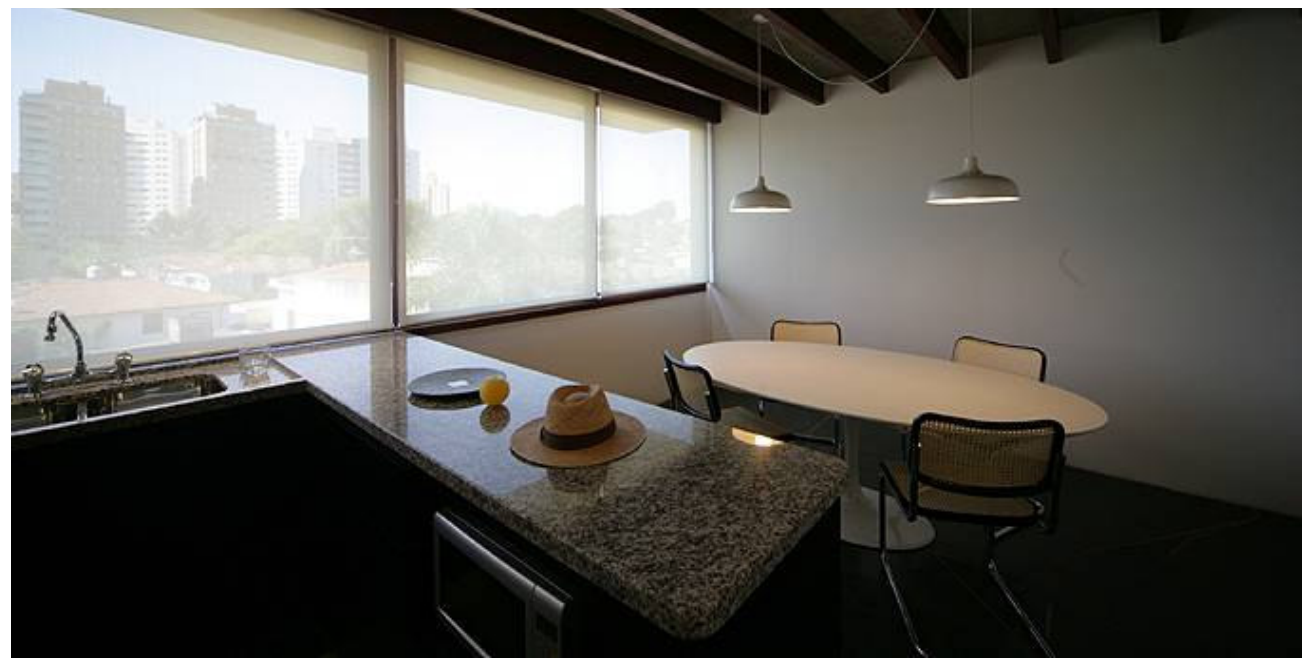

Fig. 9.17: Cozinha e sala de jantar. (fonte: arquivo pessoal Marcos Acayaba) 
Capítulo 9

Vila Butantã

\subsection{A solução construtiva}

\section{Laje nervurada em concreto e madeira}

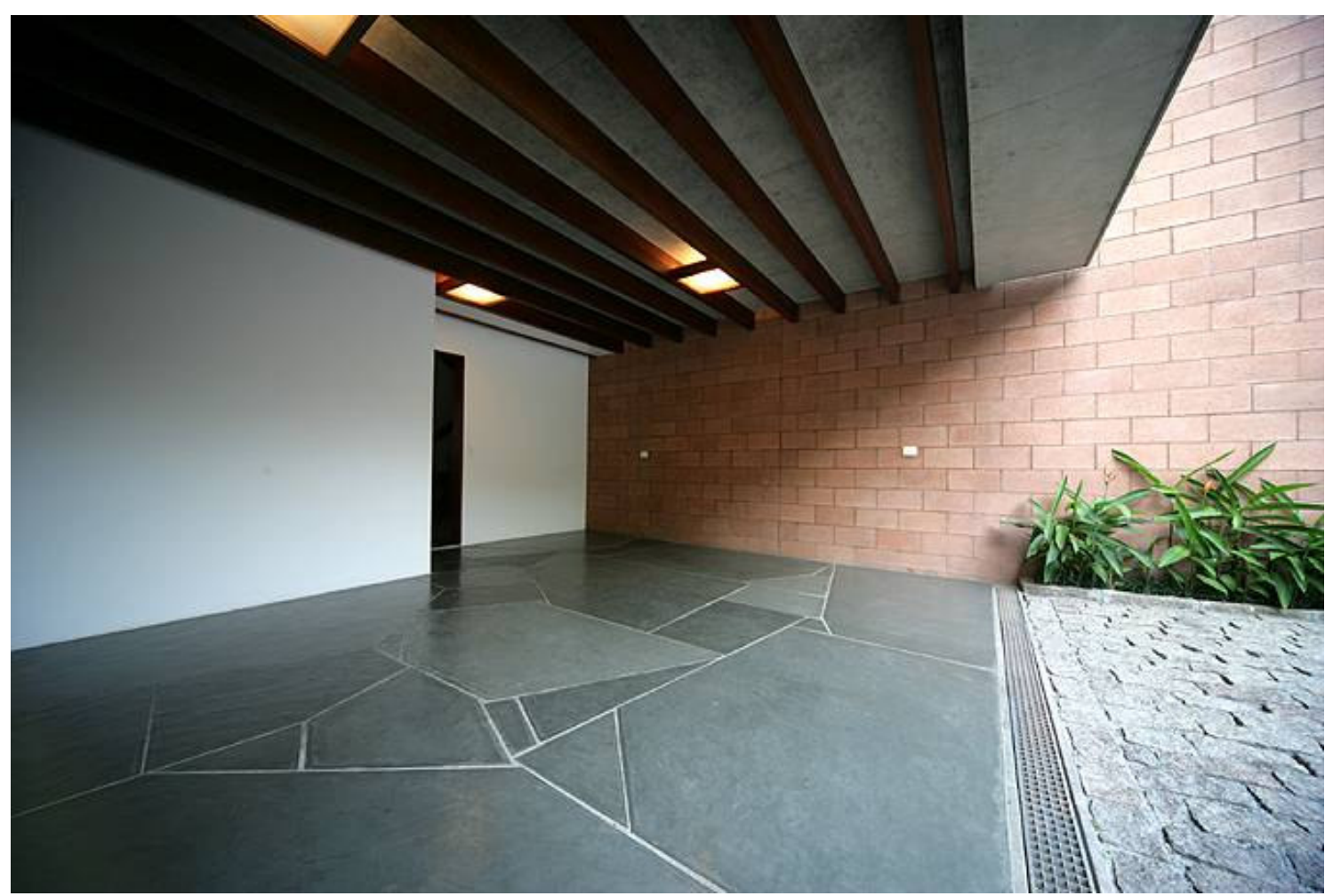

Fig. 9.18: Laje nervurada de madeira e concreto sobre garagem. (fonte: arquivo pessoal Marcos Acayaba)

O projeto das unidades da Vila Butantã previa duas empenas de blocos de concreto dentre as quais se sustentariam as lajes.

Fugindo da solução convencional de laje em concreto, Acayaba e Hélio Olga, decidiram propor uma solução até então nova no Brasil, um tipo de laje nervurada, de madeira e concreto, que foi patenteada depois de ensaios e estudos realizados pelo Instituto de Pesquisas Tecnológicas (IPT).

As lajes nervuradas, de acordo com a ASSOCIAÇÃO BRASILEIRA DE NORMAS TÉCNICAS (2003), NBR 61 18, são: "[...] lajes moldadas no local ou com nervuras pré-moldadas, cuja zona de tração para momentos positivos está localizada nas nervuras entre as quais pode ser colocado material inerte". 
Segundo Hélio Olga (SOUZA JR., 2007a), o desenvolvimento dessa solução contou com a colaboração do professor Pedro Almeida da Escola Politécnica da Universidade de São Paulo que, vendo a solução composta por vigas de madeira e laje de concreto adotada por Hélio e Marcos, sugeriu a utilização de lajes colaborantes sobre o vigamento aparente.

Souza Jr. (2007b) afirma que, antes da sugestão do professor Pedro, ele não utilizava a laje colaborante. Ela ficava "solta sobre os barrotes".

Segundo El Debs, costuma-se chamar de colaborante, a laje que se funde à viga trabalhando junto a ela as forças de compressão (informação verbal)².
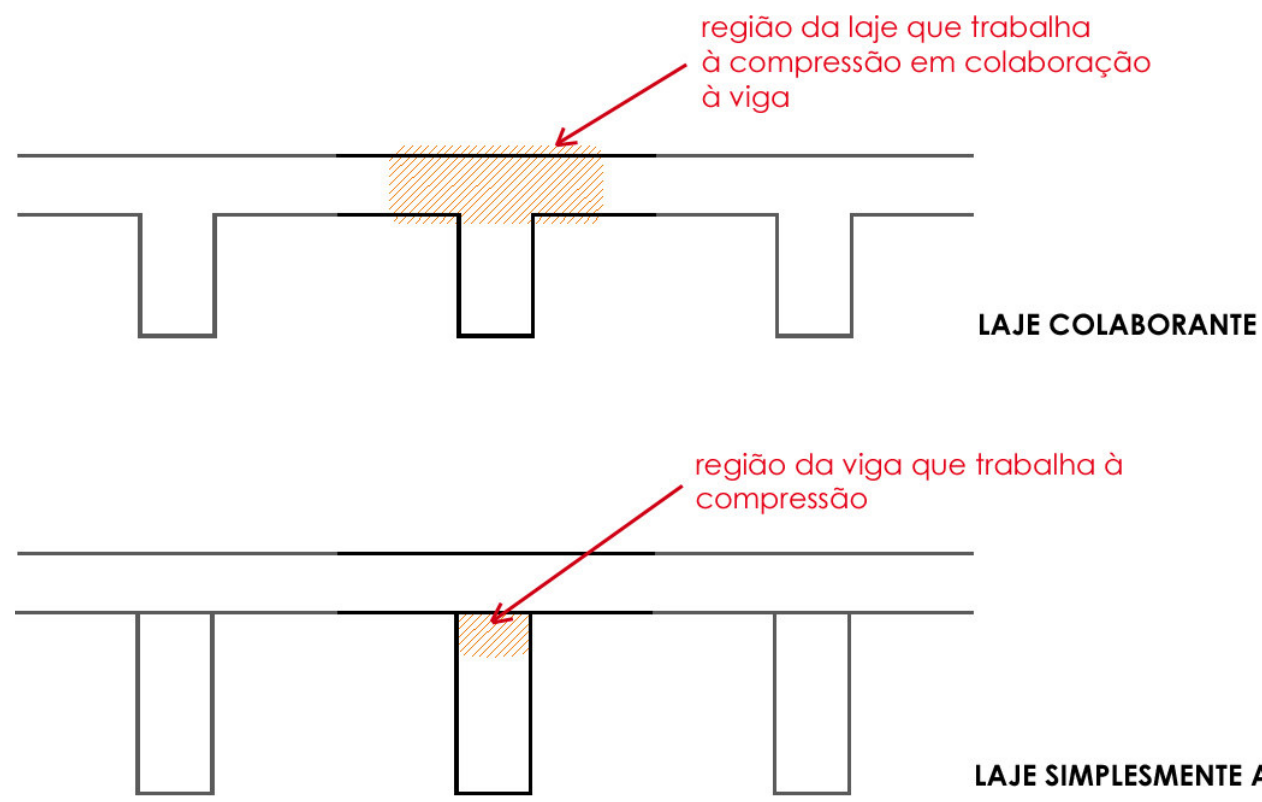

LAJE SIMPLESMENTE APOIADA

Fig. 9.19: Esquema ilustrativo de comparação entre laje colaborante e laje simplesmente apoiada. (fonte: autora)

Pode-se unir a viga de apoio e a laje através de conectores presos à viga que, na cura do concreto, solidarizam mecanicamente as duas partes. Essa solução pode ser utilizada em estruturas metálicas, em cujas vigas são chumbados conectores metálicos que se fundem ao concreto da laje.

No caso das casas da Vila Butantã, utilizou-se vigas de madeira e pregos fizeram a função de conectores.

2 Informação transmitida pelo Prof. Dr. Mounir Kalil El Debs em atendimento pessoal. 
Capítulo 9

Vila Butantã

As vigas são de jatobá, de $6,0 \mathrm{~cm} \times 20,0 \mathrm{~cm}$, colocadas a cada 50,0 cm, entre duas empenas de alvenaria armada de blocos pigmentados, com um vão total de $6,0 \mathrm{~m}$.

Entre elas são parafusadas fôrmas em chapas de aço galvanizado, sobre as quais é moldada a laje de concreto, de $4,0 \mathrm{~cm}$ de espessura, armada com uma tela de malha de $10,0 \mathrm{~cm} \times 10,0 \mathrm{~cm}$ e diâmetro de $4,2 \mathrm{~mm}$.

As fôrmas são fixadas diretamente nas vigas e não há necessidade de cimbramentos. Após a cura do concreto, as chapas galvanizadas são removidas e reutilizadas em outras unidades, evitando desperdício de material.

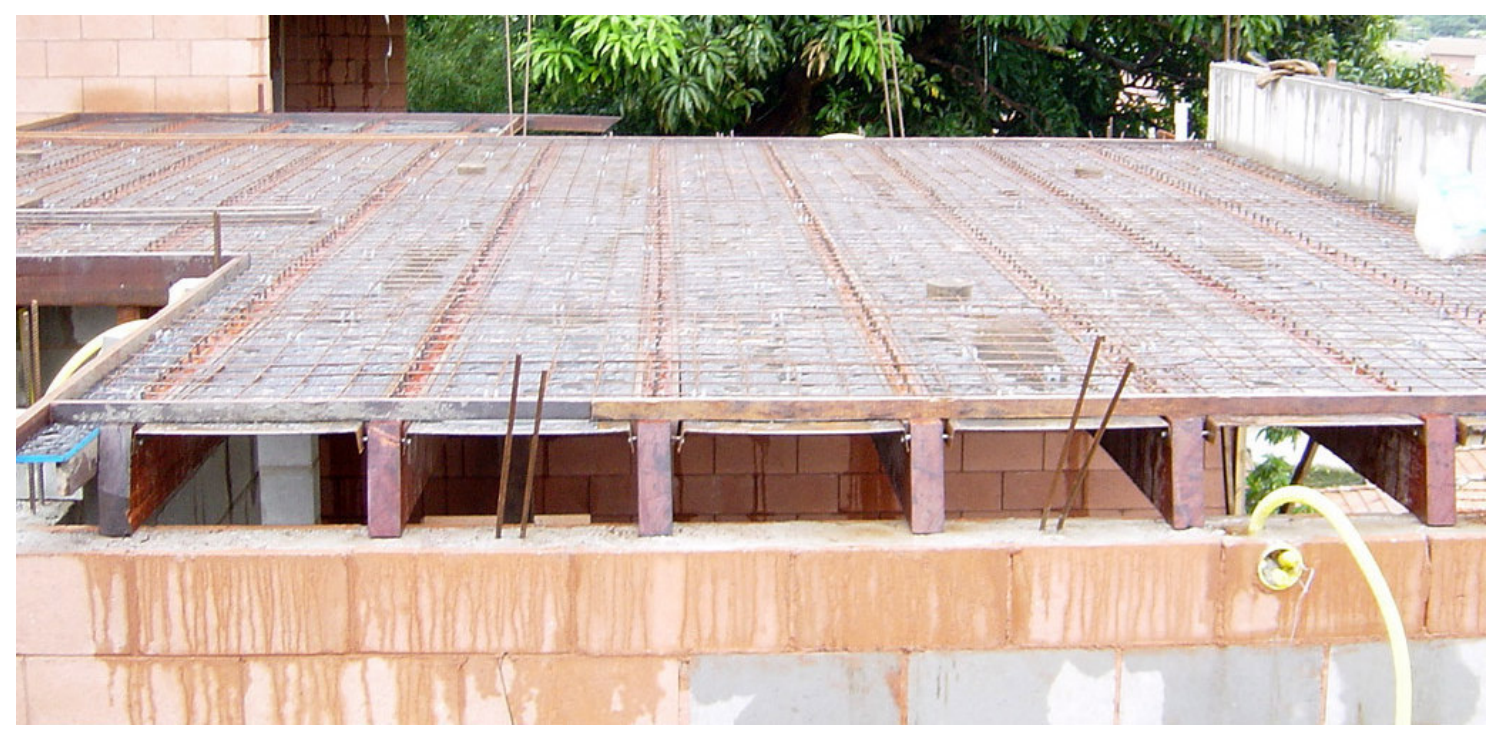

Fig. 9.20: Montagem da laje antes da concretagem. (fonte: arquivo pessoal Marcos Acayaba)

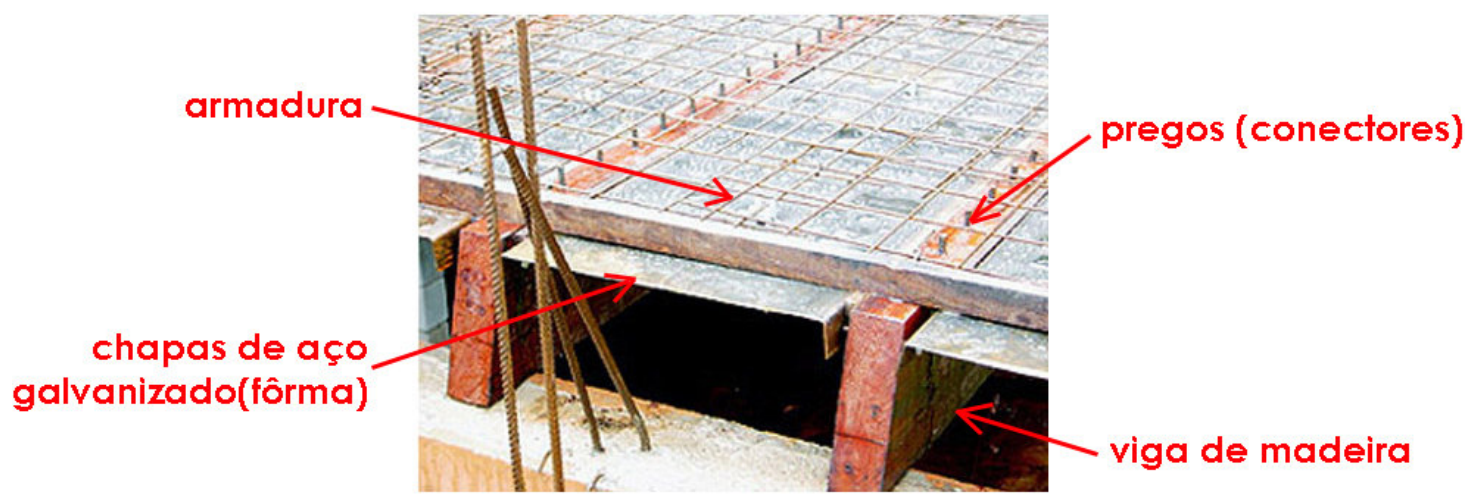

Fig. 9.21: Detalhe da construção da laje. (fonte: arquivo pessoal Marcos Acayaba - editada pela autora) 
Capítulo 9

Vila Butantã

Em projeto, os pregos que fazem a função de conectores presos às vigas tiveram seu espaçamento planejado de acordo com a cortante: mais próximos no apoio e afastados no meio do vão (SOUZA JR., 2007), como mostra a figura a seguir.

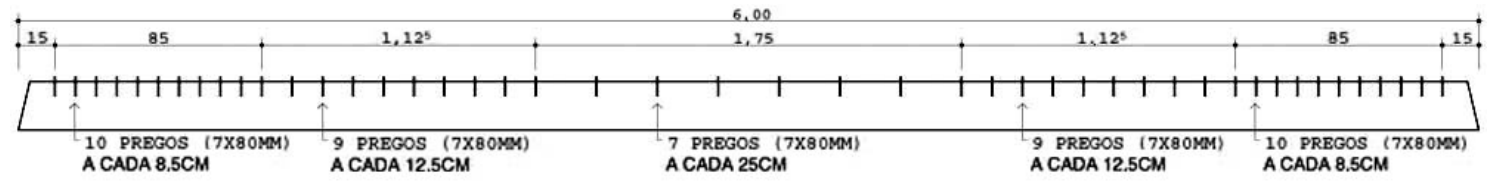

Fig. 9.22: Marcação dos pregos ao longo da viga. (fonte: arquivo pessoal Marcos Acayaba - editada pela autora)

No entanto, a partir da segunda série de casas, decidiu-se uniformizar o espaçamento em $8,5 \mathrm{~cm}$ de distância entre os pregos, segundo Souza Jr. (2007b), para "aumentar a rigidez do conjunto".

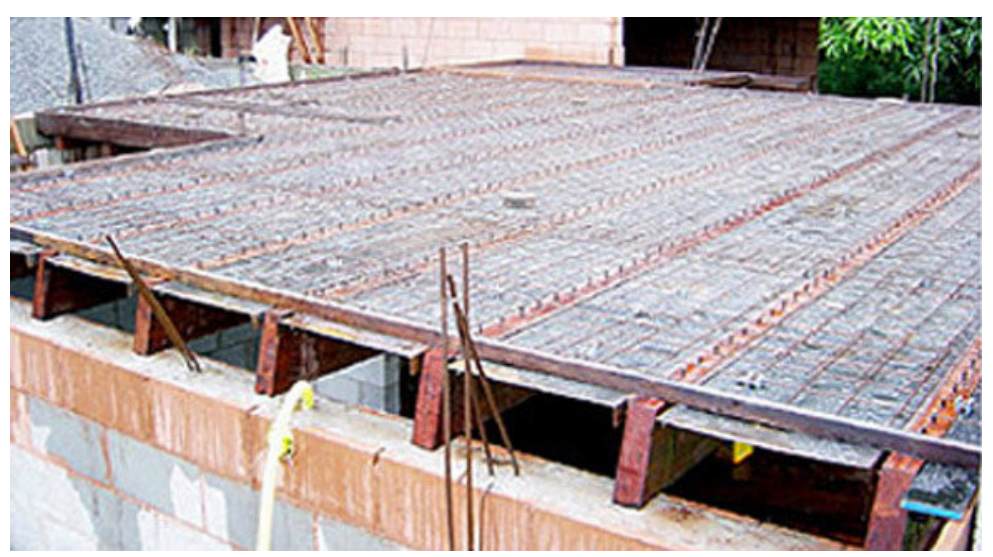

Fig. 9.23: 0 espaçamento uniformizado também facilita a execução. (fonte: arquivo pessoal Marcos Acayaba)

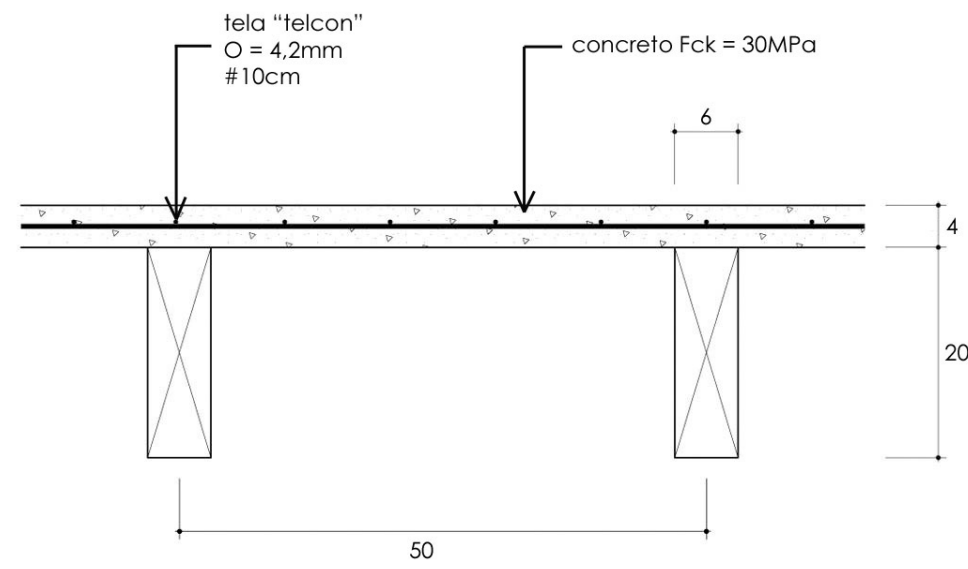

Fig. 9.24: Corte transversal da laje. (fonte: arquivo pessoal Marcos Acayaba - editada pela autora) 
Capítulo 9

Vila Butantã

Segundo Acayaba, as lajes de cobertura inicialmente não iriam funcionar como terraço. Foi durante a construção do primeiro bloco de casas (quatro unidades na parte superior do terreno) que ele, ao subir na laje, percebeu a bela vista que se tinha do bairro (informação verbal) ${ }^{3}$.

O arquiteto decidiu então, na fileira de casas seguinte, adotar uma solução baseada na utilizada em sua residência no Guarujá. Impermeabilizou a laje, lançou flocos de argila expandida por sobre ela e, em cima, apoiou placas de concreto que serviram como piso.

Com essa solução, as casas ganharam um espaço de lazer e contemplação e também tiveram seu desempenho térmico melhorado em relação à laje simples impermeabilizada.

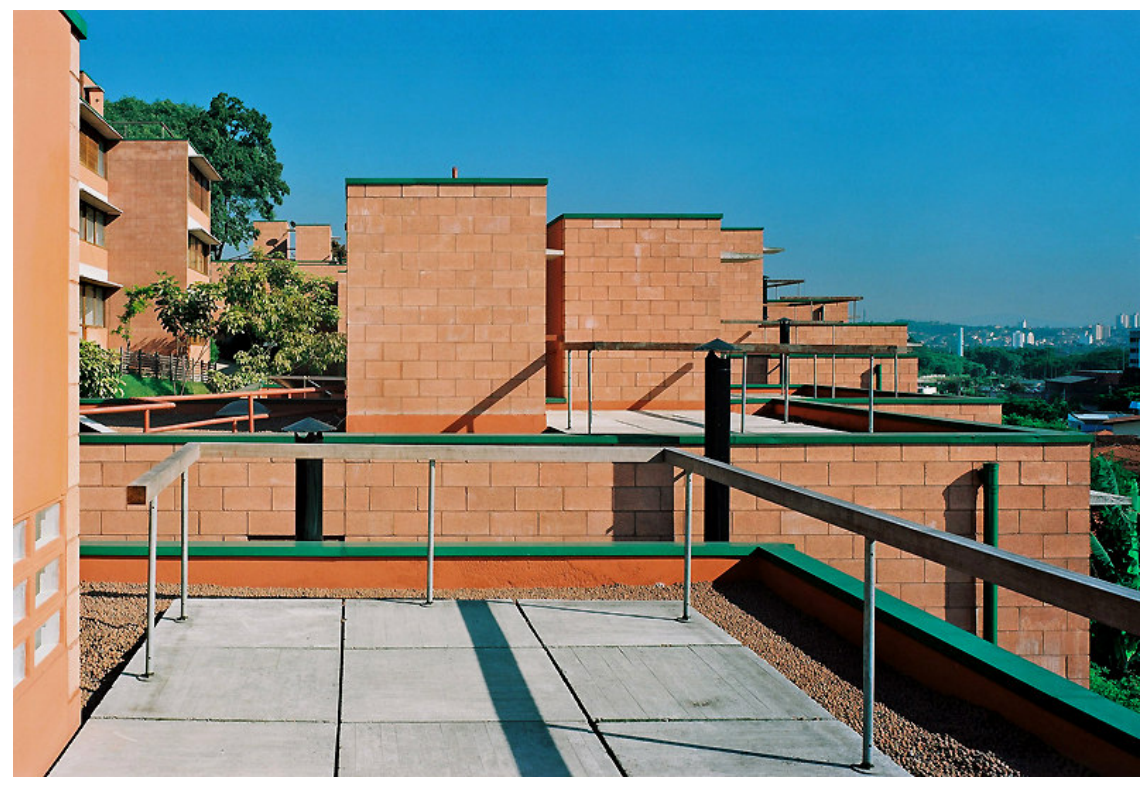

Fig. 9.25: Terraços.

(fonte: arquivo pessoal Marcos Acayaba)

A laje nervurada em concreto e madeira é uma solução interessante do ponto de vista construtivo e demanda um bom conhecimento técnico por parte do arquiteto, pois o vigamento em madeira exige a ordenação e a modulação espacial dos ambientes, adotando princípios de coordenação modular. É necessária a existência de uma boa interdisciplinaridade entre os projetos de arquitetura, estrutura, elétrica e hidráulica, seguindo os mesmos princípios de

\footnotetext{
3 Informação cedida por Acayaba em visita à Vila Butantã, em 2006.
} 
Capítulo 9

Vila Butantã

modulação. A posição das vigas, por exemplo, influencia em todos os projetos. A foto a seguir foi tirada da laje do lavabo. Demonstra que a posição e o dimensionamento desse ambiente foram pensados levando em consideração a posição das vigas, mantendo uma simetria e permitindo a locação das luminárias no eixo do ambiente.

As áreas molhadas são posicionadas de modo que as instalações hidráulicas corram por shafts horizontais visitáveis ${ }^{4}$, embutidos entre as vigas de madeira.

Entre os blocos foi previsto um shaft técnico vertical para descida de águas pluviais e esgoto e para abrigo do aquecedor e do gás de cozinha.

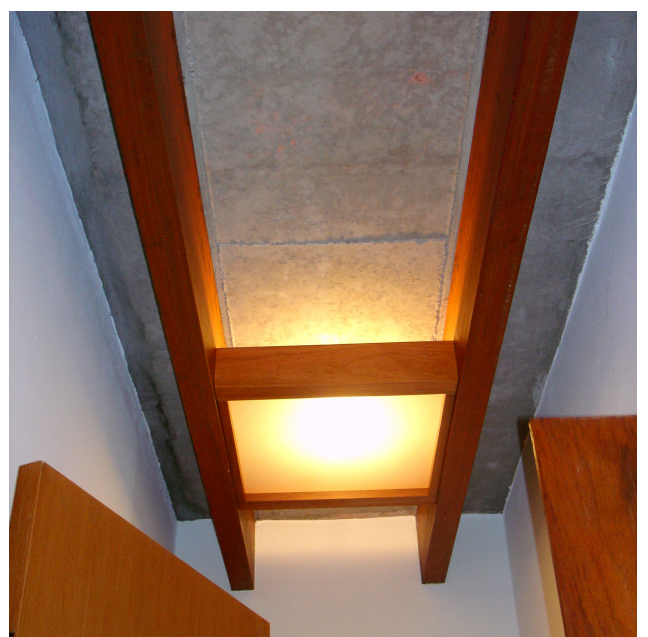

Fig. 9.26: Lavabo. Simetria na posição das vigas e luminária demonstra o diálogo entre os projetos de arquitetura, estrutura e elétrica. (fonte: autora)
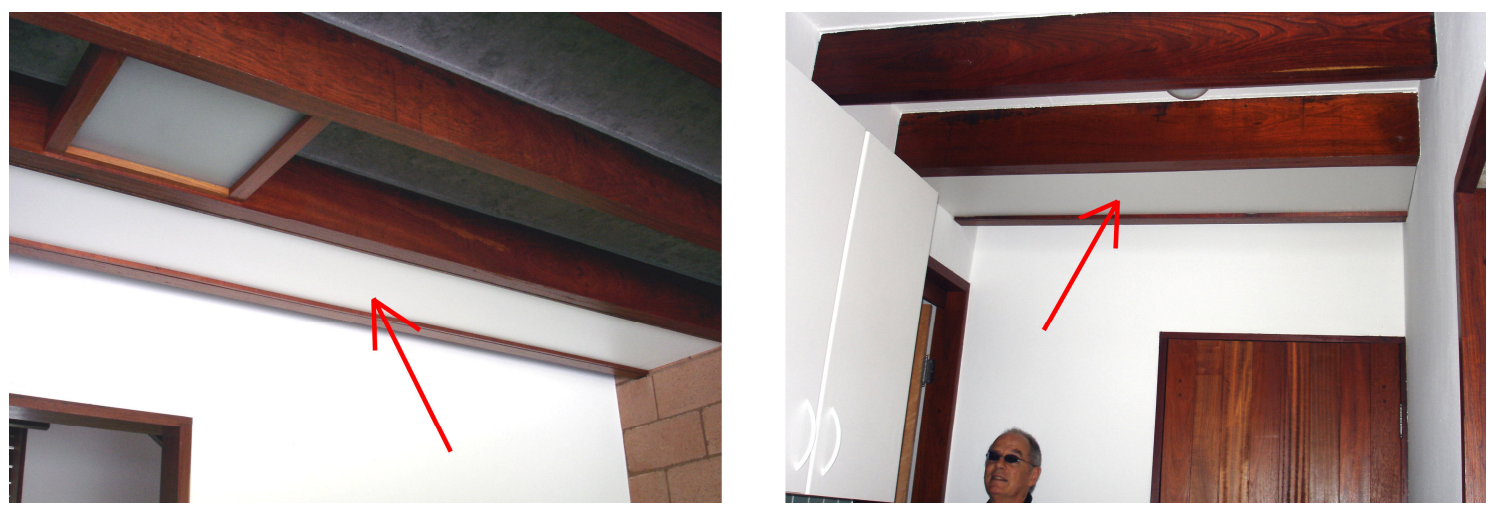

Fig. 9.27: Shafts horizontais. À esquerda, na garagem, e à direita, na área de serviço. (fonte: autora)

\footnotetext{
${ }^{4}$ A idéia de shaft costuma estar relacionada a dutos verticais que transpassam os pavimentos de uma construção com o intuito de concentrar as prumadas de instalações hidráulicas ou elétricas, facilitando a execução e a manutenção do edifício. No caso da Vila Butantã, além do espaço lateral entre as casas que, apesar de aberto, chamei de shaft vertical, por concentrar prumadas hidráulicas, também se utiliza o vão conformado entre as vigas de madeira para a passagem de tubulações de esgoto, por isso o termo shaft horizontal. O termo visitável se dá pela possibilidade de remoção da placa de fechamento.
} 
Capítulo 9

Vila Butantã
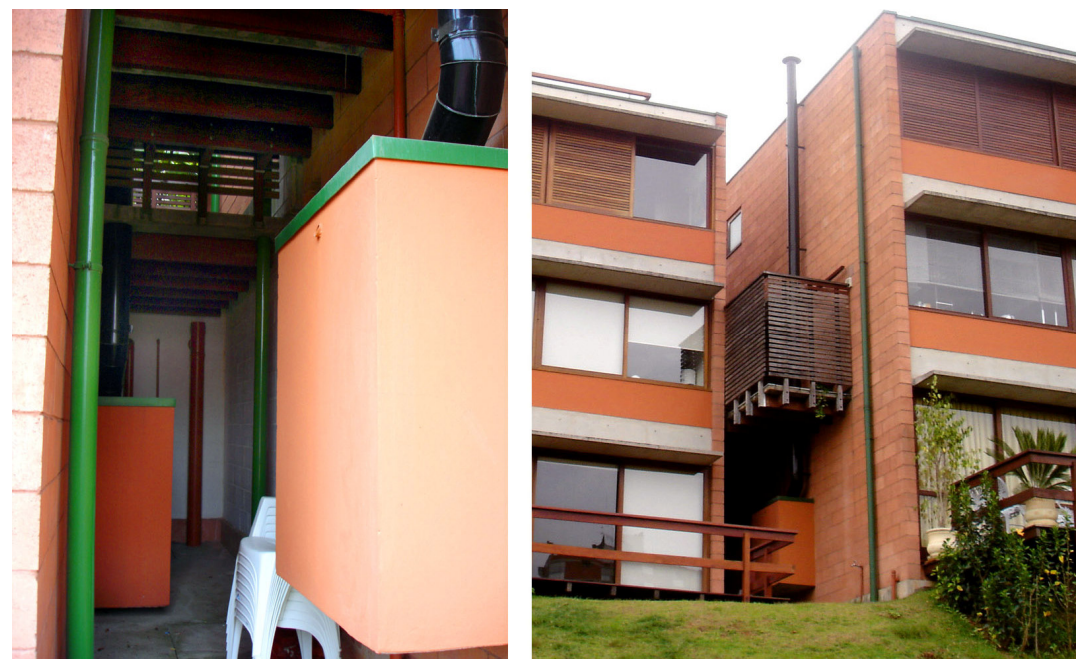

Fig. 9.28: Espaço entre os blocos funciona como shaft, concentrando instalações de água e gás. (fonte: autora)

Outro diferencial desse projeto em relação aos demais empreendimentos do setor foi a solução adotada para evitar conter os barrancos resultantes dos cortes no terreno e para evitar infiltrações rente aos muros de divisa. Ao invés de se utilizar muros de arrimo convencionais, que envolvem altos custos, foram utilizados arrimos de solo-cimento.

Segundo Ferreira (2007), o solo-cimento é "[...] um material obtido através da mistura homogênea de solo, cimento e água [...] que, após compactação e cura úmida, resulta num produto com características de durabilidade e resistências mecânicas".

O arrimo em solo-cimento é um material barato, de fácil uso e manutenção e boa durabilidade. Além disso, permite ser coberto pela vegetação, adquirindo um caráter paisagístico.
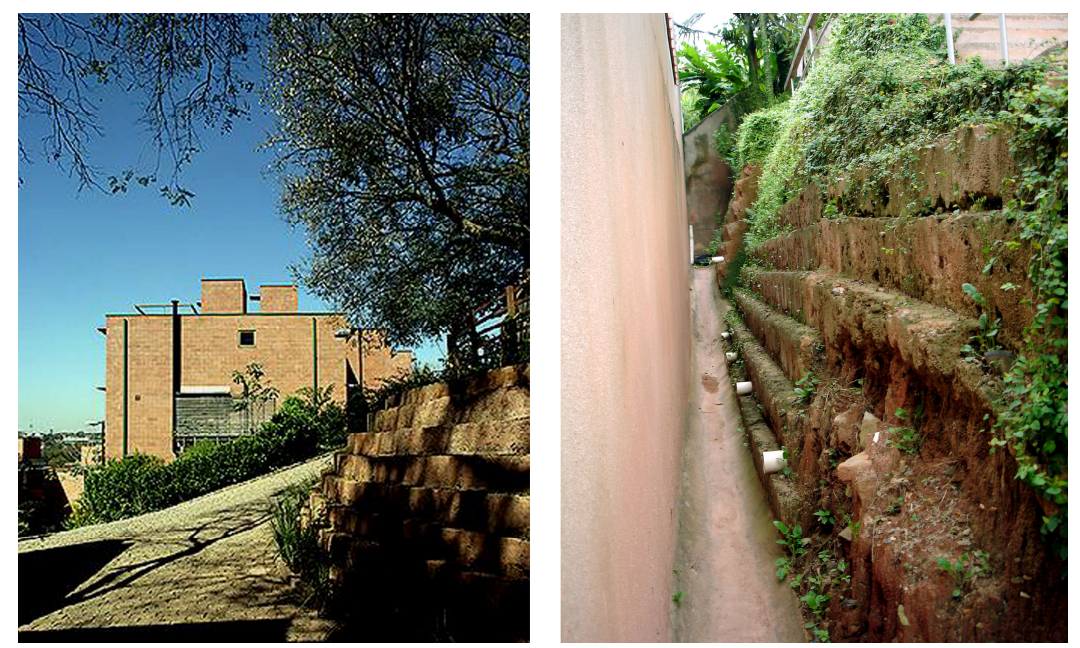

Fig. 9.29: Arrimo de solo cimento. (fonte: à esquerda, arquivo pessoal Marcos Acayaba; à direita, autora) 


\subsection{Considerações sobre o projeto}

Apesar de, como nas casas no Guarujá, o terreno possuir uma forte inclinação, o sistema construtivo adotado nesse caso foi outro.

Em virtude do tipo de empreendimento, da localização (em meio à metrópole) e do programa (conjunto de casas para fins imobiliários), adotouse na construção das unidades habitacionais, a alvenaria armada em blocos de concreto. Nesse caso, o sistema se adapta bem às condições do local, devido ao desenho desalinhado dos blocos.

Algo que chama atenção nesse projeto é a coordenação entre os diversos sistemas que compõem a construção, mesmo que tenham sido utilizados materiais mais tradicionais. Diferente das casas em madeira, em que os projetos de instalações se conformam praticamente em função da estrutura, nesse projeto, a coordenação modular articula as especialidades de maneira mais homogênea. A medida dos blocos interfere na modulação dos caixilhos e na estrutura. A estrutura interfere nas instalações elétricas e hidráulicas, que interferem na conformação dos espaços e assim por diante. Ao entrar no lavabo da casa, e ver que as vigas de madeira estavam posicionadas simetricamente e entre elas ficava a luminária, percebi que ali, havia um trabalho coordenado entre estrutura, arquitetura, elétrica e hidráulica. O que não acontece na maioria dos empreendimentos do setor, em que se costuma usar forro falso para esconder as instalações e revestimentos para esconder a estrutura.

Ao arquiteto nesse caso foi fundamental uma atenção constante às necessidades das outras áreas específicas, a interdisciplinaridade acaba se manifestando na plástica do edifício, trazendo beleza na articulação harmônica de suas funções. 
Capítulo 9

Vila Butantã

\subsection{Ficha técnica - Vila Butantã}

\begin{tabular}{|c|c|c|}
\hline \multicolumn{3}{|l|}{ Dados gerais } \\
\hline \multicolumn{2}{|l|}{ Local: } & Vila Pirajussara - São Paulo, SP \\
\hline \multicolumn{2}{|l|}{ Ano do Projeto: } & 1998 \\
\hline \multicolumn{2}{|l|}{ Período da Construção: } & 2004 \\
\hline \multicolumn{3}{|l|}{ Equipe de Projeto } \\
\hline \multicolumn{3}{|l|}{ Arq. Marcos Acayaba } \\
\hline \multicolumn{3}{|l|}{ Arq. Sueli Mizobe } \\
\hline \multicolumn{3}{|l|}{ Colaboradores } \\
\hline \multicolumn{2}{|l|}{ Construção: } & Ita Construtora \\
\hline \multicolumn{2}{|l|}{ Fotos: } & Nelson Kon \\
\hline \multicolumn{2}{|c|}{$\begin{array}{l}\text { Proj. Estr. Laje Nervurada } \\
\text { Concreto e Madeira: }\end{array}$} & $\begin{array}{l}\text { Helio Olga de Souza Jr., Prof. Dr. Pedro Afonso Oliveira Almeida, Prof. Dr. Péricles } \\
\text { Brasiliense Fusco }\end{array}$ \\
\hline \multicolumn{2}{|l|}{ Projeto de Instalações: } & Sandretec \\
\hline \multicolumn{2}{|c|}{ Projeto de Luminotécnica: } & Arq. Claudio Furtado \\
\hline \multicolumn{2}{|l|}{ Projeto Paisagístico: } & Arq. Benedito Abbud \\
\hline \multicolumn{2}{|c|}{$\begin{array}{l}\text { Projeto Estrutural Alvenaria } \\
\text { Armada/ Fundações: }\end{array}$} & Eng $^{\circ}$. Luis F. Meirelles Carvalho \\
\hline \multicolumn{3}{|l|}{ Programa } \\
\hline \multicolumn{3}{|c|}{16 unidades unifamiliares (população estimada em 64 pessoas, densidade líquida 144hab/ha) } \\
\hline \multicolumn{3}{|c|}{ Casas geminadas duas a duas ( 2 renques de 4 e 12 casas) } \\
\hline \multicolumn{3}{|c|}{ Programa de lazer: gramado multiuso (futebol, etc.), salão, bar, depósito, vestiários e piscina } \\
\hline \multicolumn{3}{|c|}{ Garagens individuais: 2 vagas cobertas e 1 vaga descoberta por casa } \\
\hline \multicolumn{3}{|c|}{ Portaria Geral / Sala para Medidores } \\
\hline \multicolumn{3}{|l|}{ Materiais } \\
\hline Alvenaria: & \multicolumn{2}{|c|}{ Bloco de concreto } \\
\hline Caixilhos: & \multicolumn{2}{|c|}{ Madeira } \\
\hline Acabamentos: & \multicolumn{2}{|c|}{ Pintura acrílica } \\
\hline Pisos: & \multicolumn{2}{|r|}{ Interno: Madeira / Externo: Ardósia, concreto desempenado, paralelepípedo } \\
\hline \multicolumn{3}{|l|}{ Áreas } \\
\hline Área do Terreno: & \multicolumn{2}{|c|}{$4439,0 \mathrm{~m}^{2}$} \\
\hline Área Ocupada: & \multicolumn{2}{|c|}{$1140,0 \mathrm{~m}^{2}$} \\
\hline Taxa de Ocupação: & \multicolumn{2}{|c|}{$25,7 \%$} \\
\hline Área Útil Casa Tipo: & \multicolumn{2}{|c|}{$173,69 \mathrm{~m}^{2}$} \\
\hline Área Privativa: & \multicolumn{2}{|c|}{$2244,0 \mathrm{~m}^{2}$ (28\% da área total) } \\
\hline
\end{tabular}


O conflito entre técnica e arte prevalece ainda hoje [...] A consciência humana, com seu lado sensível e seu lado racional, não tem sido convenientemente interpretada como um inteiro, mas como a soma de duas metades (ARTIGAS, 2004, p. 117).

Artigas (2004) afirma que somente quando "[...] a arte for reconhecida como linguagem dos desígnios do homem", o conflito entre arte e técnica cessará. Marcos Acayaba, como discípulo, tenta quebrar esse paradigma, utilizando seu domínio técnico como instrumento de uma constante investigação plástica e espacial.

Em sua atividade, ficam claras as marcas de sua formação, notoriamente mais como conceito do que como linguagem, na medida em que suas posturas projetuais representam antes um método do que um modelo. Por isso, cada um dos projetos apresenta uma linguagem diferenciada, muito particular.

A produção mais recente de Acayaba, de maneira geral, obedece a princípios em comum, como a adequação do sistema construtivo ao programa e ao meio físico em que se insere, a constante atenção às peculiaridades dos diversos materiais utilizados, o cuidado com a obra e suas características de fluxos, mão de obra, montagem e manutenção e o detalhamento exaustivo do projeto. 
Nos primeiros projetos, as nuances dessa postura são menos notadas. Neles, a influência da produção arquitetônica do período acaba sendo preponderante. Tanto em termos formais, quanto em termos construtivos. No projeto da residência Milan, realizado bem no início de sua carreira, Acayaba adota uma linguagem muito utilizada na época, a da cobertura em abóbada, fazendo uso da tecnologia do concreto armado, também amplamente difundida no contexto nacional. Alguns anos depois, realizou-se o projeto da casa-sede da Fazenda Pindorama, que também adotava uma linguagem de abóbadas como cobertura, mas já utilizava técnicas construtivas mais "adequadas a um projeto de residência"l, num sistema de moldagem com cambotas, muito próximo ao que Sérgio Ferro e outros arquitetos desenvolviam, diferenciando-se pelo uso do bloco de concreto ao invés do tijolo de barro. Dez anos depois, houve a experiência do pavilhão de lazer da mesma fazenda, um projeto que, para se manter a linguagem plástica idealizada pelo arquiteto, sem prejudicar o conforto térmico do edifício, criou-se uma nova solução construtiva, a parede de tijolos e concreto.

Depois de cerca de vinte anos em atividade, surgem as residências em madeira, projetos que talvez, junto com a Vila Butantã, melhor exemplifiquem o que essa pesquisa pretende demonstrar. Com o desenvolver da prática profissional, o conhecimento técnico e tecnológico adquirido possibilitou ao arquiteto desenvolver, em parceria com o engenheiro Hélio Olga, com quem mantém uma fluida interdisciplinaridade, uma nova solução construtiva que, por si, gerava ao também uma linguagem inovadora. Nesses projetos, toda a investigação formal manteve-se constantemente atrelada ao desenvolvimento do partido estrutural, as soluções técnicas correspondem às intenções formais, numa arquitetura da "[...] estética da lógica, onde as soluções devem escolher os materiais mais convenientes, as técnicas mais justas, evidenciando a racionalidade e o ajuste programático também como expressão plástica, intenção plástica" (SEGAWA, 1996, p. 36).

\footnotetext{
1 Acayaba (2004), faz uma auto-crítica quando fala sobre a escolha do sistema construtivo adotado na residência Milan: "Para fazer a concretagem em um só dia, foi usada uma técnica, naquele momento nova $\mathrm{n}$ Brasil, a do bombeamento e lançamento de concreto em altura (uma sofisticação que eu não sei se caberia na obra de uma residência)" .
} 
A partir desses estudos, ressalta-se a importância, não só do conhecimento técnico por si, mas do seu uso e desenvolvimento atrelado às questões da arquitetura enquanto arte e espaço num trabalho conjunto, em que as soluções construtivas se fundem às intenções formais, soando em uníssono. Traz a reflexão sobre a postura dos arquitetos, buscando demonstrar que o domínio técnico (e tecnológico) pode não ser a única resposta para as grandes pendências da arquitetura, mas, sem dúvida, constitui-se numa extraordinária ferramenta na árdua tarefa de se construir e aproximar 0 pensar e o fazer arquitetônico.

Possibilidades de trabalhos futuros:

Ao fim da pesquisa, é possível pensar que ela até poderia ter um outro nome, algo como: O domínio técnico como um instrumento de criação arquitetônica. Porém, fica a idéia para as próximas investigações, as quais poderiam reunir estudos de obras variadas, de diversos arquitetos contemporâneos, que, assim como Acayaba, utilizam-se do domínio técnico e tecnológico para conceber "arquiteturas da lógica e da beleza, onde nada sobra e nada falta"2.

\footnotetext{
2 Parte do título de um artigo de Hugo Segawa para a revista ProjetoDesign: "As vertentes da invenção arquitetônica: arquiteturas da lógica e da beleza, onde nada sobra e nada falta", da edição número 198, de julho de 1996, em que se apresenta uma série de projetos de Marcos Acayaba.
} 


\section{REFERÊNCIAS}

ACAYABA, Marcos. Pavilhão Pindorama. Projeto. n. 75, 1985, p. 43-46. Por . Residências em São Paulo (1947-1975). São Paulo: Projeto, 1986. 06-13. . Entrevista. Caramelo, Caramelo FAU USP, São Paulo, n.3, out. 1991. p.

Conferência. Bienal Internacional do Chile, 1997. Discurso. Texto fornecido pelo próprio autor. Ohtake, 2003.

. Depoimento. João Batista Vilanova Artigas. São Paulo: Instituto Tomie - Projeto, pesquisa, construção. São Paulo, 2004. Tese (Doutorado). Universidade de São Paulo. FAU - Faculdade de Arquitetura e Urbanismo. 3v.

- Marcos Acayaba: entrevista. Entrevistador: Tatiana Midori Nakanishi. Guarujá. 1 CD-ROM. 25 ago. 2006.

- Marcos Acayaba: entrevista. Entrevistador: Tatiana Midori Nakanishi. São Paulo. 1 CD-ROM. 22 fev. 2007.

A máquina de desenhar e o recurso de criação. Projeto, set. 1993. p. 60-62.

ARANTES, Pedro Fiori (org.). Sérgio Ferro. Arquitetura e trabalho livre. São Paulo: COSAC NAIFY, 2006.

ARTIGAS, J. B. Vilanova. A função social do arquiteto. São Paulo: Ed. Nobel, 1989.

. Caminhos da arquitetura. São Paulo: Cosac Naify, 2004. 234p.

ASSOCIAÇÃO BRASILEIRA DE NORMAS TÉCNICAS - ABNT. NBR 15220. Desempenho Térmico de Edificações. Rio de Janeiro, ABNT, set. 2003.

ASSOCIAÇÃO BRASILEIRA DE NORMAS TÉCNICAS - ABNT. NBR 6118. Projeto de Estruturas de Concreto - Procedimento. Rio de Janeiro, ABNT, mar. 2004.

BARDI, Pietro Maria. Engenharia e arquitetura na construção. São Paulo: Banco Sudameris Brasil S. A., 1985.

BASTOS, Maria Alice Junqueira. Pós-Brasília, rumos da arquitetura brasileira. São Paulo: Fapesp/ Perspectiva, 2003.

BENÉVOLO, Leonardo. História da arquitetura moderna. Trad. Ana M. Goldberger. 2. ed. São Paulo: Perspectiva, 1989.

BENTES, Ruy Franco. Dúvidas [mensagem pessoal]. Mensagem recebida por <tati_nakanishi@yahoo.com> em abr. 2007. 
Referências

BIROU, Alain. Dicionário das Ciências Sociais. Lisboa, D. Quixote, 1966.

BOTELHO, Manuel Henrique Campos. Concreto armado eu te amo. São Paulo: Edgard Blusher, 1983. 489p.

BRUAND, Yves. Arquitetura contemporânea no Brasil. Trad. Ana M. Goldberger. 3 ed. São Paulo: Perspectiva, 1999.

BUZZAR, Miguel A. João Batista Vilanova Artigas: elementos para a compreensão de um caminho da arquitetura brasileira, 1938-1967. 1996. Dissertação (Mestrado) - Faculdade de Arquitetura e Urbanismo, Universidade de São Paulo. 337 p.

Caminhos e Descaminhos da Arquitetura Brasileira. In: Projeto, n. 42, jul./ ago. 82, p. 54.

CARVALHO Jr., José Mário N. Projeto, construção e conhecimento operário (estudo de caso). São Paulo 1985. Dissertação (Mestrado). Universidade de São Paulo. Faculdade de Arquitetura e Urbanismo. 281 p.

. Prática de arquitetura e conhecimento técnico, 1994. Tese (Doutorado) - Faculdade de Arquitetura e Urbanismo, Universidade de São Paulo. 273 p.

CASA NO Jardim Vitória-Régia. Por ACAYABA, M. e OLGA, H. Projeto, n. 134, 1990, p.65-67.

CASA VALENTIM, Blumenau - SC. Paisagem como Projeto. $\underline{A U}$, n. 69, dez./ jan. 1997, p. 47-52. Por SABBAG, Haifa Y.

COMAS, Carlos Eduardo Dias. Arquiteturas Brasileira, Anos 80 - Um fio de

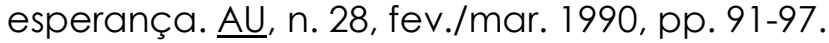

CONSTRUALIA, o portal de aço para a construção. Disponível em: <http://www.constructalia.com/br_BR/index.jsp>. Acesso em: 27 jun. 2007.

CORBUSIER, Le. Por uma arquitetura. Trad. Ubirajara Rebouças. 5. ed. São Paulo: Perspectiva, 1994. 205p.

DURAND, José Carlos G. A profissão do arquiteto: estudo sociológico. Imprenta Guanabara : Crea, 1974. Dissertação (Mestrado). Universidade de São Paulo. Faculdade de Filosofia, Letras e Ciências Humanas, nov. 1972. 113 p.

EL DEBS, Mounir K. Concreto pré-moldado: fundamentos e aplicações. 1. ed. São Carlos: EESC-USP, 2000. $441 \mathrm{p}$.

EM DEBATE, A crise dos anos 80 e tendências da nova década". Revista Projeto, n.129, jan./fev. 1990, pp. 143-157.

ESTRUTURA em madeira: três partidos. AU, São Paulo, n. 36, p. 27-33, jun./jul. 1991.

FABRÍCIO, Marcio M. Processos construtivos flexíveis: projeto da produção. São Carlos, 1996. Dissertação (Mestrado). Escola de Engenharia de São Carlos, Universidade de São Paulo.

FERREIRA, Avany de Francisco; MELLO, Mirela Geiger de (orgs). Arquitetura Escolar Paulista - Estruturas pré-fabricadas. São Paulo, FDE - Diretoria de Obras e Serviços, 2006. 336 p. 
FERREIRA FILHO, Efren de Moura. Construção com solo-cimento. Artigo técnico. Ceplac. Disponível em: <http://www.ceplac.gov.br/radar/Artigos/artigo7.htm> Acesso em: 27 jul. 2007.

FERRO, Sérgio. o canteiro e o desenho. São Paulo: Ed. Projeto, 1982.

. Sérgio Ferro - Arquitetura e trabalho livre. Org. Pedro Fiori Arantes. São Paulo: Cosac Naify, 2006.

FRACASTEL, Pierre. Arte e técnica nos séculos XIX e XX. Lisboa: Livros do Brasil, 1963. 346p.

FUJIOKA, Paulo Y. Princípios da arquitetura organicista de Frank Lloyd Wright e suas influências na srquitetura moderna paulistana. São Paulo, 2003. Tese (Doutorado). Universidade de São Paulo. Faculdade de Arquitetura e Urbanismo. $313 \mathrm{p}$.

FUNDAÇÃO PARA O DESENVOLVIMENTO DA EDUCAÇÃO. Ambientes: especificações de edificação escolar de primeiro grau. Fundação para o desenvolvimento da educação. 4. ed. São Paulo: FDE, 1992.

GAMA, Ruy. A tecnologia e o trabalho na história. Nobel/ Edusp. 1987. 239 p.

GIEDION, Sigfried. Espaço, tempo e arquitetura. O desenvolvimento de uma nova tradição. São Paulo: Martins Fontes, 2004, 950 p.

GRAEFF, E. A. Arte e técnica na formação do arquiteto. Fundação Vilanova Artigas, Studio Nobel, 1995, 142p.

GREGOTTI, Vittorio. Território da arquitetura. São Paulo: EDUSP/ Perspectiva, 1975. $191 \mathrm{p}$.

GRILO, Leonardo Melhorato. A integração entre os agentes do processo de produção e o desempenho da indústria da construção de edifícios. In: III Workshop Brasileiro de Gestão do Processo de Projeto. Belo Horizonte. Anais. 27 a 28 de novembro de 2003.

GROPIUS, Walter. Bauhaus: Novarquitetura. 2. ed. São Paulo: Perspectiva, 1974. 223p.

JAQUES, Annie. La carriére de l'architecte aU XIX siècle. Paris: Editions de la Réunion des Musées Nationaux, Paris, 1986.

KIMBELL ART MUSEUM. Disponível em: <http://icar.poliba.it/storiacontempora nea/seminari/suma/SUMA02/img 13.htm> Acesso em: 20 jul. 2007.

KOURY, Ana Paula. Grupo Arquitetura Nova. São Carlos, 1999. Dissertação (Mestrado). Universidade de São Paulo. EESC - Escola de Engenharia de São Carlos. $139 \mathrm{p}+$ anexos.

- Grupo Arquitetura Nova. São Paulo: Edusp, 2003.

LEMOS, Carlos Alberto Cerqueira. O Modernismo Arquitetônico em São Paulo. III Seminário Docomomo, Estado de São Paulo, 2005. Disponível em: <wWw.vitruvius.com.br/.../arq065/arq065_01.asp>. Acesso em: 30 jul. 2007. 
Referências

LIMA, Daniela Colin. Entrevista com Sérgio Ferro. Disponível em: <http://www.vitruvius.com.br/entrevista/ferro/ferro.asp> Acesso em: 20 jun. 2007.

LOPES, João Marcos de Almeida. Em memória das mãos: o Desencantamento da Técnica na Arquitetura e no Urbanismo. São Carlos, 2006. Tese (Doutorado). Universidade Federal de São Carlos. 350 p.

LUCINI, Hugo C. Manual técnico de modulação de vãos de esquadrias. São Paulo: Pini, 2001. 101p.

MAHFUZ, Edson. Nada Provém do Nada. A produção da arquitetura como transformação de conhecimento. Projeto, n. 69, nov. 1984, pp. 89-95.

MARTINS, Alberto. Ita: da pedra à madeira serrada. In: AFLALO, Marcelo (Org.). Madeira como estrutura a história da lta. São Paulo: Paralaxe, 2005, 152p.

MARCOS ACAYABA ARQUITETOS (2007). Disponível em: <http://www.marcosacayaba.arq.br>. Acesso em 25 jul. 2007.

MARCOS Acayaba: a economia dos custos. Módulo, São Paulo, n. 71, p. 42-4, jun. 1982.

MARTUCCl, Ricardo. Projeto tecnológico para edificações habitacionais: Utopia ou Desafio? São Paulo, 1990. Tese (Doutorado). Universidade de São Paulo. Faculdade de Arquitetura e Urbanismo. 438p.

MASCARÓ, Lúcia E. A. F. Inovação tecnológica e produção arquitetônica. São Paulo, 1990a. Tese (Doutorado). Universidade de São Paulo. FAU - Faculdade de Arquitetura e Urbanismo. 316 p.

MASCARÓ, Lúcia E. A. F., (Coord.); Victor Saúl Pelli . Tecnologia \& Arquitetura. São Paulo: Nobel, 1990b. 136 p.

MASCARÓ, Ruán Luis. Custo das decisões arquitetônicas. São Paulo: Nobel, 1985. 100p.

MAZZEl, Rebecca. Still standing - Chicago duo does up Detroit in a definitive new book. 30 nov. 2005. Disponível em: < http://www.metrotimes.com /editorial/story.asp?id=8550> Acesso em: 20 jul. 2007.

METODOLOGIAS e conhecimento tecnológico: instrumentos de trabalho. II Inquérito. Projeto, n. 42, jul./ ago. 82, p. 59-60.

MUMFORD, Lewis. Arte y tecnica. 3 ed. Buenos Aires: Nueva Vision, 1961.

NAS TRILHAS do pensamento crítico. José Wolf e Éride Moura (coord.). $\underline{\text { UU, }}$ ago./ set. 1993, p. 77-81.

NOGUEIRA, Maria Cristina J. A.; NOGUEIRA, José S.; LAHR, Francisco Antônio R. Avaliação da Itaúba e do Angelim Pedra para uso na construção civil. Comunicação Científica. Revista Agricultura Tropical, Cuiabá, v. 5, n.1, Dez. 2001. Disponível em: <http://www.ufmt.br/agtrop/> - Acesso em: 12 mar. 2007.

OLIVEIRA, Ana Rosa de. Entrevista com Lúcio Costa. 1992. Disponível em: <http://www.vitruvius.com.br/entrevista/luciocosta/luciocosta_3.asp>. Acesso em: 21 jun. 2007. 
PAINEL Wall Eternit. Disponível em: < http://www.eternit.com.br/produtos/ painelwall/index.php?acao3_cod0=430268a34533834333b0582d2d159b04> Acesso em: 04 jun. 2007.

PASSAGLIA, LUiz A. P. Influência do movimento da arquitetura moderna no Brasil na concepção de desenvolvimento e na formação do arquiteto. São Paulo, 1991. Tese (Doutorado). Universidade de São Paulo. EESC - Escola de Engenharia de São Carlos. 2v.

PAVILLON Pindorama. L'Architecture d'Aujourd'hui, Paris, n. 251, p. 26-7, jun. 1987.

PICON, A. Towards a history of technological thought. In: FOX, R. (Ed.) Technological change - methods and themes in the history of technology. Londres: Harwood Academic, 1996. p. 37-49.

PRANCHETA. Entrevista com Marcos Acayaba. Entrevistadora: Lívia Álvares Pedreira. AU, ago. 1986, pp.57-60.

JARA, José L. F. de la; MENDOZA, Christian A. Planeamiento de la edificación. Capítulo 4. In: PIQUÉ, Javier (Coord.). Manual de diseño para maderas del Grupo Andino. 4. ed. Lima - Peru: Junta Del Acuerdo de Catagena, 1984.

PORTO, Severiano Mario. Obra pioneira. Entrevistador: Vânia Silva. AU, n. 119, p. 48-50, fev. 2004.

ROSLYN Oxley9 Gallery. Harry Seidler - Convent of La Tourette. Disponível em: < http://www.roslynoxley9.com.au/artists/65/Harry_Seidler/302/25128/> Acesso em: 20 jul. 2007.

SANTORO, Francesco. La "curiositá" strutturale di Marcos Acayaba, architetto brasiliano. L'Architettura, Roma, n. 517/518, p. 652-76, nov/dez 1998.

SEGAWA, Hugo; SANTOS, Cecilia Rodrigues dos e ZEIN, Ruth Verde (Orgs.) et. al. Arquiteturas no Brasil: anos 80. São Paulo: Projeto, 1988.

SEGAWA, Hugo. As vertentes da invenção arquitetônica: arquiteturas da lógica, da beleza, onde nada sobra e nada falta. Projeto, São Paulo, n. 198, p. 28-29, jul. 1996.

Arquiteturas no Brasil 1900-1990. São Paulo, Edusp, 1999.

SEGNINI Jr., Francisco. A prática profissional de arquiteto em discussão. (Depoimento de 202 arquitetos de 1985 a 2000) São Paulo, 2002. Tese (Doutorado). Universidade de São Paulo. FAU - Faculdade de Arquitetura e Urbanismo. $238 \mathrm{p}$.

SERAPIÃO, Fernando. Partido arquitetônico encontra definição entre o módulo e a topografia. ProjetoDesign, ArcoWeb . Disponível em: <http://www.arco web.com.br/arquitetura/arquitetura667.asp>. Acesso em 25 set. 2006.

SILVA, Diogo Oliveira. Cordas, cabos e outros objetos dependurados. Gazeta da Física, vol. 26, fasc. 2-3, jul. 2003.2 Disponível em: <http://nautilus.fis.uc.pt/gazeta/>. Acesso em: 23 mar. 2007.

SOUZA JR., Hélio Olga. Usa-se madeira quando o material é pertinente. Esse é o pressuposto de uma boa arquitetura. Entrevista com Hélio Olga de Souza Jr. 
Entrevistadores: Adilson Melendez e Fernando Serapião. Projeto, n. 254, fev. 2002.

Hélio Olga de Souza Jr.: entrevista. Entrevistador: Tatiana Midori Nakanishi. São Paulo. 1 CD-ROM. 23 mar. 2007a.

Dúvidas Vila Butantã [mensagem pessoal]. Mensagem recebida por <tati_nakanishi@yahoo.com>em jul.2007b.

TRUJILLO, Jorge Hernán Salazar. Os dois lados da moeda. Trad. Fábio Lopes de Souza Santos. Revista Risco, n. 4, fev. 2006, p. 9-12. Disponível em: <http://www.risco.eesc.usp.br/Risco4-pdf/art_2_risco4.pdf>. Acesso em: 25 jun. 2007.

VARGAS, Milton. A Tecnologia no Brasil. In: MOTOTYAMA, Shozo; FERRI, Mário G. História das ciências no Brasil. São Paulo: EDUSP/EPU/CNPq, 1979. Vol. 1.

VARGAS, Milton (org.). História da técnica e da tecnologia no Brasil. São Paulo: Ed. Unesp, 1994.

VASCONCELOS, Augusto Carlos de. O concreto no Brasil. Recordes Realizações - História. São Paulo: Pini, vol. 1, 2 e 3, $2^{a}$ ed., 1992.

VERMICULITA isolantes termo-acústicos (2007). Disponível em: <http://www.vermiculita.ind.br>. Acesso em: 27 mar. 2007.

ZEVI, Bruno. Saber ver a arquitetura. São Paulo: Martins Fontes, 1994. 
Anexo A

\section{ANEXO A}

Transcreve-se a baixo um texto escrito pelo arquiteto sobre sua metodologia de trabalho e sua postura projetual, que foi apresentado na Bienal Internacional do Chile, em Santiago, em 1997 e é parte de sua tese de doutoramento, "Projeto, Pesquisa, Construção", de 2004:

Estudei na Faculdade de Arquitetura e Urbanismo da Universidade de São Paulo entre 1964-1969. A Escola era então relativamente nova: fazia apenas quatorze anos que tinha se desmembrado da Escola Politécnica. Até então, em São Paulo, o que havia era um curso que formava Engenheiros-Arquitetos na Escola Politécnica. Em 1948, a Faculdade de Arquitetura começou a funcionar separada da Escola Politécnica. Evidentemente, nos primeiros anos a escola estava ainda muito impregnada de um espírito politécnico. A maioria dos professores vinha da Escola Politécnica e alguns da Escola de Filosofia. Havia na escola uma grande ênfase em questões técnicas. Tínhamos muitos professores engenheiros e, mesmo entre os arquitetos, vários tinham formação politécnica. Nosso professor mais importante, João Vilanova Artigas, era engenheiro-arquiteto formado pela Escola Politécnica.

As questões técnicas, de estrutura, dos processos de produção e da industrialização da construção eram muito importantes e frequentemente orientavam nossos projetos no atelier. A proposta da Faculdade era de formar profissionais que se integrassem no processo de produção.

Minha experiência, com a formação que recebi na escola, com trinta anos de prática profissional, fez com que eu viesse a pensar o arquiteto como o primeiro operário que participa do 
processo da obra. A sociedade identifica a necessidade de uma edificação qualquer, elabora um programa e o encaminha ao primeiro operário, o arquiteto. Ao arquiteto cabe a tarefa inicial, a concepção do projeto, instrumento necessário para a realização da obra. Como o primeiro operário, nas suas operações, na prancheta $u$ no computador, o arquiteto deve considerar cuidadosamente as operações que seus companheiros, os outros operários, vão realizar depois. Da mesma forma, além de considerar todas as tarefas a realizar na obra, deve avaliar criteriosamente todo material que não seja absoltamente indispensável para a realização da obra. Todo material deve trabalhar na plenitude de suas características.

Nos meus projetos, em paralelo à interpretação da encomenda do cliente, transcrita no programa de necessidades, procuro inicialmente identificar e analisar as características locais, a acessibilidade, o entorno, a paisagem, o clima, enfim todas as condicionantes geográficas; e também as condicionantes tecnológicas como a disponibilidade de fornecimento de materiais e a qualidade da mão de obra. Procuro, a partir da análise conjunta de todas as condicionantes, deduzir qual a melhor estratégia para a realização da obra. Assumo, então, a estratégia de obra, onde o processo de produção é fundamental, como uma referência, como uma bússola, para orientar a concepção e desenvolvimento do projeto.

Dentro dessa filosofia de trabalho, tenho desenvolvido projetos onde a preocupação com a construção e seus processos de produção são determinantes. Tenho procurado aproveitar as oportunidades profissionais para realizar ensaios, para desenvolver novas técnicas e novos conceitos. São projetos com caráter de pesquisa.

Pra mim, projeto sempre implica em pesquisa, complementada e aferida na construção (ACAYABA, 2004, v.1, p. 21-22). 